UNIVERSIDADE DE SÃO PAULO - USP

FACULDADE DE FILOSOFIA LETRAS E CIÊNCIAS HUMANAS - FFLCH PROGRAMA DE PÓS-GRADUAÇÃO EM GEOGRAFIA HUMANA DEPARTAMENTO DE GEOGRAFIA

DOUTORADO EM GEOGRAFIA HUMANA

\title{
GEOGRAFIA HISTÓRICA, DISCURSOS ESPACIAIS E CONSTRUÇÃO TERRITORIAL EM SANTA CATARINA
}

\author{
ORIENTADORES: \\ Prof. Dr. Antonio Carlos Robert Moraes (in memoriam) \\ Prof. Dr. Manoel Fernandes de Sousa Neto
}

André Souza Martinello

São Paulo

2016

Versão corrigida 
Autorizo a reprodução e divulgação total ou parcial deste trabalho, por qualquer meio convencional ou eletrônico, para fins de estudo e pesquisa, desde que citada a fonte.

Catalogação na Publicação

Serviço de Biblioteca e Documentação

Faculdade de Filosofia, Letras e Ciências Humanas da Universidade de São Paulo $\mathrm{Mg}$

MARTINELLO, André Souza Martinello GEOGRAFIA HISTÓRICA, DISCURSOS ESPACIAIS e CONSTRUÇÃO TERRITORIAL EM SANTA CATARINA / André Souza Martinello MARTINELLO ; orientador Manoel Fernandes de Sousa Neto SOUSA NETO. - São Paulo, 2016. $243 \mathrm{f}$.

Tese (Doutorado)- Faculdade de Filosofia, Letras e Ciências Humanas da Universidade de São Paulo. Departamento de Geografia. Área de concentração: Geografia Humana.

1. Geografia Histórica. 2. Construção de/do Território. 3. Santa Catarina. 4. Território catarinense (1738-1946) . 5. História Espacial e discursos na conformação de espaços em Santa Catarina. - I. SOUSA NETO, Manoel Fernandes de Sousa Neto, orient. II. Título. 
Universidade de São Paulo

\section{ATA DE DEFESA}

Aluno: 8136 - $7771699-1 /$ Página 1 de 1

ata de defesa pública de Tese do(a) Senhor(a) André Souza Martinello no Programa: Geografia (Geografia Humana), do(a) Faculdade de Filosofia, Letras e Ciências Humanas da Universidade de São Paulo.

Aos 15 dias do mês de dezembro de 2015, no(a) Sala de Concursos realizou-se a Defesa da Tese do(a) Senhor(a) André Souza Martinello, apresentada para a obtenção do título de Doutor intitulada:

"Geografia histórica, discursos espaciais e construção territorial em Santa Catarina"

Após declarada aberta a sessão, o(a) Sr(a) Presidente passa a palavra ao candidato para exposição e a seguir aos examinadores para as devidas arguições que se desenvolvem nos termos regimentais. Em seguida, a Comissão Julgadora proclama o resultado:

$\begin{array}{llll}\text { Nome dos Participantes da Banca } & \text { Função } & \text { Sigla da CPG } & \text { Resultado } \\ \text { Manoel Fernandes de Sousa Neto } & \text { Presidente } & \text { FFLCH - USP } & \text { Aprovado } \\ \text { Iris Kantor } & \text { Titular } & \text { FFLCH - USP } & \text { Aprovado } \\ \text { Fabio Betioli Contel } & \text { Titular } & \text { FFLCH - USP } & \text { Aprovado } \\ \text { Nazareno José de Campos } & \text { Titular } & \text { UFSC - Externo } & \text { Aprovado } \\ \text { Beatriz Piccolotto Siqueira Bueno } & \text { Titular } & \text { FAU - USP } & \text { Aprovado }\end{array}$

Resultado Finall: Aprovado

\section{Parecer da Comissão Julgadora *}

Ressaltamos a qualidade e a originalidade da investigação e sua contribuição à formação territorial brasileira, atlântica e em especial de Santa Catarina. Recomendamos a sua publicação.

Eu, Daiane Neres da Silva Laiane Neres da com os(as) Senhores(as) examinadores. São Paulo, aos 15 dias do mês de dezembro de 2015.
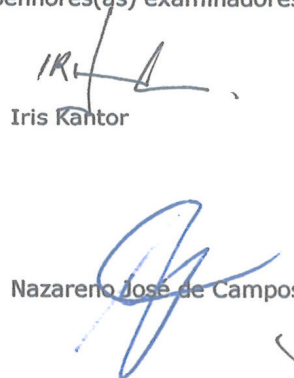

\section{$\sqrt{2}$}
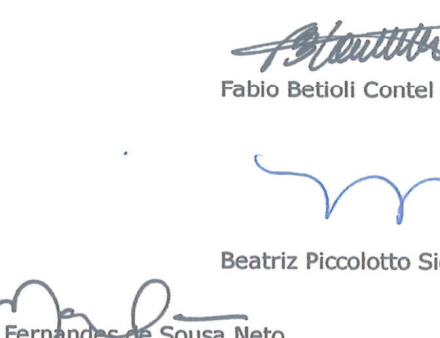

Fabio Betioli Contel

Mresidente

* Obs: Se o candidato for reprovado por algum dos membros, o preenchimento do parecer é obrigatório

A defesa foi homologada pela Comissão de Pós-Graduação em $15 / 12,2015$ e, portanto, o(a) aluno(a) faz jus ao título de Doutor em Ciências obtido no Programa Geografia (Geografia Humana) - Área de concentração: Geografia Humana.

Pleseleedecente da comissão de Pós-Grad Presiciente da Comissão de Pós-Graduação FFLCH-USP

\section{SPG.FFLCH.USP}

CONFERE COM O ORIGINAL

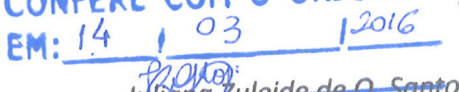
Serviço de Pós-Graduação № Func. 8471651 


\author{
Universidade de São Paulo - USP \\ Faculdade de Filosofia Letras e Ciências Humanas - FFLCH \\ Departamento de Geografia \\ Programa de Pós-Graduação em Geografia Humana \\ Nível: doutorado
}

\title{
GEOGRAFIA HISTÓRICA, DISCURSOS ESPACIAIS E CONSTRUÇÃO TERRITORIAL \\ EM SANTA CATARINA
}

\begin{abstract}
Dedico a presente tese:
Para todas e todos estudantes que têm me feito professor. As minhas mestras e aos meus mestres, professoras-professores; mentoras e mentores que me inspiram nos caminhos da educação e do aprimoramento. Aos professores da familia do lado do pai e da mãe.
\end{abstract} Aos meus pais, que em certa altura de suas vidas graduaram-se professores e exerceram magistério.

Doutorando: André Souza Martinello 


\section{AGRADECIMENTOS}

O tempo de ingresso no doutorado até a realização final da tese e o ato de discuti-la com avaliadores levou aproximadamente quatro anos, entre 2011 e 2015 (quando da defesa). Durante esses mais de quatro anos, certamente é quase impossível não esquecer, deixar passar ou perder de registrar algum agradecimento. Por eventuais falhas e principalmente pela consciência de que não conseguirei nomear justamente todas as instituições e pessoas, primeiro registro um obrigado mais genérico e geral para quem de alguma forma ficou sabendo, acompanhou, me viu e vivemos de certa maneira o tempo de elaboração dessa tese e da busca do doutoramento. Meu obrigado para àqueles, que por falha minha, eventualmente não estejam aqui registrado ou explicitado em nome. Foram vividos esses anos em diferentes lugares: vindo de Florianópolis, morei mais de um ano em São Paulo, depois, em 2013 retornei para Santa Catarina. De Florianópolis fui para Blumenau em 2014 e ali se deu a redação final do último ano. Além de ter feito pesquisa em arquivos no Rio de Janeiro, Curitiba, Florianópolis morei em lugares diferentes e contraí dívidas e gratidão a quem ajudou. Se não mencionei todos nomes, reforço o obrigado (as pessoas sabem quem são).

A possibilidade de ingressar no doutorado em 2011 e ter remuneração com bolsa a partir de setembro de 2012 só se concretizou pelo apoio material e financeiro do "paitrocínio". Assim como, todo apoio também material e econômico de viver em "casa de mãe." Grato ao meu pai, por completo e irrestrita presença e gigante apoio: Obrigado meu pai, sem você eu não saberia como teria chego nas condições que foram sendo dadas. Foi fundamental toda a super disposição paterna. Minha mãe também: porto de acolhida e total, completo e irrestrito apoio, devo muito agradecer. Ter em vocês como parte importante dessa dedicação da tese; ela também é muito fruto dos investimentos, na crença e presença de vocês.

Ao governo federal brasileiro: preciso registrar o formidável apoio da bolsa de doutoramento pela agência de Capacitação de Pessoal de Ensino Superior, na ótima bolsa CAPES de doutorado que recebi entre 2012 e 2015: registro esse importante obrigado.

Ao Professor Antonio Carlos Robert Moraes (im memoriam), conhecido carinhosamente como Tonico, me teve como seu orientando; e aprovou meu ingresso no doutorado em Geografia Humana da USP. Tonico partiu antes da defesa final, conseguiu ler e orientar até uns 2 capítulos quando da qualificação. Fez sua passagem, mas também nos deixou a lição de garra, persistência e do não desistir. Tonico viveu e reviveu, reergueuse para deixar dito que se capoeira um dia cai, cai bem. Certamente que encobertos pela sensação de que havia ainda muito para ele fazer, mas muito Tonico fez.

Professor Manoel Fernandes de Sousa Neto assumiu em todos os momentos com rigor de gente de verdade uma orientação repleta de camaradagens, questionamentos e que fez com que a tese chegasse ao seu fim e a trajetória tivesse sido completa e completada. Esse é uma tese de dois orientadores, o da velha guarda que partiu e a nova vanguarda que Manoel representa em sua geração. No processo da perda de um orientador que completou seu ciclo de vida, houve o encontro extremamente bem resolvido e aberto: - Manoel fez a orientação mais sincera que pessoas em luto poderiam fazer: tornou nosso encontro de doutorando e orientador um trabalho intelectual. Leve, sereno e imaginativo, agradeço ao Prof. Manoel essa transição de mais de um ano da orientação das mãos do Tonico para as dele. Com a defesa encerramos um belo ciclo; e uma amizade nasceu: obrigado!

Tanta gente a agradecer e por tantos por quês... e já que foi tão plural o nome plural da pessoa plural: a Clenes, do Geopo - Laboratório de Geografia Política (USP). Obrigado por me alertar na selva de pedra ou, a me ensinar a sobreviver nessa imensa Sampa, naquela grande USP que cheguei acanhado, com medos e muito inseguro. Clenes tem o tom, o 
mapa, a alegria e emprestou a chave do laboratório para que eu pudesse freqüentar e usá-lo (junto com uma declaração regularmente renovada para meu livre acesso ao Geopo, mesmo nos finais de semana). Agradeço sua confiança e camaradagem, Clenes.

Aos colegas da badalada república de moradia: o "Solar (dos Príncipes)"; aprendi muito dessa vivência partilhando uma casa... não foi fácil e também não foi um drama. Era caro, engraçado e uma diversidade nada rotineiramente ordinária. O meio ano que morei nessa republica parece ter sido para mim, a maior experiência utópica e imaginativa que vivi... muita música, muita conversa e muita gente enchendo o saco de todo mundo. Sobrevivi e depois mudei para uma pensão na Vila Indiana (a quem também registro agradecimento pelas amizades em ambos lugares que morei em Sampa em 2012 e 2013).

Muitas pessoas eu preciso agradecer desse processo: o colega Miguel Vieira de Lima; a conterrânea e parceira amiga Maria Helena Lenzi (obrigado pelo diálogo nos momentos de mais apuros e de angustias). A querida corajosa, guerreira e ativa amigona Simone Affonso, a Simoninha: um obrigado pelo afeto e diálogo: mesmo longe é perto!

Preciso mencionar nomes de pessoas de vários cantos, lugares e circunstância como Célia Sakurai (valeu!); Vera Lúcia Nehls Dias (embalou a ideia de pós-graduação desde uns 10 anos atrás já passados....); Prof. João Klug (e toda comunidade amiga do Labimha-ufsc). Quero agradecer parceria de muitos amigos e camaradas, desde Vitor Hugo Bastos Cardoso, passando por Thiago Rodrigo Silva; super camarada Edison Lucas Fabrício; a Sandra Onneing da Silva... aprendi muito com vários colegas de trabalho, estudos e vida universitária.

Pessoas de instituições como UFSC, UDESC, (o PGDR da) UFRGS, contemporâneos de FFLCH da USP, meu obrigado.

Da minha passagem pelo do Itajaí, particularmente Blumenau: esse é o melhor lugar para um nascido itajaiense, mas vivido a infância e pré-adolescência em Guaramirim (SC) ter ido parar... a FURB é uma instituição que me abriu porta para possibilidade de lecionar na graduação e conhecer muitos estudantes. Devo agradecimento para vários colegas da instituição. Prof. Ivo M. Theis conseguiu ler uma parte do primeiro capítulo (a quem agradeço). Colega Luciana B. do departamento de ciências sociais também dialogou se dispôs em ler, agradeço. A partir do nome do atual diretor do Centro de Ciências Humanas e da Comunicação (CCHC) da FURB, Prof. Celso Kramer, gostaria de agradecer todos os demais colegas professores seja do departamento de História e Geografia, seja de outros departamentos como da Educação (via coordenadora Rose Nazário), do Comércio Exterior, do Serviço Social (Prof ${ }^{a}$ Cleide e Maria Salete)... ao excelente grupo de estudos e discussões (e de amigos) do NPDR do PPGDR da FURB.

Obrigado aos estudantes que trocaram ideias e boas conversar. Ao Michel e toda sua classe de História da FURB ano de entrada 2014-1: - obrigado por me iniciarem no mundo da docência na universidade. Agradeço à Larissa que me ajudou a colocar as imagens do Pequeno Príncipe no correr da apresentação inicial. Aos colegas da Uniasselvi (em Indaial-SC), mesmo tendo sido rápido o contato e passagem ali, agradeço tod@s.

São muitos obrigados, dívidas e agradecimentos: faço aqui de maneira genérica, mais uma vez, como um pedido de desculpas pelas omissões e esquecimentos. No fundo, as pessoas que de alguma forma ajudaram sabem quem são; eu também sei delas e ao encontrá-las de alguma forma as agradeci ou agradecerei. Àquelas que chegarem aqui e com o passar dos olhos virem uma parte do meu trabalho, também podem e devem se sentir parte dele. Aos meus irmãos, obrigado por acreditarem em mim.

Para toda minha família, para todos meus colegas, para todos os meus amigos, para todos meus professores e companheiros:

Eu não vim sozinho e não vou sozinho, eu só posso dizer meu muito obrigado pela partilhar de irmos e das trocas no caminho. 


\section{RESUMO}

A presente pesquisa busca mapear alguns momentos relevantes, circunstâncias e situações marcantes na constituição histórica de "um espaço catarinense" e suas territorializações. Passando pelo período colonial: quando rota de viajantes no circuito marítimo a elegem como um ponto de parada e em seguida, pela criação da capitania subalterna (1738) da Ilha de Santa Catarina - toponímia que nomeia posteriormente todo o Estado - e pela complexidade da anexação do Planalto (1820). Defende uma ideia, a tese de como a localização da capital e sua sede administrativa é resultado de arranjos do período colonial, sendo herança que resistiu ao tempo (mais do que a conjuntura que a tornou lócus de poder) e permaneceu às mudanças. A sede da escolha da capital refletindo resultado e decisão de uma territorialidade militar. Já no final do século XIX, nos primeiros anos da República, discutia-se a Questão Missões e, na presente pesquisa, as relações do território brasileiro nesse período são problematizadas no segundo capítulo, quando é discutido as repercussões do fim do litígio (1895) na fronteira Oeste catarinense. Trata-se também dos usos sociais dessa querela e das representações do espaço: seja para usos e conquistas individuais, seja pelo movimento republicano, desejando encontrar símbolos que se opusessem a monarquia (do segundo império), validando a tese do Brasil na acepção espacializante. Presente também na construção de Santa Catarina, a ideia do espaço, antes da sociedade, como gerador de agregação ou indutor de coesão. Essa pesquisa discute um País em que heróis territoriais são colocados em (ou ocupam) posições relevantes na representação da nacionalidade, costumando atribuir-lhes poderes, por resguardarem áreas e manterem ou expandirem fundos territoriais. Casos como Barão do Rio Branco, Barão de Capanema, Emil Odebrecht, e num caso paradigmático, governante catarinense representando-se como um bandeirante na Viagem (em 1929) aos sertões de Santa Catarina. Através da análise de espaços e poder, essa investigação defende como a construção territorial catarinense é influenciada por dinâmica colonial, seja pela junção complexa de circuitos e unidades "separadas" do litoral e planalto com anexação de Lages (1820), seja como relação maior no contexto de disputas Ibero-Americanas. Um interior lentamente integrado reflete, por exemplo, quando em 1943 a União encampa uma área desanexando o extremo Oeste e até 1946, permanece submetido à governança federal, no Território do Iguaçu. Essa área que cobre tal Território, havia passado pelo litígio com Argentina; tendo sido também contestado entre o Paraná e Santa Catarina, e para a qual um governante "leva" instituições estaduais catarinenses; é desmembrado por ser considerado em abandono. É atribuída à área, quando da criação do Território Federal do Iguaçu, a necessidade de maior e mais rápida integração ao Brasil (pois faz divisa com país estrangeiro). Embora se dizia da urgência da integração, três anos após é reincorporada aos seus estados de origem, Paraná e Santa Catarina. Enfim, a presente tese trata de discursos, concepções e construções (do espaço catarinense) em que se atribuiu a necessidade de integrar o território, apropriá-lo, para inventá-lo e fazer existir abrangência de uma comunidade catarinense, num espaço entendido como (de) Santa Catarina.

Palavras-chave: Território catarinense; Geografia Histórica; Santa Catarina; Integração; Discurso espacial 


\begin{abstract}
The present research intends to map some relevant periods, circumstances and situations that constitute the history of the space corresponding to Santa Catarina and its territorializations. One advances the colonial period, in which the sea route was the only possible way to move, then the subordinate captaincy (1738) of Santa Catarina Island toponymy that will name the whole state later and, finally, its complex attachment to the Plateau (1820) occurs.We defend the thesis according to which the location of the capital city and its administrative headquarters are consequence of the colonial period, whose heritage resisted the elapsed time (more than the conjuncture which made it the locus of power) and stood amidst all changes.Choosing the capital city as the seat of government reflected the decision made by military territoriality. This reasearch discusses the end of the dispute (1895) in the western border of Santa Catarina, in the first republican years. These are also the social uses of this litigation and of the representations of space, either for individual uses and conquests or for the republican movement, yearning symbols that would impose upon Monarchy and Second Empire; that all validates the thesis that contemplates Brazil under a spacial perspective. In the construction of Santa Catarina, one may consider the idea of space, before the one as a society, generating aggregation or inferring cohesion. Thisresearch discusses this country, in which some territorialheroes are placed in (or occupy) relevant positions representing nationality. Hereupon power is attributed, which protects some areas, maintaining or expanding territorialfunds. Some cases can be mentioned: Baron of Rio Branco, Baron of Capanema, Emil Odebrecht, and the most oustanding of all a governor from Santa Catarina who is represented as a trailblazer in the Voyage (in 1929) inland within the same state. Through the analysis of space and power, this investigation defends how the social construction of Santa Catarina is influenced by colonial dynamics, either because of the complex junction of circuits and "separate" units of the coast and the plateau, by attaching Lages (1820), or because of the relations in the context of the Iberoamerican disputes. The inlands, slowly being integrated reflect, for example, the fact in 1946 when the Federation takes control of an area undoing the attachment of the Far West, which remained submitted to the federal government, in the Territory of Iguaçu. Finally, this thesis deals with some discourses, concepts and constructions (related to the space of Santa Catarina), within which the necessity to integrate this territory, appropriate it, by inventing it, made it exist as a community, in the space understood as (belonging to) Santa Catarina.
\end{abstract}

Keywords: Santa Catarina territory; Historical geography; Santa Catarina; integration; space speech 
"Em nossa época, entretanto, devemos conceber o Estado contemporâneo como uma comunidade humana que, dentro dos limites de determinado território - a noção de território corresponde a um dos elementos essenciais do

Estado - reivindica o monopólio do uso legitimo da violência física."

Max Weber (2004, p.56), Ciência e Política: duas vocações

"De início, o amor pela Geografia me veio pelos caminhos da poesia - da imensa emoção poética que sobe da nossa terra e das suas belezas: dos campos, das matas, dos rios, das montanhas; capões e chapadões, alturas e planuras, ipuêiras e capoeiras, caatingas e restingas, montes e horizontes; do grande corpo, eterno, do Brasil. Tinha que procurar à Geografia, pois." João Guimarães Rosa (20-XII-1945), em discurso de posse na Sociedade Brasileira de Geografia

"As formas geográficas também se apresentam como relação a obedecer e se materializam mediante um conjunto de normas e ou regulações jurídicas, sociais e culturais que não só balizam como causam impactos diferenciados sobre

os lugares e as regiões; as formas de propriedade e de apropriação territorial são dois exemplos mais significativos."

Maurício de Almeida Abreu (2010, p.19), em Geografia Histórica do Rio de Janeiro.

"Nós, os geógrafos éramos, então os proprietários da discrição dos lugares, tarefa que hoje está entregue a mídia, sobretudo à televisão. O mundo entra em nossa casa com os jornais, as rádios, a telinha.

A Geografia perdeu o monopólio da descrição. Ela tem, então, que fazer outra coisa para poder conversar mais com os cientistas sociais". Milton Santos (2000, p.50), em entrevista na obra Território e Sociedade

"A autolocalização do indivíduo no mundo é essencial na formação de sua consciência social." Antonio Carlos Robert Moraes (2002, p.14) em A contribuição social do ensino de Geografia 


\section{SUMÁRIO}

Até que nem tanto geográfico assim. Abrindo um texto com Antoine Saint-Exupéry: convite informal para leitura

Introdução

Geografia Histórica: volver

\section{CAPÍTULO I}

-Bases Para Emergência do Território "Catarinense"

Das disposições para sínteses e abrangências

Territorialidade do Estado-nação (mercado em primeiro lugar, na América) versus

Territórios Sociais, diálogo teórico nas "convivências" tensionadas no Brasil

O Brasil como território. O território como Brasil

Espaço barganba. Política e território, caso da criação da Província do Paraná, 1853

A localização da capital em uma ilha: "rugosidade" e longa duração na relação com a montagem territorial catarinense

E o que é uma rugosidade? Milton, explica. Uma ilha e seus usos: permanências

Baía(s) da ilha: navegar é preciso, parar é necessário. Quando o mar faz a ocasião

Capilariza, Capital. Não capitaliza a Capital? A ponte para a rugosidade vencer ou o uso da ponte para capital acontecer

Territorialidade do navegar, antes da territorialidade militar. Ou, "Uma baía do

Continente, larga e cômoda, que os franceses chamam de 'Bom-port." - Anson

A certidão e a toponímia, Santa Catarina: a ilha que nomeou uma Província/Estado

\section{CAPITULO II}

Alguns Usos da Questão de Palmas e do Litígio Brasil Argentina: Sentidos e Estratégias

Discursivas a um Fundo Territorial

Territórios ambiguos, interesses republicanos?

Câmara/Congresso diz não a Bocaiúva, não à Argentina. Sim, ao Arbitramento

Engenheiro geógrafo cartógrafo e o mapa Questões dos Limites. Emil Odebrecht nas tramas

das representações do espaço cartografado na geo(e)política no Império

A Alemanha que se via desde o Brasil. O Brasil visto com olhar alemão 
Olhando e temendo a vizinhança. Valores da área em litígio: natureza e território

A vitória (foi) dos mapas e do Barão do Rio Branco: trajetórias e contexto do "herói territorial" nacional, por excelência

Do Visconde para o Barão: o sucesso, de pai pra filho

Convencer para manter território: Palmas pertence ao Brasil. Alguns argumentos

CAPITULO III

Um Bandeirante no Último Ano da Década de 20, do Século XX: O caso do Oeste de Santa Catarina e a Viagem do Governador em 1929

(Auto-)constituidores, (desbravadores) do Sertão, não-geógrafos, mas "temáticasgeográficas"

O Bandeirante (brasileiro-germânico) a nacionalizar o Sertão: Adolpho Konder

\section{CAPÍTULO IV}

Território Federal do Iguaçu (1943-1946)

Territórios ao Oeste

Imposições: da criação do território e da extinção do mesmo

Sociedade de Geografia do Rio de Janeiro/SGRJ e a redivisão territorial do País

Sertanismo prévio, prepara a Marcha: contextos para apropriações

Atos simbólicos e atos falhos? Ordinários e extraordinários no Território

Onipresença estadunidense ou uma face da norteamericana no território? 


\section{INDICE DE IMAGENS (MAPAS), GRAVURAS, TABELAS e BOXES}

TÍTULO

PÁGINA

Imagem 1: Áreas com presença de colônias planejadas em caminhos da integração

Tabela 1 Movimentação dos Portos de SC para ano de 1969 por Ferreira (1971)

Imagem 2 Exemplo de Representação cartográfica da Ilha Brasil de Cortesão (1955)

Box 1: Alguns fatores e destaques na constituição de uma territorialidade marítima na ilha

Tabela 2: Ano de instituição de Vilas na hierarquia urbana colonial, Azevedo (1956)

Imagem 3: Carta Topográfica Administrativa da Província de Santa Catharina (1848)

Imagem 4: Área total do Litígio

Imagem 5:Colônias Militares e áreas pretendidas pela Argentina até 1888 e após

Imagem 6: Linha Imaginária acordo Bocaiúva

Box 2: De Blumenau para o Império, do Império para a República

Imagem 7: Emil Odebrecht fazendo trabalhos de topografia e de localização geográfica 122

Imagem 8: Carta resultado da Comissão Mista em que atuou Emil Odebrecht

Imagem 9: Colônias militares brasileira fundadas fora da área de litígio

Imagem 10: A legenda no rodapé da foto, "regionaliza" parte de SC como sertão

Imagem 11:Trajetória da Excursão do Governador Adolpho Konder em 1929

166

Imagens 11 e 12: Capas de publicações de livros de época da expedição ao Oeste

Imagem 13: Estados existentes (alguns "desmembrados") e os Territórios Federais instituídos em setembro/outubro de 1943 pela Lei n ${ }^{\circ} 5.812$ de 13 de setembro

Imagem 14: Administração Território do Iguaçu sem Santa Catarina

Imagem 16 Abrangência do Território Federal do Iguaçu e localização da capital

Reprodução da imagem Cartográfica da área Contestada pelo PR e SC

Imagem: Revista da Sociedade de Geografia do Rio de Janeiro/SGRJ, $2^{\circ}$ sem.1933

Imagem: Menção em jornal O'Estado (Florianópolis) de Ex-Presidente dos EUA, publicidade 


\section{ATÉ QUE NEM TANTO GEOGRÁFICO ASSIM \\ Abrindo um texto com Antoine Saint-Exupéry: convite informal para leitura}

"Voei, por assim dizer, por todo mundo. E a geografia, é claro, me serviu muito". Piloto, antes de encontrar com o Pequeno Príncipe (Antoine de Saint-Exupéry)

Você que chegou até essas palavras, ofereço um convite inicial. Antes de entrar em um texto mais formal, acadêmico, vamos pensar em uma possibilidade mais ampla e até lúdica de convidar e a encorajar que adentre nos capítulos dessa pesquisa? Propus um convite nem tanto geográfico assim... a partir de uma obra de literatura, chamar a refletir sobre apropriações e relações com espaços. Vamos seguir personagem de Antoine de Saint-Exupéry.

O principezinho chegava onde morava um velho debruçado na escrivaninha e atolado em uma floresta de papel de grandes livros. Tratava-se do $6^{\circ}$ planeta daquela jornada que fizera para se instruir. Fora conhecer os demais mundos - alguns aos redores do seu planetinha. Todos os seis planetas por onde andou, eram habitados por homens, pessoas retratadas pelo escritor da história como sendo do gênero masculino. Após ter se despedido da rosa, a flor havia ficado plantada e parece ter sido tratado pelo autor da obra como ela, do gênero feminino, então, ficara lá fixada, enquanto o jovem partiu, literalmente, para outros mundos.

Ele havia passado pelo $1^{\circ}$ lugar, habitado por um rei (como o desenhou em aquarela o autor). Não lhe agradou a forma de vida levada naquele planeta reinado por um único morador, o próprio monarca. Não havendo ninguém além do próprio rei a ser governado, mandado, dirigido... reino, sem súditos é um reino? Principezinho percebeu uma autoridade tão inútil quanto inválida, afinal, estando só, em seu próprio mundo qualquer um seria auto-governo de si mesmo, hierarquias concentradas em um indivíduo só e seu umbigo. A quem reinar se não a si próprio? Coisa que todos que vivem sozinhos em seus próprios reinos fazem, pois, para se autogovernar não é necessário ser rei; sendo rei de si mesmo não se deixa de ser súdito. Reinar sobre si mesmo invalida a existência de rei e de príncipe(zinhos). Em terras em que todos são reis, não parece 
haver súditos. Em terras em que todos são súditos não há valia de reinados. Principezinho sabia disso, ele também vivia em um mundo solitário.

O $2^{\circ}$ planeta em que passara, morada do vaidoso, também pareceu bem esquisito. Nenhuma graça cuidar-se tanto, impecavelmente, querer mostrar-se aos outros e vivendo ali isolado, submerso em seu próprio mundo. Por que e para que existir-se vaidoso se nem havia espelhos? Ali nunca passara alguém; vaidade como fim em si mesma e para auto consumo, utilidade não parece ter. $\mathrm{O}$ vaidoso portava um chapéu para quando fosse aclamado, ao tirá-lo da cabeça faria disso um movimento de agradecimento pela presença de Outro(s). Com a presença do(s) Outro(s) há possibilidades da vaidade existir. Só com o próprio reconhecimento - único - de si mesmo, vaidoso algum se realiza. A vaidade requer o Outro para ultrapassá-lo, competilo, legitimá-lo; vaidade na solidão não gera vaidade. O principezinho achou monótono o movimento de bater palmas para o vaidoso tirar o chapéu da cabeça agradecendo. Fez uma pergunta: "Mas o vaidoso não ouviu. Os vaidosos só ouvem os elogios." (SAINTEXUPÉRY, 2009, p.42). Pediu para ter o prazer de ser admirado, pois vivia a sós. O viajante ali de passagem então afirmou: “- Eu te admiro - disse o principezinho, dando de ombros. Mas de que te serve isso? E o pequeno príncipe foi-se embora." (SAINTEXUPÉRY, 2009, p.42).

No $3^{\circ}$ planeta vivia um bêbado, sendo visita mais curta e a que deixou o protagonista de Antoine de Saint-Exupéry na mais profunda tristeza. Talvez tenha sido essa a personagem que mais ignorou o passageiro príncipe; tiveram um curto diálogo. O bêbado estava acomodado em silêncio em torno de várias garrafas vazias e outras tantas cheias. O principezinho resolveu perguntar o que ele fazia ali naquele planeta. A resposta circulante foi a de que bebia para esquecer a vergonha que sentia por tanto beber; achando essa mais uma escolha estranha, partiu em viagem até o

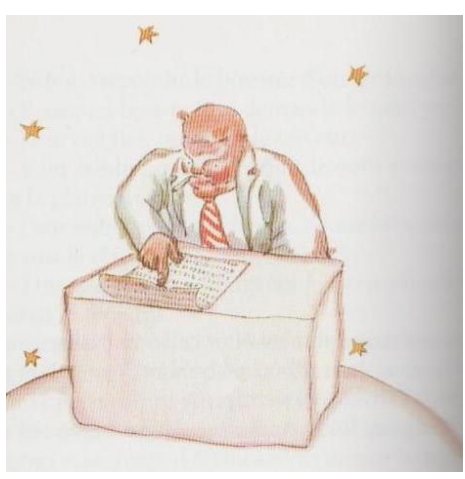
$4^{\text {o }}$ planeta, morada de um empresário.

Sem nem perceber que seu próprio cigarro, o empresário imerso em cálculos, contas, somas, muitos números, não levantou a cabeça e, nem respondeu à 
chegada do príncipe. O empresário havia se auto declarado - dizendo ao forasteiro como sendo um sujeito sério, com um gosto empresarial pela exatidão. Diz ter sido incomodado apenas três vezes naqueles 54 anos em que habitava o planeta. A chegada do príncipe era a terceira das vezes, em que o incomodavam em seu introspectivo trabalho. Foi tenso o diálogo travado; estando o empresário entre os cálculos nas ocupações numéricas. Relata ter tido uma crise de reumatismo por falta de exercício, afirmava em seguida: "Não tenho tempo para passear. Sou um sujeito sério." (SAINTEXUPÉRY, 2009, p.44-45). Com paciência de observador, O Pequeno Príncipe questionou o concentrado empresário, cujo pensamento parecia ser tão circular ou viciado como era do bêbado. Mas a paixão de quem vivia nesse planeta não estava na bebida e sim, no desejo da riqueza:

- E o que fazes com essas estrelas?

- O que faço com elas?

- Sim.

- Nada. Eu as possuo.

- Tu possuis as estrelas?

- Sim.

- Mas eu já vi um rei que...

- Os reis não possuem. Eles "reinam" sobre. É muito diferente.

- E de que te serves possuir as estrelas?

- Serve-me para ser rico.

- E de que te serves ser rico?

- Para comprar outras estrelas, se alguém achar.

(SAINT-EXUPÉRY, 2009, p.45)

E foi se embora mais uma vez o principezinho. Fazia da sua viagem reflexões e, embora, parecendo ser ingênuo pensou consigo mesmo, deveria ser divertido o que fazia o empresário "É bastante poético. Mas sem muita utilidade." (SAINT-EXUPÉRY, 2009, p.46). Criticando a forma de vida levada no planeta do empresário, o príncipe pensava assim: quando cuido no meu planeta, dos vulcões - mesmo extintos - e da flor, sou útil. O pequeno provocara, a respeito da forma do empresário viver naquele planeta e assim questionou: "Mas tu não és útil às estrelas... O empresário abriu a boca, mas não encontrou nenhuma resposta, e o principezinho se foi...”. (SAINT-EXUPÉRY, 2009, p.47).

Ao chegar ao $5^{\circ}$ planeta reparou o observador viajante ser o menor de todos até então visitado. Mas “Tinha o espaço suficiente para um lampião e para um acendedor de lampiões..." (SAINT-EXUPÉRY, 2009, p.47). Era esse, a morada do acendedor e já na chegada, $O$ Pequeno Príncipe não entendia porque um lugar sem casa, sem 
mais gentes - apenas, como demais planetas, um único morador - teria um lampião e, uma pessoa para acendê-lo e apagá-lo. Mesmo achando diferente, o principezinho constatou ser menos tolo do que o rei, o vaidoso, o bêbado e o empresário, pois "Seu trabalho ao menos tem sentido. Quando acende o lampião, é como se fizesse nascer mais uma estrela, ou uma flor. Quando o apaga, porém, faz adormecer a estrela ou a flor. É um belo trabalho. E, sendo belo, tem sua utilidade." (SAINT-EXUPÉRY, 2009, p.47). Mas ali também havia um problema. Um tal regulamento fazia com que o acendedor devesse apagar e acender insistentemente o único lampião. Esse constante acender e apagar se devia, pelo fato do planeta ter passado a girar mais rápido, e para piorar, sem o estatuto haver acompanhado a mudança de aceleração daquele planeta, fazendo com que todo movimento do dia e noite regulasse completamente o que passava ser o único afazer do acendedor. Anteriormente, dizia o acendedor, apagava de manhã e acendia à noite, tendo o dia para descansar e a noite inteira para dormir. Com seu planeta girando cada vez mais rápido, o intervalo da intercalação entre noite e dia passou a ser frenético e a regra de como deveria funcionar o lampião continuava a mesma de quando o planeta girava mais lentamente: de noite acendê-lo, de dia apagá-lo. Agora, a cada um minuto ele fazia essa função e a desfazia no minuto seguinte.

O principezinho gostou do acendedor, antes de ir embora e lamentando, suspirou pensando ser o único com quem poderia ter feito amizade, mas sendo um planeta bem pequeno não haveria lugar para dois. Respeitou-o porquê o viu como fiel ao regulamento (portanto, cumprindo um acordo). Mas também se identificou, pois ele - o próprio principezinho - recuava sua cadeira, lá no seu planeta, fazendo provocar ele próprio o pôr do sol e, indicara ao acendedor, fazer o mesmo. Sugeria o príncipe ao acendedor: sendo o planeta pequeno poderia em três passos contorná-lo e, andando bem lentamente iria ficar sempre com sol, retardando à noite, assim, o dia poderia durar o tempo que ele quisesse usando de uma lenta caminhada. Mas o acendedor o surpreendeu com o oposto quando afirmou:

- Isso não adianta muito - disse o acendedor. - $\mathrm{O}$ que eu gosto mais na vida é dormir.

- Então não há solução - disse o príncipe.

- Não há solução - disse o acendedor. - Bom dia.

E apagou o lampião.

(SAINT-EXUPÉRY, 2009, p.50).

O jovem partiu e continuou suas reflexões fazendo um balanço mental dos cinco planetas e personagens com quem interagiu. Prosseguiu viagem e antes de alcançar o $6^{\circ}$ 
planeta matutou: "Esse aí", pensando sobre o acendedor em relação aos demais que conheceu, nos outros planetas, "seria desprezado por todos os outros, o rei, o vaidoso, o beberrão, o empresário. No entanto, é o único que não me parece ridículo. Talvez porque é o único que se ocupa de outra coisa que não seja ele próprio." (SAINTEXUPÉRY, 2009, p.50).

Chegando ao $6^{\circ}$ planeta, estava agora em área dez vezes maior que os demais cinco planetas em que passara. Quem falou primeiro dessa vez foi o morador dali.

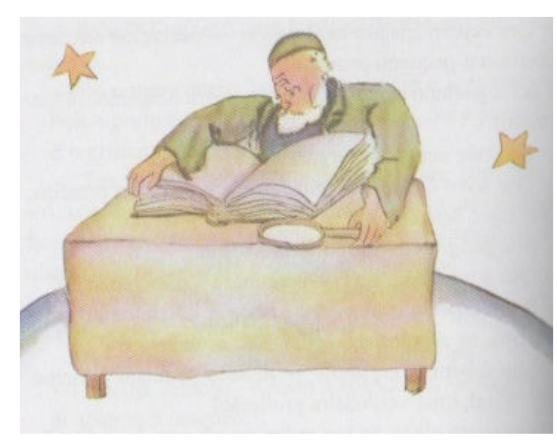

Habitado por um velho escritor de enormes livros exclamando a quem chegara: “- Ora vejam! Eis um explorador! - exclamou ele, logo que avistou o pequeno príncipe." (SAINT-EXUPÉRY, 2009, p.51). Sentou junto da mesa de trabalho daquele senhor, estava ofegante de tantas viagens. A primeira pergunta também veio daquele que portava livros, questionando o viajante de onde ele vinha. Mas a curiosidade juvenil ou a petulância do principezinho o fazia perguntar, antes de responder ao ancião dos livros:

- Que faz o senhor aqui?

- Sou geógrafo - respondeu o velho.

- Que é um geógrafo? Perguntou o principezinho.

- É um especialista que sabe onde se encontram os mares, os rios, as cidades, as montanhas, os desertos.

- Isso é bem interessante - disse o pequeno príncipe.

- Eis, afinal, uma verdadeira profissão!

E lançou um olhar, ao seu redor, no planeta do geógrafo. Nunca havia visto planeta tão grandioso.

- O seu planeta é muito bonito. Há oceanos nele?

- Não sei te dizer - disse o geógrafo.

- Ah! (O principezinho estava decepcionado.) E montanhas?

- Não sei te dizer - disse o geógrafo.

- E cidades, e rios, e desertos?

- Também não sei te dizer - disse o geógrafo pela terceira vez.

- Mas o senhor é geógrafo!

- É verdade - disse o geógrafo. - Mas não sou explorador. Faltam-me exploradores!

(SAINT-EXUPÉRY, 2009, p.51).

Aquele especialista das informações de onde se encontram os mares, as montanhas, os morros, os desertos e as cidades, sabia aonde os encontrar dentro de livros, apenas. Tratava-se de um compilador de gabinete, pouco importava em qual planeta morava para fazer o que fazia. Sabia muito pouco de onde vivia, a morada das suas informações estava dentro dos textos que os tratava como sagrados. Fazia de um 
tipo de reunião de informações, denominando-as de Geografia, sua mais completa alienação do que o cercava. ${ }^{1}$ Descritor de tantos conceitos, organizador de verbetes de alguns elementos da natureza, contraditoriamente tão interessado e curioso. Segundo a descrição do texto e, aparência dos cabelos e barba branca do desenho em aquarela feito por Antoine de Saint-Exupéry (2009, p.52), possuía uma idade avançada e com ela acumulado muitas informações ao longo da vida, mas limitado no saber de tanto e de tudo, pelos escritos que cabem em livros e relatos de exploradores. Nunca ele próprio um peripatético, nem viajante.

Por mais intrigado que estivesse por perceber um tipo de saber ambíguo, o jovenzinho resolveu pedir indicação ao geógrafo. Mesmo que àquele senhor não se visse como um explorador e, por isso, não vivenciado a experiência direta de ter caminhado ou ido aos lugares pessoalmente, nem visto com seus próprios olhos o planeta em que estava inserido, afinal, vivia entre as páginas de longos livros; mas, talvez, ele poderia, mesmo assim, dar alguma sugestão de planetas a percorrer e a lugares a conhecer. Desde que não fossem perguntas a respeito ali do seu planeta, pois, enfim, nunca havia explorado e ele tinha muito pouco a dizer, já notara o viajante. Como se novamente questionando a função desse tipo de Geografia, o jovenzinho demandou-lhe: “- Qual planeta me aconselha a visitar? - perguntou ele. - A Terra respondeu o geógrafo. - Goza de boa reputação...” (SAINT-EXUPÉRY, 2009, p.54).

Dirigi uma espécie de concepções sobre alguns planetas, nos passos da trajetória percorrida pelo pequeno príncipe até aqui. Conduzindo formas de representações de vidas em planetas, de uma narrativa inventada pelo autor Antoine de Saint-Exupéry. Não o fiz com intenção de apontar alguma possibilidade de reflexão mais profunda e uso da literatura em discussão ou pesquisa de Geografia Humana, macro-campo no qual se insere a presente tese de doutorado. Também não propus discutir como os textos criados intencionalmente como ficção literária, possibilitariam problematizar interações entre pessoas imersas em territórios diferentes e que, acredito, há, inclusive, necessidade de apontar etnocentrismos dentro de algumas posições ou reflexões do principezinho, a começar pela: a) forma de nomear a personagem e sua corporeidade (um príncipe que se

\footnotetext{
${ }^{1}$ Como não lembrar, a famosa frase de Milton Santos (2008, p.328) no livro A natureza do espaço, na qual considerou sobre alienação: "Quando um homem se defronta com um espaço que não ajudou a criar, cuja história desconhece, cuja memória lhe é estranha, esse lugar é sede de uma vigorosa alienação."
} 
não branco, mas de cabelos loiro/galego) e b) sua constante busca de comparação ou legitimação dos Outros com base na vida levada no seu planetinha de origem. ${ }^{2}$

Comecei por recortar trechos desse romance de relevante capilaridade na literatura internacional/mundial com intenção de aqui discutir algumas formas de independente de serem discursivas - apropriação de terras, mesmo que tenha se passado metaforicamente fora da Terra. Se fossemos proceder dando estatuto de verdade para essa obra de ficção, diríamos que até mesmo "não em Terra" todas as personagens e planetas que percorreu o príncipe estavam espacializados, no sentido de enraizados em algum território ou brincando com as palavras, todos eram planetarizados. Só quando o pequeno se desloca entre os planetas não nos é informado à maneira como o faz. Evidentemente trata-se do território da livre imaginação, forma de abordagem literária que não estou me vinculando nesse presente texto, embora tenha utilizado de trechos do romance, quando entendi como úteis para dar sentido à narrativa que construí.

Interessei trazer da narrativa, das vivências sob aqueles planetas percorridos pelo príncipe pequeno, as formas de tratamento de espaços, em que o autor nos apresenta personagens em interação e de certa forma, imersos. $\mathrm{O}$ único a, e com o perdão do neologismo, se "desplanetizar" e arriscar-se a ser - para usar uma expressão do autor da obra - cativado, fora o protagonista. Considerando a narrativa construída para dar sensação de experiências do jovem viajante, mediando o texto do autor do romance, quero trazê-lo como possibilidade de abrir discussão. Quero com ele, chamar ao estranhamento e suspensão das maneiras quase naturalizadas com que são concebidas as formas de posse, descrição e construção social de sentidos de espaços. As delimitações dos espaços, suas formas, tamanhos e silhuetas ou contornos, carregam tempo.

Se refiz nessa tentativa de preâmbulo informal, alguns trajetos do príncipe, foi para enfocar nos usos e atribuições dadas a algumas espacialidades, às variedades de pessoas e, portanto, de vidas neles inscritos ou ao menos, descritos.

\footnotetext{
${ }^{2}$ Tal qual àqueles olhares direcionados buscando a sua própria cultura, encontrando-a (ou desprezando-a) nos Outros. Da dificuldade de distanciamento, separação ou suspeição do contexto originário de algum(a) autor(a) em relação ao que ele(a) vê é, por exemplo, uma crítica que Durval M. de Albuquerque Junior (2011, p.99) faz a Fernand Braudel, mas que para o mesmo autor não se aplica ao Michel Foucault. "Braudel viaja, mas não sai de casa, não sai do lugar. Braudel encontra o Mediterrâneo e o mundo que este havia criado onde quer que vá." Ainda para Durval M. de Albuquerque Junior (2011, p.97): "Braudel parece estar longe de ter aprendido, com a etnografia, a estranhar sua própria cultura, a se tornar um estrangeiro em sua própria terra, como foi sempre a tentativa da vida e da obra de Foucault." Em alguns diálogos dos percursos ou das formas das trajetórias do Pequeno Príncipe, alguns "olhares" desse viajante me pareceu mais próximo daquele Braudel criticado por Durval do que pelo elogiado Foucault.
} 
A intenção dessa proposta de preâmbulo de tese está, em convidar de maneira menos usual e mais imaginativa, a refletir nas possibilidades diferentes de usos de terras (no caso do príncipe, planetas). Entendendo como sendo diversas, tanto as formas de apropriar de materialidades, como as interações, com o que denominados genericamente de: espaço(s). Quero com essa tese, tematizar algumas camadas de interpretações dadas, em épocas diferentes, a uma determinada parte do território brasileiro. Não quero tratar exclusivamente de períodos, mas enfatizar problemas; relacionar ambos, sem recusá-los. No recorte da abordagem, a pesquisa se insere nas discussões da Geografia História e/ou Geoistória.

A temática. Tendo sido criado durante o Estado Novo (1937-45) cinco territórios federais nas fronteiras Oeste brasileira, pretendi aqui focar um desses cinco territórios. Esse é o ponto de "chegada" no último capítulo. Considero curioso de saída, por exemplo, o nome de uma dessas cinco unidades federais criadas, ter sido denominada "Território do Rio Branco" (que por sinal não é o que estudo aqui). Homenagem e evidência direta ao conhecido diplomata brasileiro, Barão do Rio Branco. É a esse Barão que se atribui papel de conseguir o reconhecimento internacional dos limites e delimitação da fronteira do Brasil com Argentina, tema tratado no segundo capitulo dessa tese, na qual discuto a repercussão da arbitragem dos Estados Unidos em 1895, sobre o litígio. É quase dessa mesma área de Palmas (ou região de Misiones para os argentinos que a reivindicaram) que se cria o Território Federal do Iguaçu cuja existência de 1943 até 1946 é o tema do quarto (ou último) capítulo dessa pesquisa.

Entre a arbitragem dos limites na Questão de Palmas em 1895 e a criação/extinção do Território Federal do Iguaçu (1943) ocorreu no ano de 1929, a considerada primeira presença física de um governante catarinense naquelas paragens chamadas de Oeste catarinense, temática tratada no $3^{\circ}$ capítulo dessa tese. Aqui, há um enlace e relação que me vez acreditar na possibilidade de mobilizar o principezinho de Exupéry, para convidar ao(s) leitor(es) a interpretarmos, como também alguns relatos da Viagem aqui mencionada (estou me referindo agora, a chamada Viagem de 1929, do governador de Santa Catarina, Adolpho Konder) fizeram representações dos espaços, assim como entendo ter feito, através de algumas personagens, o autor d'O Pequeno Príncipe. Trata-se de discutir também formas (às vezes sutis) de apropriação espacial.

Uma concepção minimamente informada não trata de geógrafos como descritores, "escrevedores" ou relatores dos topônimos dos lugares em oposição aos exploradores. Essa concepção dos fazeres de geógrafos já é, de muito tempo criticada e 
vista como ultrapassada. E, pode-se entender dentro do próprio diálogo entre principezinho e geógrafo, como Antoine de Saint-Exupéry parece querer mostrar um tipo de crítica a essa noção de Geografia apartada da "realidade mais imediata" em que está inserido os sujeitos, atores e agentes que fazem o campo geográfico existir. Entendo existir no diálogo entre o principezinho e o geógrafo, algumas possibilidades de reflexão epistemológica da Geografia como um campo de saber (MORAES, 2000).

Como mencionei, se convido você para continuar a leitura desse trabalho é para a partir de um tipo de literatura, abrir outra perspectiva, não para nos encerrarmos nela. Afinal, a presente tese não está inserida dentro das especialidades de análises literárias, pensei, portanto, em um uso livre, poético e convidativo das passagens do príncipe por alguns planetas, particularmente pela presença no romance de Exupéry, daquele velho geógrafo com sua velha Geografia. A esse senhor do alto da sua escrivaninha, a quem o autor encarregou de recomendar o passeante a conhecer a Terra, pela reputação da mesma, diz o geógrafo ao príncipe.

A própria ideia da expressão territorialização existe no nosso contexto planetário terráqueocêntrico ${ }^{3}$; um tipo de consciência de existências de outros planetas e de outras formas de vidas pode ser uma interessante contribuição ética, mesmo que parcial da obra de Saint-Exupéry. É parcial porque os sujeitos dos outros planetas são todos tratados tão igualmente aos tipos sociais e identitários dos terráqueos, por isso, mencionei no inicio, por exemplo, que todos seis primeiros planetas narrados e seus personagens descritos como do gênero masculino. Diferente da rosa, àquela planta que ficou na casa (na verdade, o planeta) do príncipe, enquanto ele pegava um rumo da mobilidade. Parece haver no enredo de fundo, a privação do espaço público ao feminino, e a livre circulação e acessos aos espaços ao masculino (que são quem dominam todos os seis planetas percorridos).

Obra publicada pela primeira vez no andar da Segunda Grande Guerra, em 1943, poderia refletir as normatividades das relações sociais da época, mas independente disso, os tipos dos moradores descritos no livro generificam os planetas, seria exemplos de relações de espaços generificados. Mas, acredito que também haja partes de maior

\footnotetext{
${ }^{3}$ A tentativa de ironia é limitada, principalmente pelo heliocentrismo, mas quer se propor tentativa de diálogo com algumas discussões do antropocentrismo como faz Bruno Latour (1994) em Jamais fomos modernos: ensaios de antropologia simétrica. "Os relativistas foram convincentes quanto à igualdade das culturas, uma vez que consideram apenas estas últimas. E a natureza? De acordo com eles, ela é a mesma para todos, uma vez que ciência universal a define. Para escapar a esta contradição, eles precisam então limitar todos os povos a uma simples representação do mundo fechando-os para sempre na previsão de suas sociedades [...].” (LATOUR, 1994, p.104).
} 
contribuição ética e crítica das formas de vida nos planetas; terminarei a seguir esse preâmbulo sugerindo algumas delas. Mas quero voltar à temática da tese para amarrar, partindo do pressuposto conceitual, de que as diferentes territorializações não se constituem de uma maneira única, universal e exclusivamente homogênea, mas quase toda territorialização é atravessada por poder(es) que às vezes, chegam a conviver, mesmo em disputa pelo (pré)domínio. Ou de como os espaços também são utilizados, mobilizados e usados pelas pessoas para angariar status e variados capitais; parte disso que se trata nessa tese.

Quero aqui lembrar, para relacionar, àquelas quatro grandes variadas maneiras de conceber e interpretar as formas de gestão e modos clássicos de apropriação (VIEIRA, BERKES, SEIXAS, 2005), quais sejam: a) Propriedade Estatal; b) Propriedade Coletiva (ou livre acesso); c) Propriedade Privada; d) Mista. A partir dos 6 planetas que percorre o príncipe viajante, acredito ser possível fazer associação a algumas maneiras de apropriação e gestão do que podemos denominar de: recursos, solo, terra ou, patrimônios naturais (no caso da obra literária, falava-se de planeta). $\mathrm{O}$ mais radical exemplo de apropriação privada é a do empresário que a tudo deseja possuir, pois, ao valorar o mesmo, buscava conquistar progressivamente maiores domínios. Quero fazer daquele relato, um exemplo de perspectiva de desapossamento coletivo (HARVEY, 2005). Para alguém empreender a posse das estrelas, desejando privar todos os demais do poder sobre as mesmas (mas, ao mesmo tempo, esperar que todos tenham interesse por possuí-las); e por conseguinte, da riqueza como sinônimo da exclusividade e valor na individualidade. Noção que o príncipe via sem sentido para as pessoas e, mais ainda, para as próprias estrelas (elas são “donas” de si mesmas).

O planeta do rei, talvez o melhor paralelo esteja na intenção do governo das pessoas e dos corpos e em segundo plano, governo dos espaços. Talvez, por isso, a ele rei, convinha ali habitar o principezinho: governar espaços sem vida social é como governar espaços desprovidos de sociedade; natureza. Já no mundo do bêbado é quase um livre acesso, o planeta não teria regramento de apropriação. Ou ainda, poderia ser um exemplo, de regra mista de apropriação do planeta, ou abandono por não uso.

Considero oportunamente possível, sim, convidar para leitura das páginas que seguem essa tese, com um "preâmbulo" que relatou de alguma forma, o príncipe que partiu do seu planeta e encontra tipos humanos, até que o geógrafo o recomende ir até a Terra. 
Fiz uso - ou para alguém, um abuso inapropriado? - do texto de Antoine de Saint Exupéry, piloto postal que chegou a pousar várias vezes na Ilha de Santa Catarina, quando em direção a Argentina. Utilizava de uma praia para (aterrizar e decolar e) fazer paragens, inclusive, sendo atribuído a ele, a influência na toponímia do local em que fazia seus pousos (campo de pesca em francês virou): Campeche. Ao longo dos próximos capítulos da tese, quem a ler, talvez lembre em fazer comparações, por situações paralelas ou não, com reflexões de Exupéry. Particularmente, considerei válido, do ponto de vista geográfico, mobilizar nessas páginas iniciais, trechos d' $O$ Pequeno Príncipe, pela possibilidade de querer ali exemplificar apropriação, discursos e usos de espaços e também olhares dissonantes, dúbios e ambíguos do ser geógrafo. Sábio de coisas inscritas dentro de imensos almanaques, cujo utilidade decepciona ao viajante.

Apresentei como eu entendi e interpretei parte dos diálogos do príncipe quando passando pelos planetas, fiz com intenção de homenagear a obra e autor, mas não apenas como inspiração, lembrar que o mesmo texto clássico também possui seus limites, posto que é vivo, ainda lido, circula, é popular, pode e merece ser discutido por vários ângulos. Mas quero declarar enfatizando a possibilidade do uso político de algumas discussões ali descritas, espero tê-lo feita e convido para continuarmos nas paginas seguintes outras discussões de usos - por isso, território - espaciais, agora sim, na Terra, particularmente em partes do que chamamos Brasil. 


\section{INTRODUÇÃO}

Integrar para criar, com essas palavras intitulava a primeira versão do préprojeto de investigação da presente pesquisa, quando a apresentei em maio do ano de 2011. Fazia parte da candidatura para ingresso na pós-graduação em Geografia Humana a entrevista com orientador pretendido. O diálogo com Professor Dr. Antonio Carlos R Moraes se deu desde 17 de maio de 2011; orientação iniciou com base naquele projeto.

O tema, Santa Catarina. Mais especificamente, o histórico da constituição de uma comunidade de interesse(s), com papel relevante na construção de integração e coesão do espaço catarinense. Hipótese: como construção social, o território catarinense também havia sido colocado dentro de um dispositivo de constituição imaginada da sociedade. Como quer Benedict Anderson (2005), símbolos, rituais, crenças, linguagens, veículos de comunicação, monumentos, História, Geografia, mapas, entre outros, a enfatizar, instituir e fazer criar as semelhanças. Consolidar sentimento de pertença, palidecer diferenças; esquecer no cotidiano as oposições, as distâncias e os estranhamentos (estrangeirismos) entre "membros" de uma mesma comunidade. Qual teria(m) sido a(s) maneira(s) de Santa Catarina requerer ${ }^{4}$ como uma unidade particularizada do Brasil, ao mesmo tempo, guardar uma heterogeneidade sócio-espacial tão complexa? Essa era uma das questões de fundo.

Durante bom tempo da entrevista e primeira conversa com professor Antonio Carlos R. Moraes, ficamos tratando das possibilidades da discussão em torno de um governador do Estado de Santa Catarina ter - fato que não completou um século - se utilizado de uma Viagem por áreas catarinenses, como dizendo ser uma Bandeira. De um movimento com presença do governante ao extremo Oeste e fronteira, fazia-se um bandeirante. A mítica "bandeira paulista" em pleno ano de 1929, vinha a falar do território, mas também, de processos de apropriação de áreas, invenção de sentidos, criação de regiões e acima de tudo, constituição de comunidade de pertencimento. Não seria o governante um desses "símbolos de força" na tentativa de cimentar, agregar e juntar o que parecia estar disperso, separado? Corporificando o espaço do Estado na representação dos símbolos, serviços e agências como, hino, bandeira, escola, correio, cartório, polícia e o próprio corpo do governante, sendo levado a ser visto nas paragens

\footnotetext{
${ }^{4}$ Excelente estudo inspirador foi criativa pesquisa Álvaro L. Heidrich (2000) tratando do regionalismo no Rio Grande do Sul, livro publicado pela editora da UFRGS intitulado, Além do Latifúndio: geografia do interesse econômico gaúcho. Originalmente uma tese de doutorado em Geografia Humana (USP).
} 
mais distantes, da alteridade daqueles sertões, Outros geográficos. Análise dessa discussão é realizada no capitulo $3^{\circ}$ da presente tese.

A política, os interesses, a economia, o Estado, enfim, os usos sociais dos espaços geográficos ao longo do tempo, conduziram uma difícil, lenta e mesmo nunca completa (e artificial, porque criada) "homogeneidade" territorial de Santa Catarina. Uma análise de longa duração temporal ajuda a compreender os processos da emergência de uma particular parte do mundo, construída como espaço catarinense (aqui não se pretende atingir completude de 3 ou séculos sobre essa territorialização).

Mas, afinal, quando começa um espaço, Santa Catarina? Eis, uma daquelas perguntas inesperadas de entrevistador, que desmonta o entrevistado; e eu ali com uma questão lançada a mim sem saber respondê-la. Vindo de Santa Catarina, interrogado por um Professor mineiro radicado em São Paulo, afirmei na entrevista: - Não sei... titubiei, balancei, dei graças a Portugal e apelei: - Foi Capitania de Santana.

Ufa! De todo, uma entrevista de ingresso ao doutorado (como quem quer um emprego) não se tinha jogado fora por uma "simples rotineira" pergunta. Entretanto, não diz muito coisa, ou se for é pouco, pois não era simples assim, recorrer as Capitanias Hereditárias como explicação segura, tranqüila e confortável, como àqueles que buscam uma gênese sempre acabam encontrando-a. Antes disso, já nos ensina a escola básica, o Tratado de Tordesilhas terminava no sul da América portuguesa em Laguna (SC), orgulhem-se brasileiros-catarinenses! Realmente, não se tratava desse tipo de discussão a buscar a origem pela origem. Compreender formação territorial, certamente envolve um grau de criticidade e complexidade, muito mais dos que fazem cronologias.

Marco fundamental da base de formação territorial de Santa Catarina está na criação da capitania subalterna em 1738 , como discuto no Capítulo $1^{\circ}$ dessa tese, com uso de literatura que já tratou dessa temática. Sendo, apenas, inicialmente, sua abrangência a Ilha do mesmo nome. Com a expansão incorporando outros domínios e enclaves "marítimos portugueses", passando a serem juntados a ela, São Francisco e Laguna... Santa Catarina adentra as duas primeiras décadas do século XIX como uma estreita faixa de terra litorânea e nada mais. ${ }^{5}$ Armações baleeiras implantadas nas baias mais propicias, com uso de mão de obra escrava, produção de farinha de mandioca, o

\footnotetext{
5 “Até o início do século XIX, a Capitania de Santa Catarina restringia-se, na prática, apenas ao governo da ilha que lhe inspirava o nome e às pequenas vilas litorâneas de São José, São Miguel, Laguna e São Francisco do Sul." (MACHADO, 2004, p.124)
} 
destaque no período colonial não é tanto econômico, mas muito mais militar e claramente estratégico.

A partir do ingresso no doutoramento em Geografia Humana e amplitude da leitura do período colonial, vim a compreender esse momento como de fundamental importância para as bases e emergência do território de Santa Catarina. Estou convencido de quem não recuar, fugir ou evitar esse período - séculos XVIII e XIX simplesmente, não bem articulará dimensão tempo, na dinâmica espacial catarinense e sua relação direta com demais espaços Ibero Americanos.

Propus fazer no primeiro capítulo, um panorama mais abrangente, tratando da discussão de quando se delimitou uma toponímia Santa Catarina. Ao colocar relevância da discussão desse período na criação do espaço Santa Catarina, optei por tratá-lo junto da sua capital. A localização da sede administrativa na Ilha - que vai nomeando ao incorporar cada vez mais largas faixas de espaços - foi decidida no período colonial; poderia ser ela, a capital, uma rugosidade no território? Quero defender esse ponto de vista de interpretação, além de sugerir a possibilidade de ampliar a própria noção do conceito de rugosidade para além de formas fixas, as decisões e atitudes políticas. Essa ideia da capital marítima militar, como uma rugosidade da sede de governo é apresentada no primeiro capítulo, no debate sobre armação territorial.

Ressalva: talvez, a melhor data e período nem esteja no século XVIII - não seja estritamente, 1738 - mas antes, 1680, a fundação da fortificação para assegurar aos portugueses a margem esquerda do Rio da Prata, a Colônia do Sacramento, a quem progressivamente a Ilha vai ser ponto de apoio. Meio que "posto avançado" do Rio de Janeiro, meio que "ponto de apoio" ao Sacramento na empreitada portuguesa, em querer dominar desde o Amazonas até o Rio da Prata. Nessa imensa América portuguesa, cuja unidade natural só aparece aos olhos portugueses, e claro, na sua cartografia bastante intencional; nos mares do sul, à Ilha passou a ter um certo destaque de centralidade.

No arco de proteção às vulnerabilidades meridionais da América portuguesa, parece haver certo apoio e concatenação, como por exemplo, assim interpretou já no finalzinho do século XIX, Paranhos Júnior, - o Juca - Barão do Rio Branco, num dos seus processos mais célebres, o primeiro em que atuou na defesa do Brasil em litígio fronteiriço; nesse caso, com a Argentina. Conhecedor de história, apaixonado por mapas e profundo observador das dimensões do Rio da Prata, o Barão escreveu ${ }^{6}$ como uma

\footnotetext{
6 “[...] o general Silva Paes”, segundo disse Barão do Rio Branco (2012, p.86) quando por volta de 1749, retorna esse general português para Europa: "chegava do Brasil, onde estivera quatorze anos no Rio de
} 
espécie de "macro" Brasil meridional, muitas vezes defendido e "em guarida" por mesmos projetos e indivíduos, como é o caso, por exemplo, de José da Silva Paes. Que segundo o Barão, Paes passa por Colônia do Sacramento, barra do Rio Grande e na Ilha de Santa Catarina; sendo um projetista e militar, articulador da fortificação portuguesa e de buscar domínios do Prata. A Ilha está na dinâmica de disputa da conquista do Prata.

Certamente, se não “o início”, mas há uma ruptura na influência da constituição da territorialidade de Santa Catarina, com a fundação em 1680 da Colônia do Sacramento.

Mas Santa Catarina não ficou apenas à beira mar. E por conta dessa circunstância espacial de até 1820 ter sido apenas e exclusivamente marítima, ou ao menos, litorânea, abre-se à condição que marcará a complexidade de uma dinâmica territorial dúbia - que talvez influa até os tempos presentes? - e de lenta agregação. Quando se anexa a ela a área do planalto - até então - paulista, passa-se a exercer em uma mesma administração Estatal do espaço, duas dinâmicas de formação social diferentes.

Em 1820, por decisão do rei, o município de Lages foi desmembrado da província de São Paulo e anexado à de Santa Catarina, ao que consta para ter assistência mais próxima da capital litorânea, em razão da crise sofrida por Lages devido aos constantes conflitos com indígenas na região. Mas a proximidade com a capital litorânea era apenas geográfica. $\underline{O \text { único caminho }}$ que então ligava Lages ao litoral, a estrada Lages-Laguna, era apenas uma pequena picada que descia da serra [...]. (MACHADO, 2004, p.124) (destaques feitos por mim)

A circunscrição em uma mesma esfera - Santa Catarina - com a entrada (dos caminhos das tropas) do Planalto, na até então circularidade marítima, constitui um alargamento de espaço. Mas, no processo de ampliar a "delimitação" catarinense, havia as cadeias das Serras Geral e do Mar como limite entre litoral e as áreas de cima da serra. A desanexação de Lages, colocando-a como à Santa Catarina dará um tom dúbio, no sentido de não naturalmente integrador, aos processos de busca da construção territorial catarinense, pós 1820.

Janeiro, em Santa Catarina no Rio Grande do Sul e em Colônia do Sacramento.” Nessa outra passagem reforça a ideia de uma gestão com certa coesão de um território da América portuguesa meridional, segundo do Barão do Rio Branco (2012, p.74): "De 1735 a 1737, a praça da Colônia, então comandada pelo general Vasconcelos, foi de novo atacada e assediada pelos espanhóis. Uma expedição dali saída, sob o comando do general Silva Pais, ocupou (19 de fevereiro de 1737) e fortificou a barra do Rio Grande do Sul, e estabeleceu os postos militares do Taim, Chuí e São Miguel. Nesse território do Rio Grande do Sul já havia, ao norte do Jacuí, vários estabelecimentos portugueses, fundados por brasileiros de Laguna, de Curitiba e de São Paulo.” (RIO BRANCO, 2012, p.74). 
É com esse problema de diferentes circuitos econômicos, diferentes formas de apropriação e uso do solo e marcantes diferenças de estabelecimento de propriedades e relações de trabalho que marca uma dificuldade de fundação de algo em comum. Certamente, partilhar um mesmo espaço é que não foi. Como fundar o comum, no que parece desagregado? Uma Santa Catarina do litoral e uma Santa Catarina do Planalto, ambas um território em construção. Uma terceira Santa Catarina estaria no Oeste, há um dia ser alcançada da condição de sertão. $\mathrm{Na}$ presente tese, se entende como tal conjunção é que, quase sempre, tornará em suspeita a existência do território catarinense, talvez, por isso, e se apelará com regularidade à necessidade de colocá-lo em processo de construção: integrando, abrindo meios de circulação mais ágeis, tentado alcançar comunidade de partilhas, em meio a interesses nem sempre tão comuns assim.

Aprofundando em três momentos, para dar ênfase nesses rituais de fundação: no capitulo $2^{\circ}$ a repercussão e uso do resultado da fronteira Brasil e Argentina com o voto do presidente - Cleveland - dos Estados Unidos (em 1895). Em seguida, o capitulo $3^{\circ}$ a já comentada Viagem do governador ao Oeste de Santa Catarina em 1929 e por último, $4^{\text {o }}$ capitulo trata da criação e extinção de um território federal que incorporou as terras à Oeste do Rio do Peixe, entre 1943-1946 (voltando à jurisdição de Santa Catarina como afirmava o acordo de 1916 - com a Constituinte de 1946).

O que se defende em "lampejos" de fatos extremamente relacionados ao espaço social - e em flashes temporais - é tanto a concepção territorializada do Brasil, como os embates, lutas e tentativas de fazer instituir uma Santa Catarina integrada, mas não enquanto organização societária e sim enquanto um território. Ao buscá-lo incorporá-lo, facilitar passagens, união, enfim, aproximar o que parecia tão distante é o que se pensava como criação de Santa Catarina. Por isso a idéia de integrar para criar: a meta estava em tentar homogeneizar, vincular à capital como influência e ativa, tornar o espaço trafegável, coesa para fazer existir um espaço catarinense comum. Era no espaço que articulado, se daria a articulação da sociedade que estaria "em cima" desse espaço, como se, por exemplo, fosse apenas o formato de um tabuleiro de xadrez a condicionar os movimentos das peças.

A ideia de fazer integrar o território catarinense foi colocada em prática mesmo antes do século XX. No novecentos, por exemplo, vários núcleos coloniais com imigrantes estrangeiros são criados nos caminhos que fazem essa ligação entre áreas litorâneas e planalto, para ajudar no processo de integração. É possível explicar 
parcialmente, grande parte dos incentivos à colonização em Santa Catarina, tratada como mecanismo de integrar regiões (Planalto e Litoral).

Em parte, é como resultado do diagnóstico da desintegração que se passa a valorizar e criar núcleos coloniais. Estou, portanto, de acordo com a interpretação de Paulo Pinheiro Machado (2011), como já também manifestei em outro trabalho, da defesa dessa análise. ${ }^{7}$ Quando Machado $(2004 ; 2011)$ entende a criação estratégica de várias colônias teve, entre outros fins, a intenção de auxiliar em apoios logísticos na realização de deslocamentos. Para esse autor, a colonização em Santa Catarina, através da venda de terras aos imigrantes europeus, foi dirigida com a finalidade de promoção da integração viária da Província: "O governo dirigiu a colonização para a subida da serra, entre outras razões, para a expulsão de indígenas, a manutenção de estradas e a consequiente conservação de caminhos de comércio entre o planalto e o litoral." (MACHADO, 2011, p.06).

Imagem 1: Áreas com presença de colônias planejadas em caminhos da integração

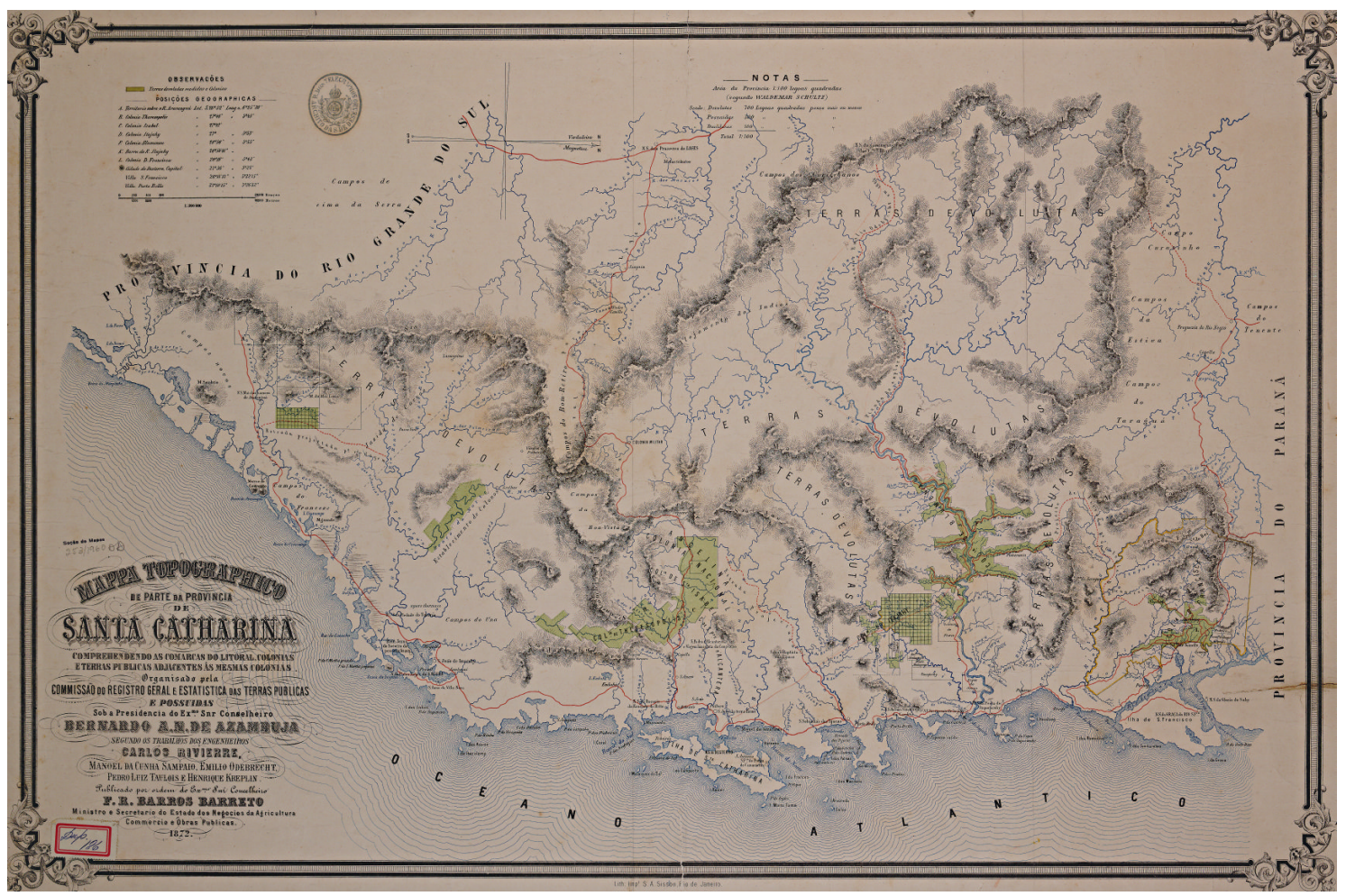

Imagem disponível gentilmente, da pesquisa e arquivo particular levantado pelo Prof. Dr. Alcides Goularti Filho (UNESC), de Criciúma, a quem agradeço. Chamo atenção para além da topografia da imagem, às linhas avermelhadas representando caminhos, e os respectivos projetados coloniais que muitas vezes forneciam mão-de-obra para construções dessas estradas e também manutenção das mesmas.

\footnotetext{
${ }^{7}$ Dissertação de Mestrado (em História) na UFSC, (MARTINELLO, 2012) intitulado: Insulares Santas Catarina: construção territorial, vínculos de pertencimentos e discursos da desintegração (1950-1970).
} 
A imagem anterior ( $\left.n^{\circ} 01\right)$ localiza muito claramente as colônias instaladas no século XIX nessas "manchas" representadas como esverdeadas nas bordas de estradas, como a linha vermelha que apresenta o caminho entre o planalto (Lages) com o litoral. Do norte ao sul de Santa Catarina, há colônias implantadas para auxiliarem nas conexões.

A colonização é também resultado dos interesses de fazer existir e manter estradas em Santa Catarina, tornando tais espaços trafegáveis e confiantes a passagem, ampliando, portanto, a comunicação. A ideia da necessidade de aberturas de caminhos passa a vigorar como um dos principais projetos do Estado. Passando-se a planejar e ser completada por eixos viários, a comunicação do território, por isso, demandar a colonização que, por sua vez, resultaria em integração. No Brasil Independente, a primeira colônia em Santa Catarina criada, em 1829, justamente nas "bocas do sertão" (PIAZZA, 2000, p.30); chamada de São Pedro de Alcântara, localizada para apoiar a existência e manutenção do caminho para o Planalto. Sendo a primeira das comunidades rurais germânicas estabelecidas, buscava-se o progressivo contato entre espaços, como também assim interpretou ${ }^{8}$ Giralda Seyferth (2009, p.275).

Alguns projetos de colonização em Santa Catarina foram colocados em prática, baseando-se seus discursos, entre outros, na ideia de possibilitar maior facilitação da circulação por estradas. Passa haver um entrelaçamento e mesmo enredo, quando se tratava de termos como: estradas, colonização, agricultura, abastecimento, apropriação e conquista (estabelecimentos de propriedades privadas) do espaço. Parte influente da política territorial do Estado de Santa Catarina no século XIX ocorre na prática, via projetos de colonização em pequenas propriedades rurais. São partes de uma mesma engrenagem e não devem ser encarados setorialmente ou "independente" de uma mesma política: população e território. Quando no segundo capítulo da tese apresento o caso de um geógrafo-agrimensor "escalado" para mediar áreas do litígio com a Argentina, no Oeste, nas correspondências dele - Emil Odebrecht - é perceptível uma forte vinculação à região em que se insere como imigrante (Vale do Itajaí), em um processo colonizador.

\footnotetext{
${ }^{8}$ Para Giralda Seyferth (2009, p.275): “A fundação de São Pedro de Alcântara, em 1829, marcou o início da colonização estrangeira em Santa Catarina. Naquele núcleo, situado no caminho do sertão que conduzia cargueiros à Vila de Lages, no planalto, 146 famílias alemãs e 112 soldados da mesma origem, [...] receberam lotes de terras para cultivo."
} 
Algumas das tão famosas colônias de imigrantes europeus, criadas em pontos específicos do sul do Brasil no século XIX, foram pensadas como estratégicas para contato entre dualidades que informam muito desse enredo territorial: litoral e interior (Sertão) e, também, como garantidor de domínio do espaço nas históricas disputas na macrorregião da bacia do rio da Prata. Pode recorrer-se ao fator locacional como chave para a compreensão da instalação de colônias em determinados pontos de Santa Catarina: "[...] a colonização com imigrantes surgia como solução para povoar [com brancos] o território, especialmente em algumas bacias hidrográficas que pudessem assegurar a comunicação por terra com o planalto atravessando a Serra do Mar." (SEYFERTH, 2009, p.275). Acredito que muito das identidades, vínculos de pertencimento e concepção do passado de comunidades e de indivíduos catarinenses se ancore, nesses projetos de colonização em pequenas propriedades agrícolas familiares.

Se de um ponto te vista territorial, é possível afirmar a existência de constituição de regionalismo, acredito que uma das mais difundidas maneira de - se é que se pode falar dessa forma - se pensar catarinense, muitas vezes é associada a um padrão de ocupação e peculiar ao Brasil. Embora uma interpretação ensaística, acredito que em algumas das áreas de Santa Catarina de forte presença e vinda de imigrantes no século XIX e XX, com população de origem européia ou descendente - em lotes de faixas de terras - influenciou na identidade de pertencimento comunitária, regionalismos, com imaginário, vínculos e até sentimento de pertença às vezes "extraterritorializados"9 ligada à comunidade local e a narrativa do processo de colonização. Com "brasilidade" ou identificação de símbolos identitários ambíguos, pode-se argumentar como hipótese de saída de investigação, a constituição de regionalismos, em que, um peso muito importante é atribuído à vinda, chegada, instalação em lotes coloniais e processo de territorialização de imigrantes europeus. Como se houvesse um hiato nessa identidade,

\footnotetext{
${ }^{9}$ Um exemplo muito marcante da permanência de vinculação com uma Alemanha em processo de construção nacional será visto no subtópico do cap.2 sobre Emil Odebrecht. Aqui quero apontar também o caso de uma revista de Blumenau divulgando aos seus leitores que lessem a biografia do, como diz o periódico, mais sábio dos naturalistas, Alexander von Humboldt. “- Dr. Karl Fouquet - Instituto Hans Staden - São Paulo - 1959 - O Dr. Fouquet, autor do trabalho que nos foi oferecido, com honrosa dedicatória, é um nome conhecido nos meios intelectuais do Brasil e da Europa, pelas suas valiosas contribuições ao estudo de personalidades que prestaram serviços [...] ao engrandecimento cultural e material do Brasil. [...] Karl Fouquet tem-nos dado obras interessantes à história de Santa Catarina, como a biografia do Dr. Blumenau e o relato minucioso de sua atuação no estabelecimento que fundou as margens do Itajaí. O livro que temos sobre a mesa, é uma esplendida contribuição às comemorações do centenário da morte de Alexandre Von Humboldt, cuja vida e obra o dr. Fouquet focaliza com absoluta segurança e elegância de linguagem. É um trabalho que não pode faltar na biblioteca de todo homem de inteligência, dada a universalidade da fama de Humboldt como um dos maiores sábios naturalistas de todos os tempos." Blumenau em Cadernos, Tomo III, janeiro de 1960, n.01, p.37.(destaques meus)
} 
pois se relacionam fortemente com o regional e com o imaginário da nação em que são "originários" seus sobrenomes, dando um pulo (às vezes esvaziando) identificações com nação, Brasil.

Um regionalismo com carga de descendentes de estrangeiros e “eurodescendentes", como contribuintes com o País, ao seu próprio modo, pois o Brasil os recebeu, mas, não se percebem brasileiros. Apenas, por serem parte do processo de instalar-se e constituírem apropriação do espaço (realização de posse da propriedade privada rural), algumas vezes visto como um sinônimo de estarem melhorando o Brasil e ajudando na construção da nação. Entretanto, tais discursos positivados de melhoramento do Brasil pelos imigrantes e seus descendentes, se daria no trabalho realizado - como se discutiu, como dito, no cap. $2^{\mathrm{a}}$ a respeito de Emil Odebrecht - na própria comunidade menor, desde seus lotes coloniais até apoio àqueles que ficaram na Europa: enviando a eles recursos, apoios e mesmo a impressão de estarem fazendo (continuando, expandindo) no Brasil um progresso semelhante, ao que seus familiares antepassados haviam feito na Europa, com a diferença daqui ser uma missão árdua: domar a natureza francamente hostil.

Houve interesse e preocupação em facilitar comunicações com apoios mínimos e essenciais dos caminhos, por isso, da concessão de terras próximas a eles e a colonização nessas estradas. A colonização desempenou um papel central na constituição de circuitos de trocas e lucros em Santa Catarina e, mais ainda de comunidades de interesses (MORAES, 1991).

Por que se deve conceder terras próximas de caminhos de passagem? Porque assim os 'caminhantes' podem achar casas para se abrigar e canoas para o transporte, quando necessário. Esse fato é extremamente importante, porque a própria possibilidade de se utilizar um caminho, está na existência de um pouso no seu percurso. Se a estrada está abandonada e não é utilizada, é porque ela não serve como rota comercial, e ela não é utilizada pelos comerciantes, porque não há ao longo de suas extensões um lugar em que se possa pernoitar ou que sirva de abrigo. (SALOMON, 2002, p.156).

A abertura de estradas, como um dos impulsos importantes para a criação de colônias, não parece ter sido exclusividade de Santa Catarina. Basta lembrar, como faz Paulo P. Machado (1999), das importantes concessões de terras para a criação de colônias que fizeram parte da proposta de integração de algumas regiões no Rio Grande 
do Sul. ${ }^{10}$ Mas em Santa Catarina, parece esse processo de colonização ter desembocado em regionalismos.

Também não podemos aceitar que a colonização significou "ocupação" no sentido de não existência anterior sociedades nessas áreas que passaram a ser de colonização. Não estou de acordo com a idéia de que os vazios demográficos foram ocupados primeiramente por colonos, pois tais fundos territoriais foram motivadores da cultura imigratória, embora não fossem desocupados. Certamente, houve constantes tentativas de esvaziar a presença indígena em variados espaços. Ainda que muitas áreas fossem tratadas como imensas florestas vazias, o Estado demonstrava também saber da existência de moradores ancestrais em muitos lugares. Como bem disse Luisa Wittann (2007, p.61), “A violência contra os índios estava na base da colonização.” Essa historiadora realizou farta pesquisa que demonstra como o aparato estatal chegou a conhecer e a travar planos em detrimento da reprodução sócio-cultural dos indígenas, inclusive com ações diretas contra tais populações, vindas de governantes.

Luisa Wittmann (2007) compreendeu como a implementação de caminhos foi um dos importantes e fortes mecanismos para submeter aos colonizadores as populações que viviam antes da chegada dos brancos: “A solução da questão indígena viria através da transformação da selva em morada do moderno. A mata receberia estradas que, rasgando o verde, permitiriam a subjugação dos chamados selvagens. A vitoria de uma outra cultura mudaria os índios.” (WITTMANN, 2007, p.61).

É preciso sempre ter em mente que a ideia de colonização pioneira significa também, a diminuição de acesso a bens da população nativa que até então tinha nos recursos daqueles espaços a sua base de reprodução material. Isto por que, no começo do século XX, quando havia referência em documentos oficiais aos (considerados naturais do lugar) autóctones, geralmente era para descrever a necessidade de catequização de indígenas e criação de "aldeamentos" como forma de pacificação. Ao contrário de pensar como vazios não habitados, é demonstrado pelos textos do governo que se tratava, muitas vezes, da presença dos indígenas como o problema. "A violência dos chamados caçadores de bugres marca a história catarinense.” (WITTMANN, 2007, p.61).

\footnotetext{
10 "As colônias provinciais foram fundadas em regiões mais distantes - onde ainda havia terras públicas com o objetivo de dirigir a ocupação territorial no sentido da integração viária da Província." MACHADO (1999, p.24-25).
} 
As expressões usadas demonstram qual o posicionamento que o aparato governamental seguia. Se houvesse muitos indígenas em determinada região ou localidade, poderia ser descrita como "infestada de silvícolas". Quando se tratava das estradas e interesses de circulação, principalmente de colonizadores, as mensagens de governo deixaram claro que tratavam os indígenas como se houvessem invadido áreas e espaços, impedindo caminhos de serem construídos ou percorridos. Os grupos indígenas eram tratados como entraves à circulação, e a opção seguida foi a de realizar proteção aos colonizadores. "Em 1836, é criada na província de Santa Catarina, uma Companhia de Pedestres com o objetivo de, entre outros, 'proteger, auxiliar e defender os moradores de qualquer assalto do gentio, malfeitores e fugitivos' [...]". (SALOMON, 2002, p.250). Os indígenas foram colocados entre os inimigos que ameaçavam dos brancos colonizadores.

As políticas de promoção do governo declaravam proteger a vida de quem desejasse passar pelas estradas, mesmo que fosse necessário, para isso, se precaver atacando "silvícolas" (tratados como não-civilizados), conforme os relatórios do governo no início do século XX expressavam. Os indígenas não eram vistos como pessoas pelas ações Estatais (MACHADO, 2004, p.58). Os projetos de intervenção buscavam, acima de tudo, confinar essa população: “[...] os confinamentos indígenas terão a função de isolar estes grupos com intuito de torná-los dóceis para a vida em sociedade. Durante anos se fará o elogio a esta 'pacificação'." (SALOMON, 2002, p.259).

A longa política de integração do território de Santa Catarina esteve associada e colocada em prática, paralelamente, à preferência pelo embranquecimento da população. E a governamentalidade (FOUCAULT, 1970) favorecia e instrumentalizava o aparato Estatal em favor do imigrante colonizador: "Desde que foram criadas, as companhias de pedestres tinham a função de afastar os indígenas para este interior desconhecido do qual não deveriam sair. [...] empurrá-los para dentro deste espaço e não permitir que a vida errante dele se afastasse." (SALOMON, 2002, p.255). Dos brancos, esperava-se o papel de fazerem a integração do litoral-interior. A colonização européia em Santa Catarina foi mais do que a formação de um campesinato com acesso às pequenas e médias propriedades de terras. O processo de formação territorial é profundamente violento em relação à cultura indígena. Uma das primeiras comunidades rurais germânicas pode bem exemplificar como dela esperava-se, em conseqüência da colonização, a integração, como assim havia sido planejado: 
A localização de São Pedro de Alcântara, por sua vez, revela a intenção de povoamento, partindo de um ponto estratégico, pois veio a concretizar antigo projeto de instalação de um povoado que tornasse seguro o caminho para o planalto, ameaçado por temidas incursões indígenas. (SEYFERTH, 2009, p.276.)

Percebe-se, ao analisar mensagem dos governos catarinenses que, ao defender interesses de circulação e livre acesso dos colonizadores, torna os habitantes autóctones aqueles que deveriam ficar reservados a espaços nos quais não passassem estradas, nem "pessoas". Aos indígenas é atribuído o papel de tornarem inoportuno o deslocamento de valores e de proprietários desses valores.

Ao tratar algumas populações autóctones como intrusas e estranhas, o posicionamento governamental opta por lógicas que queriam naturalizar-se e se impor como dominantes, sendo que uma territorialidade colocou-se àquela existente preteritamente. Numa espécie de "reclamação", conforme consta no relatório do governante, apresentado no ano de 1916, defendia claramente o lado dos colonizadores, quando dizia: "É sabido que em Blumenau e outros pontos os selvícolas inquietam os colonos, destroem as suas propriedades quando não os atacam, massacrando-os." (SCHMIDT, 1916, p.76). Embora, no mesmo documento tenha afirmado que "Torna-se, pois, impossível a localização de colonos nas regiões frequentadas pelos índios." (SCHMIDT, 1916, p.76), sabe-se de não autodeterminação ou respeitado limite da "territorialidade autóctone", mas sobreposição ou imposição da colonização em espaços de vida das culturas indígenas. (MARTINELLO, 2012).

No terceiro capítulo, a Viagem e presença de um primeiro governador de Santa Catarina ao Oeste, fez do imaginário da conquista e nacionalização do Sertão, o mote do mito Bandeirante.

\section{Geografia Histórica: volver}

Estariam membros da comunidade de geógrafos reescrevendo ou, desejando escrever, suas próprias histórias? Não se trata disso, quando pretende conjugada em uma expressão só, discussões de espaço e tempo. Não é uma reivindicação de uma minoria, apontando como se vítimas das mutuamente apartadas ${ }^{11}$ História da Geografia

\footnotetext{
${ }^{11}$ Como Maurício Almeida de Abreu (2010, p.17) afirmou, é desejável cultivar pontos de encontros e algumas concordâncias, para haver mais aproximação; como lembra o autor um dos maiores paradigmas da afinidade entre temáticas dessas disciplinas está nas gerações fundadoras do movimento dos Annales: "Para que essa contribuição seja efetivada [A Geografia Histórica], é importante, entretanto, que algumas barreiras que a separam da história sejam eliminadas. Sabemos que no início do século XX a separação entre essas disciplinas era bem menor. Os historiadores não dispensavam a análise dos 'quadros' naturais
} 
ou Geografia da História. Mas, nem por isso, seria menos legítimo, caso geógrafos desejassem maior movimentação e refinamento, uma "própria" abordagem de sua comunidade (seu campo), com "suas versões" do passado. Não é algo menor, pesquisar como na Geografia ocorreram históricas disputas nas formulações de conceitos, nas validações de temas e objetos ou sujeitos a serem questionados. Tanto possível, quanto uma história da geografia que buscasse compreender, por exemplo, a percepção dos embates nas elaborações de currículos escolares e universitários.

A Geografia tem sua história: mas tal perspectiva não seria o foco da Geografia Histórica; embora também, não deixe de ser parte relevante. De maneira que, ao menos no Brasil, tem sido até comum quem se proponha a fazer estudos em Geografia Histórica, também realizado pesquisas sobre aspectos da história da disciplina. Às vezes, parece confusa a difícil margem de delimitação da História dos Pensamentos Geográficos, com Geografia Histórica. Mas não significa a mesma coisa. Considero o nome de quem mais bem tenha feito associação entre Geografia Histórica e História(s) da Geografia: Antonio Carlos R. Moraes (1991). E não o fez de maneira simplória e descritiva (longe disso), como se paralelos simples. Conseguindo bem associar crítica e criativamente, subcampos, como variáveis chave da Geografia Humana. ${ }^{12}$

As versões sobre o passado estão em disputa e, portanto, das formas de se fazer História. Buscar convencimento e mobilizar "a maioria" para consolidar interpretações, não deixa de ser competição para imposição de sentido(s). Até mesmo, do que venha a significar História, o que por si só configura um aberto e constante litígio. ${ }^{13}$ Já não é mais simples e nem confortável, dialogar com quem se acomoda na visão ingênua e pronta sobre a ideia de existir uma restrita "verdade" (quase sempre é a verdade de quem próprio a anuncia). No mínimo, não se poderia recusar como muito se compete, para tornar hegemônica alguma versão do mundo; e quando aparentemente hegemônica determinada interpretação, logo alguns passam a tratá-la como a mais verdade(ira).

\footnotetext{
e territoriais que balizavam os processos sociais que estudavam, e não foram poucos os que elegeram um recorte espacial para circunscrevê-los - a tradição de estudo da Escola dos Annales prova isso muito bem. Os geógrafos, por sua vez, dedicavam uma boa parte de suas monografias ao estudo do processo histórico da região analisada, buscando nele elementos que os ajudassem a singularizá-la. É verdade que poucos foram os estudos que conseguiram verdadeiramente interar tempo e espaço, ou melhor, período e lugar e região. A monumental obra de Braudel sobre o Mediterrâneo, assim como certas obras clássicas da geografia regional são assim, exceções e não a regra.” (ALMEIDA, 2010, p.17).

12 “[...] ver a geografia humana em si, como uma modalidade de história.” (MORAES, 2005a, p.39) é abordagem presente no marcante livro desse autor: Território e História do Brasil, por exemplo.

${ }^{13}$ Ver mais em: JENKINS, Keith. A história repensada. $4^{\mathrm{a} e d .}$ São Paulo: Contexto, 2013.
} 
Então, disputa-se a verdade, se disputa das formas de se ver(em), negarem ou silenciar tentando, dirigir sentidos - sobre "o que se passa" ou o que se passou.

O método e os recortes temáticos das proposições da Geografia Histórica, não visam em si (ou não se propõe) ser uma interpretação, congregando descontentes com caminhos da disciplina História ou, descontentes com os descaminhos da Geografia. Antes, é uma formulação intelectual tratando de discussões consideradas pertinentes a temporalidade dos espaços, "[...] abrindo-se, portanto, para a ótica de conceber a geografia como uma história territorial." (MORAES, 2005a, p.15). E até mesmo, das condições das espacialidades influírem na História. "Enfim, o desenvolvimento histórico se faz sobre e com o espaço terrestre, e, nesse sentido, toda formação social é também territorial, pois necessariamente se espacializa.” (MORAES, 2005a, p.47)

Geografia Histórica tem como meta, a espacialização envolvida nas rupturas, na continuidade do fluir e existir temporal. Teria suas maneiras (métodos) "peculiares" de atribuir sentidos ao passado; na mesma proporção, em que, observa o espaço presente, em tentativas de retrospectivas temporais. Segundo a opinião de Maurício Almeida de Abreu (2010, p.17), pode-se fazer Geografia Histórica, sem necessariamente chegar até o tempo presente ou explicá-lo na sua plenitude: “A análise de lugares (assim como a das regiões) não precisa, entretanto, estar informada pelo presente; pode-se muito bem concentrar a investigação em tempos pretéritos." (ABREU, 2010, p.17).

Já na visão de Antonio Carlos R. Moraes deve-se, sim, ter o presente como uma das metas mais importante, tanto de ponto de partida para retrospectivas, como para do passado vir a contemporaneidade: “[...] a análise geográfica pode (e deve) utilizar o presente como referência de reconstituição histórica no estudo da formação dos territórios." (MORAES, 2005, p.60).

Entendo como uma das proposições da Geografia Histórica, a meta mais geral e pretensiosa, creditar à associação entre ser e estar; quando e onde; nas mútuas influências do existir no tempo e espaço. Por oposição, talvez pudéssemos inquirir, como duas as principais e maiores negações para uma melhor existência da Geografia Histórica: a) recusa o simples correr da cronologia e dos fatos, como se a História andasse sem gravidade (ou independente do onde); b) o simplório elenco das coisas distribuídas sobre o espaço como se estagnadas, amorfas ${ }^{14}$ ou sem mudanças, como se congelamento eterno.

\footnotetext{
${ }^{14}$ Para Maurício de Almeida Abreu (2010, p.16), além da ampliação da concepção de espaço como em movimento, mudanças e não estanque, houveram também ampliações de várias possibilidades de
} 
Para Maurício de Almeida Abreu (2010, p.22), a Geografia Histórica busca discutir a compreensão dos processos sociais e das formas espaciais, em algum período de tempo e em algum lugar do espaço. Das coisas distribuídas sobre o espaço (conformadoras de espacialidades), sua distribuição, os acontecimentos e a existência (mesmo quando aparentemente, apenas, "fatos"), também influenciados por quem os "sustenta", dá chão, permite eventos se desenrolarem. E por assim permitir, ao permitir, seria também o espaço uma dimensão a considerar influente, mas não isolada, associado ao tempo. Espaço social, um fator; ator e agente a ser levado em conta, na mesma hierarquia do que outras dimensões (nem sempre determinante, nem só submisso). Inclusive, o espaço podendo influenciar em ritmos, (em maiores ou menores) acelerações e particularizar eventos, como os escalonamento temporal proposto por Fernand Braudel (tempo curto/fato; médio/conjuntura; longo/estrutura).

Há muito mais fatores de ordem espacial do que sonha nossa vã historiografia; assim, como há dimensões temporais complexas, não unidirecionais, nem prontas (ou estagnadas) do passado, como parece nem sequer sonhar parte de nossa vã Geografia. ${ }^{15}$ Estou de acordo plenamente, com a seguinte afirmação do geógrafo histórico Maurício de Almeida Abreu: "Sem a recuperação da produção material das sociedades do passado não é possível resgatar as âncoras espaciais que deram suporte à constituição dos lugares e, por conseguinte, a produção de sua história." (ABREU, 2010, p.19)

Seria enfadonho, para não dizer infantil, imaginar que a Geografia Histórica pretendesse impor uma visão de como se faz História. Ou ainda, como dentro da Geografia (para os demais geógrafos) quisesse tomar lição e ensinar-lhes da(s) história(s) do(s) espaço(s). Antes, é uma possibilidade do fazer geográfico. É um discurso acadêmico (treinado, informado e baseado em parâmetros) a respeito do espaço na cadência passado/presente. Não se trata de uma simples cooperação entre disciplinas,

interpretação, não mais sendo aceito uma essencial única sobre um lugar, região, enfim, como se apenas uma matriz conceitual ou teórica conseguisse acessar uma verdadeira e essência de um espaço. "“'O que mudou nas últimas décadas, isto sim, foi a antiga vinculação com a concepção de espaço e, por conseguinte, com a ideia de que regiões e lugares se definiam por sua estrita singularidade na superfície da terra. O estudo das regiões e dos lugares não morreu: o que desapareceu foi a crença de que tanto uma como outras constituem um arranjo espacial final e único, a síntese, por assim dizer, de uma determinada parcela da superfície da terra." (ABREU, 2010, p.19).

${ }^{15}$ Há um campo bastante consolidado, atuante e produtivo de Geografia História no Brasil que não vê as fronteiras entre essas disciplinas como intransponíveis, e sim, como possibilidades de diálogos. Certamente conjunto da obra deixada por Antonio Carlos R. Moraes é uma das referências de destaque nessa produção. Vale apontar a abordagem da Geografia Histórica desse autor que: "Nesse enfoque o território passa a ser visto como um resultado histórico do relacionamento da sociedade com o espaço." (MORAES, 2005a, p.52). 
mas de pensar como espaço não é uma externalidade aos fatos e eventos temporais e socioambientais. Por outro lado, para muitos historiadores, não seria o passado, um lugar? Mesmo que não se permita freqüentá-lo, mesmo se "se vá" apenas por signos, símbolos e restos de discursos - como o escrito - e mesmo que não se consiga sair do presente; a História costuma fazer do tempo, lugares. Mesmo quando - ou somente assim permitido - lugares imaginados.

Não se consegue mudar efetivamente de tempo, não há máquinas para tanto. Mas isso não significa que o espaço também não deixe de ser um veículo de mudança(s), tal como o tempo. Enfim, espaço agente que carrega mudanças. É preciso estar, para ser. Assim como - e para apenas citar uma expressão antiga em desuso, por ultrapassada - uma Antropogeografia não poderia querer impor da Geografia a ensinar aos antropólogos como realizarem suas interpretações, a Geografia Histórica não quer ensinar as dinâmicas da esfera terrestre aos historiadores. Mas pode ter possibilidades de gerar encontros entre ambas; às vezes com problemáticas de certa afinidade e maneiras de pensar questões, para além das fraturas e fragmentações departamentais.

Tenho pra mim, a Geografia Histórica configuraria em uma das características daquilo que o Prof. Antonio Carlos R. Moraes nos disse em uma das suas últimas reuniões de orientação, na sua sala do departamento de Geografia da USP em 2014. Boa discussão ocorrida na presença do Prof. Manoel F. de Sousa Neto e do colega de doutoramento também orientado pelo Tonico, Miguel Vieira de Lima. O Prof. Antonio Carlos R. Moraes como que um apaixonado pelo que fazia, deu um sorriso e nos sugeria como uma de suas indicações a não serem esquecida: das sutilezas da Geografia. Geografia Histórica, uma das sutilezas da produção de saberes e do fazer geográfico. 


\section{CAPÍTULO I}

\section{BASES DA EMERGÊNCIA DO TERRITÓRIO “CATARINENSE”}

\section{Das disposições para sínteses e abrangências}

Estudos de "síntese", apanhados geral e trabalhos panorâmicos, parecem ter pouco prestigio nas humanidades no momento em que redijo essa tese. A presente pesquisa não quer ser um desses, embora também não negue a pretensão da síntese mais ampla.

Vivemos uma época onde John Monteiro (1999, p.259) constatou, no final do século passado, como sendo "Na atual conjuntura de hiper-especialização acadêmica [...]". Max Weber que viveu até 1920 já afirmava: "Em nosso tempo, obra verdadeiramente definitiva e importante é sempre obra de especialista." (WEBER, 2004, p.24), para depois ponderar: "A intelectualização e racionalização crescentes, não equivalem a um conhecimento geral crescente acerca das condições em que vivemos." (WEBER, 2004, p.30).

Parecendo hegemonia do contexto de relativa marcação de discussões por exclusividades, singularidades, caso(s) único(s), particularidades, em um geral de individualidades, esta pesquisa segue na contramão da predominante tendência de contradizer generalidade. ${ }^{16}$ Saudando abordagem denominada por Antonio Carlos R. Moraes (2014, p.12) como:

[...] afã totalizante [que] contrasta-se bem com as proposições metodológicas mais recentes, marcadas por um caráter "aberto", de forte índole não conclusiva e com uma ótica singularista, postura que constitui uma das características essenciais das perspectivas autodenominadas "pós-modernas".

Flertando com àqueles recortes - com resultados, às vezes, positivos - de abordagens gerais, embora não seja esse o tom de todo a pesquisa, essa é a ênfase dada neste primeiro capítulo. Traçarei discussões dos aspectos de "bases" e da "emergência" territorial de Santa Catarina, em uma clara e evidente inspiração em trabalhos precedentes de outros autores, como uma espécie de revisão de literatura específica, ao estilo de estado da arte. Sigo a escrita relacionada, algumas vezes, tanto com aspectos geohistóricos do território brasileiro, como com discussões conceituais.

\footnotetext{
16 "A origem dos principais métodos clássicos em ciências humanas reside em macro-teorizações dotadas de uma vontade totalizadora, que unificam num mesmo discurso um sistema filosófico e uma teoria geral da história e/ou da sociedade." (MORAES, 2014, p.12).
} 


\section{Territorialidade do Estado-nação (mercado em primeiro lugar, na América) versus}

\section{Territórios Sociais, diálogo teórico nas “convivências” tensionadas no Brasil}

É certo que, os espaços são invenções, assim como os conceitos também os são. Mas os sentidos dados a ambos, suas possibilidades de significados alteram-se, modificam-se e sofrem transformações ao longo do tempo. Espaço(s): tão polissêmico(s) quanto as tentativas dos conceitos em defini-lo(s). Há quem enfatize nele(s) - na categoria ${ }^{17}$ mais abstrata espaço(s) - as continuidades, as regularidades e mesmo as ancoragens sociais construídas e "cristalizadas", auxiliadoras da manutenção das permanências. É como tentarei fazer em partes da presente pesquisa, conferindo certa atenção a algumas permanências. De saída, explicito a concordância com a afirmativa "Os espaços são acontecimentos, tanto como conceito, quando como práticas e relações." (ALBUQUERQUE JUNIOR, 2011, p.106).

A modernidade tipifica menos aleatoriamente a terra do que antes; faz do "uso racional" do espaço uma estratégia de ganho (retorno). ${ }^{18}$ Se concordarmos com o texto de uma conferência de 1906 de Max Weber (1986, p.415) quando diz: "Na Europa, o mercado é mais novo do que o produtor."; então, por oposição à tradição do passado (do Antigo Regime) na "velha ordem econômica", este tipo ideal fundado na América institui, com a nova terra uma racionalidade ${ }^{19}$ controladora e lucrativa mais espessa: "O mercado é mais antigo do que ele [o produtor] na América.” (WEBER, 1986, p.415).

\footnotetext{
${ }^{17}$ Por exemplo, um conceito de época pode ser encontrado em Milton Santos (2002, p.150) dos anos da década de 1970 na obra, Por uma geografia nova, quando diz: "O espaço geográfico é a natureza modificada pelo homem através de seu trabalho.” Já Renato Ortiz (1996, p.49) aponta a associação com a materialidade: "Existe nas Ciências Sociais uma forte tradição em se pensar o espaço na sua relação imediata com o meio físico. A evolução da Geografia, a escola de Ratzel, entre outras, é pródiga em exemplos dessa natureza. No entanto, mesmo quando nos afastamos do determinismo geográfico, cuja influência foi grande entre os pensadores brasileiros no final do século XIX, está presente a ideia de território identificado aos limites de sua materialidade." (ORTIZ, 1996, p.49). (destaques meus)
}

18 “[...] no mundo moderno os territórios estão vinculados ao domínio estatal do espaço, qualificando-se como o âmbito espacial do exercício do poder de um Estado." (MORAES, 2014, p.33). Embora não sendo tão claro e entendível quais rupturas acompanham a modernidade, Michel Foucault também teria proposto tal agenda de investigação, segundo afirma Durval M. de Albuquerque Júnior (2011, p.96): “[...] Foucault claramente propõe que se faça uma história da categoria espaço e esboça uma análise da passagem da organização espacial característica da Idade Média, em que prevaleceria o espaço como localização, para a organização espacial do mundo moderno, onde prevalece o espaço como extensão; forma de organização espacial da qual estaríamos saindo para uma espacialidade marcada pela posição.”

${ }^{19}$ O espaço vai se tornando, como disse Milton Santos (1997, p.43) cada vez mais instrumentalizado. A ideia de racionalidade costuma se apregoar como mais capaz e não deixa de ser uma verticalidade. Auto intitulando-se racional, mobiliza discursos buscando hegemonizar e dominar; desqualificando "Outras" práticas de gestões, usos, posses ou apropriações de terras como menos práticas, inferiores, enfim, não 
A América e sua agricultura (leia-se, a exploração/produção) nasceu produzindo para o mercado. Claro, tratando no nível das abstrações dos tipos ideais. Em Alencastro (2000, p.32), um exemplo mais palpável, “[...] o tráfico surge como vetor produtivo da agricultura das ilhas atlânticas.” De maneira semelhante, Eugene Genovese arremata:

O surgimento de um mercado mundial - o desenvolvimento de novos gostos e de manufaturas, que dependiam de fontes não européias de matérias-primas incentivou a racionalização da agricultura colonial sob a dominação feroz de um punhado de europeus. A mão-de-obra africana forneceu a força humana necessária para alimentar o novo sistema de produção em todas as sociedades escravistas do Novo Mundo [...]. (GENOVESE, 1988, p.22).

Embora a apropriação de terras voltadas a produzir para o mercado (lógica racional de mercado precede a produção na América, conforme Weber), tenha influenciado diretamente em uma tipicidade de territorialidade nas Américas; territórios mercantis, controlados por Estados metropolitanos, pode-se dizer; houve outras territorialidades - não apenas para o mercado - convivendo com àquela imposta pelo colonialismo. ${ }^{20}$ Mesmo quando resistindo ou não, sendo subalternas, marginais, sobrepostas, submissas e dentro do desapossamento produtor de mercadoria, a começar pela terra como valor de mercado, mesmo assim, havia e há também territórios sociais (LITTLE, 2004) não submetidos totalmente àquela dinâmica mercantil. Se bem que do ponto de vista nativo - dos autóctones e indígenas - a partir do século XVI "Segue-se um processo de repovoamento colonial e mercantil fundamentalmente baseado no implante de colonos europeus e de escravos africanos." (ALENCASTRO, 2000, p.40). Dito de maneira parecida por Antonio Carlos R. Moraes (2003, p.80): “A expansão territorial - despovoadora na perspectiva dos índios, povoadora na óptica do colonizador - marcou o desenvolvimento histórico do Brasil". Ainda para o mesmo autor: "Os territórios nacionais se formam a partir dos coloniais, e estes foram muitas vezes construídos sobre as formações territoriais indígenas.” (MORAES, 2006, p.11).

Do ponto de vista conceitual, não há consenso em existir apenas um conceito amplo, genérico e acabado de território. Ao contrário, cada vez mais se parece demandar atributos, adjetivos ou explicações de como se está entendendo o sentido do

eficazes. Milton Santos (2004, p.110) perspicazmente captou assim: “As horizontalidades, pois, além das racionalidades típicas das verticalidades que as atravessam, admitem a presença de outras racionalidades (chamadas de irracionalidades pelos que desejariam ver como única a racionalidade hegemônica)."

${ }^{20}$ Aqui, de maneira genérica, pode caber entender com Milton Santos $(2000 ; 2004)$ o colonialismo como verticalidade querendo se impor, em horizontalidades possíveis de resistências por várias sociedades précolombianas. Os próprios "territórios sociais" na expressão de Paul E. Little (2004) são excelentes exemplos de horizontalidades que "não se entregam passivamente" às tentativas de sobreporem-se a elas. 
termo. "O território em si, para mim, não é um conceito" dizia Milton Santos (2000, p.22) na entrevista tornada livro: Território e Sociedade. Território "só se torna um conceito utilizável para a análise social quando o considerarmos a partir de seu uso, a partir do momento em que o pensamos juntamente com aqueles atores que dele se utilizam." (SANTOS, 2000, p.22). Na obra Para uma outra globalização, Milton parece ter buscado cunhar, bem sucedido, uma noção abrangente e possível de território, usado.

Tão fortemente associado apenas a uma compressão jurídica, como área de domínio e influência do poder do Estado, justamente criticado por Paul E. Little (2004), existe uma generalização da ideia de território, de maneira que até mesmos os intelectuais e as reflexões pretensamente críticas, esquecem outros atributos territoriais, não apenas Estatais. Alguns reducionismos se atrelaram à noção exclusivista de território e, “[...] para a maior parte das ciências sociais contemporâneas, o conceito de territorialidade é diretamente vinculado às práticas territoriais dos Estados-nação e tende a ocultar outros tipos de territórios, como os territórios sociais." (LITTLE, 2004, p.257258).

Para Antonio Carlos R. Moraes (2014, p.33) há uma clara dupla tradição disciplinar, compreendendo diferente a definição de território. Com entendimento de maneira diversa, há para ele, as trajetórias de reflexão geográfica e antropológica. "No campo da geografia, assim como nas teorias do direito a afirmação de uma autoridade e o exercício do poder define o território, que é um espaço qualificado pelo domínio político." (MORAES, 2014, p.33). Segundo esse mesmo geógrafo, “Já nas teorias da antropologia, tal conceito qualifica a vivência de espaços específicos e a espacialidade de relações simbólicas, notadamente aquelas referidas às identidades." (MORAES, 2014, p.33). Para Renato Ortiz (1996, p.51), “Geógrafos e antropólogos partilham, portanto, da ideia de que as culturas se enraízam em um meio físico determinado.”

Rogério Haesbaert (2005), não articula noções de território necessariamente aos debates disciplinares, embora ele dê a entender como campos de saberes e suas

\footnotetext{
${ }^{21}$ Não é viável separar esquematicamente e apenas em oposições, abordagens realizadas nas pesquisas de estudiosos da Antropologia e da Geografia. Muitas noções atribuídas a uma ou a outra são realizadas fora e dentro delas. Há encontros, divergências, mútuas inspirações e diálogos, como fez em um texto Marcelo J. Lopes de Souza (1995) "O território: sobre espaço e poder. Autonomia e desenvolvimento". Nele, o autor faz crítica ácida, para ao final elogiar: "Infelizmente, contudo, a Antropologia, com seus conhecidos vícios disciplinares (predileção pelo 'desviante', despolitização do discurso, desapreço para com o aprofundamento da análise do Estado...), tem dificuldades para alcançar uma interpretação 'estratégica' dos problemas de sociedades complexas (conflitos sociais objetivos e suas causas, papel da produção do espaço enquanto variável essencial da reprodução do status quo) restringindo-se quase sempre, assim, a chamar a atenção, ainda que muitas vezes apenas indiretamente, para os limites do discurso objetivista e pausterizador das demais disciplinas." (SOUZA, 1995, p.82-83). (destaques meus).
} 
tradições também ajudam a conformar sentidos diversos aos conceitos da expressão e do que venha a ser discussão territorial. $\mathrm{O}$ autor assinala não ser muito fácil e nem prudente tentar separar as dimensões do espaço social, porque é da sua possibilidade condensar e expressar multiplicidades de elementos. Compreendendo a seguir citadas, por mim sublinhadas quatro abordagens gerais, segundo elencou Rogério Haesbaert (2005, p.35):

[...] uma que parte da noção de território como dimensão físico-econômica da vida humana, outra que vê o território como base de ordenamento político da sociedade; uma terceira, que parte da ideia de território como espaço de identificação cultural; e uma quarta, a mais totalizadora, que vê o território como uma espécie de "experiência integral" do espaço pelos grupos sociais.

Essa última noção das quatro (acima) descritas por Haesbaert (2005, p.35), parece guardar maior feição com a ideia de Milton Santos como se nota na citação a seguir; enquanto a segunda (a do ordenamento político) parece mais característica da concepção de território de Antonio Carlos R. Moraes.

O território foi tomado como elemento definidor de uma era, por assim dizer, pós desencantamento do mundo e, principalmente para Max Weber (2003; 2004), para quem parte fundante do conceito de Estado Moderno é visto como monopólio da violência em uma delimitação determinada. ${ }^{22}$

Há resistências, na promoção do território Estatal nacionalista, quando da expansão imperialista, por exemplo, ou mesmo chegando aos dias de hoje, em tempos de globalitarismo. Volto às horizontalidades de Milton Santos (2000; 2004), para perguntar não teria tentado em sua obra última (publicada inédita em vida), articular um conceito mais abrangente possível de território (na classificação anterior citada de Haesbaert, "experiência integral"), incluindo tantos aspectos quantos possíveis? Ao que tudo indica a resposta é positiva! Na citação a seguir, é possível encontrar a intenção de Milton Santos que vem acompanhando parte das obras do cidadão do mundo, em tentar abarcar o máximo possível das palavras que expressam a complexidade envolvendo os usos dos territórios em uma brincadeira dialética de síntese (território Estatal + territórios sociais):

O território não é apenas o resultado da superposição de um conjunto de sistemas naturais e um conjunto de sistemas e coisas criadas pelo homem. $\mathrm{O}$ território é o chão e mais a população, isto é, uma identidade, o fato e o sentimento de pertencer àquilo que nos pertence. O território é a base do

\footnotetext{
${ }^{22}$ Renato Ortiz (1996, p.12) validou essa discussão ainda como pertinente e não findada, "[...] o Estado-

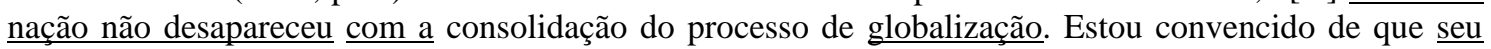
papel é fundamental em diversos setores, como o monopólio da força." (destaques feitos por mim). Em Benedict Anderson (2005, p.22) a globalização não findou com as estratégias nacionalistas: "A realidade é muito clara: o 'fim da era do nacionalismo' há muito profetizado, não está nem remotamente à vista."
} 
trabalho, da residência, das trocas materiais e espirituais e da vida, sobre os quais ele influi. Quando se fala em território deve-se, pois, de logo, entender que se está falando em território usado, utilizado por uma dada população. Um faz o outro [...]. (SANTOS, 2004, p.96).

Nesse trecho de Santtos (estou considerando a classificação totalizadora da “experiência integral" de Haesbaert 2005, já citada) parece estar a capacidade de, na mesma ideia, abarcar tanto os territórios dos Estados nação, como também aquelas territorialidades de pertencimento e de identidades, construídas culturalmente por grupos e indivíduos - aqui tomado de empréstimo a noção de territórios sociais, de Little (2004). Esses territórios sociais (co)existem, não apenas nas elaborações mentais e intelectuais. Negar a existência de outros territórios ${ }^{23}$ em paralelo e convivendo (menos em harmonia e mais em tensões com o mercado e) com o território Estatal é uma característica muito presente ao longo da história (até recente!) do Brasil; como discuto a seguir.

\section{O Brasil como território. O território como Brasil}

Estou de acordo com interpretações que percebem como, durante vários contextos e momentos, recusou-se e tentou-se impedir a reprodução de áreas autônomas, "independentes" e auto-gestadoras do Brasil pela própria população. ${ }^{24} \mathrm{Um}$ histórico pouco tolerante com territorialidades sociais e forte na gestão centralizadora do território pátrio. Quilombos, Canudos, Contestado, seriam exemplos? Resistências de territorialidades sociais e coerção de homogeneidade territorial Estatal. Antonio Carlos R. Moraes (2001), considera um exemplo de extraterritorialidade:

O episódio de Palmares foi minimizado na história brasileira. Primeiro, vale lembrar que Palmares durou quase cem anos, um século. No seu auge, por volta de 1650 , chegou a ter 70.000 habitantes, que era mais ou menos a população da área mais povoada da colônia, na época, o Recôncavo Baiano. Então não foi

\footnotetext{
23 "A modernidade é, talvez, a primeira civilização que faz da desterritorialização o seu princípio. Ela é descentrada, privilegiando a deslocalização das relações sociais." (ORTIZ, 1996, p.68). Excelente contraponto da discussão acerca da mundialização na obra de Renato Ortiz (1996). Ele busca articulações multidisciplinares de maneira a escapar de significados estritos de conceitos; afirma: "O desenraizamento é uma condição de nossa época, a expressão de um outro território." (ORTIZ, 1996, p.69).

${ }^{24}$ Faço paralelos da existência de territórios sociais, no caso paradigmático de Canudos, ressaltando não ter sido exclusivo, isolado ou único. Berthold Zilly (2000, p.314) lembra: "Esse Estado em miniatura dentro do Estado, situado no interior inóspito da Bahia, pode ser considerado uma iniciativa de auto-ajuda relativamente bem-sucedida de vítimas da civilização e da modernização, um movimento transformado em organização que conseguia satisfazer sofrivelmente as necessidades básicas dos seus moradores e os libertava da habitual opressão por parte de fazendeiros e autoridades. Se as condições de vida em Canudos não fossem pelo menos um pouco melhor do que em outros povoados da região, não seria possível explicar o forte movimento migratório rumo ao arraial, com talvez uma centena de habitantes em 1893, crescendo vertiginosamente para dez ou talvez vinte mil até meados de 1897 [...]."
} 
uma coisa secundária. Palmares foi uma clara situação de extraterritorialidade no domínio português, era um Estado autônomo, que inclusive negociava com portugueses e holandeses. (MORAES, 2001, p.110) (destaques meus).

Movimentos sociais rurais foram bastante reprimidos no Brasil como Bertold Zilly (2000) ratifica, nesse exemplo: "Sem dúvida, a comunidade de Canudos lesava o monopólio estatal da violência [...].” (ZILLY, 2000, p.314).

Não é mero acaso, o Brasil, com sua área total ter um histórico de conflito e acesso desigual fundiário tão marcante. Projetos sociais autônomos viáveis, foram muitas vezes vistos com desconfiança ou perigosamente alternativos; tradicionalmente tentou-se combater ou negando-lhes entendimentos e existências em seus próprios termos. Recusou-se, em sua época, atenção, por exemplo, de ter havido em Canudos, "[...] práticas democráticas como o uso comum do solo e dos rebanhos, assim como uma espécie de mutirão, tudo em caráter voluntário, pelo menos em tempos de paz. Havia escola e um rudimentar serviço de saúde.” (ZILLY, 2000, p.318). Negar a existência de agência própria da maioria da população, velha baixa estima destinada ao Outro pelos que estão acima, na cúpula da pirâmide social brasileira, reforça a invisibilidade dada a partes integrantes do povo do País. ${ }^{25}$ Ainda em Canudos, vale exemplificar, “[...] havia até uma 'rua da Professora'. Esses traços”, diz Berthold Zilly (2000, p.314) do corrente desprezo ao popular no Brasil, "não mereciam muita atenção entre os seus primeiros cronistas [sobre Canudos], ligados à civilização inimiga." (ZILLY, 2000, p.314). Via-se em Canudos, território da barbárie.

Combateram-se, na primeira República, comunidades com modelos sociais autônomos, e como “[...] não existem sociedades não espaciais (se bem que existem sociedades não territorializadas)" (MORAES, 2014, p.25), o Estado em seu monopólio da violência procurou colocar fim a tais territórios: Quilombos em época colonial e continuando na República. Na busca de deslegitimação de territórios sociais, justamente pelas ações e atitudes de protagonistas, estes foram tratados como desviantes ou inimigos e mesmo integrante do território do País deveriam ser incorporados ou eliminados:

Antonio Conselheiro e seus seguidores tinham de fato algo dos heróis antigos: eram - durante poucos anos - fundadores bem-sucedidos de uma cidade autônoma, a maior das redondezas, um mini-Estado alternativo, que defendiam contra as agressões do mundo inteiro, uma comunidade onde os humildes

\footnotetext{
${ }^{25}$ Um exemplo sobre século XIX no Brasil: "Mas a percepção da elite imperial estava permeada por uma ambiguidade, ou uma duplicidade: a elevada imagem que fazia de si mesma não tinha correspondência na imagem que fazia do país. A elite brasileira se considerava uma parte da civilização europeia condenada aos trópicos. [...] implicavam um programa de ação - civilizar o Brasil.” (MAGNOLI, 1997, p.95)
} 
gozavam de mais respeito e dignidade do que em outras partes da hinterlândia brasileira. Fossem as elites menos arrogantes, menos bárbaras, mais respeitosas da legalidade, mais dispostas ao diálogo, os canudenses poderiam ter sido cofundadores de um Estado diferente, menos injusto, menos excludente, mais moralizado, mais civilizado, cuja configuração exata, porém, é impossível imaginar, não se podendo descartar o perigo de aberrações fundamentalistas. (ZILLY, 2000, p.338-339). (destaques feitos por mim)

Há sim, estratégias diversas e mesmo lutas dentro de território pátrio, expressos, por exemplo, nas formas de apropriação, uso e gestão da terra, constituidoras de diferentes territorialidades. Em uma abordagem teórica, se há um tipo ideal ${ }^{26}$ do território Estado nação, há também conceitualmente, o tipo ideal dos territórios sociais (LITTLE, 2004). Múltiplas formas de apropriação e diferentes regimes de propriedade podem ser exemplos de assimétricas coexistências territoriais, mas que em última análise precisam ser toleradas pelo Estado nação para permanecerem. ${ }^{27}$ Séculos de ocupação efetiva apresentam um peso histórico importante, por exemplo, aos povos tradicionais, como argumenta Paul E. Little (2004, p.265) "O fato de que seus territórios [dos autóctones] ficarem fora do regime formal de propriedade da Colônia, do Império e, até recentemente, da República, não deslegitima suas reivindicações, simplesmente as situa em uma razão histórica e não instrumental [...]”.

Recentemente tem aparecido em algumas denominações de políticas públicas do governo federal, a entrada de jargão e pronunciamentos por parte de agências oficiais do Estado (como das secretarias do Ministério do Desenvolvimento Agrária/MDA), atributos do território como pertencentes a coletividades civis, comunidades ou às sociedades locais/regionais. É o caso das políticas públicas voltadas aos mais de 5.000 municípios rurais do País, visando entre outras, a implementação de infra-estruturas e assentamentos no campo, enfim, de investimentos públicos da agenda de governo (SABOURIN, 2015). Tais programas existentes ou mesmo extintos, levam a expressão território em suas denominações, tais como, "Programas Territórios da Cidadania"/PTC; "Programa Nacional de Desenvolvimento Sustentável de Territórios"/PRONAT ou ainda, "Planos Territoriais do Desenvolvimento Rural Sustentável".

\footnotetext{
26“"Em todos os tempos, os agrupamentos políticos mais diversos - a começar pela família - recorreram à violência física, tendo-a como instrumento normal de poder. Em nossa época, entretanto, devemos conceber o Estado contemporâneo como uma comunidade humana que, dentro dos limites de determinado território - a noção de território corresponde a um dos elementos essenciais do Estado reivindica o monopólio do uso legitimo da violência física". (WEBER, 2004, p.56).

27 “[...] entidade territorial do Estado-nação impôs-se sobre uma imensa parcela da área que hoje é o Brasil, de tal forma que todas as demais territorialidades são obrigadas a confrontá-la." (LITTLE, p.257).
} 
Pela nomenclatura nas justificativas para as escolhas das nomeações de tais programas e, na aplicação de políticas públicas mais participativas (SABOURIN, 2015), tem se apresentado planos em que protagonistas de pretensos territórios são, as pessoas, movimentos sociais (ou seus líderes) ou prefeituras dos pequenos municípios do interior ou agentes sociais do campo.

Algumas dessas políticas públicas desejam atingir ações transversais, demarcando problemas que ocorrem (e atravessam) áreas de diferentes municípios. Havendo busca de soluções comuns, para questões não restritas, o Estado alocaria preferência de políticas públicas especificas (não apenas setoriais). O ponto positivo estaria em buscar resoluções de problemas com noção de dinâmica sócio-espacial. Mesmo que em tais políticas (algumas já citada) se nomeiem como territoriais, talvez, em termos conceituais, seja "região" mais apropriado para nominar algumas dessas ações; nada grave, afinal, propõem atravessar fronteiras de (territórios de) municípios.

Mas, para alguns analistas desses programas que incluem a palavra território no nome das políticas públicas, a crítica feita ao Estado é que, ao difundir a expressão território, busca representar o desenvolvimento de comunidades (particularmente rurais, nesses casos). Então, questiona-se: não estariam esses projetos, domesticando expressões mais candentes ou polêmicas, em um País marcadamente desigual? A palavra território, nesses casos, estaria sendo usada em substituto, por exemplo, da nomeação de outros conflitos (territoriais) como questão agrária/reforma agrária, "latifúndio" ou para (não) designar a concentração da posse da propriedade da terra? Tais temáticas aparentemente desaparecidas do dicionário político-social recente do campo no Brasil, permanecem recheadas por nomenclaturas territoriais. Ainda no calor da hora de políticas públicas com menos de uma década de aplicação, já surgem críticas ao uso do termo território contra o social. Embora, ao mobilizar a expressão se deseja tão somente (e com ressalvas) o desenvolvimento de espaços delimitados em áreas rurais especificas do País, abarcando para tanto, participação de atores sociais, como os movimentos sociais do campo. Mas, a inserção de um jargão: território, parece vir acompanhado de adocicar e adormecer planos significativos de maior acesso à propriedade da terra (PORTO, 2015). É preciso politizar o uso do conceito de território.

Para Paul Little (2004), na virada dos séculos XX para XXI, outros projetos vindos do Estado, destinado ao norte do País, tais como o "Sistema de Vigilância da Amazônia"/SIVAM ou o "Zoneamento Ecológico-Econômico"/ZEE, foram exemplos da razão instrumental do Estado com sua noção de soberania exclusivista. 
Caracterizando, uma gestão centralizada e militarizada, para não dizer autoritária do território do País, sem levar em conta a existência das pessoas. Negava-se, segundo o autor, o pluralismo e autonomia dos indivíduos diretamente envolvidas ou que sofreriam impactos da implementação das políticas. O apelo muitas vezes à segurança, nesse caso, reduz diretamente a participação das pessoas na apropriação ou gestão territorial como, por exemplo, no "[...] programa bilionário que utiliza a alta tecnologia de espionagem para 'vigiar' a Amazônia brasileira de 'cima'.” (LITTLE, 2004, p.278). O uso desigual do território brasileiro tem uma longa trajetória.

Espaço barganha. Política e território, caso da criação da Província do Paraná, 1853

$\mathrm{Na}$ história dos atributos, concepções e ideologias geográficas do território brasileiro é válido apontar como o espaço foi sistematicamente utilizado como moeda. Seja em trocas e ganhos políticos como apropriação de áreas, seja na intenção de domínio de pessoas, das esferas de administração e da capacidade de ter influências no Estado. No século XIX durante o Segundo Reinado (D. Pedro II), por exemplo, foram criadas apenas duas províncias no Brasil: Amazonas e Paraná. Já houve quem afirmasse como as justificativas para criação dessas províncias não levava em conta a opinião da população, mas "interesses essencialmente eleitorais de grupos políticos estranhos à terra." (GREGÓRIO, 2009, p.3036). Segundo pesquisadores da temática, a maioria do Parlamento do Império representado pelas províncias existentes, quase nunca desejava ver ampliado o número de políticos, pois significaria partilha de recursos e influências:

[...] a decisão sobre a criação ou não de novas províncias no Império dependia de debate e aprovação do Parlamento central, o que obrigava a que, para ter seus interesses atendidos, as elites regionais lograssem transformar seus projetos em políticas de interesse nacional. (GREGÓRIO, 2009, p.3043).

Dificilmente era possível convencer membros do parlamento a votarem favorável à criação de novas províncias, pois na visão deles, isso resultaria em aumento do número de parlamentares e, portanto, ampliação de concorrentes nas decisões do Império. Outros fatores foram mobilizados para o sucesso na passagem de comarcas para províncias autônomas; emancipação quase sempre realizada com vistas aos ganhos e pressões das elites regionais. Os representantes políticos das províncias por não desejarem ver o poder parlamentar pulverizado e ampliado os competidores por 
recursos barravam ou eram sistematicamente contrários à elevação de comarcas em novas províncias. ${ }^{28}$

Já dentro da política dos conservadores, o discurso favorável a gerar novas unidades provinciais estava focado na integração. A intenção de "junção" era com sentido de aproximar o que se considerava áreas distantes da administração do Império, sediado na Corte no Rio de Janeiro, para, em consequencia, exercer melhor o domínio, o controle e, claro, evitar a temida fragmentação. Destaco como: "A relação entre território e poder político era direta [...]." (GREGÓRIO, 2015, p.336). Para Gilmar Arruda (2008, p.99):

A historiografia aponta, quase que consensualmente, como motivo para o desmembramento da província do Paraná, uma estratégia do Partido Conservador, então no poder, para impedir ou mesmo criar uma barreira para as crescentes insatisfações políticas no sul do país, especialmente no Rio Grande do Sul. (ARRUDA, 2008, p.99).

Segundo Vitor M. Gregório $(2009 ; 2015)$ foram bem sucedidos àqueles que associaram (ou amarraram uma articulação de) projetos e discursos de criação de províncias aos interesses difundidos como nacionais, e que poderiam comprometer a segurança do conjunto maior, tais como as contestações políticas, particularmente de cunho separatista. Segundo o autor, a estratégia mobilizada para convencer sobre a criação da província do Amazonas, foram usados os exemplos da Cabanagem, das disputas de fronteiras com Inglaterra, França, além do histórico "cuidado" da navegação no rio Amazonas. Mesma tática foi invocada na bem-sucedida "passagem" da $5^{\text {a }}$ Comarca de São Paulo, em Província do Paraná, onde foram apontadas a Revolução Farroupilha $^{29}$ no Rio Grande do Sul (que buscava expandir área de atuação agregando descontentes), a revolta Liberal de São Paulo, a navegação da bacia platina e outras

\footnotetext{
28 “[...] criação das províncias do Amazonas e do Paraná foram os únicos a alcançarem êxito no período imperial exatamente porque os grupos políticos dominantes destas duas regiões lograram articular seus interesses com questões mais abrangentes - como os problemas relativos às fronteiras e aos movimentos armados - consubstanciando-os, assim, em interesse nacional. Algo que os demais grupos com interesses emancipacionistas não conseguiram realizar." (GREGÓRIO, 2009, p.3044). (destaques meus).

${ }^{29}$ Silvio Coelho dos Santos (2007, p.23) fez assim, panorama do RS: "O Sul do Brasil foi teatro de várias guerras. Em 1835, devido a dissensões políticas internas, irrompeu no Rio Grande [do Sul] a Revolução Farroupilha. Os revolucionários intentaram a separação do resto do País, advogando uma estrutura republicana de governo. As ideias libertárias passavam pela constituição de um Estado democrático, que não era de interesse do Império. Durante dez anos correu sangue. A unidade do País, entretanto, prevaleceu. Mas os tempos de guerra não haviam terminado. Lutou-se contra Rosas e Oribe, na Argentina e no Uruguai. Depois, aconteceu a Guerra do Paraguai. Toda essa movimentação armada afetou a Região Sul, em particular o Rio Grande, pelo desenvolvimento de um forte sentimento de nacionalidade."
} 
tensões com países vizinhos nessa região. Estes aspectos foram levantados como legitimadores do Paraná tornar-se uma província autônoma, emancipando-se de SP.

Entre apresentação do projeto, aprovação e implementação demorou aproximadamente uma década para a chamada $5^{\mathrm{a}}$ Comarca tornar-se Província do Paraná. Assim, esses casos do Amazonas e do Paraná podem ilustrar como “[...] apenas condições excepcionais, como levantes armados, invasões de fronteiras, questões internacionais de grande importância, foram capazes de atrair a simpatia dos membros do Poder Legislativo para a causa da criação de províncias.” (GREGÓRIO, 2009, p.3043). Tais aspectos, reforçam a interpretação do Brasil como um território para governar interesses de domínio. ${ }^{30}$

Concepção espacializante do Brasil, como sinônimo de seu território é que teria contribuído para impedir uma maior recepção da nação, barrando a capilaridade nacional participativa a respeito das decisões coletivas dos usos do território. Mas como haveria de ter nação, recusando acesso mais igualitário, equilibrado e afetivo de pertencer ao País? A ideia de jogo político e econômico na emancipação das províncias, por exemplo, reforça essa concepção do uso espacial como elemento de monopólio para alguns, quase sempre uma elite regional articulada.

Historicamente, não se promoveu representação das diversificações sociais de acessos às terras no País, pois isso poderia ampliar noções de povoados territorialmente resguardados, assim como a desigualdade do acesso ao solo. Ao negar-lhes cidadania, negava-se, também, existência de seus espaços. Ou vice-versa, ao negar-lhes existência territorial se lhes cassava a existência cívica. Mesmo se resistindo, como na bem captada expressão territórios sociais, só pode ser entendida tal expressão, surgida do conflito. O que fica mais claro nos exemplos apresentados por Paul Little (2004, p.279):

Também é importante indicar que ainda existem setores das Forças Armadas do Brasil que promovem um nacionalismo exclusivista, cuja expressão mais nítida talvez tenha sido sua oposição à demarcação e homologação das terras indígenas. Em razão dessa situação, os povos tradicionais esforçam-se por mostrar que seus territórios, à diferença de territórios étnicos em outras partes do mundo, não representam uma ameaça ao Estado brasileiro. Não possuem fins separatistas, não guardam exércitos próprios, consideram-se cidadãos brasileiros. O que procuram é o reconhecimento de seus territórios e do modo

\footnotetext{
${ }^{30}$ Buscava-se atingir maioria no Legislativo na permissão da criação de "novas" províncias, pois "[...] a criação de províncias corresponderia à formação de novas instâncias autônomas com finanças e administração próprias, que mesmo subordinadas à Corte do Rio de Janeiro possuíam capacidade de elaboração e implementação de políticas específicas. Este elemento, somado ao fato de que uma nova província garantiria às elites regionais a eleição de representantes próprios no Parlamento central, geraria nesses grupos sociais grande interesse em contribuir para a criação destas novas instâncias administrativas e, sempre que possível, garantir seu controle sobre elas.” (GREGÓRIO, 2009, p.3043). (destaques meus)
} 
de vida que construíram ali. Assim, surgem conflitos quando os povos tradicionais reivindicam os próprios espaços culturais, políticos e territoriais no aparelho único do Estado, principalmente quando confrontam não a legitimidade do Estado como tal, mas o nacionalismo homogeneizador promovido por alguns dos seus setores. Em última instância, o que esses grupos reivindicam são seus direitos - como cidadãos e como povos - sem questionar a legitimidade do Estado brasileiro. (LITTLE, 2004, p.279). (destaques meus)

Milton Santos (2004), com ironia, aponta a teimosia como forma de reprodução social no Brasil daqueles cuja experiência de viver na escassez é larga: horizontalidades dos espaços banais. Little chama atenção à "persistência cultural" como maneiras e garantias da força da continuidade de grupos subalternos ou minorias, constituindo o que ele denominou de territórios sociais.

Antonio Carlos R. Moraes, interpreta a consolidação do "Estado nação Brasil" pelo usos e imposições de uma narrativa única de território, como projeto que sequiestrou outras possibilidades de constituições, afirma como, por exemplo, a geografia foi utilizada na promoção de uma ideia força de construção territorial do País, como sinônimo de brasilidade. Tal ideologia se torna ativa - vitoriosa - quando silencia, impede ou se sobrepõe a comunidades prévias, essas retratadas como inexistentes ou inoperantes (por isso o título do tópico anterior: O Brasil como território. O território, como Brasil):

Com a emancipação política de 1822 era necessário consolidar o novo Estado nacional, numa situação em que quase metade da população era constituída de escravos: nas dificuldades de identificar-se com uma nação, o Estado brasileiro toma o território como centro de referência da unidade nacional, vendo seu povoamento como a tarefa básica realizada no processo de construção do país. Tal concepção espacialista enraíza-se na cultura política do Brasil estimulando argumentação de forte conteúdo geográfico que adentra pelo século $\mathrm{XX}$, fundamentando algumas das principais interpretações do país nas primeiras décadas republicanas. (MORAES, 2005 p.33) (destaques meus)

Como se "para fazer" o Brasil não houvesse gente capaz, nem culturas e vida social, ou comunidades válidas e dignamente pertencentes. Como tocar um País com um povo desqualificado, na visão fatalista das elites? Seria a existência do substrato físico legitimador - pelos atributos da natureza - do processo em eterna construção do território; imaginando o Brasil como algo inacabado. Fazer o País andar, nessa lógica, significaria agregar mobiliários, realizar obras e erigir próteses: discursar do seu valor. O desprezo e desconfiança ${ }^{31}$ da elite com "seu" povo (seu em sentidos contraditórios:

\footnotetext{
${ }^{31}$ Embora a partir de fins do século XIX, visões deterministas tenham sido adotadas no Brasil em um momento de crítica às teorias raciais (e até usada para tanto), a culpa é ameniza às pessoas e passa a recair ao meio e lugares "inóspitos" em que se inserem. Nessa interpretação, o que passa explicar a "letargia" e
} 
pois necessitavam do uso da força de trabalho, mas cuja tutela queriam garantir, além de silenciarem suas vozes) achata hegemonicamente a nação, como sinônimo de exclusivismo territorial. O Brasil como área-recurso, matérias-primas, sertões, enfim, como espaços opaco. Não uma nação comunitária, mas conquistada, explorada, colocada como meta de produção. Um País de imensos vazios demográficos. Nessa lógica, territórios sociais seriam empecilhos, problemas e impedimentos a serem retirados do caminho do território formal. ${ }^{32}$

Mobilizo para a presente pesquisa a abordagem que trata de compreender processos de construção territorial do Estado-nação, embora sabendo da (co)existência das horizontalidades guardadas nos territórios sociais, que, enfim, não se pode recorrer no vício de desprezá-las. Nesta escolha é preciso estar atento e pontuando como, no caso do Brasil, utilizou-se de discursos sobre o território para implementar interesses políticos via ideologias geográficas. Parte dos sentidos dessa "lógica territorialista" da ("débill") nacionalidade e das ações do Estado brasileiro, parecem herdadas de tempos coloniais, como discutirei a seguir no caso de Santa Catarina.

\section{A localização da capital em uma ilha: "rugosidade" e longa duração na relação com a montagem territorial catarinense}

No contexto a partir da invasão europeia e da invenção ou construção moderna da América Portuguesa (ou ainda, para os portugueses, "achamento do Brasil"), passouse a dar um certo tipo de uso bastante central para uma ilha do Atlântico Sul, local ou localização tornada, inicialmente, parada de viajantes nos mares do sul. Iniciou-se, ali, o que estou denominando como territorialidade marítima. Foi deixando de ser mero lugar: mais do que um fixo e ponto de passagem na paisagem. Na camada seguinte do tempo social, as relações políticas entre Portugal e Espanha na América reforçaram, os fatores locacionais a/na mesma, em sentido de torná-la uma sede. Passou a ter no século XVIII uma territorialidade militar. Sediadora e sedenta de decisões, lócus de governabilidade e

\footnotetext{
demais aspectos negativos da população, seria sofrerem impactos diretos dos espaços de sustentação. Segundo Antonio Carlos R. Moraes (1991, p.170) no contexto de início da República: "É um período de muitos ensaios que tematizam a tarefa das elites - a construção do país -, questionando bastante 'o povo do que dispomos para realizar tal tarefa'. Observa-se claramente nesses escritos a visão do país como um espaço a se ganhar, sendo sua população apenas o veículo de tal ação.” (MORAES, 1991, p.170).

${ }^{32}$ Relação de estabelecimento de jurisdições dos espaços e acordos para delimitações continua ocorrer ainda muito tempo depois do Brasil se tornar independente: "O processo de expansão de fronteiras que marcou a história territorial do Brasil colonial e imperial continua ainda hoje [...] de tal forma que podemos falar de uma situação de 'fronteiras perenes'." (LITTLE, 2004, p.266)
} 
morada da direção e de atores Estatais (militar) influentes. Fixos e cabeça de agente do Estado colonial, na periferia. Lugar de mando e manobras; periférica, sim, e tipo de centralidade de defesa e de alargamento de fronteiras.

Continuando esse primeiro capítulo, buscarei apresentar duas variáveis principais: a) a colocação da ilha na rota das comunicações marítimas pelo seu uso por viajantes (como se percebe através de alguns relatos desses) e; b) emergência da Ilha como governança, resultado das decisões geopolíticas e ação (colonial) da metrópole. Ambas marcam a influência direta na geohistória da construção territorial catarinense.

Considero pertinente também propor uma sugestão - embora, com certo caráter ensaísta, mas não apenas - dentro desse quadro de constituição territorial. Na origem da escolha há uns três séculos atrás de uma ilha, entre outras opções disponíveis nas beiras de mares, como representação de certo poder metropolitano, de onde e até os dias de hoje, está a capital ${ }^{33}$ do Estado de Santa Catarina. A escolha tem aspecto de territorialidade militar, mas precedeu pela adensada utilização por embarcações (configurando forte uso marítimo); aliás, não se trata apenas de ciclos como se fosse ora marítimo e em seguida, apenas militar, mas sim de convivências, enquanto ascensão de uso militar, a ilha manteve papel de apoio nas rotas de navegação. São essas características do tempo social que a fundam como um tipo de sede.

Não é possível tratar dos elementos geohistóricos constituintes do território e de regionalismos de Santa Catarina sem deixar de tratar também de sua capital. Entendo como a decisão e escolha da sede governativa e sua fortificação (na primeira metade do século XVIII) fizeram parte do contexto de disputa Ibérica, e, principalmente, do interesse de domínio português. ${ }^{34}$ Maior imposição do poder real, significando ampliação do domínio, da vigilância e do controle português, deu início ao "território de

\footnotetext{
${ }^{33}$ No livro Segurança, Território, População, Michel Foucault (2008, p.20) diz: "Em todo caso, a cidadecapital é pensada [...] em função das relações de soberania que se exercem sobre um território."

${ }^{34}$ No século XVI o poder da metrópole portuguesa teme franceses, holandeses e indígenas, a partir da década de 1540 exerce uma política territorial mais firme, em Santa Catarina dois séculos seguintes, no setecentos, portanto, a coroa torna a centralizar o domínio, como tratarei. Ressalto na América portuguesa “O momento de fundação da colônia não foi de maneira alguma o ano de 1500 e de seu 'achamento', mas a implantação administrativa na Bahia de Todos os Santos e a definição de um projeto civilizatório. É possível visualizar com nitidez a mudança de postura da Coroa portuguesa quanto ao Brasil no Regimento de 17/12/1548, outorgando a Tomé de Souza, primeiro governador-geral. Não se trata mais de aproveitar dos jardins do paraíso, mas de tomar providências urgentes para ganhar uma guerra (que estava sendo parcialmente perdida) contra os indígenas e seus eventuais aliados franceses." (OLIVEIRA, 2010, p.18). Controle e busca por estruturas gerou maior valorização dos espaços: "Na América portuguesa, em consequência da ofensiva e de declínio do trato asiático, foram tomadas em 1543 medidas para o povoamento e a valorizacão do território. Quinze capitanias hereditárias acabaram sendo cedidas a donatários." (ALENCASTRO, 2000, p.20) (destaques meu)
} 
Santa Catarina”, na expressão da época: uma praça militar. Defendo a característica de sua base territorial herdada não apenas a emergência de Santa Catarina, mas o local da capital. É possível apontar momentos da ilha no início de atratividades.

Resultando de presenças até hoje visíveis de registro da época de sua escolha como sede do poder, como em (algumas ruínas) fortalezas/fortificações, traços e resquícios na arquitetura e casaril colonial e, talvez até mesmo em parte, herança na fala e linguagem ${ }^{35}$ do dialeto local? Estou entendendo a própria permanência da sede da capital na Ilha até agora no século XXI, como uma longa e permanente rugosidade, que afinal, o tempo demora a gastar; como diria Fernand Braudel (1989, p.25), “[...] a terra, como nossa pele, está condenada a conservar as marcas das antigas feridas." A sede política governamental do Estado catarinense em uma ilha, uma ferida, enrugada: iniciada como uma governança, militar.

\section{E o que é uma rugosidade? Milton, explica. Uma ilha e seus usos: permanências}

Milton Santos ensina; quando a duração da construção ultrapassa ao tempo social em que foi construído, temos uma ruga: "As rugosidades são o espaço construído, o tempo histórico que se transformou em paisagem, incorporado ao espaço." (SANTOS, (2002, p.173). Vestígios (inertes ou aparentemente inertes) de "estágios" anteriores, transmitidos; são resistências, permanências e expressões de uma conjuntura ou de um modo de produção não mais existentes - ou, criadas em outra época - as rugas nos espaços não são de hoje... intervenções vindas de tempos pretéritos, suas funções e seus usos cotidianos podem continuar as mesmas ou sofrerem alterações. São bases dadas, com atributos antigos, refuncionalizados. Quase sempre suas formas denunciam o período das suas criações, assim como as mesmas formas podem influenciar nos seus usos sociais, mas não determinam. A forma não determina a função (nem vice-versa), é o tempo quem a fará continuar e dirá dos novos atributos ou usos constantes e regulares.

\footnotetext{
${ }^{35}$ Falares, sotaques, pronuncias e maneiras dos dizeres são constantemente modificados ("a língua é viva"). Caberia pensar nas possibilidades de testemunhos ou rugosidades não apenas nos espaços, mas também nas gramáticas de enunciações e expressões antigas dos dialetos / nas formas das falas, por exemplo? Para autores locais, em uma abordagem de corte positivista, parte relevante de sentidos culturais de Santa Catarina estariam originados da época colonial: "A imigração açoriana e madeirense para a costa de Santa Catarina, a partir de 1748, mormente para a Ilha sede da Capitania, em número superior aos habitantes que ali se encontravam, não só contribuiu significativamente para a multiplicação da população, como também emprestou à terra características básicas da sua cultura, dando à gente catarinense uma feição que permanece até os dias atuais." (CORRÊA, 2007, p.p.79). (destaques meus)
} 
Uma rugosidade é em parte, a utilização de uma dada construção diferente ao destino a ela atribuído quando a originou, ou seja, uso de sua função é alterada, mesmo precisando adaptar, parcialmente, a forma. Sua função não precisa necessariamente mudar. Mas a forma da construção poderá caracterizá-la como uma espécie de ruga; permanece a estrutura, originada em outro tempo social, usando-a diferente ao previsto.

Usos atribuídos podem modificar-se, sobre as (mesmas) formas já existentes. ${ }^{36}$ Mas não há regras quanto ao que deve ser ou deixar de ser: tanto as formas e as funções; vale permanecer para existir. As relações sociais, as interdições, os hábitos, os poderes, enfim, a cultura e a sociedade criadora de algumas formas espaciais fixas podem até ter desaparecido (e desaparecem), mas, "sem que tais formas fixas desapareçam." (SANTOS, 2002, p.173). Por conseguinte, podendo existir várias rugas originadas de diferentes épocas alocadas um mesmo espaço, Milton formulou a ideia da existência de temporalidades convivendo: "dentro de um tempo existem tempos." (2002, p.22). Isso quer dizer, na linguagem miltoniana - se é possível de falar na existência de tal gramática - na expressão do espaço, pela paisagem, pode apresentar acumulações desiguais de tempo. Partilha mesmo espaço, rugas advindas de diferentes momentos: "Cada lugar combina variáveis de tempos diferentes. Não existe um lugar onde tudo seja novo ou onde tudo seja velho. A situação é uma combinação de elementos com idades diferentes." (SANTOS, 1997, p.98). Espaço um acumulado de tempos diferentes.

Em um diálogo retirado de autor contemporâneo da literatura de crônica e ficcção brasileira, Luis Fernando Veríssimo (2004, p.46), poderia ilustrar um pouco dessa discussão, como segue: “- Porque um edifício fica. Também envelhece e se deteriora, como as pessoas, mas fica. Continua onde estava durante toda a história. Fica para lembrar a história." Ainda do mesmo autor, "Mas um edifício fica. Para lembrar. Mesmo que não saiba bem o quê." (VERÍSSIMO, 2004, p.47). Acredito, talvez um bom trabalho atribuído aos geógrafos, esteja em explicar as existências desses edifícios, que por si mesmos não manifestam sentidos, não se expressam sem olhar que os interprete.

"A sociedade não se pode tornar objetiva sem as formas geográficas." (SANTOS, 2002, p.244). Para tentar tornar mais didático, claro e direto essa discussão, compensa retomar essa afirmativa de Antonio Carlos R. Moraes (2014, p.27): “Toda sociedade para se reproduzir cria formas mais ou menos duráveis na superfície terrestre

\footnotetext{
36 “Tem-se, portanto, espaços produzidos herdados, constituídos cada um (conforme a escala considerada) de formas pretéritas concentradas pontualmente na superfície da terra e por uma dinâmica natural, fatores que condicionam o uso dos lugares a cada conjuntura histórica considerada." (MORAES, 2014, p.27).
} 
[...]." São, em poucas palavras, essas formas existentes e duráveis na paisagem visíveis - as rugosidades. "Tais formas, que expressam uma quantidade de valor (trabalho morto) incorporado ao solo, substantivam na paisagem (congelam, em certo sentido) relações sociais específicas.” (MORAIS, 2014, p.27).

O que vai definir (re)existência, perpetuação, permanência e continuidade de algumas intervenções humanas/sociais no espaço, costuma ser proporcional ao valor atribuído. Se "determinado elemento"/edificação valer um valor em deixá-lo ali, em pé, fixo, permanente, não destruí-lo, sua continuação no tempo o tornará uma ruga, resistindo como "testemunho de um momento do mundo." (SANTOS, 2002, p.173). Às vezes deixam estruturas permanentes, por exemplo, por demandarem muito trabalho derrubá-las, ou substituí-las, assim, reutiliza-as (forma perpetua, na função que pode ser outra). Às vezes, abandonam-se construções, ficando marcas na paisagem, ou seja, novamente, rugas. Formas espaciais podem desaparecer e desaparecem, se considerado de baixo valor agregado da mesma (pouca disposição de trabalho e energia na sua construção); tenderá a ser eliminada, substituída e destruída, não possibilitando (re)existir, logo, se desagregado do espaço não se tornará uma ruga, desaparecendo como marca do tempo que a fundou.

O valor e a liquidez da edificação influenciam na constituição, ou não, da ruga: "A durabilidade no tempo de uma forma construída repousa em muito na quantidade de valor nela agregada, ou seja, na quantidade de trabalho despendido em sua construção." (MORAES, 2014, p.28). É formadora da rugosidade a capacidade de um atributo no espaço conseguir permanecer às mudanças sociais e dos tempos, dos modos de produção e das ressignificações de seus usos. Se é verdade que "O homem trabalha sobre herança" (SANTOS, 2002, p.174), tais heranças, em Geografia, são rugosidades.

Na reflexão de Milton, assim explicado por um comentador desse autor: "Enfim, a vivência social do espaço cria 'rugosidades' que duram mais que os estímulos e objetivos que lhes deram origem." (MORAES, 2014, p.27). É assim que penso então, uma sede de poder atribuída ou localizada na Ilha de Santa Catarina, pela sua longa permanência, uma ruga (com continuidades e rupturas). Vou tentar explicar porque defendo essa ideia a seguir, colocando essa rugosidade dentro da perspectiva territorial catarinense. Quero trazer ao palco essa discussão - colocar o dedo na ruga - debate que tanto geógrafos como historiadores em Santa Catarina têm realizado, principalmente pelas polêmicas em relação à desconfiança da localização da capital. Como se eu questionasse e tentasse explicar para você que aqui lê, a problemática: "Por quê é aonde 
é, a capital de Santa Catarina?" Defendo a tese, segundo a qual, parte relevante da resposta dessa questão está na própria emergência do território de Santa Catarina.

Baía(s) da ilha: navegar é preciso, parar é necessário. Quando o mar faz a ocasião

Nessa interpretação não esqueço, das escolhas, ou melhor, das estratégias e decisões na montagem dos territórios e também, teoricamente, quero alargar a própria noção de rugosidade. Não apenas para as benfeitorias, patrimônios (embora elas certamente tenham influenciado) e materialidades físicas continuadoras (trabalho morto, capital fixo), presente com as construções acumuladas e certa inércia imposta por mobiliários. As infra-estruturas arranjadas e modeladoras da paisagem podem constituir rugosidades, sim, as construções influíram, mas não só. ${ }^{37}$ Não apenas.

A escolha é sempre política e intencional de sediar o poder espacialmente, e geralmente envolve fatores de ordem estratégica, segurança, econômica, etc. Dos fatores que parecem ter sido usados como justificadores nas escolhas da Ilha de Santa Catarina, dois deles precisam ser ressaltados como fundadores de territorialidades: $1^{\circ}$ ) a localização da ilha e sua Geografia como apoio para embarcações, útil para um circuito movimentado no mar e; $2^{\circ}$ ) estar em um ponto estratégico para os interesses de Portugal, fazendo ali sediar um governo de defesa, tornando a Ilha de Santa Catarina uma Praça Militar, quando da criação da capitania subalterna (em 1738). Esses dois aspectos (locacional e geoestratégico) são importantes para compreender o caso da emergência catarinense, sendo sua base territorial. Dentro desses vetores à Ilha são é atribuídos papéis; (menos coadjuvantes e,) mais protagonistas, quando é constituída a territorialidade militar.

A realidade de um ecossistema, instituída pela existência física da Geografia de uma área, possibilita e informa racionalidades, convence e ajuda nas decisões. Embora tenhamos perdido de vista, é naquele contexto de uma circulação mercantilista e principalmente de reforço ${ }^{38}$ do controle do poder régio que ascendeu a decisão no

\footnotetext{
37 "O espaço social constitui-se, de um ponto de vista preliminar, em uma condição de realização de qualquer sociedade. Simplificadamente traduzível pelo binômio terra + benfeitorias sob a moldura das localizações específicas e da regionalização da produção, do consumo, do poder e das ideias, ambiente hominizado e culturalizado através do trabalho, ele é um suporte para as sociedades concretas, ou, para usar uma metáfora muito badalada entre estudiosos do Social, o 'palco'.” (SOUZA, 1988, p.24-25).

38 “[...] entre os séculos XVI e XVIII, houve - guardadas as particularidades de cada país - um processo crescente de centralização de poder das monarquias europeias. No caso específico de Portugal, verificamse a partir do reinado de Dom João V (1706-1750) políticas públicas de reforço da autoridade régia por meio de, entre outras medidas, submissão da nobreza e do clero ao reino e da reversão das capitanias
} 
século XVIII de no Atlântico aceitar ou, melhor, promover uma sede política à beira mar, o que ajuda a criar "[...] as cidades voltadas para o mar em locais importantíssimos do mundo da colonização." (SILVA, 2012, p.66).

Repito os dois contextos marcantes: a primeira camada seria o uso da ilha como um porto, ponto de parada nas rotas das viagens em uma dinâmica predominante até metade do século XVIII. A partir da fortificação e atração de famílias açorianas e madeirenses, mas principalmente, o contexto da criação da capitania subalterna da Ilha de Santa Catarina, a camada de uso atribuído a Ilha passa ser mais militar e de cunho estratégico na administração do espaço colonial português, como discutirei; passando a ter centralidade da gestão do território e não apenas, porto para uso das embarcações.

A respeito de Salvador e Rio de Janeiro serem exemplos para a discussão; as palavras de um criativo estudioso do período colonial, ajudam a compreender elementos fundamentais: "A baia da Bahia e a baia da Guanabara são realizações naturais insondáveis. Suas utilização, especialmente na condição de capital, levou e leva em muito conta essa particularidade estratégica." (SILVA, 2012, p.66). Vê-se, portanto, como diria Milton Santos (1997, p.26) em Metamorfoses do espaço habitado "As formas, pois, têm um papel na realização social." No caso de análise aqui proposta, as formas seriam as baias, os portos mais favoráveis, as penínsulas, as ilhas... algumas particularidades na imensidão do mar, havendo diferenciações espaciais há preferencias.

As paradas e os lugares escolhidos para atracar eram fundamentais para proveitosa realização dos deslocamentos. Não fora assim também em outras paragens oceano afora? É o que se percebe em vários enclaves portugueses no grande período das navegações e de ampliação de poder metropolitano, segundo Alencastro (2000, p.17): "Moçambique ganhava ainda relevo por causa de sua situação de porto de escala na rota da Índia. À espera do fim das monções marítimas, as frotas portuguesas invernavam nos portos moçambicanos."

Dependendo a estação do ano, as correntes e marés fortaleciam a ideia de partes do oceano como propicio para chegada e acolhida das embarcações. Nada melhor do que as baias e, para quem sabe navegar, porto é preciso. A escolha em parar em determinado ponto e não em outro, também envolvia os afazeres das frotas no desembarque e na capacidade de oferecer reconstituição necessária de materialidades para continuar viagem. Mas, sem dúvida, a qualidade de destaque de algum porto estava 
nas capacidades que oferecia, principalmente, facilitar chegadas e partidas: “[...] pouco após o meio-dia, o vento soprou do sul e nos colocou em situação de passar entre a ponta setentrional da Ilha de Santa Catarina e a da ilha vizinha do Arvoredo." (ANSON, 1996, p.61), assim descreveu um navegador inglês quando em 1740 lançou âncora nas imediações da ilha.

Para ilustrar a atração de uma boa baia para condutores de embarcações naquele regime de centralidade da navegação, se acreditarmos na observação feita por esse mesmo viajante inglês, reforça a aprazia do tranqüilo ponto de parada, "[...] no estado presente do Brasil e da Ilha de Santa Catarina", diz Anson sobre a necessidade de deixar seu relato sobre a passagem em 1740 para os futuros navegantes, "esta ilha vem a ser de maneira geral, o melhor lugar de refrescamento para nossos armadores, que se querem render ao mar do sul." (ANSON, 1996, p.69). Independente da vontade ou indiferença política, a ilha parecia atrativa a viajantes: o mar era o caminho de então e a porção de terra, o abastecer.

Do ponto de vista dos deslocamentos marítimos (o mar, como a principal das "vias" de deslocamentos), naquele eixo movimentado, era boa "beira de terra" àquela ilha e sua interface de terra firme, continente. Fronteiriça por duas baías, a norte e a sul. Entre elas, ao meio, uma península da ilha com maior proximidade ao continente. Porto estratégico aos olhos de estrategistas, tais como do Conselho Ultramarino - ao fim e ao cabo - de Portugal. Ter ali uma governança não foi uma escolha ao acaso, mas isso só viria acontecer na metade do terceiro século da colonização portuguesa.

Quem ler a tese ( $O$ enigma da capital) do pesquisador Daniel Afonso da Silva (2012), irá perceber como Salvador e Rio de Janeiro também foram influenciados pelas condições geográficas para sediarem a capital em seus respectivos tempos. Os fatores locacionais influenciam as decisões das escolhas políticas. Em tempos de navegação, quem tem as melhores baías com os melhores portos, sai na frente na atração de viajantes precisando abastecer. O suporte da ilha de Santa Catarina parece ter sido fundamental para aqueles tempos de grandes deslocamentos pelo mar.

Queiramos ou não, mesmo com muitas rupturas e mudanças, e quase desaparecimento da força ${ }^{39}$ ou passagem desse circuito que a ajudara eleger como sede (na verdade, desaparecimento do seu porto no século XX), até hoje, ali se encontra a

39 "O desenvolvimento bastante lento do mercado local, embora crescessem as atividades urbanas administrativas e de serviços, fez com que o porto de Florianópolis diminuísse sua importância até perder por completo seu papel de relevância econômica, nos meados do primeiro quartel do século XX." (LIMA, 2002, p.80) 
"capital dos catarinenses", que parece ter demorado a se tornar uma capital de fato; pelo menos, simbolicamente. Então, diferente e inverso do dito pelo poeta contemporâneo: "O passado é uma roupa que" ainda nos serve. ${ }^{40}$ Não porque estaria cristalizado na natureza, não se trata de uma interpretação que naturalize a sede da capital para toda eternidade, mas que entenda sua localização como uma escolha na lógica de uma época. A possibilidade de usos para navegação dos espaços insulares colocou a ilha na rota; atribuições, como mais a frente discuto com relatos de viajantes.

\section{Capilariza, Capital. Não capitaliza a Capital? A ponte para a rugosidade vencer ou o uso da ponte (prótese) para capital acontecer}

Uma rugosidade, já o chamei, mas o é também pelas construções feitas. E algumas das construções ali foram edificadas, por ter sido lugar escolhido como sede da Capitania (como veremos). Rugosidades nela agregadas, ou dos usos dos lugares escolhidos, pois mesmo que sejam constantemente reconstruídos, a própria eleição ou atribuição dada para algum lugar, pode ser uma ruga. Trapiches, edifícios, estabelecimentos, prédios, usos regulares de lugares e como se espera de toda ruga para ela ser, resistiu: os bens materiais construídos a ajudaram a permanecer sendo capital de direito: uma herança de origem colonial portuguesa. Ter dentro de si, ou acolher nela edificações públicas, parecem ter ajudado a mantê-la centro político. Mostra Marlon Salomon (2002, p.228) de certa tentativa de transferir a capital, tirando a sede administrativa dessa localização, vista por alguns como problema. Como foi em 1853:

Coelho lembra que esta "inconveniência" em ali continuar a sede da província, já havia sido objeto de discussão um século atrás, quando se tentou muda-la para algum sítio em terra firme, o qual acabou não ocorrendo muito mais por "capricho" do que por "conveniência pública", por já haver na vila casa de residência de governador, igreja e armazéns reais [...]. (SALOMON, p.228).

Para não se dar importância das construções na ilha edificadas, na década de 50 do século XIX se dizia das mesmas como acanhadas e simplórias (ou insignificantes). Na opinião de alguns, não deveria ser por elas, construções, que a capital continuaria na ilha. (SALOMON, 2002). Mas, acho, essas construções que ajudam na força do lugar.

Por outro lado, alguém poderá fazer um sincero contra-argumento a essa ideia da localização da capital de Santa Catarina como uma ruga, ao também chamar de rugosidade justamente a sua não centralidade. A, talvez, também longa duração em não

\footnotetext{
${ }^{40}$ Licença poética. Trecho da letra Velha roupa colorida. Provavelmente, difícil de convencer algum estudioso de história que "O passado é uma roupa que não nos serve mais", afinal, em Como nossos pais a questão parece reforçar o inverso: "Ainda somos os mesmos e vivemos como nossos pais...".
} 
ter sido sempre, uma capital a polarizar. A não continuidade poderia ser também uma ruga a competir, com a ruga de sede do poder? Não é pra tanto, se compararmos com outros casos no Brasil, como Minas Gerais, quando constrói a primeira capital na República, Belo Horizonte, desencadeando “[...] um processo de desapropriação da população então residente se inicia, a fim de abrir espaços a nova metrópole que surgia de forma apressada." (COSTA, SCHWARCZ, 2000, p.42). Em lei de dezembro de 1893, promulga-se como quatro anos o tempo de construção da nova capital para os mineiros. Em dezembro de 1897 a inauguração da mesma - do araial Belo Horizonte, em capital - "Para celebrar a data, ao anoitecer, como que por um desses encantos modernos, a cidade ficou, de repente, toda iluminada para suas centenas de lâmpadas elétricas que pontilhavam a cidade.” (COSTA, SCHWARCZ, 2000, p.43).

Literalmente, tirou-se a capital de origem colonial portuguesa; a chamada de histórica Vila Rica (atual Ouro Preto) não deixa de ser uma ruga que passou quase completamente todo o século XIX, mas deixou de ser capital de Minas Gerais para a cidade planejada sê-la. Como informam as autoras de uma obra sobre o período, Belo Horizonte vislumbrava um desejo de modernidade, de conquista de tempo por vir, “[...] afinal era a primeira [capital de Estado] cidade republicana planejada que ganhava vida e mostrava que o futuro estava por aí, bem à nossa frente." (COSTA, SCHWARCZ, 2000, p.43). Não coube na busca daqueles tempos modernos, manter na Vila Rica de então, a metrópole que sonhava-se chegar. Goiás também, no século XX, sairá sua capital da época de Província, de uma vila da época da colonização portuguesa para uma nova capital construída; como diz Lucia Lippi Oliveira (2008, p.15):

A construção da nova capital do estado de Goiás, a cidade de Goiânia, inaugurada em 1941, foi um importante marco na política de conquista do interior. Goiânia, assim como a cidade de Volta Redonda (acoplada à siderurgia), fez parte da política de ocupação de novos territórios, da montagem de comunicações entre espaços anteriormente isolados. (OLIVEIRA, 2008 p.15)

Esse não é caso catarinense, em que o Estado não operou transferência física da sede de governo, acomodando-se na escolha feita pela lógica metropolitana portuguesa. Em um País, em que a última capital antes da construção de Brasília, foi sede menos de 200 anos e, em um histórico de 460 anos teve três capitais, todas àquelas que permaneceram capitais de Províncias e Estados podem ser consideradas rugas. Isso para mim não diminui o argumento, por que cada rugosidade é um particular e tenderá a ter múltiplas e mútuas influências com o estado que tem nela a sede administrativa. 
O que teria influenciado permanecer na ilha são muitos e variados fatores, possivelmente tendo alternado ao longo do tempo as vantagens e críticas de ali continuar; não é a proposta dessa pesquisa entender tal questão; a tangenciarei. O fato é que no começo do séc. XX "Apesar das pressões para remover a capital do estado para o interior, a elite não só conseguiu mantê-la em Florianópolis, como também conseguiu canalizar recursos públicos para a remodelação da capital.” (PEDRO, 1997 p.312).

Uma pesquisa mais detalhada em dados e fontes documentais poderá averiguar a hipótese de como, talvez, sua timidez como a capital vai aumentando com a decadência da importância do circuito marítimo. A sua não completa capacidade de receber novos meios de transportes, sem diversificá-los, portanto: “[...] decaiu somente a partir do declínio do uso da vela nas embarcações que se dirigiam para o Rio da Prata e mesmo às frequentes viagens científicas ou simplesmente exploratórias de circunavegação do globo, na segunda metade do século dezenove.” (CORRÊA, 2007, p.68)

Com a progressiva diminuição do uso de embarcações e mesmo a extinção de seu porto, na Ilha não se substitui outros meios de transportes, não sendo servida de vários outros nodais para comunicação, mas caracterizando quase que apenas pelo rodoviário e o de pouquíssimo uso social no início do século XX, o aéreo (comercial): “O transporte rodoviário começava. A aviação civil também. No final dos anos 1920, a Ilha servia como escala técnica para os vôos de empresas europeias que ligavam Buenos Aires ao Rio de Janeiro à Europa.” (LIMA, 2002, p.102). A decadência do porto não significou ampliação de variedades de outras maneiras de locomoção; é como se a ilha fosse se isolando, pois perde o sentido de centralidade como era forte no regime de navegação.

O que a fez capital "originalmente", não foram apenas suas boas baías e portos (de uma territorialidade marítima como veremos), e sim, o poder (da territorialidade) militar. Embora tenha ficado a rugosidade sede administrativa, que talvez, se poderia pensar como simbólico originado nos fortes militares, hoje em ruínas, do porto, pode-se dizer que muito pouca (ou até nenhuma) rugosidade restou. A existência do porto não garantia a ela uma capilaridade com os interiores do território de seu estado, mesmo quando portuária é representada como isolada de outras demais partes de Santa Catarina. E, parece também ter durado muito tempo, como a melhor possibilidade de chegar até ela, apenas, pelo mar: “[...] o declínio do porto de Florianópolis", afirma a urbanista Débora da Rosa R. Lima (2002, p.80) “ocorreu porque seu contato com o interior da província nunca fora facilitado, e nunca houve uma estrada de ferro que 
ligasse ao interior para trocar mercadorias, não estando ele diretamente ligado ao escoamento da produção." Não implementar diversidade de meios de chegar até a Ilha dificultava o acesso e os vínculos do interior com sua capital (ela passa a ser a isolada):

De outro, a sua localização geográfica é um problema. A partir do momento em que estabelecer ligações se torna propício ao aumento do comércio, da agricultura e ao crescimento da população, através da integração dos diversos pontos que compõem a província, percebe-se que a cidade situada numa ilha termina por se isolar, na medida em que as ligações com o continente se tornam difíceis. (SALOMON, 2002, p.227).

A ampliação de deslocamento por meio de caminhos, estradas, transportes por terras, as futuras rodovias, não são naturalmente compatíveis com a Ilha que possui duas baias como área de distanciamento ou, separação, do continente. Talvez, a entrada do circuito automotor para deslocamentos tenha diminuindo e até estranhando ali na Ilha existir a capital. Afinal, mesmo quando ligada ao continente por ponte, haveria de se ter estradas na própria interioridade da Ilha. Coisas que não se constrói da noite para o dia.

Momentos contraditórios de uma capital: assoreamento do canal do porto e baixo escoamento de mercadorias, progressivamente até o limite da não operacionalidade do mesmo, assim como, antes disso, a inauguração da ponte Hercílio Luz. $^{41}$ Não há consenso na literatura de que a ponte tenha significado diretamente uma conexão maior da capital com o território catarinense. Até por que a capital não acompanha a incorporação de novos meios de transporte, fora sua ponte, como mencionado. Para alguns, materialmente, passou haver uma verdadeira ligação, tornando o deslocamento independente dos fatores climáticos e das intempéries. A ponte supera as baias como marcações do limite entre ilha e continente e, realmente, em termos financeiros significou um investimento econômico por parte do Estado, bastante relevante, assumindo a posição da preferência pela Ilha como a capital:

[...] a construção da primeira ligação ilha-continente, cujo custo total excedeu 10 vezes a receitas orçamentarias do Estado; mas que significou o grande enfrentamento da cidade com seus limites físicos de crescimento, o que, de certa forma, garantiu a permanência da cidade como capital do Estado. (LIMA, 2002, p.99)

\footnotetext{
${ }^{41}$ Para Tamara Benakouche (1996, p.42): “[...] a demanda local dirigia-se mais para a melhoria dos serviços marítimos, que funcionavam de forma bastante precária; por outro, havia um movimento pressionando pela transferência da Capital para a cidade de Lages, no Planalto Catarinense. Seus partidários viam a construção da Ponte como uma obra faraônica." O projeto de construção da ponte envolveu discordâncias. Para quem dependia da navegação, a prioridade deveria estar na melhoria dessa forma de deslocamento. Para quem pensava no automóvel como nova forma de deslocamento, as estradas eram prioridade. O projeto da ponte é da primeira década do século XX, mas inaugurada no ano de 1926.
} 
Entretanto, mesmo a ponte projetada ${ }^{42}$ para também sustentar ferrovia, o projeto ficou apenas circunscrito em uso veicular, sem ter existido um caminho de ferro que chegasse até ela, reforçando a ideia de uma integração bastante parcial. Pelas indicações da literatura sobre a temática, o maior impacto da construção da ponte foi uma progressiva urbanização da capital, sem corresponder maior relação com o interior:

A ligação ferroviária com o restante do território, que iria determinar o fim do isolamento da capital com outras partes do Estado, nunca foi efetiva; porém a intenção de superar e enfrentar os limites de tal isolamento, representados claramente com a construção da ponte, irão determinar o direcionamento da cidade daí para frente. (LIMA, 2002, p.100).

Talvez, possa ser legitimo argumentar, como foi o benefício ${ }^{43}$ da ponte mais bem usado em favor de um tipo de crescimento econômico para a própria Ilha do que para as demais partes de Santa Catarina. Questão ainda a ser melhor pesquisada, não apenas elencando quais critérios de análise para pensar as melhorias com a ponte ou não, mas sim problematizando: a existência da ponte passa a ser argumento utilizado para não mais justificar a ideia de estar a Ilha - isolada - e sem ligação por terra. Gostaria de questionar: teria a capital, com a ponte, se integrado ao território catarinense, assim como as demais regiões teriam visto a partir dela - a ponte definitivamente conectados à capital? Há quem responda negativo a questão: "Mesmo com a primeira ligação com o continente [ponte], em 1926, a cidade/ilha não conseguiu impor-se ao conjunto do Estado." (KUNTZ, 2013, p.152)

Parece legitimo a hipótese de saída de pesquisa, questionar: quando se inaugura uma ponte ligando Ilha ao continente, tempo social em que a forma reflete a nova função (e, portanto, um relevante sintoma das estradas e não mais da navegação), talvez, ali passa-se a desconfiar cada vez mais da Ilha como a capital. A presente pesquisa não tem necessariamente respostas para essa questão, o fazer dela - interrogar - já é um desafio intelectual a ser legitimado em debates acadêmicos e esferas de discussões críticas públicas/abertas. Antes de por um fim, quer-se debater o problema.

\footnotetext{
42 “[...] é construída a primeira ligação ilha-continente, que também foi projetada e executada para suportar uma linha ferroviária." (LIMA, 2002, p.100).

${ }^{43}$ A maior parte do balneário de praias e baias do Continente fronteiriço à Ilha passa à jurisdição da administração do Munícipio da Capital (deixa de ser de São José/SC). Praias passaram a ser badalas por uma elite da capital, havendo mais rapidamente infra-estrutura, segundo argumenta Débora da Rosa R. Lima (2002, p.117): "Em 1944, o Interventor Federal em Santa Catarina, Nereu de Oliveira Ramos (da oligarquia Ramos), assinou o decreto $n^{\circ} 951$ que agregou o Estreito à capital, desmembrando-o de São José. É interessante observar que o município da Capital, pelo decreto, tenha passado a ter uma parte continental que a estendeu da Ponta do Leal, ao norte, até à praia do Abraão, ao sul, tomando para a capital, desta forma, justamente as praias onde a elite florianopolitana veraneava."
} 
A construção da Ponte Hercílio Luz impôs-se, já nos finais dos anos [19]10, como uma condição necessária à manutenção da Florianópolis como capital de Santa Catarina. Até então, todo o transporte de pessoas, animais e mercadorias, entre Continente e a Ilha, era feito através de barcos. A travessia nem sempre se realizava de forma tranquila e regular, dependendo das condições climáticas e, mais especialmente, do regime de ventos e marés. Diante das frequentes interrupções nos serviços de barcos, e dos problemas que isto trazia, surgiu, no Planalto Catarinense, um movimento reivindicando a transferência da capital para essa região, no caso, para a cidade de Lages, então o seu principal centro urbano. (BENAKOUCHE, 1996, p.36-37).

Se o discurso de defesa do projeto e da construção da ponte não conseguiu necessariamente executar a busca de unidade regional de Santa Catarina e, de alcançar uma coesão territorial, ao menos parece que a obra imponente deu maior credibilidade à capital continuar tendo a mesma sede. ${ }^{44}$ Talvez, a partir da presença da ponte, isso tenha sido usado para calar as oposições à Ilha como a sede do poder. Segundo o governador idealizador da obra parece ter afirmado, em setembro de 1920, a ideia da capital como cérebro - na metáfora corporificada ${ }^{45}$ - estava desgrudado das demais partes do corpo. A ponte seria uma espécie de pescoço, pois “[...] afirmará praticamente a união e a integração do nosso território, e das nossas aspirações, evitando que a cabeça mutilada continue fora do corpo.” (HERCÍLIO LUZ, Apud, BENAKOUCHE, 1996, p.43).

Entendo que permaneceu ambiguamente como uma capital "centro" e periferia, passando por tensões, deslegitimidades (e relegitimidades), coerção, contestação e mesmo até certo grau relativo de capilaridade (às vezes de pouca integração) e baixa afinidade com "partes" do território que governara. Uma reportagem de revista de circulação nacional chegou a mencionar o aspecto de outros municípios desejarem atrair para si, a sede administrativa catarinense e isso quando da construção de outras pontes, na reportagem dos idos de 1972, chancelava como foi a partir da primeira ponte que se calou as tentativas dali tirar à capital e, principalmente, a indústria imobiliária com altos índices de consumo de cimento:

Ligada permanentemente ao continente, sem depender mais dos caprichos do vento, Florianópolis cresceu e calou as antigas contestações de Lages e Blumenau, insatisfeitas com a sua condição de capital. As pequenas indústrias

\footnotetext{
44“"A posição de Florianópolis como centro político-administrativo do Estado se afirma, a partir do momento em que, não mais isolada do restante do território, vai aos poucos se integrando à sua dinâmica e exercendo seu papel com maior credibilidade." (LIMA, 2002, p.101). (destaques meus)

${ }^{45}$ Arquitetar um espaço visando sentido de dar ordem ao edifício é uma maneira de "capitalizar um território" segundo Michel Foucault (2008, p.23) nos diz, em Segurança, Território e População. Adaptar novos desenhos do suporte físico, para promover a circulação foi pensado como uma boa forma do espaço resultaria (ou condicionariam) bons exercícios nele. No caso de Nantes, na França, diz Foucault: "Vê-se que o problema era a circulação, ou seja, que para a cidade ser um agente perfeito de circulação, deveria ter a forma de um coração que garante a circulação do sangue." (FOUCAULT, 2008, p.23).
} 
foram brotando nas imediações, e a construção civil consome hoje mais cimento que as três outras principais cidades do Estado (Joinville, Blumenau e Lages) reunidas. (REVISTA VEJA, n²25, 27 Dezembro 1972, p.53).

Teria a ponte sido usada para deslegitimar as vozes solicitantes de mudanças da capital. Isso de alguma maneira refletiu no regionalismo que tendeu a avaliar com alguma desconfiança a capital continuar dentro da Ilha, mas (por causa da ponte) não mais, apenas, ilhada... O ascender de uma elite econômica na área de pecuária do planalto também influenciou nesses questionamentos da administração do Estado continuar na Ilha:

Grande parte da força da elite local [de Florianópolis] vinha do controle que as famílias possuíam sobre os cargos públicos em nível estadual e federal. Porém, já a partir da década de [19]10, esses grupos perderam em parte sua influência política, com a paulatina ascensão de políticos oriundos da região de pecuária do planalto catarinense. (PEDRO, 1997, p.312).

Além de ascensão de grupos no interior a concorrer com os estabelecidos na capital, poderia se questionar: quais elites de outras partes e regiões de Santa Catarina buscaram ocupar o lugar de uma tradicional elite ilhéu governante do território catarinense? Não seria o caso de apontar limites para certa rugosidade, relativa, quando "resbalava" ou não conseguia ter centralidade ou polarização? Ou seja, não é porque o poder tinha como sede administrativa na capital a Ilha, que fora dali sempre a emanar as lideranças política; às vezes poderiam se instalar, mas eram originados de outra região. Uma maior afinidade da Ilha, a partir da inauguração da ponte com o território de Santa Catarina não significou, necessariamente, liderança na pujança econômica. Do ponto de vista do crescimento capitalista, por exemplo, outras regiões também começaram a destacar-se; talvez isso ajude a compreender a demora em realizar o projeto do reconhecimento social da sede administrativa do governo de Santa Catarina.

Tabela 1 Movimentação dos Portos de Santa Catarina para ano de 1969, segundo Ferreira (1971)

\begin{tabular}{|llr|}
\hline $\left.1^{\circ}\right)$ & Imbituba & 900.000 toneladas \\
\hline $\left.2^{\circ}\right)$ & Itajaí & 494.043 toneladas \\
\hline $\left.3^{\circ}\right)$ & São Francisco do Sul & 125.000 toneladas \\
\hline $\left.4^{\circ}\right)$ & Florianópolis & 57.519 toneladas \\
\hline $\left.5^{\circ}\right)$ & Laguna & 1.628 toneladas \\
\hline
\end{tabular}

É possível observar posição de menor destaque do porto da Capital. Ref.: FERREIRA, 1971, p.118

Na comparação de movimentação portuária da capital com os demais portos de Santa Catarina para o ano de 1969 (Tabela 1), segundo dados elencados por Ferreira (1971, p.118), é perceptível um desnível bastante grande de Florianópolis, provavelmente dentro da conjuntura de decadência de seu porto, finalizando atividades. 
A capital nem sempre capitalizava, ao menos não na velocidade/pujança de crescimento como passa-se a ver em outras regiões, líderes em termos de produção econômica, mas ela resiste como liderança de sede de governança:

[...] embora Florianópolis não estivesse no centro das transformações por que passava o Estado de Santa Catarina nas primeiras décadas do século XX - e que finalmente o integravam ao contexto econômico nacional -, resistiu agora como Capital do Estado, apesar das pressões contrárias, e dos movimentos à mudança da sede do governo catarinense para o interior do Estado. (LIMA, 2002, p.106107).

Aconteceu, para estudiosos da história catarinense, beneficiamento da capital por reter, pelos tributos, parte do crescimento econômico ocorrido em outras regiões de Santa Catarina. Nas primeiras décadas do século passado: "Embora, no início do século [XX], a capital estivesse em pleno declínio econômico, o mesmo não ocorrerá com as demais áreas do estado de Santa Catarina." (PEDRO, 1997, p.312). Como afirmou Joana Mª Pedro (1997, p.313): “A indústria, o comércio e a agricultura, principalmente no vale do Itajaí, estavam em plena expansão. Florianópolis acabou então sendo beneficiada como capital do estado pelo crescimento econômico das demais áreas."

Feitos tais ponderações e questionamentos com breve discussão ensaística para provocar a entrada no panorama histórico da base territorial de Santa Catarina, impossível não falar da ilha que nomeou todo o Estado. Impossível não lembrar como, embora hoje pareça irrelevante, houveram manifestações em diferentes épocas ao longo do tempo tentando tirar dali a capital. Por isso, a vejo como uma ruga, mais pela época que lhe deu esse status e pela resistência na permanência, ultrapassando outros tempos sociais em que a navegação, destaque do litoral, ter fortalezas, sede de governança militar ou um porto já não causava mais alguma relevância. ${ }^{46}$ Estou discutindo alguns contextos na relação de como a sede da administração do Estado resistiu na Ilha.

Uma Capital Vacilante, assim a chama pesquisa mapeadora de alguns discursos considerados como limitadores ou reivindicadores de ali não continuar sendo uma capital aonde era e, é. A constatação como da falta de riqueza, pouco urbana, não ter pujança econômica e sim muita pobreza: "Dentro dos debates para a transferência da

\footnotetext{
46 “Por não possuir uma ligação ferroviária com o interior do Estado ou com o restante do país, o porto de Florianópolis havia-se transformado, basicamente, em um porto de serviços [...]." (LIMA, 2002, p.107). A passagem a seguir de Kuntz (2013) faz uma explicação funcionalista, não histórica, com interpretação na qual não concordo, para ele: "O comércio, e depois o porto que se instalou na ilha, se não deram a ela logo de início o status oficial de Capital, mas fizeram da cidade um ponto importante, que logo transformaria o povoado e sua popularidade em oficialidade, nascendo assim, a Capital do Estado." (KUNTZ, 2013, p.43). Alguma centralidade de governo na Ilha inicia com a capitania subalterna de 1738.
} 
sede administrativa, Florianópolis teve esse posto questionado primeiro por ser uma cidade cuja falta de dinamismo socioeconômico impedia de ostentar o título de Capital catarinense." (KUNTZ, 2013, p.29). No processo de progressiva industrialização de algumas antigas colônias e passagens delas de áreas rurais para urbanizadas, em termos econômicos algumas tenderam a ultrapassar a capital em capacidade de acumulação de riquezas. Como se então as demais regiões ao contribuírem mais, estivessem a sustentála. Havendo uma elite a coordenar destinos dos recursos públicos do Estado, isso pode ter reforçado imagem de privilégio a incomodar a sede na Ilha; pela drenagem do cofre:

A área central de Florianópolis, neste início de século [XX], passou por inúmeras reformas e melhoramentos. Convém destacar que na época a cidade não possuía nenhuma atividade que permitisse qualquer nova forma de acumulação: o porto continuava em declínio; o comércio, em constante decadência, restringia-se ao consumo local; a produção industrial era diminuta; a produção agrícola da ilha não abastecia suficientemente a população local. Vinham de outras localidades do estado os produtos necessários. Portanto, as reformas urbanas, realizadas em Florianópolis no início do século XX, dependeram, principalmente, da força de sua elite política. (PEDRO, 1997, p.312). (destaques meus)

Àquelas cidades fundadas originalmente como núcleos coloniais de imigrantes europeus, não se viram necessariamente refletidas na pobre e singela capital, passada a ser remodelada, e as demais partes do estado, talvez, a concebiam como uma sede distante. Um segundo fator apontado como certo desconforto da sede administrativa estava mais uma vez, assim como se dizia no século XIX, na sua localização 47 “[...] o fato de a cidade situar-se em uma ilha, o que a deixaria com poucas condições de crescer e ter os aparatos que uma Capital necessita." (KUNTZ, 2013, p.29).

No começo dos anos da década de 1990 e embalados pela elaboração da constituinte estadual no ano anterior, o Parlamento catarinense chegou a colocar em votação a proposta de um projeto apresentado na Assembleia Legislativa de Santa Catarina/ALESC a respeito da ideia de transferir a capital para o centro geográfico do território catarinense, ao meio de todo o estado, município de Curitibanos. A maioria dos deputados votou contrária a matéria, de maneira que não se chegou a realizar consulta em plebiscito, mas essa proposta contestava tanto um maior equilíbrio na distribuição dos impostos como também a distância da capital. Estando Florianópolis longe dos demais municípios, acusando-a de abandono: “A ideia para levar a Capital

\footnotetext{
${ }^{47}$ Se até o século XVIII é por ser uma ilha, valorosa no circuito da navegação, que a gera alguma centralidade, ao final do século seguinte, o discurso parece ter se invertido, passando ser problema.
} 
para outro ponto de Santa Catarina ganhou fôlego nas discussões, como meio para uma melhor articulação entre os municípios e sua Capital.” (KUNTZ, 2013, p.119).

As posições contraditórias atribuídas a capital ao longo da história catarinense dizem um pouco, se não, muito, das relações com as demais partes, do pertencimento ao do território do estado que ela é dado a governar. Sem desejar promover etnocentrismos e rusgas, é necessário refletir como a história da constituição da capital é também, em parte, a geohistória do território de Santa Catarina. Aliás, até 1820, quando então o planalto era paulista (e passa ser de ou em) Santa Catarina, a área de influencia da atuação da capitania catarinense reduzia-se estritamente e, apenas, uma não muito $\operatorname{larga}^{48}$ área do litoral: “[...] a Capitania de Santa Catarina compreendia uma estreita faixa litorânea, com suas ilhas, entre elas aquela onde estava localizada a administração da Capitania, a vila de Nossa Senhora do Desterro." (ROSSATO, 2007, p.21). Florianópolis é o nome republicano que a capital passou a ter ao final do século XIX (em substituto à Desterro). ${ }^{49}$

A pouca integração não ocorrera apenas da Ilha com o continente e seu território a ser governado, mas dentro - interno - da própria Ilha. Ao menos no século XVIII as freguesias $^{50}$ às vezes pareciam "tão ilhadas" (o que não significa isoladas), distantes e independentes do "núcleo" urbano central primário - o mais próximo do continente e da ilha - o centro político agregador (o espaço pioneiramente citadino). Parecia distante das próprias outras freguesias localizadas na Ilha. As históricas relações contraditórias de outras regiões e partes do território de Santa Catarina, diz de suas relações (conflitos, desconfianças e de relativa lentidão de agregação) com sua capital; inclusive, com tentativas de desbancá-la.

\footnotetext{
${ }^{48}$ Em termos temporais, a anexação de Lages (em 1820) a Santa Catarina durou aproximadamente 2 anos do período colonial, pois em 1822 o Brasil é independente. Mas o importante é chamar atenção para o fato de que a incorporação do planalto definitivamente marca muito o traçado do que viria a ser o território dessa Província. Como lembra Adelson A. Brüggemann (2008, p.47), a partir da construção de uma estrada ligando (as capitanias de São Paulo e Santa Catarina) de Desterro à Lages, pago pelo erário de Santa Catarina fundamentará a ampliação da capitania para o interior: "Assim, a abertura do caminho para a vila de Lages deve ser destacada como contribuição fundamental para o delineamento dos limites da capitania de Santa Catarina.” (BRÜGGEMANN, 2008, p.47)

49 Na homenagem que o mesmo governador idealizador da ponte (obra que leva seu nome) faz a Floriano Peixoto, pela vitória do presidente na Revolução Federalista e que na Ilha foi palco de resistências e alguns lugares do interior de Santa Catarina, maior apoio ao Marechal de Ferro. Em termos simbólicos, a "toponímia" da capital é resultando de uma batalha e imposta pelo governador a uma cidade vencida, o que mais uma vez reforça a lógica de domínio do espaço bastante autoritária, mesmo simbolicamente.
}

50 Segundo Luis Augusto da Silva $(2008$, p.87) "No interior da própria Ilha de Santa Catarina, as pequenas freguesias formavam também espécies de 'ilhas' isoladas entre si [...].” 
Talvez, tenha sido mais uma cicatriz (ou ruga) cartográfica do que uma imposição; algo como uma legitimidade coercitiva. Não quero explicar, a seguir, como se em um processo de ordem natural desse espaço tornou-se sedentário do poder. Antes de dar uma resposta final e conclusiva, é preciso colocar em discussão, trazer ao debate e propor uma reflexão menos apaixonada do que deveria ter sido e sim, elevar as possibilidades de fazer também as histórias dos espaços e suas relações com suas gentes e como um fator, embora não como um agente pronto, acabado ou determinante. Se os espaços influem, possibilitam, predispõem, autorizam, permitem, dão suporte, enfim, estruturam, não governam. Ou melhor, não influencia no governar tudo e sempre do mesmo jeito, como veremos. As discordâncias também (con)formam territórios e as ações das agências humanas é quem, por fim, dão sentidos aos espaços e talvez até, os permitam serem determinantes, quando os são (alguém dirá, questionando legitimamente: "se é que são" determinantes). Proponho a seguir, compreender o contexto que a inventou - a ilha - como uma governança e esse aspecto está diretamente relacionado à emergência do território de Santa Catarina; de duas territorialidades iniciais, a marítima e, principalmente, a militar.

Territorialidade do navegar, antes da territorialidade militar. Ou, "Uma baía do Continente, larga e cômoda, que os franceses chamam de 'Bom-port'." - Anson

Não havia o Brasil antes de 1822, e nem imediatamente após a Independência. Não quanto uma nação pronta em si mesma, nem uma comunidade e unidade (colonial) integrada, monolítica. "Se, na conjuntura da descolonização, falava-se numa unidade territorial brasileira, é preciso, no entanto, considerar que ela era mais aparente que o real. Ela ainda estava em construção." (PICCOLO, 2005, p.577). Havia um "Brasil só", mas aparecia nos desenhos e na governamentabilidade do Conselho Ultramarino. "A unidade do domínio Brasil existia somente no mapa.” (SILVA, 2012, p.15). Nem mesmo uma América portuguesa havia, não: "Terra que não era toda uma só." (ALENCASTRO, 2000, p.20). Segundo Luiz F. Alencastro (2000), o rotineiro contato e

\footnotetext{
${ }^{51}$ Como afirma Antonio Carlos R. Moraes: "De uma figura mítica do imaginário medieval celta, reproduzida e difundida pela cartografia seiscentista, o Brasil passava a existir como uma entidade geopolítica da administração colonial portuguesa, dotada de uma unidade dada pelo olhar do Conselho Ultramarino ao governar estas terras."'(MORAES, 2010, p.60) (destaques feitos por mim). "Nesse sentido, poder-se-ia argumentar que não havia uma consciência política interna da unidade brasileira, porém tal consciência existia na visão metropolitana, a qual inclusive buscou apresenta-la como uma unidade natural [...].”(MORAES, 2006, pp.50-51). Segundo afirma Demétrio Magnoli (1997, p.126) "A unidade territorial passou, regra geral, a ser encarada como uma herança [...] de um suposto legado colonial."
} 
existência de um verdadeiro fluxo entre áreas dispersas tornava o Atlântico mais uma via de encontro e superação de distanciamentos do que, apenas, separação entre os enclaves fundados/dominados por portugueses nos dois lados do oceano. ${ }^{52}$ Podendo, em determinado período da época colonial, ter ocorrido maior identificação e proximidade (de trocas) entre áreas distantes do império português do que, entre as "mais próximas".

A menos quando interessava defender-se e resguardar a posse, podia se aglutinar ajuda; influenciados por noção de distâncias e de proximidades, completamente próprias aos respectivos momentos. A abertura de alguns caminhos e melhoria de estradas também visavam alcançar apoio entre diferentes partes, como aparece ter ocorrido com maior força, a partir do século XVIII:

Desde o início do século XVIII, quando os franceses e espanhóis ameaçavam os domínios portugueses, para fortalecer a resistência a essas invasões estrangeiras, foi criada a regra de defesa mútua entre as capitanias. Isso implicava que qualquer unidade administrativa atacada por estrangeiros receberia ajuda das demais capitanias, desde que estivessem integradas por caminhos que ligassem uma à outra. Para isso, foi necessário estabelecer comunicações terrestres e/ou fluviais entre elas. (BRÜGGEMANN, 2008, p.132).

Os regimes de ventos e navegabilidade influenciaram diretamente, durante certo período colonial, na composição territorial e afinidade das colônias portuguesas. Exemplo, ainda durante o período da união das Coroas Ibéricas (entre 1580-1640), estabeleceu-se “[...] a criação do Estado do Grão-Pará e Maranhão decidida em 1621, com um governo separado do Estado do Brasil, responde perfeitamente ao esquadro da geografia comercial da época na navegação a vela.” (ALENCASTRO, 2000, p.20).

Há consenso bastante generalizado no debate que constata não ter havido, na gestão de territórios portugueses além mar, como a América portuguesa, uma unidade contigua tão significativa que desembocaria automaticamente - de territórios coloniais em território nacional, independente. Unidades às vezes muito mais dispersas e autônomas, algumas até mais ligadas ao exterior, do que interligadas entre si. Dependendo o período histórico e o critério das representações cartográficas, percebe-se bastante diferenças de um mapa de época em relação às divisões de jurisdições internas na contemporaneidade. "Nossa história colonial não se confunde com a continuidade do nosso território colonial." (ALENCASTRO, 2000, p.09).

\footnotetext{
52 "Na verdade, os condicionantes atlânticos, africanos - distintos dos vínculos europeus -, só desaparecem do horizonte do país após o término do tráfico negreiro e a ruptura da matriz espacial colonial, na segundo metade do século XIX. Tais condicionantes marcam a originalidade da formação histórica brasileira." (ALENCASTRO, 2000, p.21). (destaques feitos por mim).
} 
Não se trata de uma aparente contradição a eliminar decididamente e completamente a influência ou não, da gestão territorial dos tempos coloniais. De um lado, entender a não reprodutividade automática das divisões e governanças na América portuguesa para os tempos seguintes do Brasil pós-Independência, por outro, não recusar de todo como às práticas coloniais puderam influenciar na constituição do território do País. Essa reflexão reforça a tese de Benedict Anderson (2005, p.83) quando afirma "A configuração original das unidades administrativas americanas foi, até certo ponto, arbitrária e fortuita, assumindo os limites espaciais das diversas conquistas militares." Contudo, existindo mudanças: "Mas, com o decorrer do tempo, acabaram por adquirir uma realidade mais consistente sob a influência de factores geográficos, políticos e econômicos." (ANDERSON, 2005, p.83)

Com isso, quero chamar atenção para o fato da dinâmica temporal ser um veículo de permanências e mudanças: “[...] a noção que se tem da transformação das capitanias em províncias e destas nos estados - continuidade que em certo sentido de fato existiu -, não deve encobrir as rupturas e diferenças entre uma formação e outra." (SILVA, 2008, p.65).

É necessária retrospectiva para acompanhar estabelecimentos das fronteiras e limites internos em cada parte da América portuguesa. A consciência da importância de uma abordagem de Geografia histórica serve muito bem para discutir e compreender o moroso - repleto de tensões - processo da constituição de jurisdições das governanças, das áreas a serem, posteriormente, constituídas do território catarinense:

Deve-se ressaltar que o mapa da capitania de Santa Catarina, não possuía os contornos atuais. Seus limites estavam circunscritos às proximidades da costa marítima. O povoamento por vicentistas, no século XVII, e por portugueses, no século seguinte, ocuparam apenas as planícies litorâneas. Até o início do século XIX, o território correspondente aos municípios de Bom Retiro, Urubici, Lages, Campos Novos, Curitibanos e todo o oeste pertencia à capitania de São Paulo. O interior paranaense também fazia parte dessa capitania [paulista]. (BRÜGGEMANN, 2008, 19).

É impossível projetar no passado colonial, uma mesma cartografia do Brasil atual, sendo até "[...] anacronismo do procedimento que consiste em transpor o espaço nacional contemporâneo aos mapas coloniais para tirar conclusões sobre a Terra de Santa Cruz." (ALENCASTRO, 2000, p.20). Ainda para o mesmo autor, "A continuidade da história colonial não se confunde com a continuidade do território da Colônia." (ALENCASTRO, 2000, p.20). Para Augusto da Silva (2008), deve-se rejeitar narrativas colocando, desde tempos imemoriais, um espaço do que seria Santa Catarina 
sem a percepção das alterações existentes. Essas simplificações inventam no passado uma divisão do espaço no presente, como que buscando as origens de seus mitos fundadores territorialistas. (Destaques na citação a seguir, feitos por mim):

Com base nas reflexões de Antônio Manuel Hespanha sobre as relações entre poder e espaço, assim como de Antonio Carlos Robert Moraes sobre a formação territorial do Brasil Colonial pôde-se problematizar a estrutura político-geográfica do Governo da Ilha de Santa Catarina e rejeitar as representações históricas que projetam num passado remoto as atuais configurações territoriais do Estado Catarinense. (SILVA, 2008, p.16).

Considero pertinente reforçar a interpretação que entende a emergência no período colonial, mais como uma concepção espacializante de Brasil do que, um território brasileiro propriamente dito. Explico-me. Tem-se acordado, naquela literatura interessada em discutir aspectos territoriais do Brasil, não ter existido, no que se convencionou nominar período colonial, tanta articulação homogênea e equilibrada entre diversas partes do Império português na América. ${ }^{53}$ Uma coisa foram os discursos das intenções de integração e da vontade de homogeneizar, outra as efetivas interações: "[...] não tinha fundamento a ideia veiculada de que a nação brasileira tinha sido gestada no passado colonial. Assim, falar em homogeneidade/uniformidade, no pensar o político, não se sustenta." (PICCOLO, 2005, p.577).

Já pelo final do setecentos, por exemplo, a difusão da ideia de emancipação e liberdade promovido por Joaquim da Silva Xavier, Tiradentes, ocorria numa abrangência do que muito mais tarde passaria a ser considerado o centro ${ }^{54}$ do Brasil; onde foram mais fortes o republicanismo e as maiores presenças dos clubes Tiradentes (CARVALHO, 1990, p.67). "Tiradentes era o herói de uma área que, a partir da metade do século XIX, já podia ser considerada o centro político do país - Minas Gerais, Rio de Janeiro e São Paulo, as três capitanias que ele buscou, num primeiro momento, tornar independentes." (CARVALHO, 1990, p.67). Não havia como termos um herói nacional, antes da nação. Embora existam heróis nacionais que construam a nação, portanto, préexistam a ela, a inventam. No Brasil, antes da nação brasileira, poderiam ter havido áreas mais coesas ou conectadas entre si mesmas. $\mathrm{O}$ movimento liderado por Tirantes

\footnotetext{
53 Para Antonio Carlos R. Moraes (2006, p.50): “Tomar as referências geográficas como supostos constitui equívoco similar ao anacronismo histórico, pois se trata também de construções sociais, inventadas no jogo político da sociedade."

${ }^{54}$ José M. de Carvalho (1990, p.67) atribui parte do sucesso dos lideres do movimento, justamente seus contatos, disposição espacial a qual se encontravam e vínculos de proximidade: "Um dos fatores que podem ter levado à vitória de Tiradentes é, sem dúvida, o geográfico.” (CARVALHO, 1990, p.67).
} 
parece indicar, ao menos, certa comunicação e mútuas influencias, mas a ideia do País e das articulações do território do Brasil não se processava da maneira como ocorre hoje.

Tanto assim, logo após a Independência, a busca de evitar com que áreas viesse a fragmentar-se em Estado territorial (nacional) independente é tema candente. Reforçando a ideia de não ter existido tal unidade, mas o inverso (destaques meus):

[...] a manutenção da integridade territorial e, pari passu, de uma perspectiva de expansão das fronteiras colocou-se como sendo a mais emergencial das tarefas das elites políticas do Império. Entretanto, não herdava-se da colônia apenas um território em vias de fragmentação, mas uma sociedade estruturada sobre o trabalho compulsório dos escravos, vastos fundos territoriais em disputa na região do rio da Prata e um Estado por construir sobre as ruínas da antiga condição da colônia. É claro que herdava-se também os acordos comerciais com a Inglaterra, as dividas portuguesas em libras e uma série de instituições erigidas à moda francesa. (FERNANDES DE SOUSA NETO, 2004, p.06).

Havia distâncias, dispersões, imensas áreas e mesmo certa tradição de tentativa de mitos unificadores, como houve a ideia de uma certa Ilha Brasil. Discurso utilizado pelo poder metropolitano tanto para legitimar domínio - ainda mais de ilhas, algo tão ao gosto "das práticas" marítimas portuguesas - quanto visando configurar exclusividade de apropriação de "terra homogênea", sendo uma ilha facilitaria domínio pela metrópole em relação à suas concorrentes. Busca por uma unidade geográfica econômica humana a ser defendida, influenciou na criação de produções cartográficas. Destacando nelas o Rio Amazonas e o Rio da Prata, como se essas macro bacias hidrográficas tivessem uma mesma nascente no interior (CORTESÃO, 1955, p.66).

Pela região correspondente hoje ao bioma Pantanal, proximidade do atual Norte do Estado do Mato Grosso do Sul e, Sul do Estado do Mato Grosso, estaria localizado uma espécie de grande lago, formador do imenso rio ao norte e um outro rio ao sul. Para Jaime Cortesão (1955, p.71), houve interesses na intencionalidade em individualizar um espaço, para criá-lo como um produto português: "a lenda geográfica do grande lago, origem comum dos dois rios que insulavam o Brasil, tão reproduzida no século de Quinhentos, reflete o conhecimento dos vastíssimos pantanais em que o Paraguai, se perde na ocasião das cheias.” (CORTESÃO, 1955, p.71)

O potencial de simultaneidade como "uma mesma área representada" em mapas, chama a atenção de Benedict Anderson (2005), quando ele aponta a capacidade de, a partir dessas cartas, gerar sensação de agregação, dependendo da forma como são representadas. Partilhar imagens de um espaço colocado como sendo comum, mesmo abstratamente nos símbolos cartográficos, tem papel de ajudar na sensação de ser uma 
área comunitária. Alguns mapas podem ter potencial de atuar na constituição imaginada do pertencimento aos espaços representados como coesos. Delimitada, traçada, exposta e inventada em desenho, os mapas contribuem na invenção da nação, principalmente tais como àqueles de corpos únicos, forte símbolo na criação e do gerar pertencimento de simultaneidade. "Seriam esses mapas também uma forma de apropriação simbólica desses territórios.” (BRANDT, 2012, p.36).

Logo nas primeiras décadas do século XVI já apareceram desenhos em cartas de localização, da porção de terra sendo Ilha Brasil. "Na carta de Lôpo Homem de 1519", escreve Jaime Cortesão (1955, p.64) sobre a apropriação do espaço através de demarcações nos mapas, "duas bandeiras portuguesas, colocadas respectivamente ao norte do Amazonas e ao sul do Prata, marcam claramente a intenção de fixar pelo delta amazônico e o estuário platino os limites do Brasil, embora aí não figure o traçado da linha divisória." (CORTERSÃO, 1955, p.64).

Título da Imagem 2: representação da América Portuguesa como unidade insular século XVI

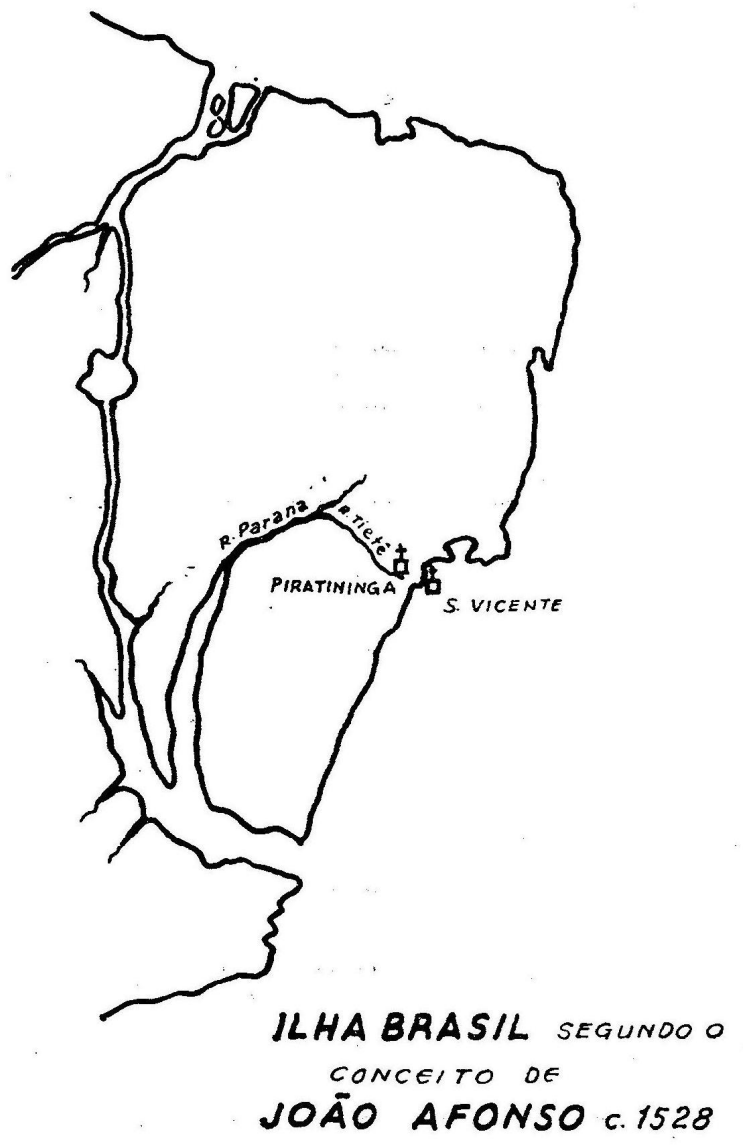

A ESTA CARTA ACRESCENTOU-SE A VILA DE PIRATININGA, FUNDADA EM 1532. PARA

Imagem 2 Exemplo de Representação cartográfica da Ilha Brasil (Ref.: CORTESÃO, 1955, p.121) 
A imagem (n², pág anterior) é um exemplo, para ilustrar a difusão da produção de representações sobre a Ilha Brasil como uma primeira unidade natural de corpo coeso, único, difundido pela cartografia colonial. Ao representar a um Oeste, ao interior, as nascentes dos dois grandes rios conformadores da Ilha Brasil, certamente ampliava muito além do Tratado de Tordesilhas a área a ser dominada pela coroa lusa. Quando da vinda do $1^{\circ}$ donatário da Capitania de São Vicente, os portugueses já difundiam ser um corpo de terra homogêneo e nessa invenção, acabam por serem seguidos pelas cartografias produzidas em outras nações. ${ }^{55}$ "Em resumo: ao terminar a $3^{\text {a }}$ década de Quinhentos, ou seja quando Martim Afonso parte para o Brasil, os portugueses já tinham ideia de uma unidade geográfica humana, a que, deram a forma geométrica da Ilha-Brasil, mito expansionista lusoamericano.” (CORTESÃO, 1955, p.71).

Portanto, pode-se afirmar, através de esforços da criação de representações de união - e apelo à unidade natural - como, embora, delimitado, não havia predestinação geográfica do território do Brasil; por isso, inventavam-se tais coesões de terra. Circunscrito, mas não coeso. A Ilha Brasil, um mito territorial de corpo inventado.

Nas partes do sul da América Ibérica (se o termo não for muito abrangente, se não: na imensa área Platina da América) duas formações sociais são destacadas para compreender a territorialidade do que viria a ser a partir do século XVIII, Santa Catarina. Paul Singer (1968) em sua tese doutoral, explica: "Santa Catarina constitui, no período colonial, zona de transição (do mesmo modo que o Paraná e o Rio Grande do Sul) entre dois focos importantes de colonização e povoamento: São Vicente (e São Paulo) ao norte e o Estuário da Prata ao Sul.” (SINGER, 1968, p.81-82).

Para as rotas de navegação quem vinham da Bahia ou Rio de Janeiro, no sentido Sul, ou vice-versa, subindo em direção ao norte, vindo do Rio da Prata, avaliavam-se os melhores pontos de atracagem àqueles de aguada, parada para embarcações, considerando-se porto natural por excelência. A forma das suas baias, a população ali presente e mais ainda a geografia Atlântica de uma ilha de tipo continental, com regimes de ventos e marés, tornava ponto de acolhida nas rotas das navegações, atribuindo-lhes funções de destaque. E como bem diretamente já se afirmou “[...] não há como se desconsiderar o papel do mar como meio de circulação geográfica." (MORAES, 2010, p.308). É nesse meio de circulação geográfica que a ilha de Santa

\footnotetext{
55 “[...] conceito mítico duma Ilha Brasil, tão divulgado desde os meados do século XVI, pela cartografia portuguesa, e da qual os cartógrafos franceses, holandeses e alemães à compita o copiaram." (CORTESÃO, 1955, p.67).
} 
Catarina passou a ser visitada, conhecida e ponto de apoio na rota das navegações; sua existência vista como atrativa. Os usos dos espaços insulares a colocaram no importante circuito das rotas feitas.

Uma quantidade de viajantes, atraídos principalmente pelo Rio da Prata e imediações, deixou relatos e impressões diversas, muitos deles coligidos no livro Ilha de Santa Catarina: relatos de viajantes estrangeiros nos séculos XVIII e XIX, obra organizada no século XX, por Martim A. P. de Haro (1996). Nela percebe-se tanto presença de variadas origens da nacionalidade dos estrangeiros, como também trechos denunciadores da presença e de aspectos da colonização portuguesa, quando, por exemplo, Amédée François Frézier na primeira década dos setecentos, assim disse da ilha de Santa Catarina: "É uma floresta contínua de árvores verdes o ano inteiro." Ainda segundo o mesmo viajante, os moradores de "12 ou 15 sítios dispersos aqui e acolá à beira mar nas pequenas enseadas fronteiras à terra firme"; ali viviam portugueses, parte de europeus fugidos (ou desterrados), alguns negros "vê-se também índios, alguns servindo voluntariamente aos portugueses, outros que são aprisionados em guerra." (FRÉZIER, 1996, p.23).

Nos relatos de alguns viajantes no início do século XVIII, percebem-se expressões tanto de temor como de admiração nas descrições feitas - elogiando a exuberância ou considerado perigo - das matas da Floresta Ombrófila Densa (Mata Atlântica) da ilha e, de partes do litoral, enxergado pela navegação costeira realizada.

Chegava-se a descrever como se fosse uma elevada excessiva presença de vegetação, causadora de temor e também como barreira e refúgio. Apresentada em constantes relatos a sugestão de não freqüentar as áreas de cobertura vegetal, associadas ao desconhecido; tais opiniões negativas, invertiam-se quando avistavam próximo as florestas os elogiados pássaros, as árvores e demais plantas conhecidas pelos próprios viajantes, ainda mais se pensadas como úteis. Diz Frézier, (1996, p.22): “[...] entramos em uma propriedade abandonada de onde carregamos para nosso escaler quantidade de laranjas doces, limões e grandes limas."

Pareciam se impressionar com a quantidade de animais, inclusive para se abastecerem, “chamou-nos a atenção", relatou Frézier em passagem de 1712, "manadas de bois selvagens." Mas pareciam ver, ao menos assim descreveram, as terras cerradas com matas como lugares não indicados a frequentar. Pelo motivo de serem áreas consideradas fechadas de mato, viajantes diziam, quem ali estivesse pela exuberância da floresta poderia considerar-se protegido. Segundo entendeu Georg Shelvocke quando 
aportou em 1719: "A ilha é toda coberta de matas inacessíveis, de forma que, com exceção das plantações, não existe uma só clareira nela toda." (SHELVOCKE, 1996, p.46).

É perceptível nos textos dos viajantes, como muitos esforçavam-se a darem a entender terem lido relato de alguém já passado por onde descreviam estar. Faziam constantes lembranças de trechos percorridos por outros e dos dizeres dessas presenças prévias. Inclusive, pelas referências feitas, "citavam-se" uns aos outros nos seus relatos de impressões. Mencionavam paisagens e situações ou momentos e espaços relacionando, às vezes, seu depoimento em texto com "bibliografia" de outro viajante, previamente passado por ali. Mesmo sendo muito influenciados uns nos informes dos outros, também se fazia críticas, inclusive, satíricas, permitindo constatar uma relativa autonomia intelectual e perfil autoral nas opiniões de alguns daqueles viajantes. Quando se encontravam no porto de parada, também os próprios viajantes se avaliavam; descreviam-se entre eles. Teciam comentários e opiniões jocosas. Como fez Betagh (1996, p.56) quando não deixa de ser atento e irônico na forma de relatar a presença de cristãos endinheirados de passagem pela ilha, provavelmente vindo de regiões auríferas, mineradoras e indígenas em direção à Europa:

Eu devo informar ao leitor que La Jonquière tinha a bordo de seu navio uma boa soma de dinheiro real e aproximadamente vinte padres, alguns dos quais tinham estado por muitos anos no Peru, Chile e no Paraguai, como missionários propagadores da fé. Lá haviam enchido seus bolsos, sendo que o evangelho provara ser um negócio lucrativo. (BETAGH,1996, p.56)

Essa prática de associar impressões com autores de outros relatos preexistentes e às vezes, até citações de textos publicados, conduziram, direcionando de maneira quase homogênea, ou de maneira muito parecida, às impressões dos próprios viajantes. Muitos vinham com pré-concepções, bem informados previamente e dispostos a encontrar o mundo visto pelos relatos de outros aos quais, se utilizavam como fontes.

Parece se conceberem (se viam) como viajantes; percebiam-se em movimento, denunciavam os Outros e o enriquecimento de menor status, como na citação última, acima feita. Mesmo assim, embora fossem pessoas diferentes e inclusive, passando em épocas distintas, às vezes, repetia-se algum relato e impressão, para dizer como algo continuava igual. Citavam-se depoimentos, como espécie de alerta, dizendo dos riscos por quem ali passara antes, ou ainda, de como já havia mudado alguma característica, 
anteriormente descrita por algum outro viajante. ${ }^{56} \mathrm{E}$ acima de tudo, criavam-se tantas expectativas prévias com esses relatos, só comparável com a quantidade dos desejos em instruir e prevenir: "[...] nós deixamos sem arrependimento uma ilha, da qual nós tínhamos formado as mais elogiosas ideias, mas que, quanto aos víveres, aos refrescos e à hospitalidade, não corresponderam de maneira nenhuma à nossa expectativa." (ANSON, 1996, p.72). Claramente, nem todos concordavam entre si.

Muitos também pareciam desejar seus relatos como legítimos e servindo para algo, úteis, ao precaver. Descrevendo alertas, manuais indicativos de como proceder nos mares do hemisfério sul da América "[...] nós chegamos ao ancoradouro na Ilha de Santa Catarina e vimos que ele correspondia muito bem às nossas expectativas; lá existia madeira suficiente, mas que deveria ser cortada com nossas próprias ferramentas, já que os ilhéus não as possuíam." (SHELVOCKE, 1996, p.33). Nos relatos de alguns viajantes, aparecem elogios a quem deixara úteis informações e precisas instruções.

A pesquisadora Luciana Rossato (2007) estudou os olhares dos viajantes e algumas das opiniões tão comuns entre eles e as mútuas referências ou trocas de informações. Comenta ela, como uma estratégia dos próprios relatos e intenção de mencionar outro viajante já tendo percorrido o palco e lugares relatado, feito de maneira tão fiel e semelhante descrição, cujo estatuto em outro paradigma poderia até ser apontado como uma cópia: "A despeito da autoria ser nomeada, constata-se a repetição de ideias em comentários sobre determinada região que, numa outra área de conhecimento, poderia ser considerada como plágio." (ROSSATO, 2007, p.18). A estratégia de citar ou copiar um prévio relato, buscava atingir um estatuto de autoridade, maior reconhecimento e credibilidade ao próprio depoimento escrito: "Nesse aspecto, a repetição de comentários e, muitas vezes, de opiniões sobre o outro constitui um aspecto que contribui para reforçar a veracidade do texto produzido." (ROSSATO, 2007, p.18). Buscava-se reconhecimento ao mencionar autoridade e estatuto de verdade para o dito.

A densidade das florestas como potencial a dar segurança aos moradores embora a mesma mata vista como fechada, considerada perigo para quem não soubesse os segredos de ali sobreviver - é um exemplo dessa repetição dos comentários entre vários e diferentes viajantes. Se na passagem em 1719, viajante Shelvocke (1996, p.47) diz: "Não têm eles, nenhum local que possam chamar de 'cidade', nem tampouco

\footnotetext{
${ }^{56}$ Exemplo da referência de outro viajantes citado no texto, desprende-se, ainda, do relato de Shelvocke Betagh (Apud Haro, 1996, p.47): "Quantos às excelentes casas de moradia mencionadas pelo Sr. [Amédée François] Frézier [que esteve na ilha em 1712], nenhum de nós logrou ver nenhuma delas."
} 
qualquer fortificação de qualquer espécie, com exceção das matas." Esse mesmo viajante argumentou como estaria na Mata Atlântica a proteção para quem precisasse, por exemplo, refugiar-se: "Estas [florestas], com efeito, são um ótimo refúgio, para onde podem escapar com segurança em casos de ataques." Tal referência, menção ou metáfora das matas como uso de sistema de defesa natural, aparece no relato de Frézier (que Shelvocke e outros mencionam em seus textos) passado pela ilha sete anos antes, em 1712. Quando viajante diz como as pessoas possuíam poucas espingardas e rara pólvora; viviam tranquilamente, pois tinham a floresta: “[...] estão, no entanto, suficientemente defendidos pelas matas onde uma infinidade de espinheiros de toda espécie as torna quase que impenetráveis, de sorte que, tendo sempre a retirada segura [...].” (FRÉZIER, 1996, p.23).

Outro aspecto, muitíssimo regular nos depoimentos escritos dos viajantes, estava na satisfação de uma boa parada das embarcações da ilha. Também nesse aspecto mencionam-se "a si mesmos" ou uns aos outros para reforçar, ou comparar a qualidade das informações ou credibilidade dos relatos dos viajantes. Algumas vezes também tais menções envolviam detalhes logísticos, cartográficos, ou melhor, as práticas para evitar encalhes, profundidade das baias, alertas de possíveis naufrágios ou outros problemas nas embarcações. O que e onde era mais pertinente fazer quando a embarcação ancorada e recomendações à tripulação após chegada em solo, também apareciam em seus textos.

É importante entender a territorialidade marítima conformada como certo lugar de parada, portanto, de encontros entre os viajantes e constante interação entre eles próprios. Vindos de lugares diferentes, com destinos e intenções diversos; estratégico lugar para as rotas. Tendo diversidade de frequentadores, reforça um caráter badalado da ilha. Shelvocke (1996, p.37) conta da presença de uma embarcação com bandeira da França, comandado pelo navegador Dumain Girard e da interação que tiveram, "Eu" escreve o chefe da tripulação inglesa - "também comprei dele 60 queijos e 300 libras de manteiga para completar o nosso estoque de provisões." Assim, viajantes realizavam seus abastecimentos vários, inclusive comercializações direta, entre as próprias embarcações e não, apenas, entre populações locais e viajantes, ocorrendo transações comerciais entre os próprios europeus, passando a dar uso próprio (ou influenciando) nas dinâmicas das relações sociais com os espaços ilhéus.

Tanto os relatos de época, como também a literatura já muito bem cobriram a atração da ilha na recomposição das embarcações para continuar viagem; esse é um tipo de territorialidade dos usos socioespaciais da ilha. É importante mencionar como "O 
litoral é, contudo, uma zona de contato não apenas na perspectiva da geografia física, mas igualmente na ótica do estudo da relação espacial entre sociedades." (MORAES, 2010, p.308). Elenco a seguir, a partir de análise realizada dos relatos de viajantes, alguns aspectos mencionados nos usos e paradas dos considerados portos naturais da ilha de Santa Catarina e as justificativas de ali aportar:

Box 1: Alguns fatores e destaques na constituição de uma territorialidade marítima na ilha Abastecimento alimentar (carne, legumes, frutas, frutos do mar, peixes), para consumo próprio da tripulação, tanto para ampliar estoques das embarcações como evitar consumir o que as embarcações portavam, incentivava-se consumo disponível nos recursos naturais da ilha e mediações;

Acesso a água potável e outras bebidas tais como vinho, cachaça, ou líquidos como tipos de vinagres para limpar embarcações, por exemplo;

Elogio à comunidade local: seja algumas autoridades, população "acolhedora" (ou ao menos, vista como não hostil) e disponível às trocas mercantis, escambo e demais apoios (ou mesmo alguns serviços/atenção) aos viajantes; para reparos

Acesso à madeira, matérias primas e alguns outros materiais/ferramentas

Considerações positivas de diversidade de produtos a serem encontrados.

Fonte: organizado por mim, com base nos relatos de viajantes acessado em HARO (1996).

Não havia apenas passagens instantâneas ou momentâneas do curto tempo de parada. Às vezes as condições climáticas, as estações do ano ou os regimes de navegação favoráveis ou não, definiam maior ou menor tempo de permanência na ilha. Além de completarem seus estoques e aprovisionamentos, relatos afirmam chegarem até a realizar produções agrícolas no tempo em que estavam atracados. Um viajante que pretendia ficar uns dois ou três meses ali aguardando “[...] uma melhor época para navegar ao largo do Cabo Horn. Por isso, tão logo lançou âncora, mandou alguns dos seus homens cavarem uma pequena horta e semearem alguns alfaces e outros tipos de verduras para salada." (SHELVOCK, 1996, p.37). Em uma concepção contemporânea, hoje, se poderia dizer que muitos desses viajantes fizeram da ilha lugar de moradia, mesmo não permanente, mas que deixavam marcas: "Tem-se naturalizado algumas árvores frutíferas de Portugal" (CASAL, 1943, p.134). Manuel Aires de Casal (1943, p.124) assim disse de quando registrou a sua passagem: "Todas as hortaliças de Portugal aqui prosperam, principalmente as cebolas." 
A interação entre viajantes/tripulação com a ilha era intenso, envolvendo diferentes aspectos e sujeitos, inclusive um consumo complexo de recursos não desprezíveis. Os relatos de viajantes ajudam a visualizar a apropriação e relação mercantil realizada por eles: “[...] bem em frente à parte extrema sul da Ilha de Santa Catarina, eles têm gado preto em grande número, algumas cabeças das quais nos foram fornecidas e que compramos a preço razoável.” (SHELVOCKE, 1996, p.47). Vários relatos dedicam-se a descrever e a tentar convencer como a ilha era um lugar favorável ao abastecimento, "Eles desfrutam das bênçãos de uma terra fértil e um ar muito saudável e não têm falta de nada, a não ser de roupas." (SHELVOCKE, 1996, p.47).

Aspectos até aqui elencados e citados sobre a ilha são para dizer da territorialização implementada a partir de uma porção de terra no mar. Trata-se de um período "quando as condições naturais prevaleciam na definição das 'vocações locais'." (MORAES, 2014, p.28). É sobre o que talvez se pensasse como vocação dos aspectos naturais da ilha, que possibilitou nela instituir uma territorialidade de tipo marítima.

Não bastava para a apropriação territorial da metrópole, que quem na ilha estivesse e em contato com quem por ali parava embarcações, se sentisse protegido por densas matas ou pudesse buscar refúgios ao interior. Ser um bom lugar para as embarcações e sua condição favorável a tornam de interesse não apenas para a navegação, mas para o poder. Era necessário, na visão colonial, o próprio Império precaver-se e, fortificar, como um lugar de defesa. E não para defender a própria ilha apenas e estritamente, mas para, do lugar dela, apoiar toda vontade de domínio da macro região da bacia do Rio da Prata e da parte meridional da América portuguesa. ${ }^{57} \mathrm{~A}$ ilha passa a ser colocada com uso indispensável no apoio da manutenção do domínio.

Então passa-se, ao que estou denominando de uma segunda camada de territorialização, agora mais claramente Estatal (período que vai se somar à centralidade da navegação/localização da ilha), a escolha da mesma como um ponto de defesa e estratégia militar portuguesa. Passa a ser planejada como ingrediente, ou melhor, uma peça indispensável no exercício e estratégia de defender e conservar os domínios meridionais da metrópole (SALOMON, 2002, p.12). É aqui um particular importante na base territorial de Santa Catarina, a ilha passa a ser Ilha: entra como elemento de destaque na maior precisão do que venha a ser governar: "[...] governar ligada ao

\footnotetext{
${ }^{57}$ A partir daí (como discuto no próximo tópico desse capítulo) "A Ilha de Santa Catarina" - afirma a tese de doutorado Augusto da Silva (2008, p.14) na qual concordo com as interpretações do autor - passa a ocupar "posição peculiar no Sistema Colonial. Sua principal função era servir de base militar para a defesa de espaços mais valorizados do ponto de vista econômico." (SILVA, 2008, p.14) (destaques meus)
} 
exercício de defender, conservar e ordenar os domínios do soberano, a qual se estende até o início do século XIX.” (SALOMON, 2002, p.65).

Vale dizer novamente, lugar favorável de passagem, parada e ponto de uso como porto, constitui um tipo destaque (e mesmo "lugar de encontro") naquela época de predomínio de regime de navegação, como tratei até aqui: de uma territorialidade marítima. Agora, entramos no Estado como agente modelador direto das atribuições ao espaço, cuja função primordial passa a ser ajudar a resguardar. Aqui “nascerá a ruga."

\section{A certidão e a toponímia, Santa Catarina: a ilha que nomeou uma Província/Estado}

Na Carta Régia de 11 de agosto de 1738, Dom João V ordenava que fosse separada de São Paulo e submetida ao Rio de Janeiro a Ilha de Santa Catarina. O momento era de centralização de um poder das capitanias do Centro Sul, tendo a figura o governador Gomes de Freire Andrade e a sede o Rio de Janeiro. Tal procedimento tem sido identificado como a certidão de nascimento da Capitania da (Ilha) de Santa Catarina (SILVA, 2008, p.57). Seja para nas narrativas de efemérides ou em discussão histórica, 1738 costuma ser apontado como importante marco de circunscrição de atributos próprios e políticos ao espaço, Santa Catarina. ${ }^{58}$ Mas estava bem distante de ser o território catarinense de hoje em dia, longe disso. Embora defendo a ideia de na longa duração da capital, ter ali seu momento de início, com territorialidade militar.

A bem elaborada tese de doutoramento de Augusto da Silva (2008), trata a respeito do caso da territorialização militar Estatal de Santa Catarina, bastante localizada inicialmente na Ilha de Santa Catarina e seu continente frontal próximo, principalmente com a decisão de ali realizar a implementação de fortificações e maior controle do sul da América portuguesa. 59 "Inicialmente a Capitania de Santa Catarina limitava-se ao território insular e continente imediato, em 1742 passa a incluir Laguna,

\footnotetext{
${ }^{58}$ Trecho (publicação comemorativa) em que a carta régia é vista como primitiva Santa Catarina: "Dom João $5^{\circ}$ promulgou, em 11 de agosto de 1738, a Carta Régia, ordenando que o brigadeiro José da Silva Paes passasse à Ilha para fortificá-la, separando de São Paulo a Ilha de Santa Catarina, colocada sob o governo do Rio de Janeiro, unificando assim o comando litorâneo até o rio da Prata. Este documento marca a criação da capitania subalterna de Santa Catarina, especificando que Silva Paes exercesse o seu governo, tornando possível assim, embora ainda não estivesse integrado todo o atual território catarinense, considerar o brigadeiro como sendo o primeiro governador de Santa Catarina." (VIEIRA FILHO, 2001, p.86). (destaques meus)

${ }^{59}$ Orlando Valverde (1957, p.264) assim ressalta a importância da maior Ilha do Atlântico Sul da América portuguesa e o motivo pelo qual os portugueses atribuíram a mesma um papel estratégico-militar essencial para a manutenção, conquista e posse da apropriação espacial da macro-região do Prata: "O Desterro era a chave das comunicações com o Prata, por isso, os portugueses fortificaram toda a ilha, mais do qualquer outra parte da costa sul do Brasil [...]. A $\underline{\text { ilha passou então, a ser o trampolim das }}$ arrancadas luso-brasileiras para o sul." (VALVERDE, 1957, p.264). (destaques meus)
} 
em 1750 São Francisco e em 1820 o restante do território catarinense, abrangendo Lages [...]." (LIMA, 2002, p.60).

Quando no imediato da criação da capitania subalterna e governo na Ilha, não significa jurisdição para além de si mesma e vizinhança. Aos poucos, a ela vão sendo agregado outros espaços a serem administrados, ampliando possibilidades de maiores áreas subordinadas ao governo ali localizado. ${ }^{60}$ Mas não era assim antes da criação da praça militar na Ilha, pois “Até 1738, a Ilha de Santa Catarina vinha sendo comandada por um sargento-mor, subordinado ao capitão-mor de Laguna e, ambos, ao governador da capitania de São Paulo." (SILVA, 2008, p.49). Havia uma classificação da hierarquia dos lugares, em ordem de importância na lógica colonial. Em 1726, quando a então (desde 1714) freguesia, de Nossa Senhora do Desterro havia subido ao status de Vila, a autoridade que "assim a distingue" o faz em Laguna. ${ }^{61}$ Se acompanharmos, na ordem temporal da criação oficial de algumas Vilas, descrita por Aroldo de Azevedo (1956), será perceptível como Desterro assumiu essa posição, após São Francisco (no século XVII) e Laguna já terem elas mesmas acessado a essa categoria.

Tabela 2 Ano de instituição de Vilas na hierarquia urbana colonial, segundo AZEVEDO (1956):

\begin{tabular}{|ll|}
\hline Ano & Nome \\
\hline 1653 & Nossa Senhora do Rosário do Paranaguá (atual Paranaguá) \\
\hline 1660 & Rio de São Francisco do Sul (atual São Francisco do Sul) \\
\hline 1693 & Nossa Senhora da Luz dos Pinhais de Curitiba (Curitiba) \\
\hline 1714 & Laguna \\
\hline 1726 & Nossa Senhora do Desterro (atual Florianópolis) \\
\hline 1751 & São Pedro do Rio Grande do Sul (atual Rio Grande / RS) \\
\hline 1774 & Lages \\
\hline 1797 & Antonina \\
\hline 1798 & Castro \\
\hline 1808 & Porto Alegre \\
\hline
\end{tabular}

Na ilha de SC a vila reconhecida em 1726. São Francisco e Laguna foram vilas, antes de Desterro.

Na tese intitulada, A Ilha de Santa Catarina e sua terra firme: estudo sobre o governo de uma capitania subalterna (1738-1807), o pesquisador demonstra como

\footnotetext{
60 "Quando a capitania de Santa Catarina foi criada em 1738, tornando-se independente da capitania de São Paulo, porém subalterna à do Rio de Janeiro, sua extensão territorial estava limitada às proximidades da Ilha de Santa Catarina. As vilas de Laguna e São Francisco do Sul ainda compunham o território paulista. A primeira foi incorporada à capitania de Santa Catarina em 1742, e a segunda em 1750" (BRÜGGEMANN, 2008, p.39). (destaques meus)

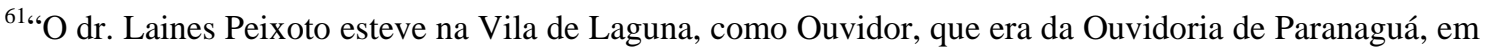
1726. Nessa ocasião, a 27 de março, elevou à categoria da Vila a povoação da Ilha de Santa Catarina, sob a invocação de Nossa Senhora do Desterro." (BLUMENAU EM CADERNOS, Tomo XIII nº1 janeiro 1972, p.16)
} 
principalmente a partir de fundação (quase em frente a Buenos Aires na outra margem do Rio da Prata) da Colônia do Sacramento por Portugal em 1680, desperta uma maior atenção da Espanha em relação ao Atlântico Sul e abre um processo de longas disputas entre os dois países Ibéricos que adentra até o começo do século XIX.

A Carta Régia cria a Ilha de Santa Catarina como uma capitania e a coloca na esfera do (ou no campo de força submetida ao) Rio de Janeiro, sendo resultado tanto do: a) contexto geopolítico de disputa entre as Coroas espanhola e portuguesa, assim como da b) organização interna da própria relação colônia e metrópole. Promove-se uma territorialidade diferente, dando uso mais militarizado da Ilha, até então bastante central no regime de navegação, como já tratado. Na afirmação de Marlon Salomon (2002), até então a ilha teria desempenhado um papel pouco importante do ponto de vista dos interesses portugueses. Próximo do insignificante para a administração colonial, era usada como um deposito de indesejados, "[...] o poder lhe reserva o lugar de exílio da desordem.” (SALOMON, 2002, p.12). A não ser para os usos da navegação, ela não parecia muito importante:

Durante muito tempo, ela esteve esquecida pela soberania portuguesa: no final do século XVII, por exemplo, os primeiros súditos que nela haviam se acomodado, perderam quase todas as suas vidas durante uma pilhagem empreendida por piratas ingleses ou holandeses, sem que isto tenha lhe chamado à atenção. (SALOMON, 2002, p.12).

Na tese de Salomon (2002), a mudança esteve em passar a tratar a ilha como apoio de governança "[...] relacionada à defesa e a conservação do território. O que se deve estar em estado de segurança é o espaço; todas as maneiras possíveis de se defende-lo nada mais são do que um esforço de torná-lo seguro, protegido do inimigo exterior que o ameaça." (SALOMON, 2002, 246). Estou interpretando a criação da capitania subalterna da Ilha de Santa Catarina como a sobreposição da territorialidade marítima - central para a navegação - por uma territorialidade militar, promovida com lógica defensiva do Estado colonial. Nesse processo dos usos que configuram seu território de maritimidade para militar, vai receber destaque bem maior.

O papel secundário da Ilha começa a mudar, entretanto, a partir do momento em que os novos povoados fundados no sul e, também, a Ilha de Santa Catarina passam a desempenhar a função de entreposto de apoio na preparação de materiais de construção dos mais diversos para a instalação da Colônia do Sacramento. (LIMA, 2002, p.55) 
Segundo argumento de que São Paulo ${ }^{62}$ já aparecia no momento uma capitania com menor capacidade de controle, no olhar do Conselho Ultramarino, somadas outras razões de centralização administrativa e do poder, foi realizado a transferência de algumas áreas a serem governadas (submetidas) por esferas metropolitanas sediados no Rio de Janeiro. Logo na primeira década do século XVIII a coroa portuguesa compra as Terras de Sant'Ana que no século XVI haviam sido concedidas ${ }^{63}$ a Pero Lopes de Souza (irmão de Martim Afonso de Souza) e, ao comprá-las, mantém Santa Catarina na jurisdição da Capitania de São Paulo, criada em 1709. Depois, com a reestruturação administrativa do controle régio, ambas são (transferidas) submetidas, no intervalo de uma década, para o Rio de Janeiro:

[...] modo de ampliar ainda mais o controle régio sobre determinados espaços estratégicos do império português, Dom João $\mathrm{V}$ tomou uma série de medidas que reduziram o poder jurisdicional dos capitães-generais de São Paulo: a antiga 'Minas de Ouro', criou a capitania geral 'das Minas' (1720); anexou a esta a administração das minas de Goiás e Cuiabá (1738), transformando-as, dez anos depois, cada qual, em capitanias gerais; transferiu para a jurisdição do Rio de Janeiro a Ilha de Santa Catarina (1738), o Rio Grande de São Pedro (1738) e Laguna (1742); e, por fim, o próprio governo de São Paulo, passou a ser uma dependência [em 1748] administrativa do Rio de Janeiro. (SILVA, 2008, p.45).

Com base naquele documento da transferência da esfera de São Paulo para maior centralização no Rio de Janeiro, a literatura regional costuma projetar a primeira manifestação de uma ("gênese" de) unidade territorial de Santa Catarina. Se bem que, de alguma forma - mesmo que não totalmente efetiva - o tratado de Tordesilhas e as Capitanias Hereditárias também já haviam atribuído linha divisória e empoderamento dessa parte do espaço sul da América portuguesa, inclusive, cartograficamente ${ }^{64}$ localizada. "O primeiro mapa publicado na Europa que traz o nome de Terra de Sant'Ana referindo-se a esta parte do litoral sul brasileiro, é um mapa de Juan de La

\footnotetext{
${ }^{62} \mathrm{O}$ autor do livro "História dos Estados brasileiros" faz menção cronológica das áreas criadas a partir de espaços que conformaram, em certo período, a capitania São Paulo. Quando menciona Santa Catarina, usa 1738 como o marco temporal: "Verdadeiro fracionamento do espaço tradicional da capitania de São Paulo, com a formação de Minas Gerais (1720), Santa Catarina e Rio Grande do Sul (1738), Goiás e Mato Grosso (1748). Por fim, São Paulo passaria à jurisdição da capitania do Rio de Janeiro, em 1748, vindo a recuperar sua autonomia somente depois, em 1765.” (ALVES FILHO, 2000, p.209)

63 “[...] o rei de Portugal, pela Carta Régia de 21 de janeiro de 1535, doou a Pêro Lopes de Souza [...] áreas de terras: uma de 30 léguas de costa, em Itamaracá [Baía da Traição e Igaraçu]; [Capitania de Santo Amaro: Caraguatatuba e Bertioga], e outra de 50 léguas de costa, no Sul, que seria a Terra de Sant'Ana." (PIAZZA, 1970, p.27-28)

${ }^{64}$ Piazza (1970, p.28) afirma que o nome terras de Sant'Ana também se repete no planisfério de Alberto Cantino datado de 1502, nele "trazendo outras informações referentes ao litoral catarinense, que foram fornecidas a esse cartógrafo por Américo Vespúcio.”
} 
Cosa, publicado exatamente em 1500." (PIAZZA, 1970, p.28). E menos de três décadas depois, "Em 1539, o Mapa Mundi de Diego Ribeiro, sucessor de Caboto como Cosmógrafo Real de Carlos I, em Sevilha, fez constar, pela primeira vez a denominação de Santa Catarina para a ilha e a baía que a acompanha." (CORRÊA, 2007, p.74). Há quem diga ter sido em 1526, a ilha nomeada de Santa Catarina, tendo aparecido alguns anos antes, em 1519 grafado pela primeira vez em um mapa como Ilha dos Patos. (LIMA, 2002, p.52-53). E foi em 1534 que a ilha foi integrada na capitania concedida.

[...] antes da efetiva fixação dos exploradores europeus, a ilha era uma densa floresta habitada por índios denominados carijós, inçada de onças e veados, que a chamavam Meiembipe (montanha ao longo do canal, sendo que ao canal chamavam Jureremirim (boca pequena, ou simplesmente "Estreito"). (LIMA, 2002, p.51).

A respeito dessa parte meridional da América, é preciso lembrar, Portugal conhecia tão bem, pois, o ponto final do meridiano traçado, conforme registra Oswaldo Cabral (1968, p.14), nenhuma outra donatária foi concedida ao sul da capitania (de Sant'Ana) doada a Pero Lopes. E como lembra nossa vulgata, se limitada a essa área traçada pelo Tratado de Tordesilhas, "Santa Catarina teria apenas cinco por cento do seu atual território." (SACHET; SACHET, 1997, p.17). A partir do fim da União Ibérica - a "junção" das coroas tira sentido do Tratado de Tordesilhas - e principalmente, umas cinco décadas a partir da fundação da Colônia do Sacramento em 1680, o olhar voltado para a ilha tende a instituí-la dentro da lógica de defesa e proteção, uma territorialidade de base militar Estatal, colonial. ${ }^{65}$

Mas antes de submetida ao Rio de Janeiro, é central mencionar como alguns autores apontam - no que considero territorialidade marítima - a influência de São Vicente e São Paulo ter sido de relevância na área hoje denominada litoral catarinense. Identifica-se em alguma revisão de literatura de história de Santa Catarina, três argumentos principais ou fatores apontados para a "polarização" ou grande presença vicentista/paulista. Primeiro o fato dos irmãos Sousa: Martin Afonso e Pero Lopes possuírem faixas donatárias contíguas. Segundo devido aos descendentes de ambos manterem-se em uma longa disputa jurídica de herança, faz com que tanto as terras de

\footnotetext{
${ }^{65}$ Silva (2008, p.64) assim interpreta a territorialidade de base militar: "Segundo classificação de Antonio Carlos Robert Moraes, toda a construção de território associa e hierarquiza três dimensões: militar, jurídica e ideológica. Em alguns casos pode ocorrer de haver uma identidade fortemente marcada que se transforma no meio jurídico e consegue se afirmar, em algum momento, diplomática ou militarmente; em outros, a conquista do espaço se impõe por um aparato militar e uma legislação forte, com a criação da identidade a posteriori, a partir do território. Este parece ter sido o caso de Santa Catarina, não obstante a formação militar e jurídica ser posterior à instalação dos três primeiros povoados.” (SILVA, 2008, p.64).
} 
Martin e Pero fossem "juntadas"66 - por legado - indo parar nas mãos de D. Lopo de Sousa (CABRAL, 1968, p.15) que as vende à coroa portuguesa em outubro de 1709 e tendo a Coroa realizado as escrituras em 1711; o terceiro elemento importante se deve às fundações dos primeiros ${ }^{67}$ núcleos de povoamento colonizador. A constante presença e exercício de poder, como apreender indígenas, por exemplo, pelos vicentistas nas áreas denominados atualmente de Santa Catarina, torna regular suas presenças e influências nos usos desse espaço litorâneo.

No século XVII ocorrem três fundações de povoados no litoral de Santa Catarina (São Francisco do Sul; Desterro/Florianópolis; Laguna) que representavam o interesse da colonização portuguesa nessas áreas. Nas palavras de Paul Singer (1968, p.82): “A partir de São Vicente, pequenos grupos de colonizadores foram descendo a costa e ocupando alguns pontos do litoral: São Francisco do Sul em 1645, Desterro (Florianópolis) presumivelmente em 1651, Laguna em 1676.” Enfatizando a ideia de influência de Portugal no patrocínio dessas fundações, a opinião de Orlando Valverde:

[...] adotaram as autoridades portuguesas uma política firme e conseqüente, embora disfarçada, de ocupação do litoral e do planalto [meridionais], ora tomando diretamente a iniciativa, a maioria das vezes, porém, incentivando a gente de posses de São Paulo a fazê-lo, seduzida pelas concessões de sesmarias e de títulos e cargos honrosos. (VALVERDE, 1957, p.107).

É preciso registrar a localização de disputas em que se encontravam as povoações meridionais iniciadas por vicentistas e paulistas, naquele contexto de incerteza de domínio do Atlântico Sul, entre as competições das coroas Ibéricas pois, se "São Vicente é indiscutivelmente português; o rio da Prata é castelhano. Entre os dois pontos, estendia-se o largo território de soberania ainda duvidosa, muito pouco habitada

\footnotetext{
66 Algumas vertentes de história de Santa Catarina vão buscar descrever a esfera de influência dos vicentistas nas fundações e domínio na capitania chamada de Sant'Ana e depois capitania de Santa Catarina, por exemplo a forma como Oswaldo Rodrigues Cabral (1968, p.15-16) descreve esse contexto: "De sucessão em sucessão, de herdeiro a herdeiro, por falecimento sucessivo dos que diretamente descendiam de Pero Lopes, a sua donatária foi cair às mãos de D. Lopo de Sousa, que já era donatário também por herança, da Capitania de S. Vicente. Juntavam-se assim, nos começos do século XVII, as heranças dos dois irmãos, a de Pero Lopes e de Martin Afonso, o que vem a explicar a influencia que então vieram a ter na vida catarinense, as Vilas de S. Vicente e S. Paulo." [...] "Este, enfadado com longo litígio, que atravessava todo o Século XVII, resolveu vender as terras que constituíam a legítima de Pero Lopes e pediu licença para à Coroa, para aliená-las por 44 mil cruzados a José Góis de Morais. Todavia, o monarca achou que o negócio convinha muito mais à Coroa e, assim, pelo Alvará de 22 de outubro de 1709, resolveu comprar as terras por 140 mil cruzados, tendo sido passada a escritura de venda a 19 de setembro de 1711." (CABRAL, 1968, p.16-16).

67 “A partir de meados do século XVII, grupos partindo de São Paulo, São Vicente e Santos - dessa vez com perspectiva de fixação à terra - deram origem aos povoados de Paranaguá (1648); Nossa Senhora das Graças do Rio São Francisco do Sul (1658); Curitiba (1668); Santo Antônio dos Anjos da Laguna (1682) e Nossa Senhora do Desterro, na Ilha de Santa Catarina (1690).” (SILVA, 2008, p.37).
} 
por europeus, em que se desenrolaria a luta entre as duas correntes colonizadoras." (PRADO JÚNIOR, 2012, p.164).

Essa política de competição ibérica pelo domínio de espaços na América - volta a ocorrer após a União Ibérica e fundação da Colônia de Sacramento, já dito - informa a decisão portuguesa de assentar colonos açorianos e madeirenses nas proximidades de áreas junto de atuação direta das fortificações edificadas. "O interesse efetivo no povoamento do Sul começaria somente a partir da segunda metade do século XVIII, quando sua ocupação se tornaria oficialmente agressiva.” (LIMA, 2002, p.54). A política de colonização com imigrantes vindos das ilhas de Açores e Madeira faz parte desse contexto da territorialização militar.

Dois séculos antes das construções de fortalezas, também em uma conjuntura de competição e conquista territorial, contudo, em um momento ainda de menor definição e anterior a União Ibérica, o navegador veneziano, a serviço da Espanha, Sebastião Caboto, chama a - até então, nominada pelos indígenas como Yurú-Mity (Jurumirim) e conhecida por muitos navegadores/viajantes como Porto dos Patos de - Ilha de, Santa Catarina.

Caboto não emprestou apenas seu nome para a navegação costeira de cabotagem, mas também o nome de sua esposa ${ }^{68}$ a quem ele resolveu homenagear assim chamando a ilha. Se a Carta Régia de 1738 é considerada, como já mencionado, a certidão de nascimento, é essa a toponímia atribuída a ilha vai nomear todo território de Santa Catarina. Não deixa de ser irônico e simbolicamente representativo daquele contexto colonial do século XVI, o fato, bastante aceito entre os pesquisadores, de ter sido o navegador à serviço da Espanha a nomeá-la. Foi no contexto da territorialidade marítima que ela recebe o nome (dado por alguém à serviço da Espanha!), poderia essa toponímia também ser uma rugosidade, se alargarmos o conceito e usos da noção das rugas.

Outra curiosidade dessa nomenclatura a ser mencionada, é o fato de embora o nome do espaço ir "espraiando" junto com o alargamento espacial do poder inicialmente centrado na Ilha, o adensamento populacional maior do núcleo urbano passa a ser

\footnotetext{
${ }^{68}$ Ver, por exemplo João Carlos Mosimann (2004, p.13). A seguir, lembro a interpretação de Caio Prado Junior (2012, p.162): "Em 1526 reaparecem também os castelhanos. Sai naquele ano de Sanlucar de Barrrameda, com destino às Molucas, a expedição de Sebastião Caboto. Desde Pernambuco, onde se detém, vem o almirante ouvindo referências, cada vez mais precisas, das riquezas imensas da Serra da Prata. Faz escala ainda em Cananéia e Santa Catarina - que batiza com este nome em homenagem à sua mulher, Catalina Medrano, cujo aniversário, em 25 de novembro, coincide com a data de sua chegada àquela ilha." (PRADO JÚNIOR, 2012, p.162).
} 
reconhecida e nominada por Desterro (e muito mais tarde, somente no final do século XIX troca-se o nome para: Florianópolis). Em outras palavras, embora o nome tenha sido socialmente usado para toponímia da ilha e depois de toda a Província/Estado, o núcleo populacional que vai se urbanizando na península mais próxima do continente (o centro urbano condensado), acaba por ter um nome diferente do original atribuído a Sebastião Caboto no final do ano de 1526.

A cidade, enquanto, Capital, costuma ser identificada pelo nome (Desterro/Florianópolis) diferente do nome da Ilha que a abriga. Chamo atenção como no Brasil atual, as duas maiores metrópoles do País - e apenas elas - capitais de Estado também levam respectivamente o mesmo nome das suas unidades federativas: São Paulo/SP e Rio de Janeiro/RJ. Teria sido por estar contida dentro da Ilha que a capital de Santa Catarina tem um nome urbano, mas a Ilha que lhe dá sede, tem outro nome (o mesmo nome de todo Estado)? Talvez para diferenciar-se de demais freguesias e apontar como local de comando o núcleo urbano inicial - a cidade sede da paróquia possuir outro nome, sendo que ali, historicamente "[...] a cidade, antes de conhecer o urbanismo, através da geometria, conheceu a fortificação." (SALOMON, 2002, p.240).

A Ilha de Santa Catarina foi uma praça militar, e assim a denominavam muitas das autoridades portuguesas em meados do século XVIII. Entre as fortalezas construídas nas extremidades norte e sul da ilha, no centro dela, encontrava-se a vila de Nossa Senhora do Desterro, tudo sob o comando do Brigadeiro [José da Silva Paes]. (SILVA, 2008, p.163). (destaques meus)

Entretanto, é preciso enfatizar como a expressão para nomear a Ilha de Santa Catarina teve uma temporalidade própria para ser utilizada também ao continente, o que possivelmente permite acompanhar a ampliação da jurisdição da área de poder da governança dessa Ilha que teve dispersado o uso do seu nome.

Santa Catarina significava, no momento da criação do governo, em 1738, tão somente a ilha. Apenas no correr da segunda metade do século XVIII, em decorrência da ampliação dos limites jurisdicionais desse governo - e somente nesse âmbito -, é que a designação começou a significar, além da Ilha, parte do continente. (SILVA, 2008, p.63).

Seja como for, embora tenha se espacializado o nome Santa Catarina para além do título original apenas para Ilha, ela fora geralmente considerada uma capitania subalterna, não apenas ao Rio de Janeiro, ou a São Paulo. Manuel Aires de Casal (1943) anotou, quando passa na já não mais Capitania: "Esta província faz parte do bispado do Rio de Janeiro, é da correição do ouvidor de Porto Alegre.” (CASAL, 1943, p.137). 
Quando da criação em 1723 da Ouvidoria (e chegada do Ouvidor em 1724), separada de São Paulo foi localizada em Paranaguá e cobria jurisdição sobre as vilas da costa sul (CABRAL, 1968, p.49). Mais de duas décadas depois, em 1749, quando da criação da sede do ouvidor-geral em Nossa Senhora do Desterro ela cobriu até a Província de São Pedro. Mas em 1812, retorna a subalternidade pela transferência da sede geral da ouvidoria para Porto Alegre "que passou a ser a cabeça de comarca com as mesmas jurisdições que tinha a anterior.” (SILVA, 2008, p.73). Em 1807, a Capitania de Rio Grande de São Pedro do Sul é "desanexada" pois, também fez parte daquela carta régia de 1738 subalternizá-la ao Rio de Janeiro. Ou seja, quando é elevada na hierarquia (passando) de capitania sujeitada ao Rio de Janeiro para Capitania Geral, leva consigo em 1807 Santa Catarina, que passa agora a ser submetida a então Capitania Geral de São Pedro (SILVA, 2008, p.91).

Na prática, a sub-capitania de Santa Catarina continuou (SILVA, 2008, p.91) prestando contas ao vice-rei do Brasil e a partir de 1808 com a transferência da sede do Império de Lisboa para o Rio de Janeiro, passou a fazer diretamente à corte, o que confirma a emergência de um centro interno na América portuguesa (MORAES, 2009, p.68).

Em linhas gerais, a construção das fortificações (entre 1739 e 1743 foram construídas 4 fortalezas) é a base militar implantada na Ilha e mediações sob o comando do Brigadeiro José da Silva Paes, deveu-se a posição que naquela geopolítica de defesa, considerava a insularidade estratégica, motivo também pelo qual é instalada uma Intendência da Marinha em 1817, que funciona até 1832. (BALDIN, 1980).

Por outro lado, de alguma forma pode-se sugerir como a nomeação e consideração de uma capitania (mesmo subalterna) e sua localização, reforça e mesmo gera uma base de formação territorial, como pode-se apreender com a representação a seguir (imagem 2), do século XIX, mas na qual observa-se um espaço tanto de São Paulo, do Rio Grande do Sul, como de Santa Catarina, bastante delimitados.

Em 1849: as duas comarcas desta Província, criadas em 1833, passarão a denominar-se de Primeira e Segunda Comarcas, e sua divisão será pela forma: a primeira compreenderá os municípios da capital, São Miguel, Porto Belo e São Francisco; a segunda, os municípios de São José, Laguna e Lages. (SALOMON, 2002, p.111).

Embora, em julgamento de hoje, pode-se afirmar que desde 1738 seja considerada um "departamento autônomo", Santa Catarina se caracterizou pela subordinação às capitanias gerais. De maneira que a Independência em 1822, "teve 
grande importância na estrutura de Desterro, tornando a administração pública mais complexa." (LIMA, 2002, p.68)

Título da Imagem 3: Carta Topográfica Administrativa da Província de Santa Catharina, 1848

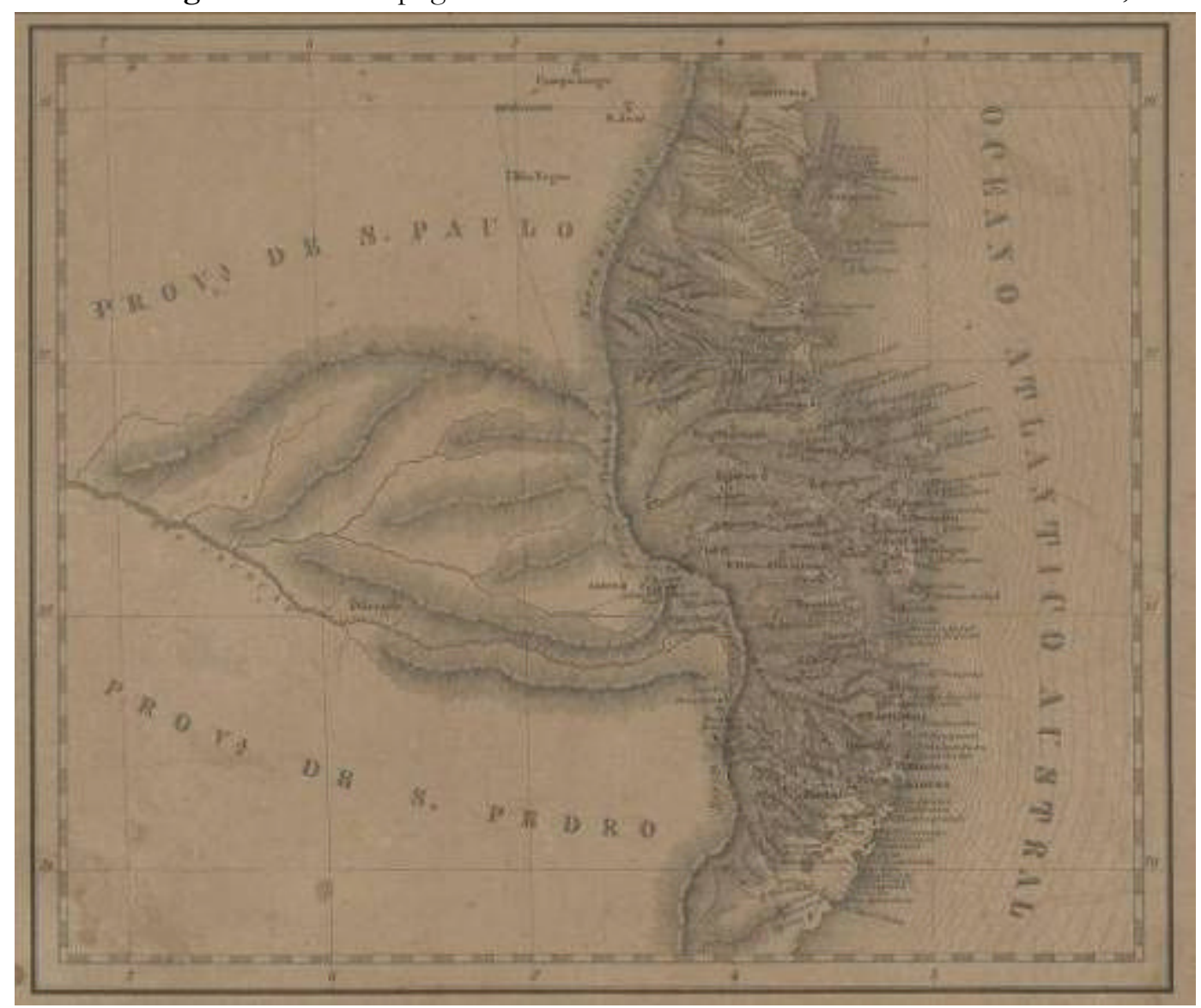

Imagem 3: O presente mapa (autoria de J.H. Leonhard?) apresenta detalhes das 2 comarcas, 3 cidades, 4 vilas e 21 freguesias existentes em Santa Catarina em 1848, assim como linhas demarcatórias entre as Províncias. Disponível no Arquivo Nacional (cuja referência é: F2 MAP229); presente documento partilhado pelo pesquisador Prof Dr. Alcides Goularti Filho, a quem agradeço.

Especialistas opinam como somente a partir de 28 de fevereiro de 1821, Santa Catarina deixa de ser subalterna, pois passa a ter "pelo menos juridicamente condição de igualdade às demais unidades políticas do Brasil, quando as capitanias passaram a denominar-se províncias." (SILVA, 2008, p.91).

Vale enfatizar, há também quem lembre como a Provisão de 20 de novembro de 1749 ao criar a Ouvidoria da Ilha de Santa Catarina, separada da de Paranaguá, teria realizado uma circunscrição de área com autonomia própria para Santa Catarina. Mas é importante registrar como ainda na territorialidade marítima foi a pedido vindo de Paranaguá que se começa a abrir em 1736 um caminho ${ }^{69}$ por terra, ligando São

\footnotetext{
69 "Data de 1736 a Carta Régia do Ouvidor de Paranaguá, Manoel dos Santos Lobato, mandando abrir a estrada do litoral catarinense, ligando São Francisco à Ilha de Santa Catarina. A estrada conservou-se
} 
Francisco à Desterro, assim como, a passagem desta última em 1726 de Freguesia para Vila (como já comentei), aconteceu com a presença de uma autoridade em Laguna, vinda de Paranaguá. É a territorialidade militar que ao demandar maior protagonismo da Ilha, junto com a presença (sede) de um governador militar, lhe atribuirá, em certa medida, maior autonomia.

Entretanto, é preciso ter a noção da imagem ( $\mathrm{n}^{\circ}$ 2) anterior, só fazer sentido após a incorporação de Lages à Santa Catarina, fato ocorrido em 1820, posto que a fundação de Lages por Correia Pinto em 1771 é um empreendimento paulista e localizava a parte mais meridional da Província de São Paulo. "Com o estabelecimento da mineração, por outro lado, progrediu a criação de gado em direção ao sul. Deste movimento, de origem paulista, nasceu Lages, em 1771, no interior do Estado.” (SINGER, 1968, p.82).

A pesquisa da tese de Adelson Brüggemann (2008) defende, como foi a abertura de um caminho entre a Província de Santa Cataria até a Província de São Paulo, fator importante para ajudar a legitimar a área de Lages, como pertencente à Santa Catarina. A fundação de Lages é fruto da política de expansão paulista, particularmente do Governo de Morgado de Mateus. Após a ocupação espanhola da Ilha de Santa Catarina em 1777 e seu retorno ao poder português somente no ano seguinte com o Tratado de Santo Idelfonso ${ }^{70}$ em 1778 é que será progressivamente argumentado como a comunicação por terra entre Lages e Desterro é extremamente estratégica e pertinente para a manutenção de uma base militar que afinal, havia sido testada com derrota, na ocupação espanhola. Era preciso ter resguardado um contato mais efetivo entre Planalto e Litoral.

Tendo formado, inicialmente como uma capitania subalterna, qual legitimação para explicar a carta régia de 1738, como marco fundante de Santa Catarina e, particularmente, da territorialidade militar? Deve-se também tal referência pela implementação de um efetivo governador, de execução das obras para as fortificações e estratégias que configuram uma territorialidade devido a fixação física (mesmo que não completamente autônoma) do poder militarizado.

O Brigadeiro José da Silva Paes, na realização da fortificação da Ilha de Santa Catarina, acreditava na importância de trazer população (não inimiga de Portugal) com moradia regular e constante, seja para auxílio e manutenção desses fortes, seja na

praticamente a mesma até a construção da BR-101. Em muitos trechos, ainda hoje é usado o traçado determinado naquela remota época.” (BLUMENAU EM CADERNOS, Tomo XII nº7, julho 1971, p.135) 70 “.... os tratados internacionais que legitimam as fronteiras: o Tratado de Madri e o Tratado de Santo Idelfonso, que praticamente definiram as atuais fronteiras do Brasil.” (MORAES, 2001, p.112) 
produção de bens de consumo direto: alimentos, retaguarda civil e na execução do uti possidetis. Quando toma posse da capitania, Paes solicitou ao Rei de Portugal a vinda de casais açorianos para colonização, sendo atendido quase dez anos depois, quando, entre os anos de 1748 e 1756 emigraram dos Açores mais de 4 mil pessoas para viverem em terras meridionais da América portuguesa.

Para Paul Singer (1968) essa é uma segunda corrente migratória após, os movimentos de fundações vicentistas e, caracteriza-se pela disputa ibérica:

A segunda corrente seria provocada pela histórica disputa entre Portugal e Espanha pelo domínio do Estuário da Prata. Ao ensejo desta luta, o governo português promove, entre 1748 e 1756, a vinda de alguns milhares de casais açorianos ao Sul do Brasil. Os açorianos aportavam na Ilha de Santa Catarina, sendo estabelecidos na mesma ou no continente, no litoral fronteiriço; parte deles foi enviada a Laguna e outros contingentes ao Rio Grande. Desde modo procedeu-se à ocupação (parcial) da costa catarinense, nos séculos XVII e XVIII, com vicentistas e açorianos. (SINGER, 1968, p.82).

O historiador Walter Piazza (2000, p.28) afirmou que as levas de açorianos instalados em Santa Catarina, estão bastante documentadas historicamente e o mais relevante, tal movimento demográfico criou uma marca importante na configuração territorial de muitas regiões catarinenses, a colonização por imigrantes em pequenas propriedades rurais: "A documentação existente, quer nos arquivos portugueses de Lisboa ou das Ilhas, nos mostram como se formou a cultura da imigração." (PIAZZA, 2000, p.28). Na interpretação de Orlando Valverde (1957, p.113), José da Silva Paes inaugurou um novo ciclo na história do povoamento. Portanto, pode-se ter como hipótese, um fator marcante de um regionalismo catarinense e da territorialidade-estatal de Santa Catarina, a característica da busca, afirmação e controle de domínios através de fortificações e da atração populacional especifica para atender aquela relação de poder no ordenamento do espaço de então. É marcante a ocupação em pequenas propriedades de terra, em uma constituição territorial de corte militar Estatal, colonial.

É todo esse contexto, na minha opinião, que será a base da capital de Santa Catarina ser aonde é, por isso, a "ruga" da sua localização guarda sobre ela alguns outros resquícios como as atuais ruínas em fortalezas e a própria sede urbana na península central. ${ }^{71}$

Mas, se é verdade que o estabelecimento de núcleos e comunidades ruraispesqueiras lança as primeiras bases da caracterização de uma formação social de

\footnotetext{
71 “A península na qual a cidade foi fundada está situada na Ilha, na parte mais próxima do Continente, na sua face oeste, "abraçada” pelas Baías Norte e Sul.” (LIMA, 2002, p.50).
} 
pequenos proprietários de terra, em caráter familiar de produção (campesinato) ou também caracterizada como pequena produção mercantil, não se deve estender ou entender esse tipo de apropriação do espaço como sendo exclusivo e único em Santa Catarina. Muito menos que não significou a colonização em pequenas propriedades uma territorialização profundamente violenta na ótica dos territórios sociais das nações indígenas (seja kaingang ou guaranis), pois passam progressivamente a ser colocados à margem dos projetos de apropriação de terra, portanto, tendo que confrontar com a concepção territorialista do Brasil, como discutido no início desse capítulo.

$\mathrm{Na}$ apropriação de terra e territorializações, as formas de produção e apropriação do espaço, não são necessariamente caracterizadas pelo domínio mais equilibrado e igualitário; e sim também pelas posses de grandes extensões de terras, como ocorre nos campos de cima da serra ou planalto meridional conectado em 1820 à Santa Catarina:

Na região serrana, a apropriação privada das terras teve início com o estabelecimento das primeiras fazendas, em meados do século XVIII, quando muitos particulares já possuíam títulos de sesmarias expedidos pelo governador de São Paulo. As áreas variavam de 5 mil a 20 mil hectares, reproduzindo no planalto serrano o mesmo padrão latifundiário dominante no Brasil. Desde cedo, muitos campos naturais foram ocupados por alguns fazendeiros de Lages e Curitibanos. (MACHADO, 2004, p.74). (destaques meus)

Portanto, se há uma cultura imigratória de colonização em pequenas propriedades dirigidas pelo Estado na territorialidade militar que se inicia no litoral a partir da fundação da capitania, por outro lado, a fundação de Lages no planalto em 1771, significará um encontro e convivência - dentro da área territorial da mesma província - de duas formações sociais, particularmente a partir da desanexação de Lages de São Paulo em 1820 e passando a fazer parte de Santa Catarina. Aliás, passa a fazer parte da área de jurisdição de Santa Catarina, mais do que apenas Lages, somente. Junto é boa parte do Continente do Sul, expressão para se referir ao Planalto Meridional segundo aparecia em documentações do século XIX (SOUZA, 2014, p.92).

Paulistas desciam o planalto em sentido sul para capturar índios e torna-los escravos e passaram a usar dos caminhos e picadas dos indígenas tanto como forma de chegar até eles, como também para deslocamento de animais, como o gado. Por isso, pode-se dizer que na passagem de uma territorialidade marítima, para uma territorialidade militar, progressivamente também vai aos poucos juntando litoral e planalto em uma capitania só, o que em termos temporais do período colonial aconteceu efetivamente durante uns dois anos. Quando Brasil se torna independente em 1822 
Santa Catarina não é mais apenas o litoral, mas há nela uma clara base territorial ibero americana, cuja emergência tentou-se mostrar até aqui.

Nesse primeiro capítulo busquei assentar as bases da emergência (e formação) territorial, traçando um debate da compreensão histórica da criação e particularização do espaço denominado Santa Catarina. Realizado uma revisão de literatura, pretendendo-se sintético, busquei bastante apoio em debates de "fontes secundárias". A resposta tentou alcançar a pergunta, nessa narrativa questionadora: qual história territorial de Santa Catarina? Pensando que é possível ${ }^{72}$ fazê-la, por quê a sua sede de capital foi e é, aonde é... Desde quando começou como uma Província do Brasil Independente (pós 1822), a sede da capital de Santa Catarina é em uma Ilha que recebeu um nome no século XVI, no século XVIII é tornada uma Capitania e o nome dado à Ilha vai se alastrando litoral afora (talvez explicada com agregações que são feitas a partir de São Francisco, Laguna e Lages). A redistribuição da jurisdição da administração traz Lages e sua área do planalto a fazer parte de Santa Catarina em 1820. São essas bases importantes para estabelecimento do território catarinense, argumentei como sendo de uma territorialidade marítima para militar e que estabeleceram camadas de usos importantes na Ilha, formando-a como um ponto chave na longa duração, uma rugosidade, até hoje uma capital.

Santa Catarina vê a definição da resolução da delimitação de sua fronteira oeste com a Argentina resolvida no final do século XIX, mais especificamente no ano de 1895. Quais algumas das repercussões desse resultado, do reconhecimento internacional da fronteira e quais discursos e atributos recaíram sobre consolidação da linha demarcatória entre Brasil e Argentina, mais particularmente entre Províncias do Paraná e Santa Catarina com a Misiones, Argentina? É o que trato a seguir, no capítulo segundo. Vamos a ele.

\footnotetext{
72،Se é possível fazer uma história econômica, uma história cultural, uma história política, também é possível fazer uma história a que eu daria o nome de história territorial, que é tentar captar a formação de uma sociedade abordada a partir de seu território.” (MORAES, 2001, p.105).
} 
CAPITULO II

\section{ALGUNS USOS DA QUESTÃO DE PALMAS E DO LITÍGIO BRASIL ARGENTINA: \\ SENTIDOS E ESTRATÉGIAS DISCURSIVAS A UM FUNDO TERRITORIAL}

\section{Territórios ambíguos, interesses republicanos?}

Parte da imprensa brasileira fez repercutir durante vários dias dos primeiros meses do ano - principalmente fevereiro e março - de 1895, o resultado do laudo arbitral lido em Washington pelo presidente estadunidense, o democrata, Grover Cleveland. As notícias distribuídas naqueles papéis de jornais ${ }^{73}$ que eram impressos às vezes, em mais de um momento de um mesmo dia. Um "periódico" - informava em seu cabeçalho ser do Partido Republicano - de Curitiba, com data de 10 de fevereiro de 1895 fez, de uma notícia em sua primeira capa, uma constatação de vitória pacífica: "A alegria da paz reina por todos os corações brasileiros.” (A REPUBLICA, 10/II/1895, p.01). Era uma meia verdade.

Mal havia passado os quatro anos da simbólica instauração da república em 15 de novembro de 1889. Aqueles primeiros tempos do "novo regime" e em retrospectiva alguém considerou como sendo momento de consolidação da República (HERMES, 1945, p.30), circunstância em "que se estendeu da sua proclamação até a posse de Prudente de Moraes, caracterizado como um período de agitações, revoluções e incertezas [...]." (ANDRADE, 1999, p.109). Substituição da Monarquia ainda não tinha efetivamente se capilarizado, seja pela maneira abrupta e de

\footnotetext{
${ }^{73}$ Jornais paranaenses consultados no arquivo da Biblioteca Pública do Estado do Paraná/BPP, Curitiba. Mais informações, verificar nas referências finais as fontes separadas da bibliografia. Como explicado nas convenções no início desse trabalho, foram alterados as expressões da escrita para os padrões atuais.

${ }^{74}$ Em excelente pesquisa de alguns temas pouco abordados sobre os primeiros anos da República no Brasil está no livro do estadunidense Steven C. Topik (2009, p.125), para esse autor, com o qual concordo, a substituição da Monarquia foi feita de maneira autoritária: "Jamais uma revolução de tal magnitude foi realizada com tão pouco entusiasmo', ironizou a 'Economist' londrina quando militares no campo de Santana, no Rio de Janeiro, derrubaram o regime imperial. A revolução, cujos defensores mais radicais compararam à Revolução Francesa, foi na realidade um golpe de Estado." (TOPIK, 2009, p.125). (destaques meus) Em uma carta de fevereiro 1890 para sua família na Alemanha, Emil Odebrecht (1835-1912) responsável por levantamentos na área de litígio ainda no Império, como abordo mais em frente, denominou a criação da República no Brasil de ditadura militar: "Não podemos esperar muita coisa boa da nossa ditadura militar (Militärdiktatur), que não larga da mão o comando e está convencida de poder tratar o povo como uma horda de carneiros!". (ODEBRECHT, 2006, p.423).
} 
rarefeita participação popular na implementação da nova ordem política seja porque, não havia dado tempo para ter entrado "no hábito" da desigual cultura política brasileira de então. ${ }^{75}$

O neófito sistema republicano passou a interferir diretamente nas interpretações de alguns fatos envolvidos diretamente ao território do País. Republicanos tentaram (e)levar ao máximo da esfera de visibilidade, algumas atribuições de nacionalidade pelo território. Atores sociais com destaque aos militares membros do exército, sustentadores e idealistas da recente República, buscaram chancelar as representações de conquista e segurança territorial como (e)feito $s e u$, resultado de um momento de superação monárquica. O território como um dos apoios para literalmente fazer institucionalizar a República, "Enfim, foi nesse período de transição da Monarquia para a República (e do trabalho escravo para o trabalho livre) que a visão da identidade pelo espaço parece adquirir certo relevo na representação simbólica do Brasil.” (MORAES, 1991, p.170).

Não se vivia propriamente em tempos de paz. As formas de tratar a informação vinda dos Estados Unidos, pode ser vista como um uso para ajudar a difundir tanto uma coesão interna - num espírito de pertença e orgulho do País recém "trocado" de comando - como também, um calmante aos exaltados ânimos, particularmente pela ainda presente Revolta Federalista ${ }^{76}$ (ocorrida de fevereiro 1893 até agosto de 1895).

O já citado impresso “A República” (que lembrava ser um Jornal da manhã) dizia: “[...] foram anteontem, iluminados todos os edifícios das repartições federais e estaduais". (A REPUBLICA, 10/II/1895, p.01). O mesmo jornal havia publicado no dia anterior - 09 de fevereiro - as trocas de telegramas entre várias partes do Brasil em tom bastante comemorativo. O comandante do $5^{\circ}$ Distrito localizado em Curitiba, por exemplo, general Santos Dias, telegrafou a cidade a essa altura já com o novo nome:

\footnotetext{
${ }^{75} \mathrm{O}$ forte tom da expressão a seguir de José M. de Carvalho (2013, p.27) embora, contundente, reflete sim, o baixo grau de identificação (ou de participação) política da população, com suas instâncias/instituições de decisões e poderes estatais (destaques meus): "Tratava-se de uma República sem povo". (CARVALHO, 2013, p.27). Parte do presente capítulo dialoga com obras desse autor, particularmente o livro "Formação das Almas. O imaginário da República no Brasil." (CARVALHO, 1990).

${ }^{76}$ Criativas pesquisas de Luís C. Villafañe G. Santos (2012; 2010), torna suas publicações leitura necessária para quem discute esse período, principalmente o Barão do Rio Branco e a política externa brasileira: "O laudo do presidente Cleveland concedendo ao Brasil a posse sobre todo o território em questão foi conhecido em fevereiro de 1895, já no governo de Prudente de Moraes, e transformou imediatamente Rio Branco em uma celebridade no Brasil. Ainda em estado de guerra civil, pois a Revolução Federalista só seria encerrada em agosto daquele ano, a vitória na questão dos limites com a Argentina era um fato que unia todos os brasileiros." (SANTOS, 2012, p.83-84). (destaques meus)
} 
Florianópolis ${ }^{77}$ (substituindo a então chamada, Desterro) dizeres destinado ao coronel Moreira César, "Mandei iluminar edifícios militares e mais festas, músicas, etc." Encerrava o telegrama, segundo saiu publicado: "Aperto de mão" (A REPUBLICA, 09/II/1895, p.02). Ao coronel em Palmas, impresso no jornal, o general termina o telégrafo com um comemorativo rugido: "Brasil vitorioso questão Missões arbitragem. Norte América decidiu favorável nossa cara Pátria. Urrah!”. (A REPUBLICA, 09/II/1895).

Imagem 4: Área total do Litígio, $30.621 \mathrm{~km}^{2}$ segundo: Ferrari (2010, p.63); Doratioto (2012, p.41)

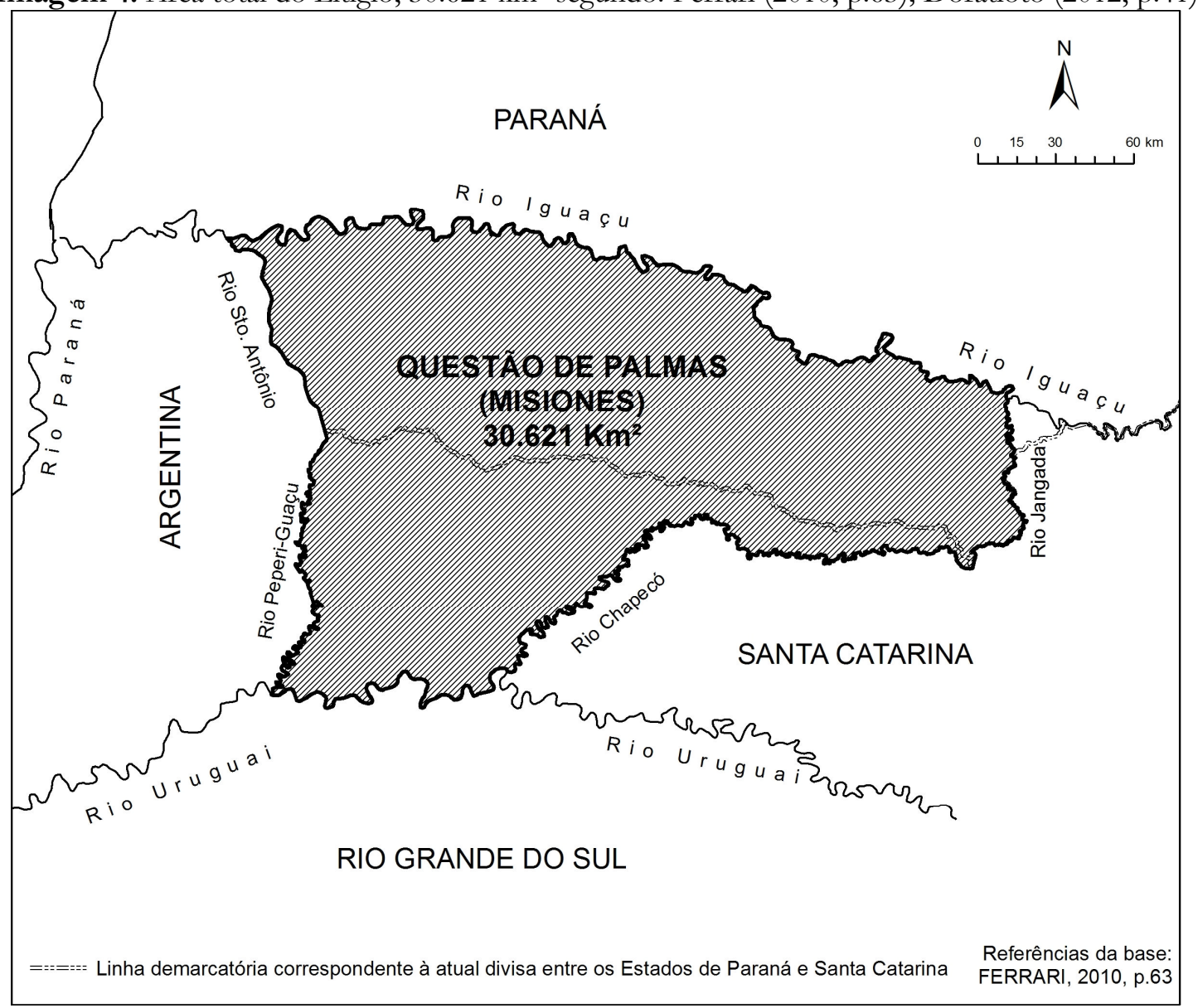

Ref. (FERRARI, 2010, p.63) Imagem 4, área total compreendida do litígio

Motivados para comemorar, segundo descrevia tal jornal republicano de Curitiba, um quartel general chamava atenção pelas músicas, por queimar muitos foguetes e "Na madrugada, bandas de clarins percorreram as ruas tocando alvorada." (A REPUBLICA, 09/II/1895, p.01). Afinal, saíra o voto da decisão a quem iria pertencer as terras que estavam na arbitragem do presidente estadunidense: a área de Palmas

\footnotetext{
77 “A Revolução Federalista tinha se estendido desde o Rio Grande do Sul aos três estados do sul do país, tendo sido ocupada Curitiba em janeiro de 1894. [...] em maio, o Paraná foi recuperado pelas tropas legalistas que, em abril, ocuparam a capital dos revoltosos, Desterro. Essa cidade posteriormente foi rebatidaza como Florianópolis em homenagem ao marechal." (SANTOS, 2012, p.62).
} 
disputada pela Argentina com o Brasil era confirmadamente, brasileira. Alguns políticos, militares, funcionários de Estado e aqueles que exerciam algum poder de mando, governo ou influência política, pareciam mais do que festejar, desejavam "republicanizar"78 a decisão do árbitro, passada a ser lida como sendo em "nosso" favor.

As positivadas publicações em jornais, anteriormente citadas, não se tratavam de simples opiniões desprovidas de intencionalidades. Faziam mostrar palavras transmitidas por telégrafos como se notícias fossem e, com significados de realização coletiva. Algumas daquelas publicações tratavam de buscar ampliar visibilidade dos políticos de então, escrevendo como se realizasse mais do que uma chancela definitiva, uma incorporação de área; na promoção do se sentir nacional, porque havido se não a expansão, pelo menos a manutenção de espaço. A forma de elevar o território como um dos entes sagrados da nacionalidade brasileira, se renovava e reproduzia; ${ }^{79}$ em parte, resultado da influência e "herança colonial" atrelado e relacionando ideia de pujança e dádiva, com proporção de domínio de espacialidade. ${ }^{80}$

Fizeram daquele momento uma comemoração nacional e, do resultado buscaram de variadas formas capitalizar em nome do sistema político recente; como dessa opinião dirigida do jornal paranaense, o qual destaco: “[...] só com a República podia ser resolvida tão longa questão.” (A REPUBLICA, 09/II/1895, p.01). A garantia do domínio de um espaço e o consequente reconhecimento do limite da fronteira argentinobrasileira foi utilizado como estratégia discursiva, para afastar a Monarquia ou para

\footnotetext{
${ }^{78}$ Evidentemente há diferentes maneiras de entender a expressão "republicanizar". Luís C. Villafañe G. Santos (2012, p.57) a utiliza sobre a estratégia de aproximação brasileira de países americanos, particularmente dos EUA. Não se trata de noção neutra mas sim, polissêmica: "[...] a republicanização da política externa se traduziu em um anseio de americanização, executada de forma atabalhoada. Havia uma desconfiança contra as potências europeias, cujo ímpeto imperialista alcançava seu zênite. Existia, por outro lado, um sentimento de identificação com os Estados Unidos. A modernização era vista por muitos como a americanização do Brasil e prosperava em sentimentos favorável ao estreitamento dos laços com a potência do norte. Esse desejo encontrava eco nos Estados Unidos, que nas décadas de 1880 e 1890 estavam vivendo um momento de redefinição de sua inserção internacional.” (SANTOS, 2012, p.57)

${ }^{79}$ Há quem pense diferente, mas discordo, parcialmente, dessa afirmação “[...] a ideia de que o Brasil se confunde com o Estado brasileiro.” (RICUPERO, 2000, p.13). Entretanto, para esse mesmo o autor: "Delimitar o território é o primeiro ato de inserção do país no mundo.” (RICUPERO, 2000, p.06)

80 “"...] a colonização é em si mesma um processo de relação entre a sociedade e o espaço. A colonização envolve uma sociedade que se expande e os espaços onde se realiza tal expansão, implicando apropriação da terra e submissão das populações autóctones. A colônia representa também a consolidação dessa domínio, sendo assim o resultado da conquista territorial." (MORAES, 2006, p.09). "E a história brasileira é exemplar nesse sentido, na medida em que todos os condicionantes da conquista espacial mantêm-se ativos num país marcado pelo domínio de vastos fundos territoriais." (MORAES, 2006, p.09).
} 
substituindo representações ligadas à coroa, acoplar ideários republicanos no imaginário da nacionalidade. Como disse Francisco Doratioto (2012, p.34), desse contexto em que "o Estado, tomado pelo pensamento positivista, desconstruía os heróis da Monarquia." A invenção da República buscava constituir-se e construir-se; o imaginário de conquista e invulnerabilidade do território também fora utilizado para tanto. Eventos tratados como causadores de comoção nacional eram bem-vindos, porque dependendo da forma como seriam interpretados, poderiam ajudar a instaurar símbolos para a República. ${ }^{81}$

Imagem 5: Colônias Militares e áreas pretendidas pela Argentina até 1888 e após

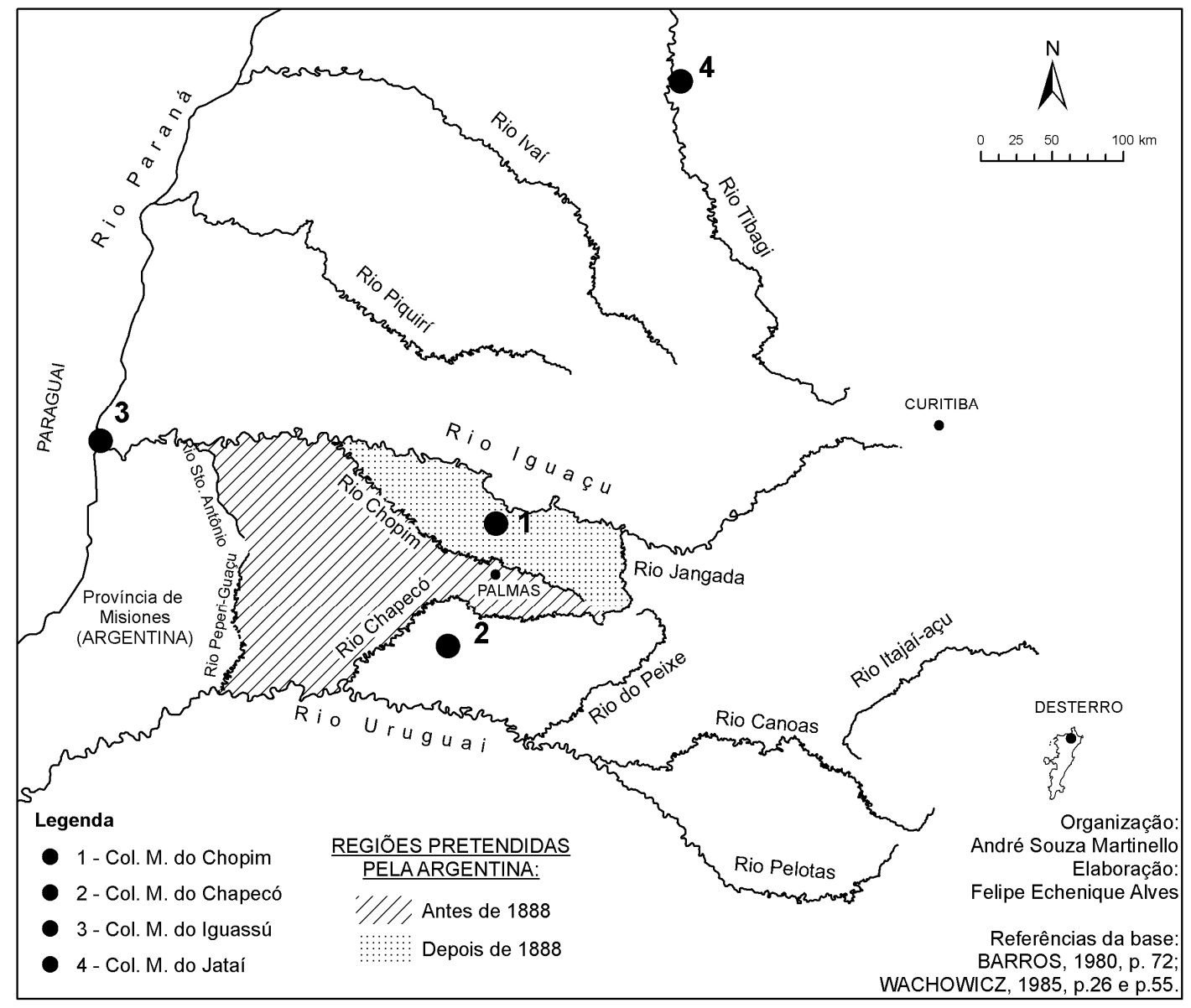

O Império brasileiro fundou colônias militares fora do litigio até 1888, quando Argentina passa a reivindicar área maior do que havia feito até então. Observar localização das colônias ños 1, 2 e 3.

Noticiavam-se comemorações, afinal, a "quantidade" de espaço - retratado como se fosse algo - de todos brasileiros, não fora desmembrada nem diminuída. Ao que dizia o jornal paranaense, viera telegrama do governo federal destinado ao comandante militar dali de Curitiba, para mandar tocar bandas militares de música e

\footnotetext{
81 "A busca de uma identidade coletiva para o país, de uma base para a construção da nação, seria tarefa que iria perseguir a geração intelectual da Primeira República (1889-1930). Tratava-se, na realidade de uma busca das bases para a redefinição da República [...]." (CARVALHO, 1990, p.32-33).
} 
iluminar a frente dos edifícios. Também naqueles telegramas que os jornais diziam reproduzir, se percebe as maneiras diferentes com que o general do $5^{\circ}$ distrito sede na capital paranaense se reportava às diferentes hierarquias - ao menos, assim saiu impresso nos jornais - Somente em telegrama dirigido a um coronel na capital do País terminava com a saudação ${ }^{82}$ realizada pelos ideólogos e partidários do regime republicano: "Saúde e Fraternidade". Aos telegramas para "a periferia" não aparece ter se desejado saúde, nem fraternidade; nesse mesmo (tendo sido o único) dos telegramas colocados nas páginas do jornal, em que foi feita menção a área resultado da arbitragem vir a ser futuramente, uma nova unidade federativa do País.

Uma certa tímida noção dessa área ter alguma independência, fazendo parte do Brasil dentro de uma esfera de autonomia como as demais províncias, também já havia aparecido indiretamente, três anos antes da arbitragem. Em 1892, um oficial da marinha e diplomata (Henrique C. R. Lisboa), alertava - ou defendia o posicionamento - como não aceitável realizar votação, a quem as pessoas de Palmas desejariam pertencer. Tal escuta, de opinião de moradores do espaço em litígio poderia (segundo autor de texto disponível no acervo da biblioteca do Arquivo do Itamaraty no Rio de Janeiro), gerar uma espécie de argumento com uso para outra nação (a Argentina, propriamente).

[...] o território de Missões entraria a formar parte tão integrante da União brasileira como qualquer dos estados federais: a vontade de trocar nacionalidade manifesta pelos habitantes desse território seria um ato de rebelião que nenhuma nação vizinha poderia apoiar ou provocar, por mais que o resultado do plebiscito pudesse ser-lhe favorável. (LISBOA, 1892, p.36).

Para àquela "ex-área em litígio" passasse a ser um novo Estado deveria se tornar independente ou, emancipada de partes das províncias do Paraná e de Santa Catarina. Chamo atenção (na citação a seguir em destaque) para o fato de ser mencionada, pelo General em Curitiba, a ideia de uma nova futura unidade federativa. Mas só fez essa menção quando se reportou ao Rio de Janeiro e não aos demais telegramas ao interior mais próximo do palco que definitivamente "abrasileirava-se", por decisão final do jure dos EUA: "Viva Brasil Republica! Viva futuro Estado Missões! Saúde e Fraternidade" (A REPUBLICA, 09/II/1895, p.02).

\footnotetext{
${ }^{82}$ No Brasil “[...] o tratamento por cidadão foi adotado - cidadão presidente, cidadão ministro, cidadão general -, substituindo o solene, imperial e católico "Deus guarde Vossa Excelência" da correspondência oficial; foi introduzido o Saúde e Fraternidade." (CARVALHO, 1990, p.13) (destaques meus)
} 
Misiones era o nome atribuído à área ${ }^{83}$ por argentinos. $\mathrm{O}$ autor do laudo brasileiro na questão, Barão do Rio Branco, recusava tal uso em preferência de outro topônimo, o de: Palmas; o que exemplifica a denominação e a nomenclatura de algo ou lugar como uma "luta das classificações", feliz expressão de Pierre Bourdieu (1989, p.115) sobre a disputa e os conflitos pelo poder de dar (ou atribuir) nomes.

Nomear está envolvido em disputas nas sociedades (ou é parte das relações sociais e de poder), às vezes, por uma busca menos do nome em si e mais da expressão de autoridade por ter nomeado; dos créditos resultado da nomeação. Se Rio Branco argumentava não ter havido a fundação ou presença de nenhum daqueles redutos das missões dos Jesuítas, não justificando para o brasileiro, a mesma expressão de nomeação realizada pelos argentinos; sua disputa estava mais pelo poder de nomear do que pelo nome. ${ }^{84}$ E claro, para delimitar a diferença: “A fronteira, esse produto de um acto jurídico de delimitação, produz a diferença cultural do mesmo modo que é produto desta." (BOURDIEU, 1989, p.115). Na correspondência entre republicanos e militares republicanos frequentemente ocorria à presença da expressão Missões e nem sempre, Palmas. Às vezes, alternavam entre uso das duas, parecendo não demonstrar grande preocupação entre os militares da relação entre nome e a legitimidade da posse, questão, aliás, dedicada aos estudos do Barão do Rio Branco. Mas voltemos, no parágrafo a seguir, a ideia de um novo Estado (da União) na área que passara por litígio. Ideia manifestada seletivamente e não presente em todos os telegramas.

Se, para o telegrama à capital do País foi usada uma palavra, com sentido de que na área da vitória do litígio haveria possibilidade de criar-se um novo Estado, no mesmo jornal aparece o telegrama enviado - assinado pela mesma autoridade - para região de fronteira, Xanxerê, agora com uma sutil diferença. Muito próximo da influência da área de decisão desse litígio, o telegrama para um capitão, como saiu no jornal, faz menção

\footnotetext{
${ }^{83}$ Se do lado brasileiro partes das terras estavam sob jurisdição de Santa Catarina e Paraná, na Argentina a unidade federativa que fazia divisa, denominada de Província de Misiones. "[...] (o Barão não gostava da última denominação [Misinoes] pois entendia que o território nunca tinha feito parte da província jesuítica de Misiones)." (RICUPERO, 2000, p.24).

${ }^{84}$ No capítulo IX, do Tratado da Questão de Limites entre o Brasil e a Argentina, o Barão do Rio Branco (2012 [1 ${ }^{a}$ ed: 1894], p.211) inicia defendendo a não aplicação da expressão "Missões" para o lado brasileiro: “[...] Misinoes - designação que alguns escritores brasileiros têm adotado nestes últimos tempos. Do ponto de vista argentino, ela é bem aplicada porque o litígio versa sobre qual deve ser o limite oriental do território argentino de Misiones; mas do ponto de vista brasileiro, e considerando-se a história geográfica da América do Sul, essa designação é imprópria e inexata, porque o território brasileiro que a República Argentina deseja adquirir com a substituição do Pepiri-Guaçu e Santo Antônio do Tratado de 1777 pelos dois rios mais ocidentais, inventados em 1788 e 1791, nunca fez parte da antiga província de Missões da Companhia de Jesus no Paraguai, depois chamada pelos espanhóis - província de Misiones." (RIO BRANCO, 2012 [1 ${ }^{\mathrm{a} e d:}$ 1894], p.211). (destaques meus).
} 
ao pertencimento nacional e não à emancipação da área e, nem encerrava com a saudação típica dos primeiros anos republicanos, mas dava vivas à República. ${ }^{85}$

A quem estivesse mais próximo da região de Palmas o quesito apontado como importante a se dizer e lembrar em telégrafo parece ter sido: ali também se tratava de ser, antes de tudo, Brasil. Recortando esse aparente detalhe, quero estranhar como naqueles anos do início da República, parece não se dar ao direito ou ao menos, não estimular autoridade local e, de uma região a vir a ser (uma nova) "unidade federada" do País, nem a desejar que repercuta ideia de um nova Província. Ao menos - é o que parece - pelas comunicações realizados pelos centros de decisões, nesse caso capital do Paraná com a capital do País, mencionou-se possibilidade de novo Estado ser criado. Mas não ocorreu menção quando se remeteu telégrafo à região que congregaria (ou resultaria) nesse possível e, futuro, novo Estado.

Contudo, se chamei essa atenção não apenas para apontar diferenças de trato ou das relações de forças a permitirem instituir qual destino da circunscrição aparentemente - conformadora de hierarquias espaciais, como resultados de poderes entre centralidades e fronteiras periféricas, mas trouxe esse tema para esse texto, porque mais tarde em conseqüências e após instituição do Território Federal do Iguaçu (no ano de 1943, como discutirei no $4^{\mathrm{a}}$ capitulo), vai emergir um certo regionalismo que buscará no resultado da arbitragem dos EUA em 1895, um dos momentos fundadores (ou ídolo da "origem" e congregação da unidade) da região. Essa é também uma das referências mais antigas que encontrei sobre a criação de outro Estado, a ser desmembrado de área do Paraná e Santa Catarina. Aliás, alguém dirá como aquele sonhado Estado das Missões chegou a ocorrer, com o nome de Iguaçu, o território federal (entre 1943-1946).

As difusões de telegramas em jornais e seus dizeres tratados como novidades a serem retransmitidas, publicadas, comemoradas e divulgadas fazem parte de busca de legitimação do que José M de Carvalho (1990, p.10) denominou como "extravasamento das visões da república para o mundo extra-elite, ou as tentativas de operar tal extravasamento". No livro A formação das almas, o imaginário republicano no Brasil, Carvalho (1990) se ocupou de compreender muitas tentativas e esforços de (auto)legitimação para justificar (e naturalizar a derrubada da monarquia e) instauração republicana. Como ele mesmo entende: "O povo estava fora do roteiro da proclamação,

\footnotetext{
85 “[Ao] Capitão Menezes - Xanxerê 7 [fev.] - Decisão arbitragem governo Norte-Americano favorável nossa querida Pátria. Viva a Republica brasileira! Vivam as Missões brasileiras! General Santos Dias.” (A REPUBLICA, 09/II/1896. p.02)
} 
fosse este militar ou civil [...]." (CARVALHO, 1990, p.52). O caso brasileiro é: retirada ou substituição da Monarquia por uma República, sem uso de apoio ou opinião do povo.

Esse autor tratou das disputas simbólicas, ideológicas, portanto, principalmente, políticas, na verdadeira batalha - que, ainda segundo o próprio Carvalho (1990, p.12), chegou a durar quase um século - para assegurar uma mudança do imaginário nacionalista marcado pela família Imperial, mais particularmente na figura de Pedro II e Isabel, domesticando (novos) símbolos, agora após 15 de novembro de 1889, para esfera de valores republicanos. É pertinente ressaltar como os últimos meses da Monarquia haviam sido um dos seus áureos momentos de maior prestígio popular, principalmente pelo fim da escravidão decretada no ano anterior, em 13 de maio de 1888, “[...] caso tivesse sido tentada qualquer revolução do tipo pretendido, o povo que em Paris saiu às ruas para tomar a Bastilha e guilhotinar reis não teria aparecido. As simpatias das classes perigosas do Rio de Janeiro estavam mais voltadas à Monarquia." (CARVALHO, 1990, p.26).

As interpretações desse momento feitas por Steven C. Topik (2009) são muito semelhantes às de - se não, inspiradas em - José Murilo de Carvalho (1990); ambos lembram como a família real e os políticos monarquistas não haviam se planejado quanto à maior sustentação monárquica, "O Império foi derrubado mais por falta de respaldo do que por verdadeira oposição.” (TOPIK, 2009, p.125).

Não é à toa que para a República "pegar" ou como dizemos ainda hoje, cair no gosto popular, seus promotores passaram a manejar símbolos e discursos buscando atingir várias esferas, em particular: as camadas sociais mais simples, como os libertos. “[...] o novo regime receberia pouco apoio doméstico. Afinal de contas, o Império caíra precisamente no momento em que desfrutava de próspera economia e da intensa popularidade interna gerada pela abolição da escravatura.” (TOPIK, 2009, p.124).

Do ponto de vista de representações geográficas, considero a tese de José Murilo de Carvalho (1990) reafirmada como válida e pertinente. A partir de documentos da época, pode-se notar a mobilização de aspectos, "conceitos" e ideologias geográficas (MORAES, 2005) que mediadas por diferentes formas de discursos, passaram a ser utilizadas para buscar real identificação da nascente República. Foi o que tentei tratar até aqui nesse capítulo, algumas intencionalidades através de promoção de palavras e descrições de atos, acabando por atribuir sentidos ao resultado da arbitragem sobre limites entre Países e mais ainda, atribuindo sentidos sobre àquele espaço com o fim de 
uma disputa litigiosa. "A mudança da forma de governo recoloca o tema da unidade nacional e do ordenamento (ou reordenamento) do Estado." (MORAES, 1991, p.170).

Que a própria forma política, República e, sua instalação no Brasil possa ser interpretada como uma ideologia, não é lá um dissenso ou novidade. Chamo atenção para a possibilidade de tratar como parte das ideologias geográficas para e pela República o resultado da formalização do limite de fronteira com a Argentina, afinal, pode-se notar "[...] as representações do espaço como um dos materiais constitutivos da esfera do discurso político, um dos assuntos das constelações ideológicas." (MORAES, 2005, p.93). No livro Ideologias geográficas. Espaço, cultura e política no Brasil, Antonio Carlos R. Moraes (2005), buscou estimular a realização de pesquisas levando em conta papéis de imperativos territoriais no Brasil, relacionando, quando possível, com o tratamento das formas espaciais como produtos históricos. Com base nas discussões desse autor, tratei aqui de rastrear parte das políticas (ou fragmento de discursos) daquelas ideologias e seus contextos ou intencionalidades de formulação.

Como a produção social do espaço possui histórico e suas formas de construção variam ao longo do tempo, as concepções a respeito dos mesmos espaços também não são únicas, nem estanques e automáticas, estando envolvidas em relações de força e interesses. A mim, não é constrangedor assumir como as formas de tratar ou conceber os espaços não são prontas, auto-explicativas ou dadas a priori: "Dizer que a produção do espaço social é um processo teleológico significa que ele envolve uma finalidade." (MORAES, 2005, p.15). Aqui se crítica àquelas noções de espaço como se existissem arraigadas nele mesmo, o acompanhassem previamente de maneira encrustada como uma essência (natural), pronta, evidente, universal, acabada e próprio para macronarrativas. Ao contrário de uma espaciologia ${ }^{86}$ estou de acordo em perceber como nos anos iniciais do novo regime, as divergências ("internas") entre os republicanos alterou completamente o sentido atribuído ao mesmo litígio; utilizando de concepções dispares de um mesmo espaço.

Embora afirmativa evidente, vale dizer: mesmo inserida "dentro do território do Brasil”, o espaço da área de Palmas não é predeterminado brasileiro por natureza, mas por promoções de acordos, reconhecimentos e principalmente, convenções. Não foi por pretensa força intrínseca espacial tornado brasileiro, mas por construções sociais

\footnotetext{
${ }^{86}$ Significa assumir estar de acordo com algumas ideias do clássico e polêmico artigo de Marcelo J. L. de Souza (1988), quando o autor diz (destaques meus): "[...] Espaço e Sociedade não podem ser vistos como dois elementos autônomos de um conjunto, [nem] dois entes separáveis." (SOUZA, 1988, p.26).
} 
perceptíveis temporalmente. A tentativa de evitar o nome argentino (Misiones) para a área, como fazia Barão do Rio Branco, é um claro exemplo dessa invenção de sentido.

Apontar alguns interesses e destinos propostos à área em disputa com Argentina será forma de responder à questão (Territórios ambíguos, interesses republicanos?), com a qual iniciei esse capítulo, considerando influencias mobilizadas dentro dos jogos de forças, resultantes das relações de poder que em última análise se espacializam (RAFFESTIN, 1993). E como respondo essa questão do presente capítulo: entendo a mobilização de discursos opostos, como estratégias pelo interesse de legitimidade republicana (não em si do interesse público no sentido da "coisa pública", res publica), na vontade de imposição da forma política "não-monárquica" ou pós monarquia.

Em dezembro de 1891 Quintino Bocaiúva assina um artigo, em tom de defensiva, intitulado apenas: "Questões Missões”, publicado em Jornal da capital, $O$ Prava, disponível no Arquivo do Itamaraty (na cidade do Rio de Janeiro). Nele, o primeiro chanceler republicano brasileiro já fora desse ministério quando publicado tal texto (deixou o cargo em fevereiro de 1891), afirma ter sido procurado pelo ministro das Relações Exteriores da Argentina "poucos dias depois de proclamada a República". Escreve Bocaiúva ter dito àquele ministro sobre a tão longa competição pela área:

Respondi a sua excelência [ao ministro argentino] que o momento não me parecia o mais oportuno para tratar de grave e debatido assunto, mas que no meu caráter de membro do governo provisório encarregado do ministério das relações exteriores da República não podia recusar-me oficialmente a aceitar qualquer gestão diplomática. (BOCAIUVA, 15/XII/1891, p.01).

Diz Bocaiúva ser sua obrigação receber oficialmente esse, ou qualquer outro "representante de potencia estrangeira e amigos." E parece se posicionar de maneira mais clara sobre qual sua concepção da República brasileira, particularmente em relação aos Países vizinhos, pois, diz, não perceber como algo estranho as relações com a Argentina nem em seus sentimentos pessoais e, nem do governo provisório. Ainda mais, comemorava Bocaiúva, porque o Brasil acabava de ingressar na família das Repúblicas americanas. O tema do litígio, disse Bocaiúva ter informado ao outro chanceler, seria estudado e resolvido em conselho de gabinete, e solicitou comunicação escrita sobre o tema, que ele mesmo, Bocaiúva, levaria "ao conhecimento dos meus colegas." (BOCAIUVA, 15/XII/1891, p.01).

No relatório anual apresentado ao chefe do Governo - que então se chamava de - Provisório em 1891, Bocaiúva também não incluiu nenhuma informação sobre o acordo entre Argentina e Brasil, pois argumentava necessidade de sigilo até quando o 
mesmo fosse decidido pelo Parlamento. "Tendo ambos os governos convencionado não dar-lhe publicidade", escreve o ministro das Relações Exterior do Brasil "antes de ser oportunamente apresentado aos parlamentares de um e de outro país, de cuja aprovação dependem, deixo de inseri-lo neste Relatório, aguardando a deliberação do Congresso Nacional”. (BOCAIUVA, Relatório, 1891, p.35).

A posição de alguns republicanos da geração de Bocaiúva era de que o Império brasileiro tinha sido demasiadamente distante dos Países vizinhos. Chamo atenção ao simbólico das comunicações, o nomear e aos atos de inspiração da Revolução Francesa. Nessa documentação dos anos iniciais do chamado governo "provisório" (da República), quando o ministro das Relações Exteriores da Argentina, Enrique Moreno ${ }^{87}$ inicia o tal memorando - solicitado por Bocaiúva - chama-o de cidadão.

Já mencionei aqui como expressões pensadas como próprias da Revolução Francesa foram mobilizadas pelos republicanos e, aplicadas no contexto do pós derrubada da Monarquia. Fizeram isso, tanto por dizerem acreditar no fim do Império como uma reprodução da "Queda da Bastilha" cem anos depois da França, mas também por entenderem o 15 de novembro de 1889 como uma revolução. Entretanto, as nomenclaturas importadas da França não parecem ter sido usadas tão amplamente ou genericamente assim, muito menos coerentemente com o contexto de onde diziam se inspirar. Ironia maior ainda dessa complexa trama de contrariedades, se dá quando a França reclama ao Brasil, a morte de franceses no contexto da Revolução Federalista. ${ }^{88}$

E nem todos ministérios ou setores do Estado parecem ter estimulado a usar as tais saudações de inspiração francesa. A Proclamação da República partindo de dentro do Exército não congregou tão completamente a Marinha, como se pode perceber nessa informação do jornal Diário do Comércio de Curitiba de março de 1891, quando informou em sua segunda página, "a fórmula saúde e fraternidade foi suprimida das

\footnotetext{
${ }^{87}$ Esse ministro já havia tentando tal pedido de partilha da área ainda no Império, em comunicação secreta: "Repetindo proposta de Argentina feita em 1885, o representante desse país no Rio de Janeiro, Enrique B. Moreno, propôs confidencialmente, em fevereiro de 1889, que o território litigioso fosse dividido entre os dois países. O Conselho de Estado analisou e recusou com unanimidade a proposta, sugerindo que a questão fosse levada a arbitramento." (DORATIOTO, 2012, p.43).

${ }^{88}$ Como aparece em maio de 1895, no relatório anual do ministro - na época Carlos Augusto de Carvalho - das Relações Exteriores ao Presidente da República sobre o ano anterior, "República Francesa. Reclamação pelo desaparecimento dos engenheiros Buette, Müller e Etienne, foram segundo se diz, fuzilados em Santa Catarina, por ordem do coronel Moreira Cezar, governador desse Estado, e o Dr. Déville, também, segundo se diz, foi degolado no Rio Grande do Sul, quando fugiu depois da batalha de Sarandy." (CARVALHO, Maio de 1895, p.07)
} 
comunicações oficiais dos ministérios da marinha e agricultura." (DIARIO DO COMÉRCIO, 30/III/1891, p.02).

Ao que parece, nem só por decreto entrou no hábito as saudações inspiradas na Revolução Francesa e, também nem só por estar ou não instituída tais saudações que foi ou deixou de ser realizada. Barão do Rio Branco foi um dos que não abriu mão do título nobiliárquico, como um claro sinal de não desistir, completamente, de suas convicções monárquicas. "Continuava a assinar seu nome utilizando a palavra 'barão', apesar da proibição do governo provisório do uso de todos os títulos nobiliárquicos, e os ofícios que enviava já de Washington terminava sem a nova fórmula oficial: 'Saúde $e$ Fraternidade'." (DORATIOTO, 2012, p.48).

Um jornal da época aqui tratada - os anos por volta do resultado do final do litígio, início de 1895 - noticiou como uma corporação de barbeiros da capital de Santa Catarina quando solicitou direito de não trabalhar aos domingos após as 10 horas da manhã, assim denominou a uma autoridade, segundo publicado (destaco): "Nós, abaixo assinados, oficiais de barbeiro, pedimos ao cidadão presidente da intendência, para criar uma lei obrigando, aos domingos, o fechamento das barbearias desta capital, das 10 horas da manhã em diante. Esperamos ser atendidos." (A REPÚBLICA. 19/II/1895, s/ pág).

Mesmo ainda presentes àquelas expressões absorvidas como sendo da Revolução Francesa certo tempo depois da proclamação da República, mantinham a profunda hierarquia social brasileira. Como lembra José M. de Carvalho (1990, p.126), da readaptação feita e mediação de símbolos para a assimétrica sociedade do Brasil: "À igualdade jacobina do cidadão foi aqui logo adaptada às hierarquias locais: havia o cidadão, o cidadão-doutor e até mesmo o cidadão-doutor-general.” (CARVALHO, 1990).

Voltando a relação entre os ministros das relações exteriores da Argentina e do Brasil, mais particularmente na continuação do texto de Bocaiúva no jornal O Prava, quando ele afirmava transcrever a carta recebida do ministro argentino. Bocaiúva faz um uso desse memorando, de maneira a dar entender uma espécie de convencimento por parte do imperador brasileiro, como se esse tivesse aceito doar Palmas, dividindo irmãmente as terras, como aparecia no texto dito sendo de autoria do ministro argentino.

Bocaiúva resolve transcrever correspondência vinda da Argentina, mantendo-a em espanhol, publicada abaixo do seu artigo no jornal do Rio de Janeiro, e na descrição do texto do argentino aparecia como simpático ao imperador o posicionamento de fragmentar Palmas entre os dois Países. É como se Bocaiúva usasse do diplomata 
argentino para dizer estar cumprindo uma promessa feita antes da República. Monarquistas logo trataram de contatar o exilado imperador para desmentir Bocaiúva e demais republicanos que tivessem "colocado" palavras na boca do monarca, como afirmando a divisão (SANTOS, 2012). Jogar para o passado de antes do período republicado, como sendo o crédito original e início da ideia de dividir (fracionar, doar ou partilhar) área com a Argentina, tornou-se um discurso recorrente, mesmo certo tempo depois do voto vindo dos EUA colocar fim ao litígio.

Imagem 6: Linha imaginária demarcatória da divisão assina por Bocaiúva no Tratado de Montevidéu de 1890, segundo Ferrari (2010, p.67)

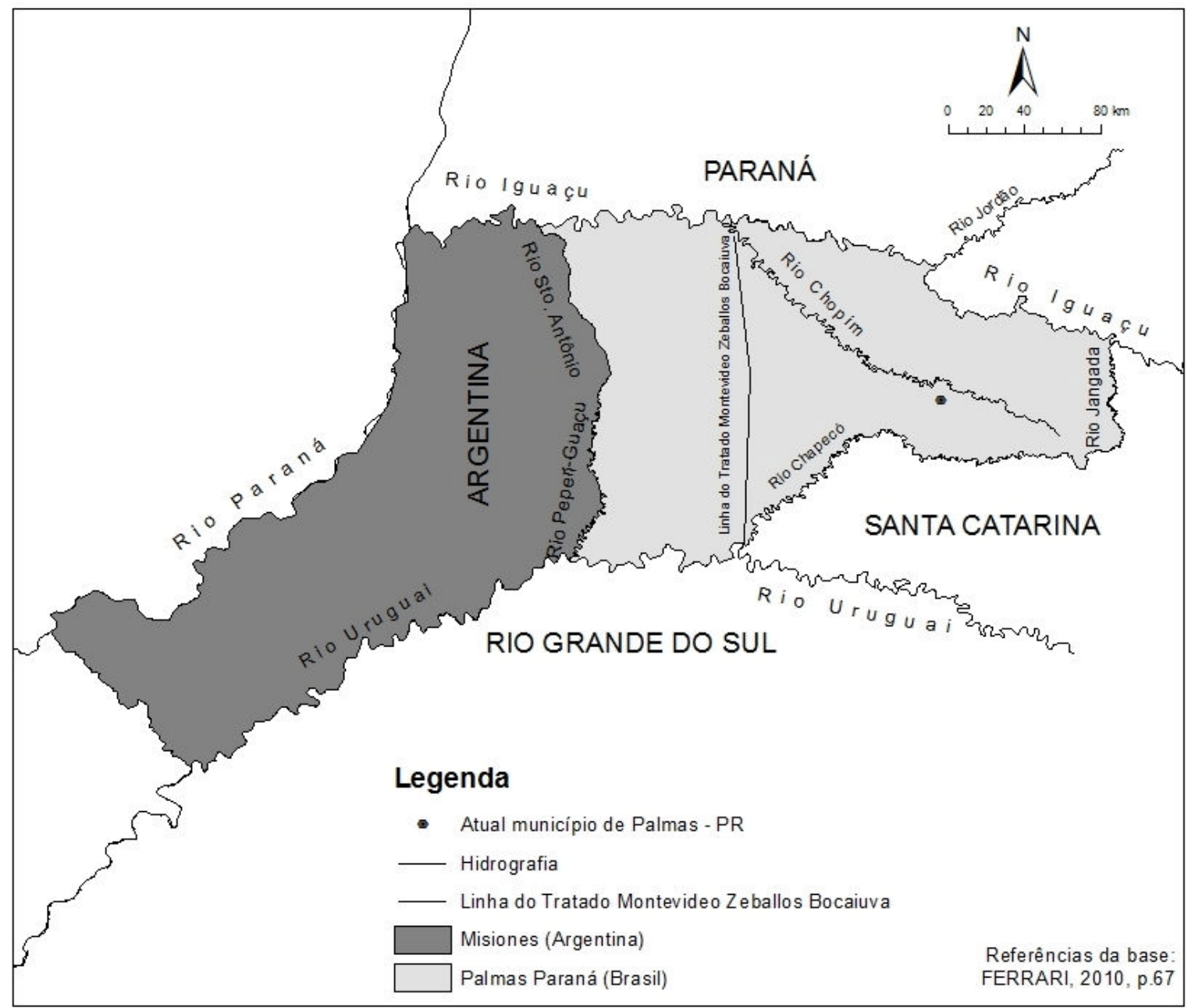

Em obra disponível no acervo da biblioteca do Arquivo do Itamaraty (no Rio de Janeiro), publicado por dois autores já no século XX, ano de 1901, ainda permaneceu a tentativa de difundir a ideia de divisão como vindo do Segundo Império. Segundo disseram Clovis Bevilaqua e Gregório T. Azevedo (1901, p.60): “Já nos últimos anos da monarquia, muitos estadistas se inclinavam para uma divisão do território litigioso". Argumentava-se da ideia da divisão ser legítima pelo resultado de paz trazido com ela. 
Entretanto, a ideia acompanhava de gritante contrariedade, pois ao contextualizarem a necessidade de paz, justamente um momento de muita tensão, desconfiança e mesmo conflito da instalação republicana, tal contexto não era o mesmo para o império desejar doar a área, mas sim a quem buscava - era o caso de republicanos - se legitimar na arena política. Por meio da divisão, dizia-se, "assegurávamos a paz que nos era sobretudo preciosa no momento da transformação política que se operava com surpresa e desconfiança das potencias europeias.” (BEVILAQUA; AZEVEDO, 1901, p.60).

Na geopolítica do Segundo Império, parecia ter se dado sinais mais beligerante do que passividades em perder terras. Jamais parece ter aceito sugestão de divisão, doação ou compartilhamento da área, partindo, inclusive, do Império brasileiro a proposta ao Congresso argentino, de ambos governos nomearem uma comissão mista de igual número de membros, para percorrerem a área; resultando em tratado de setembro de 1885. Como registrado no dossiê da defesa do Brasil entregue em 1894 ao governo estadunidense: “A Comissão Mista brasileiro-argentina começou os seus trabalhos em 1887 e terminou-os em 1890." (RIO BRANCO, 2012, p.525).

Foi recorrente em discursos de republicanos, dar um grande mérito de assinar o Tratado de Montevideo a Quintino Bocaiúva, mas uma dificuldade completa de assumir como algo também da República o projeto dessa partilha-doação. Entre outros motivos, talvez, pela expressão de inviolabilidade do território, como uma espécie de traição nacional. Doar a área para argentina pareceria - para o início da República, que era quem tinha a intenção - menos traumático se atribuído a ideia como sendo original à família real, exilada. Ou ao regime colocado em extinção, passado como antigo.

Chegou-se a interpretar como uma certa dor, a eventual perda dessa área, como fez o próprio Juca Paranhos no texto do processo de defesa do Brasil, dando um tom sentimentalista ao afirmar sobre a acordo assinado por Bocaiúva: "Na República Argentina esta solução foi festejada com grande entusiasmo. No Brasil, porém, ela produziu o mais profundo sentimento de dor e levantou unânimes e veementes protestos." (RIO BRANCO, 2012, p.254). Há quem tenha recorrido, mobilizando ideia de sentimentalidade brasileira para explicar o contexto da culpa da Câmara dos Deputados, não ter votado em favor da partilha com Argentina. Passou-se a culpar, como se argumentando, de uma incapacidade de compreensão (ou falta de frieza/racionalidade) política dos brasileiros, apaixonados. Sendo à passionalidade popular e sua consequente emotiva pressão, pois a assinatura do Tratado de Montevideo “despertou uma verdadeira tempestade de protestos patrióticos, uma condenação geral, 
pois que o povo não saber ter o cálculo frio do raciocínio que prevê os acontecimentos e procura afasta-los ou dirigi-los. Sua força é o sentimento [...]." (BEVILAQUA; AZEVEDO, 1901, p.60).

Pouco apareceu, entre republicanos, o assumir a autoria ou o projeto da ideia da doação de área presente no Tratado de Montevideo como algo seu (projeto daquela República inicial), mas aparece, paradoxalmente, positivando a liderança de Bocaiúva na assinatura desse mesmo Acordo de 1890. O tema dele (doação de área), seria algo ruim: coisa do Império; a assinatura da doação algo novo: coragem, coisa da República.

\section{Câmara/Congresso diz não a Bocaiúva, não à Argentina. Sim, ao Arbitramento}

Quintino Bocaiúva tentou utilizar estratégia discursiva persuasiva, na ideia de que a forma da decisão sobre a questão de Palmas viria renovada, superando às aparentes surradas discussões do Império, enfocando nas mudanças de quem decidiria sobre as relações exteriores do Brasil. O ministro Bocaiúva defendeu, quando ele se explicou ao Congresso Nacional brasileiro, colocando a Monarquia como ultrapassada. Segundo é possível ler em texto da época no Diário do Congresso Nacional, utilizandose de oratória com expressões parecendo tentar convencer da ideia de partilha, na sua arguição argumentou em favor da Câmara. Seguiu o discurso informando a existência de maior interação e poder do povo, via representante institucional, o Congresso.

Bocaiúva argumentou como após o fim do antigo regime, passou haver uma maior partilha do poder quanto às decisões das relações exteriores do País. Seguindo sua defesa, diferente da - em suas palavras - "índole do regime passado", quando o Império não tomava atitudes de escuta(r) aos políticos, que ali lhe ouviam " [...] desde os primeiros dias do Governo Provisório, em conselho de ministros do governo revolucionário, ficou ajustado que nenhum contrato desse gênero [internacional] se faria sem a cláusula da sua sujeição ao juízo e à deliberação dos representantes da nação." (BOCAIÚVA, 18/II/1891, p.475). Dizendo diferente de antes da República, alguns acordos e posicionamento das relações exteriores do País não eram mais - argumentava - decididos unilateralmente.

Republicanos, como Bocaiúva, fizeram claramente uma leitura ou, tentativa de difusão de como o Império leria - ao apontarem como poder autoritário, monodecisor às relações com a Argentina. Partidários do novo regime tentaram divulgar suas interpretações sobre a forma de resolver a questão, acompanhando de como os monarquistas entendiam o tema. Acusavam nas entrelinhas, por exemplo, da coroa ser 
menos disposta à divisão de poder, além de expressar "nacionalismo débil" ou de uma tal fraqueza política, que o faria perder área de Palmas. Passam a utilizar uma noção de boa gestão de território, como justificativa de um bom governo, de uma boa política. Recorrem as acusações ou a constatações do regime monárquico ser menos americano, ou do imperador desprezar tal área e poderia doar a mesma. Alguns republicanos, enfim, mobilizariam "possíveis" opiniões monarquistas, quase sempre como oposta do novo regime. Interessados como estavam em se estabelecerem e imporem sua interpretação como mais aceita possíveis, uma das maneiras de tratar o regime que os precedia, era apontando como territorialmente menos capazes de pro(mo)ver o Brasil.

Certa altura argumentou Quintino Bocaiúva, o acordo dividindo a área entre Argentina e Brasil era legítimo e havia sido assinado, pois, o governo provisório permitiria a decisão final ser tomada pelo Congresso. A maneira hábil de Bocaiúva negociar ou defender(-se) daquele acordo foi a de mobilizar a ideia de uma menor eqüidistância das relações entre os poderes. Buscou legitimidade para aprovação desse acordo, dizendo da chancela que a República dava ao Congresso. Mas não fora bem recebido Acordo de Montevidéu, nem por políticos, nem pela imprensa. O secretário do ministério das Relações Exteriores, Visconde de Cabo Frio, por exemplo, considerou necessário "afastar-se" da imagem como se apoiasse tal acordo; declarou-se contrário. Conhecedor da diplomacia brasileira e herdeiro de certa tradição monárquica, Cabo Frio que recebera título de Visconde em maio de 1889, fará um laudo e parecer bastante objetivo, sugerindo como o Brasil não precisava evitar arbitragem. Dizia não haver motivos da existência do acordo fechado no Uruguai, pelo primeiro ministro republicano das Relações Exteriores do País. Para Cabo Frio, o Brasil não tinha motivos para doar a área, nem o que temer quanto à garantia de legitimidade da posse.

A opinião do Visconde do Cabo Frio presente em uma correspondência guardada nos fundos do Arquivo do Itamaraty, data de junho de 1891. O conhecido secretário faz um arrazoado "técnico" de probabilidades e com possibilidades de como deveria comportar-se ou (re)posicionar o governo brasileiro, após o Congresso ter rejeitado o "Tratado de Montevidéu". Elencando possíveis situações, circunstâncias de estratégias geopolíticas com ganhos ou perdas, Cabo Frio entende o tratado como uma maneira da Argentina e Brasil evitarem diretamente um terceiro País como árbitro, pois a decisão do jure, presidente de outra nação, poderia fazer perder toda a área para um dos dois. Mas a suposição do acordo assinado em Montevidéu, alerta Cabo Frio, 
entendia condições favoráveis de domínio pelo governo argentino, "cumpre examinar se era suposição é fundada." (CABO FRIO, s/ data, mês VI de 1891).

Para o Visconde, às condições eram favoráveis ao Brasil, seja na comprovação dos respectivos nomes dos rios ou, seja como argumento de prévia posse, no sentido de "primeiro" domínio (aparecerá como forte recorrência para legitimar a área o principio jurídico do uti possidetis).

A posição do Visconde reflete uma discordância interna do ministério em relação ao papel do ministro Bocaiúva; Cabo Frio não concordava com a assinatura do Acordo de 1890 e acreditava como mais favorável a possibilidade de rejeitar o mesmo. Mesmo sendo a arbitragem uma alternativa não muito desejável para os interesses do Brasil para manter a área, também defendia não ser interessante abandonar ou desprezar o arbitramento, pois dizia, havia melhores provas em favor das terras serem brasileiras do que argentinas. Por outro lado, Visconde do Cabo Frio parece ter captado uma certa insegurança por parte da Argentina, segundo apontou, havia uma recorrente tentativa argentina de negociar simples e diretamente com o Brasil, tentando a resolução por divisão da área entre os dois, mesmo após a assinatura de intenção da arbitragem.

O Governo argentino sabe que o [rio] Santo Antonio-Guaçu não é contracovertente do Chapecó, porque o seu Ministro Senhor Moreno fez quatro tentativas para obter divisão do território, duas antes do tratado de arbitramento e duas depois: mas há de sustentar o contrário e não podemos impedir que assim fundamente o seu pretendido direito. Responderemos e cabalmente. (CABO FRIO, mês VI de 1891).

O documento assinado por Bocaiúva, no artigo $5^{\circ}$ do Tratado de Montevidéu dava uma relevante expectativa a respeito da confirmação desse acordo pelas casas legislativas dos dois países, pois assim previa: “[...] ratificações serão trocadas na cidade do Rio de Janeiro logo após a sua aprovação pela Assembléia Constituinte dos Estados Unidos do Brasil e do Congresso Argentino." (TRATADO DE LIMITES DE MONTEVIDEU, 25/I/1890). Parecia ter estado no horizonte de expectativas de quem assinou tal acordo, que o mesmo se realizaria; mas, dado poder ao Congresso brasileiro, chamado a opinar a casa do povo, não foi aprovado o Acordo de Montevidéu. Vetou-se em discussão de sessão secreta, o que se considerava "excessos de Bocaiúva". Luis C. Villafañe G. Santos (2012, p.52) explica bem todo esse contexto:

[...] Quintino Bocaiúva, foi nomeado ministro das Relações Exteriores do governo provisório, permanecendo de 15 de novembro de 1889 a 23 de janeiro de 1891. Como sinal dos novos tempos nas relações com os países americanos, ele assinou com o governo argentino, em 25 de janeiro de 1890, o Tratado de Montevidéu, pelo qual se abandonava o acordo alcançado pela diplomacia 
imperial para submeter à discussão da posse da região de Palmas a uma arbitragem pelo presidente dos Estados Unidos e procedia à divisão do território entre os dois países. O excesso americanista foi condenado na imprensa e no Parlamento, que rejeitou o acordo. Ao assumir seu mandato como presidente eleito pelo Congresso, Deodoro substituiu Bocaiúva por Justo Leite Chermont.

O Congresso brasileiro não aceitara perder nenhum pedaço da área, preferia ir ao árbitro, já combinado entre as partes; sendo os EUA. Acredito que o posicionamento do Visconde de Cabo Frio contrário a esse tratado, parece ter sido opinião ouvida entre membros do parlamente brasileiro. Mas, destacou-se principalmente, o relatório contrário à divisão elaborado pelo general Dionísio Cerqueira; a decisão foi passada às mãos do presidente estadunidense:

A Câmara dos Deputados brasileira, em sessões secretas realizadas nos dias 6 e 7 de agosto de 1891, escutou as explicações de Bocaiúva e no dia 10 desse mês aprovou parecer redigido pelo general Dionísio Cerqueira, contrário ao Tratado de Montevidéu e favorável ao recurso do arbitramento. (DORATIOTO, 2012,p.45)

Duas interpretações diferentes ocorrerem e foram alteradas nos quatro primeiros anos republicanos. O primeiro projeto republicano de destino a área de Palmas é o de que deveria ser doada, repartida ou fragmentada deixando integralmente ou parte para a Argentina, agindo assim, o Brasil simbolicamente atava-se, enfim, com afinidade aos Países vizinhos. Deixava-se de ser um País monárquico, se voltando à América, igualando-se como referência mútua em demais republicanos Países americanos. Nessa visão "ser republicano" seria partilhar da fraternidade americana e reduzir a imagem do Brasil, como único a ter sido longamente governado por um Imperador nas Américas. Com essa posição, Quintino Bocaiúva assinou um protocolo de intenções entre Brasil e Argentina de 1890 em Montevidéu (já mencionado Tratado de Montevidéu).

Mas, a versão promovida na prática foi ao contrário dessa, sendo a que discuti as repercussões aqui no início, qual seja sinteticamente: vangloriar a recusa de qualquer doação ou partilha das terras consideradas legítimas do Brasil e comemorar a arbitragem dos Estados Unidos como um ganho conquistado pela nascente República (mesmo sendo o arbitramento algo previsto no último acordo internacional da Monarquia brasileira com a Argentina, em 7 de setembro de 1889).

Esse segundo projeto (após derrota na Câmara e fim do arbitramento dos EUA) - a posição vencedora - tratou-se de dizer como uma vitória da República e, aparentemente, "denunciar" como monarquistas àqueles que haviam planejado "perder" 
tais fundos territoriais. ${ }^{89}$ Nesse caso, ser republicano passou a ser (significou) proteger território, incorporá-lo em um discurso nacionalista, usando-o do imaginário do espaço e da materialidade do mesmo como legitimador da própria intervenção dos militares, que puseram fim ao "regime anterior". Essa linha de raciocínio dos usos e sentidos do território, interpretações que tenho problematizado aqui, ajudaram a dar sentidos à região e principalmente, da vitória da arbitragem em prol do Brasil, um sentimento nacionalista. Na circunstância da República tentar ampliar e popularizar sua legitimidade, o resultado da arbitragem vinda dos EUA chegou em boa hora, mesmo que inversa da posição dos primeiros republicanos que haviam assumido chefia do Estado e alguns deles já haviam até saído do poder, caso do Bocaiúva.

Ambigüidade esteve no enlace entre - na falta de melhor expressão - o "apetite" territorial da oligarquia brasileira, considerada como apoio relevante instauradora da República, mais ainda, no fato de terem sido os republicanos a negociarem tal área de Palmas em favor dos argentinos, assim que se iniciou o governo Provisório. Paradoxalmente, são republicanos quem haviam feito um acordo de doação de parte dessa área para o País vizinho, assim como dizem ser ganho republicano passado a utilizar-se desse resultado de litígio, em favor da causa maior, o Brasil República. Conclusão, o agrupamento republicano não deixou de ser tão heterogêneo e diverso, como qualquer grupo social e político humano parece ser, porque mediados por poder.

Os ufanismos daquele momento refletem também, em certa medida, respostas (e reposicionamento) às denuncias vindas dos monarquistas, de que republicanos eram um risco à nacionalidade, pois acusados de anti-patriotas, por terem propostos inicialmente dividir ao meio a área em que a Argentina contestava como sua. Se o nacionalismo estava em jogo, a conquista do território era forma de promover-se como mais nacional do que Outros. O ministro Quintino Bocaiúva, republicano histórico, assumiu logo no início da República a pasta do Ministério das Relações Exteriores e buscou implementar uma política que se representava como pró ativamente voltada aos países latino americanos, na tentativa do Brasil se reconhecer como República como eram demais países, ao mesmo tempo buscando neles reconhecimento do novo regime implantado.

\footnotetext{
${ }^{89}$ No conjunto das obras de Antonio Carlos Robert Moraes (2000), (ver o livro Bases da formação territorial do Brasil, por exemplo) o autor discute a noção de Fundo Territorial (expressão cujo crédito atribui a Lênin). Espécie de "poupança" de terras, de recursos e de bens e áreas, com enorme capacidade de serem convertidos em capital, lucro e exploradas, mesmo que possam estar durante certo tempo em não uso ou, aparentemente, abandonadas. Tal noção de "poupança de espaço" (res)guardada para valorização futura está embutida nas lógicas de colonização metrópole versus colônia, mas também influiu diretamente em várias concepções e práticas no Brasil na concepção territorial e nacional do País.
} 
Segundo opinião de muitos daqueles republicanos de primeira hora, o exclusivismo americano da política brasileira como monarquia, acabava por ser uma maneira de distanciar-se e não ser identificado com toda a América.

Entretanto, deve-se também entender como recorrer à própria categoria, arbitragem, como sendo um posicionamento bastante republicano, pois a Monarquia brasileira, junto com o governo chileno costumavam ser contrários a assumir apenas tal forma de chegada em acordo e, consenso nos litígios. Durante a primeira conferência Pan-Americana, quando a mesma estava ainda acontecendo, mudou-se o regime político do Brasil (da Monarquia para República) e nesse contexto, a posição brasileira é alterada, como explica Luís C. Villafañe G. Santos (2012, p.50):

Em novembro de 1889 ainda estava em curso, em Washington, a Primeira Conferência Pan-Americana, convocada pelo governo estadunidense. O encontro durou de 2 de outubro de 1889 a 19 de abril de 1890 e contava com uma agenda ambiciosa: desde temas políticos, como a arbitragem obrigatória, até a proposta da criação de uma união alfandegária que reuniria rodos os países do continente. As instruções para a delegação brasileira, preparadas pela diplomacia imperial, colocavam o Brasil contra todos os objetivos propostos para o encontro. $\mathrm{O}$ isolamento brasileiro só seria quebrado pela companhia do Chile que, vencedor da Guerra do Pacífico, não queria ver sua posse das províncias de Tacna e Arica, conquistadas no conflito, sujeitas ao exame e a uma arbitragem retroativa por parte de outros países. Com a queda do Império, a chefia da delegação brasileira passou a Salvador de Mendonça, um dos signatários do Manifesto Republicano, com a autorização para dar um novo 'espírito americano' às antigas instruções. Salvador de Mendonça passou a coordenar-se com os anfitriões e com a delegação argentina e conseguiu-se a aprovação do princípio da arbitragem obrigatória, com a abstenção solitária do Chile. (SANTOS, 2012, p.50). (destaques meus)

Foi, portanto, nessa conferência realizada nos EUA a decisão do Brasil em aceitar com os demais Países, o arbitramento na resolução dos litígios territoriais e internacionais na América. Buscava-se demonstrar maior posicionamento do Brasil com os EUA, desejando o reconhecimento rápido da República recém implantada; a afinidade entre ambos os Países passa a ser costurada diretamente, no âmbito da Conferência Pan-americana e mesmo a alternância do nome do País de Monarquia brasileira para Estados Unidos do Brasil, diz muito dessa aproximação.

$\mathrm{Na}$ conjuntura da passagem da Monarquia para República e a vitória brasileira na arbitragem, o paradoxo esteve no primeiro momento os criadores da República perceberem a partilha do território como maneira de se verem e integrarem como americanos, por outro lado, dois anos depois do fracasso de Bocaiúva, o discurso comum mais recorrente vira justamente o inverso: passa-se a apontar como a República foi quem possibilitou tal área não ser desagregada. Estou entendendo não ter havido 
interesse republicano como base de construção de nacionalismo, mas sim, dupla interpretação de destino a Palmas, cujo paradoxo refletia parte das disputas internas entre republicanos e parte importante, por sobrepor-se à Monarquia. O que talvez unia a ambos, esteve na busca de expressão da nacionalidade pelo território, perdê-lo (ou doálo) significaria nos tornarmos mais americanos, como defendia Quintino Bocaiúva. Mantê-lo (não dividir), significou ganho da causa republicana (que aproveitara o fato para), promovendo vínculos nacionais brasileiros, ajudar a apagar lembranças do regime monárquico. Como se pode entender, foi dado aquele espaço em litígio, diferentes atributos, camadas com variados sentidos, buscou-se atingir diferentes interesses.

A seguir, recuo ao tempo das últimas décadas do império para tratar de algumas representações de alguém a serviço do Império do Brasil, a partir da presença de um engenheiro geógrafo cartógrafo na área de litígio com Argentina. Pretendo discutir outra forma de uso dessa competição pelo domínio da posse do espaço, do ponto de vista alguém presente, que leu o momento e tirou vantagem. Aponto também, mesmo não tão diretamente e a partir de exemplos desse personagem, a existência de levantamentos da área na política imperial, buscando maior reconhecimento territorial.

Engenheiro geógrafo cartógrafo e o mapa Questões dos Limites. Emil Odebrecht nas tramas das representações do espaço cartografado na geo(e)política no Império

"Há pouco recebi as férias solicitadas e irei passar a festa de Natal com os meus, deixando para o próximo ano os trabalhos no Iguaçu. Então, minha velha Mãezinha, feliz. Anovo Novo!"

(Emil Odebrecht, 1882)

Assim nessa despedida, na epígrafe acima, ia encerrando o engenheiro geógrafo e cartógrafo, uma carta de final de ano destinada à sua mãe na Alemanha. Ele avisava estar entre Guarapuava (PR) e Guairá, mais precisamente em Ivaí (PR). Informa na correspondência, tratar-se do local para preparo da instalação de telégrafo, "No momento trato dos preparativos para a exploração da região das Missões até ao Paraná, onde em breve deverão ser instalados os telégrafos e trens." (ODEBRECHT, 2006, p.388). O alemão naturalizado brasileiro há mais de uns 20 anos não via seus familiares - pai, mãe, irmãos etc. - na Alemanha (tendo ele vindo ao Brasil em 1857 e, morar definitivamente, em 1861). Mas matinha correspondência com certa frequência e regularidade com membros da família (“os" Odebrecht) ficados na Europa. 
A depender em qual lugar do território do Brasil estivesse - reclamava - era mais rápido e fácil comunicação com o exterior, do que entre as regiões brasileiras. Como disse na carta datada de outubro de 1888 para sua irmã na Alemanha, as correspondências das áreas urbanizadas com o coração do Brasil (representado como sendo "as selvas") era mais difícil do que com a Europa: "Com certeza deves ter notícias mais recentes de [minha esposa] Berta do que eu, visto que as cartas demoram aproximadamente dois meses para chegarem de Blumenau até aqui, ao coração da selva brasileira." (ODEBRECHT, 2006, p.422). Sua esposa Berta, quando escreveu de Blumenau para cunhada na Alemanha, descreve o mesmo: "A carta de Emil para ti demorou quatro semanas da Serra até aqui, demorou mais do que as cartas que vêm daí. Por certo o Emil entregou a carta a um tropeiro, eles costumam demorar este tempo." (ODEBRECHT, 2006, p.424).

Ele próprio havia - segundo Emil informa em carta de maio de 1882 remetida de Curitiba, para sua mãe - trabalhado atuando no "término dos trabalhos de exploração das linhas telegráficas daqui até a região de Missões e ao Paraná.” (ODEBRECHT, 2006, p.386). Há tempo envolvido em instalações de linhas telegráficas e medições de áreas, Emil desejava ter um posto de trabalho fixo, mais próximo da esposa e dos filhos, na região da colônia Blumenau (SC). No final do ano seguinte, em 1883, escrevendo de Guarapuava (PR), pronunciando ter que retornar, ainda, para a região por ele considerada selvagem: "Infelizmente a minha esperança de receber um cargo mais confortável e próximo ao Itajaí ainda não se concretizou, e após as minhas férias terei de voltar mais uma vez ao selvagem oeste dessa Província!" (ODEBRECHT, 2008, p.395).

Foi nomeado em 1881 para Repartição Geral dos Telégrafos e durante aproximadamente os seis anos seguintes - de 1882 até 1888 - esteve em campo (emprestado à Comissão Mista da Fronteira), na área do litígio em que a Argentina reivindicava a posse. O levantamento do terreno, os trabalhos de campo com referencial de localização geográficas, as informações e anotações produzidas por Emil Odebrecht sobre a área, prospecções levadas ao Império pelo Barão de Capanema ${ }^{90}$, reforçam a

\footnotetext{
${ }^{90}$ Guilherme von Schüch, o Barão do Capanema, possuía amizade pessoal e canal de contato direto com D. Pedro II. Engenheiro, Capanema chefiou os telégrafos e era filho do naturalista Rochus Schüch que veio ao Brasil com a comitiva da (esposa de D. Pedro I) Maria Leopoldina. Segundo Silvia F. de M. Figueiroa (2005, p.439): "O engenheiro e naturalista Guilherme (Wilhelm) Schüch, Barão de Capanema foi sem dúvida, um expoente da elite imperial que circulou por importantes espaços institucionais científicos e técnicos, tendo atuado de forma bastante significativa para a implementação da uma cultura técnica-científica no Brasil e para o consequente fortalecimento da engenharia e dos engenheiros, assim como das ciências geológicas e naturais. Sua trajetória profissional, talvez até por circunstância da origem
} 
existência de uma política direta sob financiamento da corte, no conhecer ao máximo possível aquele espaço. Na geopolítica do Império, a figura de Emil Odebrecht ajuda a compreender tanto as concepções de um europeu no - por ele - considerado "mundo selvagem", assim como, de uma clara intenção no Segundo Império de levantar informações favoráveis a tal espaço continuar fazendo parte do Brasil. A concepção de destino do espaço é certamente diferente daquela atribuída dos primeiros republicanos.

Antes de detalhar mais a respeito de Emil Odebrecht, gostaria de chamar atenção para dois aspectos pertinentes, a seguir:

Título do Box 2: De Blumenau para o Império, do Império para a República

a) Primeiro, de onde vem ${ }^{91}$ o técnico contratado para atuar nessa área do litígio com a Argentina? Vem de Santa Catarina, mas não de Desterro. Não, portanto, da capital da Província, mas da colônia Blumenau - essa pertencente formalmente à Itajaí até 1882 - permitindo fazer uma ilustração de exemplo em relação ao discutido no capítulo anterior, sobre a não polarização de Desterro ou, de Santa Catarina passar a não ter na sede administrativa da Província uma capital "completa". A própria localização do escritório sede para os trabalhos na área de litígio estava em Curitiba, segundo Emil Odebrecht comenta em suas comunicações. Tal lugar (sede do escritório) de planejar os trabalhos na área de Palmas não sendo Desterro, pode ser associado à sua baixa interação ou não tanta capilaridade discutida no $1^{\circ}$ capítulo, anteriormente (ver: capítulo I).

b) Segundo aspecto que gostaria de chamar atenção está no fato do Barão do Rio Branco, estudar, trabalhar, deixar anotações e elaborar análise de conhecimento (na elaboração da defesa do Brasil quando da entrada na arbitragem) a partir de mapa produzido e elaborado com bastante atuação de Emil Odebrecht, como veremos. Isso permite, de saída, apontar duas características fundamentais: como a lógica de argumentação, para a defesa da área ser do Brasil buscará, a base de origem colonial. Da América portuguesa, portanto, dos usos do espaço ao interesse de Portugal e segundo; a base cartográfica de trabalho é resultado da geopolítica do segundo reinado, como a produzida por Emil Odebrecht, "financiada" com claro interesse do Império.

Levantamentos de Emil Odebrecht são mais do que produção cartográfica

familiar - já que seu pai chegou ao Brasil como integrante da comitiva da Imperatriz Leopoldina de Habsburgo -, esteve inextricavelmente vinculado ao Segundo Império."

${ }^{91}$ Seria pertinente detalhar uma rede étnica nas comissões e trabalhos telegráficos do Império (como a "Repartição Geral dos Telégrafos"), pois alguns documentos dão pistas nessa direção. Em carta a Hermann Blumenau (ex-diretor da colônia cujo seu nome leva, Dr. Blumenau já havia partido do Brasil) o Barão do Capanema agradece a indicação de Emil: "Enquanto Odebrecht se encontrava com sua turma num barranco do Iguaçu, entre os rios Chopim e Paraná, Capanema escreve longa carta em Curitiba, em 10.08.[18]83, ao Dr. Blumenau, que se encontrava na Alemanha [...]: 'Estou voltando de uma cavalgada a Guarapuava, onde inaugurei a Estação Telegráfica, vistoriei as picadas abertas pelo meu pessoal e o traçado da estrada que tem aclive constante nada maior que $8 \%$. Primeiramente tenho que expressar-lhe meu agradecimento pela recomendação de Odebrecht'." (ODEBRECHT, 2006, p.158-159). Um dos elogios mais recorrentes de Emil à Capanema (nas cartas que engenheiro Odebrecht escreve para família) era por conversarem, Barão e ele, em língua alemã. 
Emil Odebrecht (1835 - 1912) exerceu diferentes funções como funcionário do Ministério da Agricultura, Comércio e Obras Públicas. E antes disso, durante a Guerra contra o Paraguai recebeu credibilidade por ter sido voluntário pela colônia Blumenau (pertencente ao município de Itajaí, cujo desmembramento se daria a partir de 1882). Em Santa Catarina foi, por exemplo, diretor adjunto da colônia Azambuja, no sul da mesma província. Tendo feito seu lugar de moradia ${ }^{92}$ no Vale do Itajaí "Trabalhou ao lado do Dr. Blumenau, encarregado da demarcação e medição dos lotes coloniais e da exploração dos caminhos que ligariam a nascente colônia com o planalto e com outros centros de população da província." (BLUMENAU EM CADERNOS, 1958, p.135).

Quero sugerir discutir aqui no presente tópico desse segundo capítulo, como um "não nativo brasileiro" - um não nascido no do Brasil, mas naturalizado - também fez uma leitura dos (seus) trabalhos na área de disputa. Ele buscou acessar algum ganho em ter levantado informações sobre o espaço.

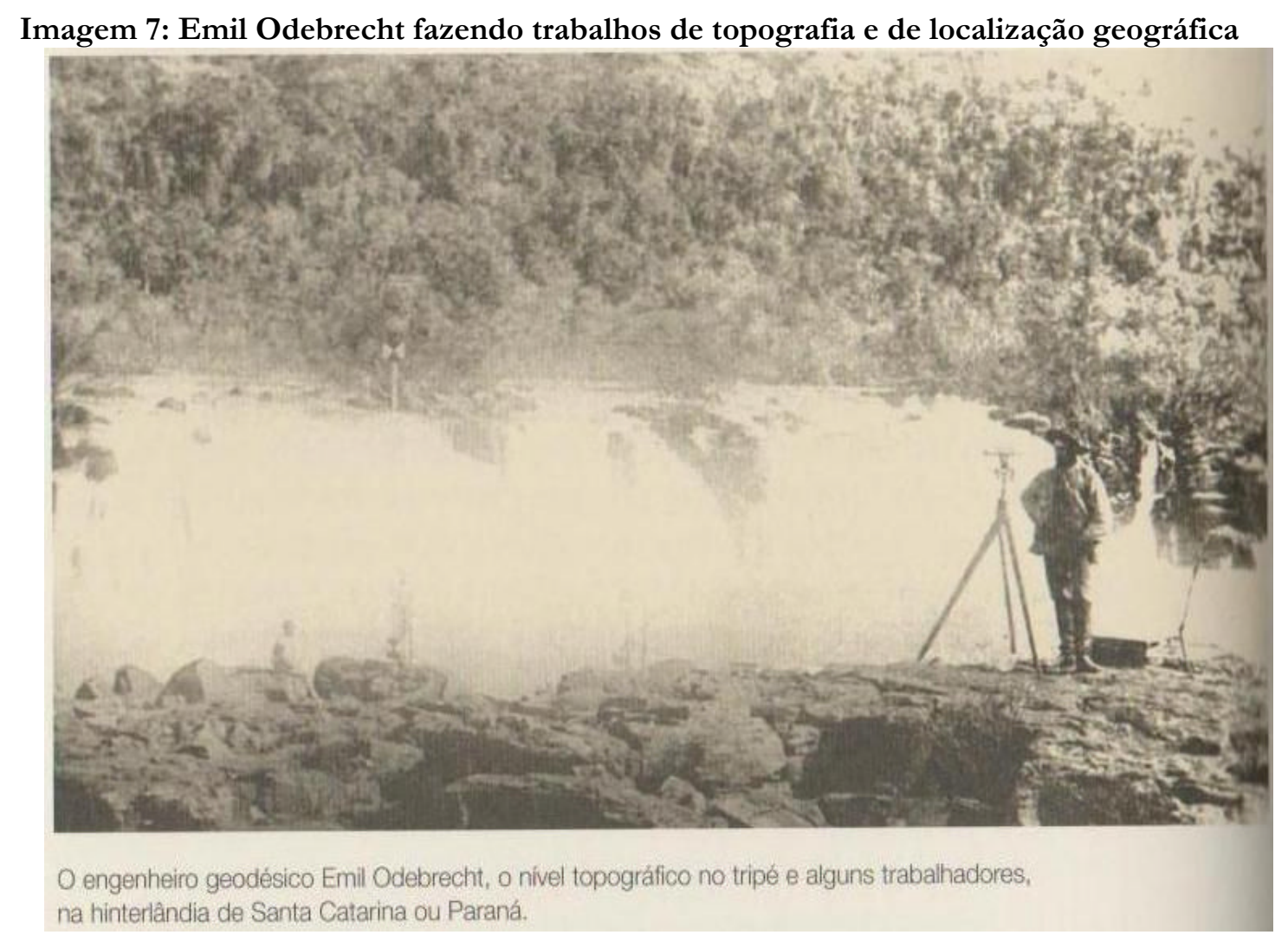

Sem confirmação do lugar, provavelmente sendo área em litígio (ref. ODEBRECHT, 2006, p.166)

\footnotetext{
${ }^{92} \mathrm{Na}$ carta de 18 de agosto de 1878 para mãe e irmãos, Emil expressa do seu patrimônio em Blumenau e antes, caracteriza como "selva" o início de uma colônia no qual dirige e, de onde desejava sair para retornar à sua casa: "Conforme já lhes escrevi em cartas anteriores, fui transferido para uma recémfundada colônia no sul da Província de Santa Catarina, felizmente em caráter provisório, já que eu veria como impossível viver nesta selva com a minha família, onde falta até o imprescindível para a sua manutenção: escola, médico, comunicação, etc., além disso investi uma quantidade por demais grande na minha propriedade, de modo que nem poderia me desfazer dela agora, sem ter prejuízo significativo; tenho porém a certeza de voltar ainda no decurso deste ano.” (ODEBRECHT, 2006, p.383).
} 
Emil não teve tanta sorte no projeto de logo voltar a ser indicado em trabalhos pelo Vale do Itajaí. Previu errado o tempo ${ }^{93}$ e a possibilidade de conseguir obras nas proximidades e cercanias de Blumenau, aonde estabelecera a família. Passados mais de dois anos, em janeiro de 1885, escreveu de Blumenau para Alemanha, ainda vinculado aos levantamentos topográficos nas áreas de litígio: “Quando essas linhas [que escrevo] chegarem a Anklam [Alemanha], já deverei ter partido para a minha viagem às Missões e ao Rio Uruguai, para fazer um estudo dos terrenos entre o Iguaçu e o Uruguai [...]." (ODEBRECHT, 2006, p.404). Às vezes e sem regularidade, Emil tentava visitar a família nuclear em Blumenau, mas chegou a ficar 13 meses direto nas terras do litígio.

Exercendo funções com bastante mobilidade e pouca fixação próximo da família (tal distanciamento era recorrente nas suas lamentações), principalmente entre as décadas de 1870 e 1880. Chamo atenção para outra forma de utilizar do litígio, como tratarei a seguir; problematizando o próprio uso do atuar na área, como possibilidade de mobilizar acessos e abrir portas aos próprios familiares (filhos) de Emil Odebrecht.

A partir de algumas das correspondências privadas, cartas trocadas com seus familiares, sugiro apontar como o engenheiro geógrafo cartógrafo representou e viu, a área do litígio em que atuou diretamente em campo. Seria mais evidente tratar, apenas, do engenheiro descrevendo como hostil, inóspito, distante e um nada "perdido" - mas que Brasil e Argentina não queriam perder - a considerada selvagem área.

Acredito, um alemão mesmo naturalizado a exercer papel na delimitação de uma parte do território nacional, desperta atenção pela complexidade das identidades a permearem tais discursos (germânico no auxilio da manutenção de terras para o Brasil). Passarei pelas representações da natureza selvagem do "Brasil distante". Mas, aponto na conclusão do tópico: ele acessou rede de relações no Império visando outros objetivos.

\section{A Alemanha que se via desde o Brasil. O Brasil visto com olhar alemão}

Na década anterior a sua ida para as áreas das Missões (como ele próprio assim chamava), percebe-se nas suas correspondências para família da Alemanha, o momento político de comoção e união do Estado nacional moderno alemão. Muitas das opiniões do engenheiro Emil sobre o Brasil, contidas em suas cartas, tratam de influências dessa

\footnotetext{
93 Em 13 de janeiro de 1883 escreveu na carta para a mãe: “Amanhã início a minha viagem para Guarapuava e de lá até o Iguaçu, para explorá-lo até sua foz no Paraná, um trabalho que deverá durar um ano." (ODEBRECHT, 2006, p. 388). Emil acabou ficando mais 5 anos; até 1888 esteve na região, nesse período tendo estado com sua família no Vale do Itajaí sem regularidade, uma vez por ano, em média.
} 
conjuntura de fundo: um contemporâneo da unificação e formação alemã, mesmo aparentemente olhando de longe, desde solo americano para terras da Europa.

Na correspondência de março de 1871 é possível perceber como se acompanhou da colônia Blumenau, alguns fatos da Guerra Franco-Alemã. Inclusive, mandou-se capital doado pelas pessoas da comunidade, daqui, para a Alemanha em Guerra. O fato de terem formado um fundo com apoio em dinheiro e o envio do mesmo, pode apontar para manutenção de contatos e mesmo vínculos de pertencimento ou estar envolvido sentimentalmente com o País da Europa: "Vocês nem imaginam o quanto esta guerra deixou-nos nervosos e como ainda nos preocupa." (ODEBRECHT, 2006, p.381). Assim disse o engenheiro atento a terra em que moravam seus pais, em carta para eles.

Emil escreve lamentar estar fora da colônia, fazendo-o perder a festa, pois, segundo informa aos familiares, ocorreu em Blumenau comemoração pela vitória alemã: "A notícia da capitulação de Paris foi aqui recebida com grande júbilo, infelizmente não pude participar das grandes festividades, pois estava enfiado no mato." (ODEBRECHT, 2006, p. 381). Pede desculpa aos familiares pelo que considerou envio de poucos recursos, dizendo a colônia Blumenau não estar recebendo investimentos suficientes da Corte, além da mesma ser nova, recente. ${ }^{94}$ Assim, explicou justificando não ter sido enviado mais apoios em recursos: “[...] não tivesse esta Colônia em seus inícios sido tão tristemente abandonada, até reprimida pelo governo (com as outras colônias acontece quase o mesmo), a coleta teria alcançado bem outro resultado." (ODEBRECTH, 2006, p.381).

Além de escrever ter ficado apreensivo pelo irmão militar (Rudolph), nas forças armadas na época da guerra Franco-Prussiana, vai avaliar defendendo certa capacidade de observação causada pela distância; vista de longe, a Alemanha seria para Emil, um só País. Unido: “Aqui no exterior vê-se como o alemão é amalgamado com sua pátria, o quanto ele ama a terra onde nasceu." (ODEBRECHT, 2006, p.381).

É com essa experiência de vivência prévia em outra nação, no País de origem, cujo enquadramento "prévio" é utilizado para interpretar o Brasil, como aparecia para Emil: "desordem costumeira do país”, cujas correspondências enviadas para família, por exemplo, estavam sendo prejudicada pelo desmazelo do serviço postal. Ou, em outro caso, a chegada de vírus por culpa do que Emil considerava ser, do não cuidado dos agentes do Estado: "Poucos meses após a minha partida de Blumenau a varíola foi

\footnotetext{
${ }^{94}$ Na década seguinte, em março de 1882, diz o inverso, como "a colônia está em condição de viver por si só." (ODEBRECHT, 2006, p.385).
} 
introduzida no país, trazida por navios aportados no Rio [de Janeiro], em consequência da imperdoável displicência das instituições públicas." (ODEBRECHT, 2006, p.384).

Desapontado, desabafava nas cartas para seus familiares, suas críticas sobre o Brasil, entendendo como a principal falta, a não coerência da administração: "o Governo taxou os produtos transportados de uma província para outra!" E avaliava ironicamente: "Por aí tu podes deduzir quão sábia é a providência do Governo daqui" (ODEBRECHT, 2006, p.386). Nas suas cartas, Emil fazia regulares críticas ao Estado brasileiro, mas também buscou acessá-lo de alguma forma, é assim como o interpreto.

Suas referências estão na Europa, percebe-se claramente nas avaliações feitas do Brasil, tendo como um ideal de Alemanha, exemplo do parâmetro para suas análises. Ao mencionar em uma correspondência, avaliando positivamente a gestão do gabinete cujo mais tempo exerceu presidência no Segundo Império, o Visconde de Rio Branco (pai do Juca Paranhos, futuro Barão do Rio Branco, como veremos), Emil o compara ao famoso chanceler prussiano. Talvez, também para exemplificar aos seus familiares na Alemanha qual sua consideração sobre o Visconde, o denominou como sendo, "Paranhos, o Bismarck do Sul." (ODEBRECHT, 2006, p.382).

Como se percebe nesses exemplos, o vínculo com a Alemanha continuava estreito, inclusive fazendo levar seus filhos para "estagiarem" em casas de comércios de outras localidades ou municípios da Província, para aprenderem o idioma português habituados como estavam no falar dialetos alemães em Blumenau -. A sensação de simultaneidade com a Alemanha, não significou não ter existido vivência intensa do que ocorria no Brasil. Acompanhava sua trajetória de imigrante com nacionalidade brasileira, uma inserção bastante favorável em algumas relações sociais, como no trabalho de telégrafo. Quero mencionar, como exemplo de sua adaptação brasileira, o fato dele ter enviado regularmente notícias do Brasil para seus familiares da Alemanha, como o que passou a se tornar problema - as cheias - o transbordamento do Rio ItajaíAçu; quando em 1880, segundo seu relato, 40 pessoas se afogaram. Na mesma carta, menciona a fome causada pela falta de água em uma região já bem mais distante de Santa Catarina; o que permite perceber estar socializado e bem informado (e querer informar) sobre o Brasil, como escreveu em 30 de setembro de 1880 para àqueles da Alemanha: "Vocês com certeza já leram nos jornais que no norte do Brasil milhares morreram de fome porque a seca que já perdura há anos está matando toda a vegetação.” (ODEBRECHT, 2006, p.383). 
A respeito da hipótese de ter existido uma rede étnica dentro de algumas estruturas do Estado monárquico brasileiro, um depoimento de Emil Odebrecht reforça essa forte possibilidade. Ele menciona como no Departamento de Telégrafos a maioria dos funcionários é de alemães, de maneira que havendo algum interesse seu, de transferir-se (saindo do Ministério da Agricultura, onde estava), é para tal instituição preferida. Diz, em carta aos familiares, como já havia tomado a providência na instituição de avisar sua preferência de ser alocado nesse setor (dos Telégrafos) em que há, segundo Emil, alemães na maioria dos funcionários. E é o que realmente faz, originalmente funcionário do Ministério da Agricultura, Comércio e Obras Públicas, em 1881 é nomeado inspetor da Repartição Geral dos Telégrafos.

Antes de iniciar trabalhos nas Missões, Emil estava encerrando outro trabalho de medições das divisas ("Leste”) próximas ao litoral entre as Províncias de Santa Catarina e Paraná, após encerrado esse processo, ele iria ao Oeste, devendo antes findar levantamento dessa faixa mais litorânea. "Conforme já lhes escrevi, tive de deixar os meus [filhos e esposa] em meados de janeiro para terminar os levantamentos geográficos dos terrenos entre Dona Francisca e Morretes." (ODEBRECHT, 2006, p.385). Segundo aparece nessa documentação de origem privada (fundo de trocas de cartas entre os familiares), ele dizia estar satisfeito principalmente com a notícia de aumento do salário. Emil era um funcionário do Estado imperial brasileiro e nas cartas desse período, não reclama do valor ganho, ao contrário, faz elogios de como seu recebimento tomara boas proporções. Esse ponto precisa ser destacado.

Diferente do contentamento com o salário recebido, menor elogio era atribuído a floresta a qual adentrava. Descrevendo um deserto monótono, formador do espaço não civilizado, pois natural; é de aparência negativa nos relatos de Emil Odebrecht sobre as áreas das Missões: “Aqui nestas quase ilimitadas selvas virgens tudo é quase igual como no alto mar ou no deserto de areia: a eterna monotonia é cansativa, ainda mais que com um olhar, apenas, se vê tudo de uma vez só.” (ODEBRECHT, 2006, p.390).

Das concepções dessa área que Emil esteve aproximadamente seis anos, levantando informações entre maio de 1882 até dezembro de 1888, descrevia-se como atuando em serviços por jornadas. Certamente os tipos de levantamentos e saberes daquele espaço interessavam diretamente à geopolítica da coroa, por mantê-lo tanto tempo seguido em trabalhos de campo. Em grande quantidade das cartas por ele escritas, aparece a regularidade com que dizia desejar finalizar seus levantamentos geográficos das Missões. Percebe-se na leitura das cartas, como esteve sempre pensando 
em encerrar um ciclo de trabalhos e logo conseguir o plano, cada vez mais postergado, em ser remanejado para perto dos familiares - esses que denominava nas cartas aos outros - como sendo "os meus". Em uma das primeiras cartas suas vindas da área em litígio, diz do sonho e da frustração de alguém vindo da (expressão dele) supercultura:

Que eu no momento estou metido nas profundezas da selva e ocupado com a exploração do Rio Iguaçu. [A esposa] Bertha certamente já te escreveu, provavelmente ficarei longe de casa mais uns cinco a seis meses, já que estes serviços serão prosseguidos até o rio Paraná; então espero conseguir um emprego definitivo mais cômodo em Blumenau (pelo qual muito almejo). Eugen acredita que a vida aqui na selva teria fatos e coisas fascinantes e interessantes - para um europeu citadino vivendo numa supercultura! -, mas não! (ODEBRECHT, 2006, p.390)

Para Emil, segundo expressou nas suas cartas, não pareceu nada confortável resistir nas funções a ele atribuídas. Penso ser legitimo problematizar: por que, afinal, deve ter ficado então mais de meia década em levantamentos dos terrenos nas áreas do litígio? Acredito não haver uma única resposta unidirecional, mas percebe-se pelas cartas enviadas, além dos fatores como afinidade e cumprimento de funções a ele dadas a quem estava subordinado (ao Barão de Capanema), o bom salário e dívidas que menciona ter feito ou desejo de poupança. Mas também ao fato de buscar colocar algum de seus descendentes, no quadro de funcionários dos telégrafos ou de outras instituições do Estado Imperial brasileiro. Foi com trabalhos de geodésia, agrimensor, geografia, topografia... enfim, de levantamento e refinamento de informações sobre o espaço, nesse processo percebeu caminho de destaque, abrindo outras portas, para ele e os seus.

\section{Sucesso na polêmica Questão do litígio: engenhosa rede de apoio ou ascensão}

O que parece ter feito permanecer tanto tempo no Oeste e justifica sua presença “aqui na floresta virgem", em circunstância por ele descrita como estando separado da família e passando por privações muitos meses, se devia, nas palavras do próprio Emil, ao "salário que me possibilitará oferecer aos meus a garantia de sustento. Eu havia feito grandes dívidas, agora este problema já passou, e poderemos reservar a metade do meu salário sem que nos falte nada." (ODEBRECHT, 2006, p.391). Antes de tudo, parece o emprego fixo com garantia de certa estabilidade (mesmo que naquela época do séc. XIX parece ter ocorrido momentos em que o Estado fazia demissões ${ }^{95}$ ). Sendo, a

\footnotetext{
${ }^{95}$ Comentário da explicação do próprio Emil, em carta de agosto de 1878: "A situação do Brasil é no momento extremamente triste, a falência do Estado é iminente, e em função disso está havendo um
} 
regularidade do bom salário, um dos aspectos muito mencionado por Emil como positivo na valorização de seus serviços como geógrafo cartógrafo.

Mas, não fora apenas a remuneração e os ganhos seja como funcionário cedido à Comissão Mista de Fronteira, seja na Repartição Geral dos Telégrafos (em 1888 é nomeado engenheiro chefe do distrito de Santa Catarina na Repartição dos Telégrafos, cargo no qual se aposenta em setembro de 1891), mas principalmente uma figura muito influente na rede de contatos acessada. Houve no exercício dos trabalhos de levantamentos do terreno na área de litígio, um contato direto e mais íntimo com algumas autoridades do Império, particularmente com o considerado Barão do Telégrafo, o Barão de Capanema. Nos mais de seis anos em campo, Emil Odebrecht foi algumas vezes até o Rio de Janeiro ou Curitiba levar informações e explicar os trabalhos de reconhecimento; como se percebe na carta de outubro de 1886, sobre o fim do ano:

Infelizmente vou ter que passar a Noite de Natal no Rio de Janeiro, para onde fui convocado para uma conferência com o Assessor do Barão de Capanema, Chefe da Comissão de Regulamentação das Fronteiras. Depois disso poderei descansar alguns meses em Blumenau, já que os trabalhos das Comissões de ambos os lados só começarão em abril. (ODEBRECHT, 2006, p.416)

Em circunstâncias públicas, de ações do Estado monárquico, por exemplo, às vezes era uma das autoridades presentes junto do Barão de Capanema. E chegou a ser mencionado nominalmente, nas cartas que Capanema enviada ao Imperador Pedro II, como na qual o Barão informa, em 1888, o mapa da área estar próximo de ficar pronto:

Tenho a honra de levar ao conhecimento de V. Excia. que acabo de receber ofício do auxiliar da Comissão de Limites, Engenheiro Emílio Odebrecht, datado de Porto União da Vitória, em $1^{\circ}$ do corrente, participando-me que havia terminado em comum com os auxiliares argentinos, tenentes Montes e Meneses, o reconhecimento do Rio Jangada. O engenheiro Odebrecht levantou a planta do Rio Iguaçu, do Porto União até a foz do Jangada, ligou este a alguns pontos da triangulada, e verificou assim a exatidão da planta levantada pelos oficiais do contingente. Quando chegaram os oficiais argentinos eles verificaram e conferiram essa planta desde o ponto em que eles tinham levantado o rio até a sua foz, encontrando tudo conforme, retiraram-se para Curitiba, onde foram entregues as plantas para incluir no mapa geral do território litigioso, e brevemente de este estar concluído. (ODEBRECHT, 2006, p.165)

Em algumas das correspondências, diz Emil aos seus familiares, comunicava-se ele e o Barão de Capanema em língua alemã, fato assumido pelo próprio Emil com vaidade e muita satisfação. Em novembro de 1883 escreveu em carta estar aguardando o Barão em Guarapuava (PR) para a inauguração dos telégrafos. E segundo captou da 
interação entre ambos, entendeu uma simpatia e disposição em favor dele; Emil deixou o registro quando escreveu à esposa: "O Barão faz tudo o que percebe ser do meu anseio ou gosto." (ODEBRECHT, 2006, p.393). E aproveita para avisá-la pela mesma carta, ao terminar as coordenadas em Palmas e Chopim, ele irá passar dessa vez, as festas de final do ano com a família. "Somente terei de determinar mais algumas coordenadas em Palmas e Chopim, e então viajarei diretamente ao Itajaí, provavelmente por Curitibanos." (ODEBRECHT, 2006, p.393). Pois, o Barão - Emil, avisa a esposa - "ele mesmo me ofereceu férias em Blumenau, sem que eu as tivesse solicitado." (ODEBRECHT, 2006, p.393).

Em 1883, Emil informa na carta para esposa ter conseguiu realizar marcações (de localização) importantes, no minucioso levantamento do espaço. Ele demoraria ainda mais cinco anos atuando até 1888 (informação anacrônica, posto que ele não sabia até quando ficaria nos trabalhos das Missões; sabemos agora, olhando o passado). Ali, logo no primeiro ano de trabalho, Emil já percebeu como sua função começara a receber destaque (mais importância) e mesmo imbuída de uma questão internacional de certo peso. Era a valorização do território - e a centralidade da dimensão espacial no Brasil como sempre nos lembra Antonio Carlos R. Moraes - na influente concepção brasileira sobre o País que Emil vai vivendo, percebendo e tentando, a partir da importância que dão aos seus trabalhos de terreno, galgar oportunidades para si e os seus. "Também tenho a certeza de que meu trabalho serviu para esclarecer a dúvida sobre a questão de fronteiras, tão importante para o Brasil quanto para a República Argentina, uma missão que já muitos tentaram cumprir antes de mim, mas não tiveram o mesmo sucesso." (ODEBRECHT, 2006, p.393).

Uma reflexão de análise do tempo de seus trabalhos nas Missões nota-se uma política do Império - se não para resolver em definitivo a questão litigiosa, ao menos para se cercar ao máximo de informações favoráveis ao Brasil. A busca de quem consegue legitimar sua verdade do espaço esteve na disputa entre Argentina e Brasil. Quando do dossiê e exposição de documentações ao árbitro, entregue por Rio Branco nos EUA em fevereiro de 1894, o Barão faz menção tanto a Emil como ao argentino, ambos representantes dos seus respectivos Países na Comissão Mista, nessa seguinte passagem: "O reconhecimento do [rio] Jangada, ou San Antonio Guazú, foi feito em consequência da decisão, por uma partida mista dirigida pelo engenheiro Odebrecht (Brasil) e pelo tenente Montes (República Argentina).” (RIO BRANCO, 2012, p.252). 
Em janeiro de 1887, na carta para familiares da Alemanha, parece ser claro a expectativa de quem trabalhava na linha de frente no "conhecimento da área", como a chegada ao fim do levantamento se daria logo. Em consequência, o reconhecimento da posse do Brasil; ideia nas cartas de Emil, ele acreditava como logo iria findar o litígio:

Em maio [de 1887] voltarei às Missões, por Curitiba, onde uma Comissão Argentina-Brasil à qual também pertenço, trata dos assuntos relativos à fronteira; espero que a mesma chegue à conclusão ainda este ano, então terei meu próprio campo de ação definitivo aqui perto, talvez já logo em Blumenau [...]. (ODEBRECHT, 2006, p.417)

Quando mais próximo de finalizar os trabalhos de campo nas Missões, mais próximo Emil parecia garantir uma transferência de trabalho, indo fixar-se no Vale do Itajaí. Exercendo alguns papéis parecidos com profissões atualmente conhecidas ou denominadas de Topógrafo, Engenheiro Cartógrafo, ou Geógrafo georeferenciador (entre outas), Emil percebeu como passou a ser cada vez mais aprovado (requisitado) pelo valor atribuído ao espaço da área em litígio (e por isso ficou nela, 6 anos).

O firme propósito de manter a área pertencente ao território brasileiro e a disputa pela Argentina e Brasil, acabaram valorizando seus levantamentos de campo e Emil compreendeu esse contexto e foi até o fim nesses trabalhos, utilizando possibilidades de retornos positivos a serem colhidos; como fez. Desse saber ao qual o poder agiria melhor e resultaria uma das principais maneiras de arguir o domínio do mesmo. Saber das potencialidades e realidades do espaço é saber dominá-lo ou saber o que estaria se perdendo, mas é também buscar conhece-lo ao máximo, para mais e melhor legitimar a manutenção de sua apropriação. Emil exerceu papel do sujeito chancela do saber/poder:

[...] não há espaços de poder que não sejam imediatamente espaços de saber. Isto exige do historiador da região que se questione sobre os saberes que lhe deram forma, que lhe deram identidade, que a definiram, que a demarcaram, que lhe deram uma visibilidade e uma dizibilidade, que a nomearam, que a recortaram, que lhe deram rosto, característica. Um dado recorte espacial é sustentado, explicado, justificado, legitimado por dadas formas de saber, que se materializam em ações e discursos, práticas discursivas e não-discursivas. A região é, em grande medida, fruto dos saberes, dos discursos que a constituíram e que a sustentam. (ALBUQUERQUE JÚNIOR, 2008, p.58-59)

Se relacionarmos com uma obra publicada em 1895, já após o fim do arbitramento, percebe-se melhor a ideia de convicção da importância da área, por ser antes de tudo, terra. Mas também, segundo o texto A propósito da Questão Missões, de autoria de Alcides Cruz (1895) disponível na Biblioteca do Arquivo Histórico do Itamaraty (no Rio de Janeiro), o fator concorrência parece ter sido levado em conta na disputa e na valorização do mesmo. "A tenacidade e empenho sustentado pela 
Argentina para se apoderar desse quase El Dourado equivalem a uma verdadeira propaganda em favor dele." (CRUZ, 1895, p.14).

Para o pensamento brasileiro do momento, a busca da Argentina para dominar o espaço, ajudava a significar amplitude de valores atribuídos ao mesmo. Ao desconfiar da intenção argentina, como se indo com tanta sede ao pote, fazia o lado brasileiro valorar ainda mais a área e querê-la manter para si.

Logo que Emil percebeu a altura atribuída às suas funções, passou a questionar como através dela retornaria para eles (a esposa, os filhos...) mais ganhos, além, "apenas", do salário. Haveria mais conquistas e vantagens? Talvez começasse a traçar maneiras de converter o reconhecimento dos trabalhos de levantamento de terreno e de produção de uma mapa; mais benefícios tudo isso poderia gerar: "Será que finalmente, uma vez, este sucesso me trará alguma vantagem?” (ODEBRECHT, 2006, p.393). Essa pergunta, a esposa Berta leu na carta em que Emil comentava do seu bem-sucedido trabalho de levantamentos nas Missões.

Emil Odebrecht pode ser localizado como um personagem parte desse processo de conhecimento da área na geopolítica do Império. Exercendo papel de se submeter a "ser indivíduo fronteiriço", mas nesse caso, considerado o portador de elementos da modernidade: possuidor da técnica e da competência, um não brasileiro a ajudar a melhorar o Brasil, na concepção da época. Era indivíduo na fronteira, particularmente, identitária, de alemão e brasileiro, como se "abrindo à modernidade" na selva.

$\mathrm{Na}$ percepção de Emil, Barão de Capanema estava bastante satisfeito com seu trabalho. Confessa a mulher a grande possibilidade de no ano seguinte fazer excursões diplomáticas, ainda secretas em 1883. Será dos resultados desses trabalhos nas áreas de litígio, segundo ele previu: "através deles me tornarei conhecido e sei que poderei ajudar muito os nossos meninos, por exemplo, deverá ser fácil conseguir algo para o [filho mais velho] Edmund na Oficina dos Telégrafos no Rio [de Janeiro], mais tarde quando ele tiver aprendido bem seu ofício." (ODEBRECHT, 2006, p.393). (destaquei)

Realmente se concretizou tal abertura de caminho para ascensão social e contatos chaves aos herdeiros. Basta lembrar como o filho mais velho, Edmund Odebrecht foi funcionário da Oficina dos Telégrafos no Rio de Janeiro e mesmo para o filho mais novo, mais tarde quando "[...] mandou o caçula dos rapazes, Adolf (nasceu em outubro de 1882), para a Escola de Engenharia do Rio de Janeiro, onde se formou,

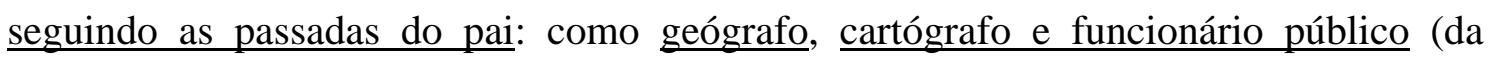
Repartição dos Telégrafos).”(ODEBRECHT, 2006, p.382) (destaques meus). 
O caso do litígio aqui tratado é justamente da figura que é atribuída papel definidor de garantir essa área. Como mais em frente veremos às imagens atribuídas ao Barão do Rio Branco: uma espécie de progenitor do espaço. Sem antes finalizar, lembro depois de tanto tempo servindo ao Império nos levantamentos de área, enfim, Emil Odebrecht conseguiu retornar ao Vale do Itajaí, em um melhor cargo e situação que ficou uma década planejando chegar. O ajudar no conhecimento do (saber do) espaço lhe abriu caminhos, e o Estado brasileiro era seu ganha pão e da família. Contato com o Barão do Telégrafo facilitou caminhos aos seus. Parece, adentrar a selva nos trabalhos geográficos, lhe valeu. E aos descendentes também. O Estado brasileiro ajudara.

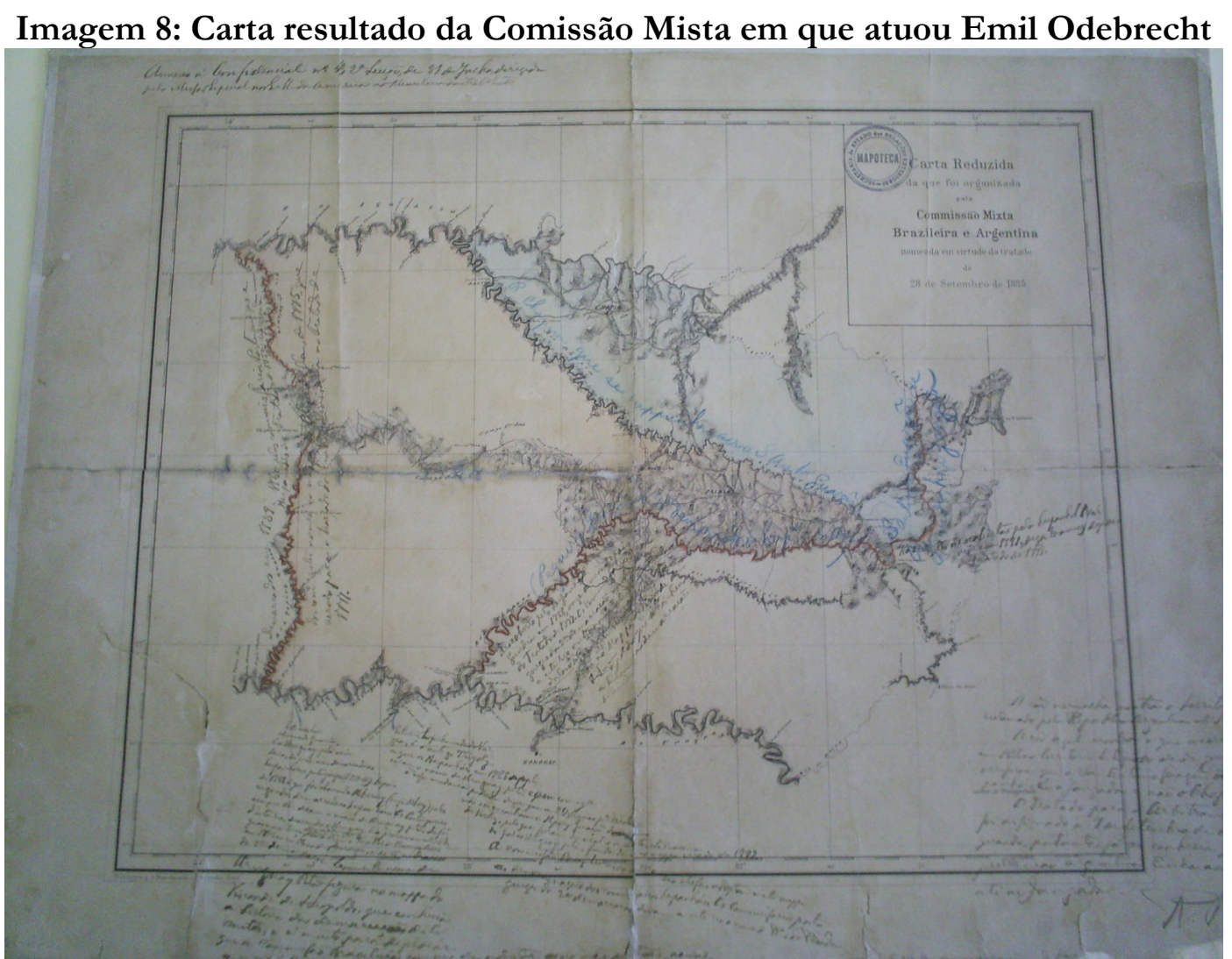

Anotações e estudos (provavelmente) realizados pelo Barão do Rio Branco. Carta produzida no II Império (Uma das imagens utilizadas no estudo preparatório para elaborar defesa do Brasil).

Disponível do acervo da Mapoteca do Arquivo Histórico do Itamaraty no Rio de Janeiro

Emil soube utilizar em seu favor, capitalizar, o resultado de suas entradas ao Oeste, atuando no papel de ajudar legitimar a localização de onde era Brasil e diminuir as incertezas. O resultado material de seus trabalhos, além da cartografia como se percebe na imagem anterior ( $\left.n^{\circ} 8\right)$, está também em facilitar algumas colocações para seus filhos, como no caso do mais velho ter se tornado funcionário dos Telégrafos na capital do Império. Será somente o filho mais novo o único da prole do casal a ter 
frequentado universidade. Para alguns dos demais, o capital simbólico, os contatos das redes de relacionamentos aberta com sua função de atuar em levantamento de área, abriu outras portas. Além do capital simbólico, ir progressivamente aumentando com suas incursões e levantamento de informações ao interior, o capital social (os saberes formais) aos quais portam os indivíduos, influenciam na desigual distribuição dos poderes. Talvez, por ir acumulando no Oeste (da selva ao espaço em litígio como foi percebendo ser Emil uma situação favorável a ele), o simbólico de auxilio em seus saberes ajudarem no manter o território do Brasil, Emil em carta para esposa recomenda que ela continue a manter os filhos na escola. É dessa gramática do campo escolar o aprimoramento do capital social. O engenheiro cristalizava os capitais simbólicos, pois em País em que a manutenção de área é sagrada, quem apoia essa conquista, sacralizado também se torna.

\section{Olhando e temendo a vizinhança. Valores da área em litígio: natureza e território}

No arquivo de documentação do Acervo do Itamaraty no Rio de Janeiro estão separados alguns documentos, divididos em ordem de Países que fazem fronteira com o Brasil. Segundo pode-se discutir de algumas dessas documentações disponíveis na "Pasta Limites" no Setor Argentina, o Império brasileiro parece ter estado atento, com agentes monitorando o que se passava no território argentino, principalmente ao departamento fronteiriço ao litígio de Palmas. O Brasil colocava certa atenção no caso, acompanhando e produzindo relatórios a respeito da área. Sobre a federalização de Misiones, quando colocou um governante (ou seja, transferência de domínio provincial para o nacional) pela república Argentina, por exemplo, eram informações observadas pelo Brasil e descritas nos relatórios produzidos. Segundo relato destacado pelo secretário do Itamaraty em "[...] março de 1881 um decreto dividiu em cinco departamentos o território de Missões”. (BARÃO DO CABO FRIO, 11/II/1889).

Para compreender a dinâmica territorial argentina, se deve levar em conta outros fatores do que, apenas, ter espaço fronteiriço com o Brasil e área de disputa entre os dois Países. Como explica sinteticamente a pesquisa de Bruno Aranha (2014, p.52), a federalização de Misiones também está relacionada ao processo de tornar Buenos Aires uma influente capital da Argentina. Junto de uma geopolítica internacional, há também o processo interno argentino a ser mencionado:

Após o fim da Guerra do Paraguai em 1870, Misiones foi formalmente integrada à província de Corrientes. No entanto, o objetivo do governo central de Buenos Aires de colocar essa região estratégica de fronteira sob seu domínio 
direto resultou no decreto da federalização desse território em 1881, criando assim o Território Nacional de Misiones, ainda que sob protesto de Corrientes que perdia uma parte importante de seu território. (ARANHA, 2014, p.51-52).

A resposta do Império brasileiro, sob a política vizinha, foi criar duas colônias militares na área de Palmas, mas fora da área de "dúvida" stricto sensu. Como representado nas imagens (ver mapas $\mathrm{n}^{\circ} 4$ e o da próxima página, $\mathrm{n}^{\circ} 7$ ), produzidas agora na "atualidade" como maneira de visualizar tanto a área em disputa, como a sede das colônias militares fundadas pelo Brasil na década de oitenta dos oitocentos. Desde ao menos a segunda metade do século XIX, ocorria ruídos e tentativas de diálogos entre os Países para reconhecimento da área, mas a partir de 1881 e até mais cinco anos após a derrubada da Monarquia, será no ano de 1895 que ocorrerá o resultado final.
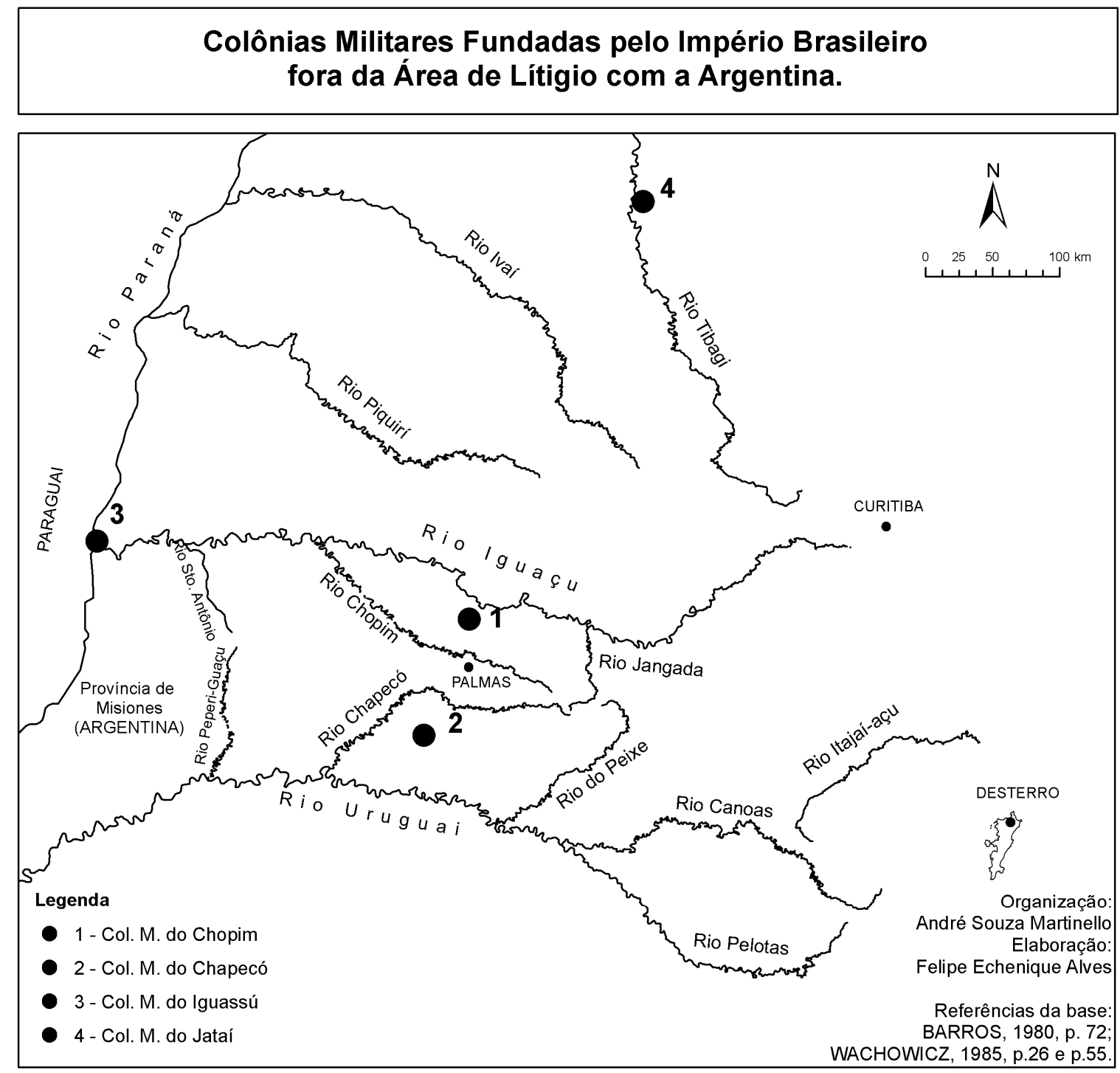

Imagem nº. A partir de 1888 a Colônia Militar de Chopim será vista como dentro do litígio, pois, Argentina ampliou área de reinvindicação, colocando-se até o rio Jangada. 
No ano de 1859 é baixado decreto Imperial ( $n^{\circ}$ 2502) para criação de duas colônias militares, nos rios Chopim e Chapecó, mas são efetivamente fundadas mais de duas décadas depois, em 1881. Segundo a interpretação de Juca Paranhos, sabendo pela imprensa do estabelecimento de tais núcleos militares, a Argentina passa claramente, a não reconhecer a posse brasileira e então, tratá-la como em litígio.

Teve [a criação das duas colônias militares], porém, o efeito de revelar que a República Argentina já não se limitava, como em 1876, a manifestar dúvidas sobre a exata posição dos rios Pepiri-Guaçu e Santo Antônio. Pela primeira vez um seu representante oficial, dirigindo-se ao governo brasileiro, considerava litigioso o território a leste desses dois rios e assinalava como limite oriental da pretensão argentina os rios Chapecó e Chopim. (RIO BRANCO, 2012, p.238). (destaques meus).

A partir das trocas de algumas correspondências entre Argentina e Brasil ao longo do tempo é possível observar, como os diálogos e debates às vezes eram tensos. $\mathrm{O}$ ainda Barão do Cabo Frio, cujo título nobiliárquico de Visconde recebeu em maio de 1889, certa vez afirmou ao governo do País platino - em fevereiro de 1889 - como não havia sido fundada nenhuma Colônia Militar do Império na área (ou sobre ela) em litígio, como reclamava o governo argentino, e sim, bradava Cabo Frio, em lugares que não eram nem reivindicados pela argentina, o caso das Colônias Militares de Chapecó e Chopim. ${ }^{96}$ Embora, a Argentina ao passar a ampliação da área total considerada em litígio (ver imagem $\mathrm{n}^{\circ} 7$, na página anterior), coloca reivindicação da área que ia até $\mathrm{o}$ Rio Chopim, a partir de 1888, passa a ser mais, até o Rio Jangada.

$\mathrm{Na}$ opinião de um autor brasileiro, que no século $\mathrm{XX}$ fez um estudo panorâmico do histórico litigioso, a estratégia da Argentina para não perder seu Estado de Misiones, caso viesse o Brasil algum dia reivindicá-lo foi - como uma espécie de contrapartida desejar adentrar em área brasileira, assumindo como sua a área. Embora bastante ensaístico e sem mencionar base documental, Ruy C. Wachowicz (1985) defendeu a ideia da questão de Palmas como um grande blefe diplomático, pois para ele "Na prática, o grande objetivo geo-político da Argentina era conservar argentino o território de Misiones." (WACHOWICZ, 1985, p.51). Mas, é importante dizer, as estratégias e dissimulações aconteciam internamente e externamente às duas nações. Houve

\footnotetext{
${ }^{96}$ Ainda antes da República em comunicado que parece ter sido enviado ao governo argentino (ou representante do mesmo) o Barão, três meses depois tornado Visconde do Cabo Frio, assinou o áspero dizer: "[...] peço licença para assegurar Sua Excelência que não está bem informado quando diz que as colônias militares subsistem e se aumentam apesar da declaração feita ao Sr. Dominguez. Essas colônias são fundadas, na margem esquerda do rio Chapecó e na direita do Chopim, isto é, em território reconhecidamente brasileiro, fora do que se acha em litígio entre os dois países." (BARÃO CABO FRIO, 11/02/1889) Documento Lata 443, maço 11 do Arquivo do Itamaraty, no Rio de Janeiro.
} 
momentos, em que se se chegou a pensar mais na resolução em guerra, do que na política de chancelaria. Talvez Wachowicz, quisesse ter dito como a Argentina temia o Brasil reivindicar algo ou parte da sua província de Misiones, principalmente pelo apoio das forças brasileiras nessa área argentina durante a Guerra do Paraguai; mas, não foi o que Wachowicz disse e, sua interpretação, não apresenta base documental alguma.

Paranhos Júnior, o Juca (futuro Barão do Rio Branco), em carta privada no começo da década de 1880, deixa claro sua preocupação beligerante e sobre as forças armadas brasileiras, das consequências de eventual entrada em conflito aberto. Como afirma Luís C. Villafañe G. Santos (2012, p.69), mesmo vivendo em Paris ou Liverpool, Paranhos Jr. mantinha-se ao que ocorria na região do Rio da Prata. Chegou a acreditar como, desde o início do Império, essa era a vez de maior situação de vulnerabilidade:

[Paranhos Júnior] Manteve aceso seu interesse por essas questões e, em especial, tinha viva a memória das negociações de seu pai, em que atuou como secretário. Assim, por exemplo, em 1882, escreveu ao barão Homem de Melo sobre a fronteira ainda indefinida com a Argentina:

Fico muito inquieto com nosso negócio de Missões, porque se os argentinos aproveitarem a ocasião teremos de passar por grandes vergonhas. Não temos esquadras, não temos torpedos, não temos exército, e os argentinos tem tudo isso. Pela primeira vez, desde que o Império existe, achamo-nos assim à mercê dos nossos vizinhos [...] (SANTOS, 2012, p.70)

Rio Branco foi um regular estudioso de variadas questões da região do rio da Prata e tendo também, bastante interesses nas forças armadas e situação militar do Brasil; parece ter tido uma opinião bastante pessimista, quanto ao preparo brasileiro em eventual declaração de guerra contra argentina. O importante a sublinhar é sido aventada tal possibilidade de confronto aberto. Fiz essa menção e citei a opinião de Juca Paranhos, apenas para apontar como foi à guerra uma possibilidade sugerida de ocorrer.

Quero encerrar esse tópico, discutindo trechos de dois documentos sob a guarda da Biblioteca do Arquivo Histórico do Itamaraty (Rio de Janeiro). Um do ano de 1892 intitulado: $O$ tribunal arbitral, cujo autor menciona ser diplomata e oficial da Marinha, Henrique C. R. Lisboa (cuja algumas passagens de seu texto mencionei anteriormente) e, a publicação em 1895, chamada: A propósito da Questão Missões de Alcides Cruz.

Para Henrique C. R. Lisboa (1892), as principais justificativas do Brasil em manter seus interesses na promoção de uma firme política de manutenção da área em litígio, estava em algumas características intrínsecas à região, entre elas, à riqueza natural. A dúvida de quem iria pertencer o espaço na disputa Brasil versus Argentina, parecia prorrogar a consolidação de apropriação contínua. Afirma ideia, como se a 
própria natureza desejasse pôr fim à dúvida (do litígio), pois a não certeza dificultava o acesso aos recursos da área de Palmas “[...] cujo exuberante natureza só almeja o fím desta disputada de trinta anos, para prodigiar, em beneficio geral, tesouros acumulados." (LISBOA, 1892, p.31). (destaques feitos por mim).

Uma concepção bastante semelhante de uma poupança guardada pela natureza aparece também, na qualificação da região feita por Alcides Cruz (1895, p.14) quando menciona a existência e possibilidade de "produtos de exploração mais lucrativa", como a erva-mate, mandioca, batata, trigo, milho, algodão, feijão, centeio e "multidão de plantas têxteis". Mas além de uma riqueza da diversidade da flora, Cruz (1895) aponta suposta vantagem climática ${ }^{97}$ pela não localização em "latitude tórrida". Não sendo nem área de frio ou inverno intenso, nem calor concebido de maneira bastante pejorativa: "quanto ao clima pode-se dizer, sem reservas, que é o melhor do sul do Brasil; nas margens do [rio] Uruguai não há neves, nem tampouco o calor tem a africana intensidade do de, Santos ou Rio [de Janeiro]." (CRUZ, 1895, p.14-15).

Do ponto de vista estratégico, a perda da área significaria também, uma vulnerabilidade de comunicação, acesso e contato com a Província do Rio Grande do Sul. Essa é inclusive, uma das preocupações mais centrais e recorrentes na defesa de Palmas ao Brasil em várias opiniões e autores, embora seja mencionado Santa Catarina, quase sempre a ênfase atribuída à região de Palmas é mantendo-a, facilita conservar o Rio Grande do Sul como parte do Brasil. Perdendo Palmas, o extremo meridional brasileiro estaria vulnerável em segurança na defesa de manter essa parte do País, o que ficaria menos conectada. Essa mesma argumentação irá aparecer também no dossiê de 1894, assinado pelo Barão do Rio Branco (2012), no qual diz ser Palmas, vital para mantar ligação terrestre com Rio Grande. “[...] a posição especial desse território, que lhe é indispensável para a sua segurança e defesa e para a conservação das

\footnotetext{
${ }^{97}$ Mobilizar o clima (ou fatores climáticos) como particularidade positiva de espaços do sul do Brasil, tomam evidência e emergem em discursos no século XIX, delimitando áreas especificas. A ideia de clima não tropical ou menos ligado às representações feitas às zonas tórridas, reverbera em um tipo de regionalismo (e particularismo vinculado à Europa e) mais propício à adaptação de europeus em solo brasileiro, considerando menos salubre. Para Marlon Salomon (2005) o clima (somado a imigração) foi uma das representações na invenção do Sul do Brasil no século XIX. Hermann Blumenau, por exemplo, indicou áreas de Planalto como aclimatação saudável aos alemães, em uma perspectiva determinista: "No planalto das regiões do sul do Brasil, partindo da Serra do Grão Mongol (Lat.16-17 S. Br.) na Província de Minas Gerais até a fronteira oeste da Província do Rio Grande do Sul e Santa Catarina, encontra-se uma ou duas embocaduras de rios com mangues e alguns lugares de vales cerrados. Até mesmo o clima da faixa litorânea do Rio de Janeiro e São Paulo perde sua inospitalidade assim que se chega nas encostas das montanhas, que estão entre 2 e 10 léguas do litoral, sendo que nesta região vivem muitas famílias alemães cujo estado de saúde nada deixa a desejar.” (BLUMENAU, Apud SALOMON, 2005, p.104).
} 
comunicações interiores entre o Rio Grande do Sul e os outros Estados da União Brasileira." (RIO BRANCO, 2012, p.68).

Henrique C. R. Lisboa (1892) destaca como a existência de uma cunha argentina em território brasileiro seria desfavorável na manutenção de integração (e coesão) com uma área de tradição de rebeldia e autonomia. ${ }^{98}$ Mais uma vez, é um exemplo da centralidade da noção de espaço, como análise do Brasil: o seu território. Perder essa parte do Oeste de Santa Catarina e do Paraná para a Argentina seria, segundo o autor cujo texto é datado pela época da revolta Federalista, uma verdadeira ameaçada e vulnerabilidade militar devido a consequente menor contiguidade entre Rio Grande do Sul e o Brasil. Nas palavras de Henrique C. R. Lisboa (1892, p.28), se a Argentina ganhasse tal espaço, parte do Brasil sofreria risco de divisão (destaques sublinhados a seguir, feitos por mim).

Efetivamente, suposta adquirida pela República Argentina a fronteira que ela pretende, penetraria o seu domínio até o coração dos estados meridionais do Brasil, segregando quase, pela aproximação desse domínio às praias do Atlântico, o Rio Grande do Sul e Santa Catarina do resto da União. Considerada a situação relativa das suas nações sob o ponto de visto estratégico, é evidente a ameaça resultante de tal domínio. (LISBOA, 1892, p.28).

Já no texto de Alcides Cruz (1895), a interpretação feita é da influência do tamanho das propriedades rurais, chamando atenção para a ideia do tamanho da apropriação de terra gerar resultados sociais diferentes, se comparado com as grandes propriedades. Para ele, "a pequena lavoura na cultura da pequena propriedade" torna agricultores mais vinculados a terra, pois, da parcela do solo sabem tirar sustento, dando em consequência, inestimável valor. $\mathrm{O}$ estilo de apropriação em fracionamento da terra em lotes, o autor propõe o Estado brasileiro realizar na área de litígio, pois essa maneira de colonização significaria maior capacidade de industrialização. Da pequena propriedade "é que deve surgir o futuro tipo industrial das sociedades." (CRUZ, 1895, p.15).

\footnotetext{
${ }^{98} \mathrm{O}$ uso de autonomia em relação ao poder metropolitano, constituiu uma característica marcante na dimensão política da história territorial da Capitania (e depois Província) de São Pedro do Rio Grande do Sul, como caracteriza Helga I. L. Piccolo (2005, p.78): "Com a apropriação de terras e organização econômica e social do território apropriado, constitui-se, na capitania de São Pedro, um poder privado que se fortaleceu, agindo com muita autonomia, demonstrando capacidade de arregimentar "gente" para a defesa desse território, o que significou defender as terras integradas ao seu patrimônio pessoal. Esse poder privado seria instrumentalizado pelo Estado português, incapaz de, com seus efetivos militares, assumir a defesa do território que lhe interessava por razões geoestratégicas e econômicas, em face das pretensões do Estado espanhol sobre a região platina. Ao não lhe ser possível prescindir do poder privado, personificado nos chamados "senhores guerreiros", o Estado português tolerou a sua autonomia de ação. E este autonomismo, como princípio de vida e de ação, foi (e sempre seria) reivindicado e defendido pelos proprietários de terra, ou seja, a elite estanceira." (PICCOLO, 2005, p.78). (destaques meus).
} 
Uma sugestão preferencial de projeto (e destino) à área confirmada do Brasil, seria torná-la semelhante aos núcleos de colonização de imigrantes europeus que o Império vinha fazendo em partes florestais do sul do Brasil, pois em uma lógica parecendo em processo desencadeador, ajudaria na valorização daquele espaço. "A aglomeração de famílias, dá nascimentos ao povoado, o povoado eleva-se a cidade. As cidades ligam, cooperando reciprocamente para a expansão comercial que começa a florescer, o capital associa-se, circula largamente e a nação está com sua riqueza garantida.” (CRUZ, 1895, p.16).

Antes de encerrar o presente capítulo no qual problematizarei alguns usos do território (já passamos por republicanos, por Emil Odebrecht e pela geopolítica da Monarquia desejando conhecer melhor o espaço), considero pertinente também, para evitar confusão, reforçar como a área própria da Argentina contigua ao litígio (o território do seu País, da nação argentina) tinha como nome do Departamento - a certa altura da história argentina, federalizado - chamado Misiones. Usavam do mesmo nome para seu Departamento e para área de litígio com clara estratégia para buscar legitimidade por continuidade. A resposta do Império brasileiro, sob a política vizinha, foi criar duas colônias militares na área de Palmas, mas fora do litígio stricto sensu. Como representado nas imagens anteriores (ver mapas $\mathrm{n}^{\circ} 4$ e o $\mathrm{n}^{\circ} 7$ ), produzidas "agora na atualidade" como maneira de visualizar didaticamente tanto a área em disputa, como a sede das colônias militares fundadas pelo Brasil, na década de oitenta dos oitocentos.

Tendo discutido alguns atributos ao espaço, sigo no tópico a seguir, mais especificamente a figura de um monarquista servindo à República. A aproximação do Barão com republicanos acontece a partir do momento em que ele - Rio Branco - é colocado dentro do processo de elaboração, como o autor do laudo brasileiro sobre o litígio, atuando na elaboração de um dossiê para garantir a posse da área ao Brasil. Chegamos no defensor representante do Brasil na Arbitragem.

A vitória (foi) dos mapas e do Barão do Rio Branco: trajetórias e contexto do "herói territorial" nacional, por excelência

O nome podia mudar e mudou de lugar, mas o lugar ficou onde estava (Barão do Rio Branco, 2012 [1ªed: 1894], p.168)

Nada mais rotineiro e esperado de tratar a relação de litígio de uma área em reivindicação por duas nações, pela discussão da fronteira. Evidente. Ainda mais em uma pesquisa no campo da Geografia, junto do caso das duas nações possuírem linhas 
de limites entre si. Bons estudos já fizeram esse recorte e diálogo pela fronteira e não tenho a pretensão de questioná-los aqui, mas, sim, dialogar. Não escapo da discussão, embora não seja propriamente a maior ênfase. Exemplos de muito boas pesquisas feitas das - embora seus autores não chamem assim, eu entendo o litígio como - lutas pelo direito de governar; as pesquisas de Maristela Ferrari (2010), originada de uma tese de doutoramento em Geografia da Universidade Federal de Santa Catarina-UFSC, assim como a de Adelar Heinsfeld (1996), originalmente uma dissertação de mestrado em História na Pontifícia Universidade Católica do Rio Grande do Sul-PUC/RS. Ambos trabalhos acadêmicos publicados em livros por editoras universitárias. Por sua vez, o trabalho de Ruy C. Wachowicz (1985) é de uma época em que não se demandava uma visão menos etnocrêntrica ou (auto)crítica, sendo o mesmo mais engajado por se posicionar favorável à sua própria nação e com rotineira desconfiança da política argentina, sem algum refinamento teórico, nem base documental. Usei a obra desse autor ou em diálogo com ele, apontando possíveis limitações que consegui identificar.

A partir do conhecimento de alguns documentos da época e da revisão de literatura sobre o tema, considero uma espécie de adesão, ou "permissão" da Argentina e do Brasil a uma verticalidade ${ }^{99}$ ao possibilitarem a decisão, chamada a vir de outro ponto que não de seus territórios (decisão de fora desses dois Países), a quem iria corresponder, de fato, a tal área. Está relativamente bem coberta nesses estudos recentes a discussão do litígio, embora eu tenha usado de documentação diversa da literatura produzida até então, para, a partir de pesquisa documental, colocar outras questões. Por isso, meu diálogo com os estudos já realizados vai menos pelo caráter da geopolítica quase sempre o melhor campo ao qual se inserem - e mais pela discussão da história territorial, particularmente, discursos de legitimidade de apropriação. Da literatura de análise da conquista, posse, apropriação e representação dos espaços, no sub-campo da formação territorial, como entende Antonio Carlos R. Moraes (2000; 2005; 2009). Reflexões, na qual parte de proposições desse autor são tributárias em diferentes trechos dessa pesquisa. Na discussão a seguir, somo diálogo e em revisão de literatura com pesquisas produzidas a respeito do Barão do Rio Branco.

\footnotetext{
${ }^{99}$ Relembro aqui uma das tão férteis e boas discussões realizadas por Milton Santos (2002, p.245) a partir de Lênin, que penso, não deveríamos esquecer: “[...] as relações verticais nos indicam as relações de uma sociedade com as outras sociedades." (SANTOS, 2002, p.245). Em poucas palavras, a verticalidade pode ser entendida como uma abrangência de um território a ser governado, sofrer alterações ou receber ordens vindas de uma escala distante dele próprio. Um ponto do território influenciado/controlado por outro, em uma relação nem sempre tão evidente ou perceptível.
} 
Luiz C. Villafañe G. Santos (2012, p.10), chama atenção para o fato do tratamento de Barão do Rio Branco, como um dos símbolos fundadores da nação brasileira parecer deslocado no tempo. Não sendo mera curiosidade, pois, - lembra o autor do ótimo livro O evangelho do Barão, Rio Branco e a identidade brasileira trata-se, de um dos founding fathers (heróis fundadores, "pais da nação") que não viveu no momento da Independência em 1822, afinal, nem havia nascido ainda, vindo ao mundo posteriormente, em 1845. O mesmo autor afirma costumar termos em Rio Branco, um dos importantes sujeitos na consolidação do nacionalismo, como esteio ideológico do Estado brasileiro, um dos santos nacionais (SANTOS, 2012, p.13). A República Velha ao qual também atuou - como ministro das Relações Exteriores entre os anos de 1902 até 1912 - representa a estabilização da nova ordem oligárquica.

Na busca de conciliação, consenso e apresentação de política externa como manutenção contínua e linear, sem promover ideia de ruptura, a cabeça de um monarquista convicto teria auxiliado no lançamento de "base para concepções políticas" da forma do Brasil fazer sua inserção no mundo. Alguns acreditam a simplória concepção da Relação Exterior brasileira, como se independente da política interna, sendo uma tradição originada com o Barão e perpetuada até hoje, em diversos discursos.

Interessa aqui, principalmente, focar nos momentos antes de Rio Branco tornarse ministro, função ao qual tomou posse aproximadamente treze anos após a proclamação republicana, ficando uma década em poderoso cargo, quando faleceu. Como tratei na primeira parte (nos tópicos anteriores) do presente capítulo, a respeito de algumas atribuições dadas ao espaço e, da busca de uso do mesmo como as intenções e mobilizações discursivas do litígio entre Argentina e Brasil, agora proponho não focar necessariamente no contexto desse resultado. Relativamente, continuo sem focar apenas nas discussões envolvendo, a primeira resolução de litígio de divisa e fronteira ocorrido na República. Sendo também, primeiro dos acordos fronteiriços e processo de legitimação de posse de terreno dos quais participou Barão do Rio Branco, acontecimento público a possibilitar visibilidade a ele próprio. "Rio Branco, inclusive, só alcançou notoriedade muito depois, quando se divulgou o laudo sobre o território de Palmas. A partir daí, Rio Branco experimentou uma intensa atividade política, até sua morte, em 1912.” (SANTOS, 2012, p.126).

Inclusive o resultado dessa vitória ao Brasil na arbitragem, segundo as memórias do filho mais velho do Barão, o embaixador Raul de Rio Branco (1942, p.19), foi 
literalmente um divisor de água na vida de seu pai ${ }^{100}$ o antes e o depois da arbitragem dos EUA é marcante na vida do Barão. Sem dúvida, a decisão do presidente dos EUA, passa o autor do dossiê do Brasil, a ser mais conhecido entre os brasileiros. No mesmo ano do resultado final do litígio, em obra intitulada A Propósito da Questão Missões, Alcides Cruz (1895) mencionou - diretamente - o Barão como sendo filho de gente ilustre e de um certo alguém - do Visconde -. "O Barão do Rio Branco, filho de um homem que muito se elevou na vida pública, herdou as qualidades paternas." (CRUZ, 1895, p.16).

Da mesma forma afirmou Rubens Ricupero (2000, p.07); até o voto de arbitragem dos limites por Cleveland, Rio Branco não se destacava publicamente, sendo ele mais conhecido como um reflexo das ações paternas, como também escreveu Joaquim Nabuco à época, no editorial do Jornal do Comércio em nove de fevereiro de 1895. (RICUPERO, 2000, p.11). Personagem até então de menor aparência, o resultado do laudo do presidente estadunidense, parece ter sido um momento fundamental do lançar o Barão nos holofotes da esfera pública. Vindo de um alto cargo de indicação política na burocracia consular, segundo afirma Francisco Doratioto (2012, p. 34): "Foi na realidade, o primeiro personagem pública da era republicana a conquistar a nação." É consenso entre seus biógrafos como se "Demorou em se fazer notar, só alcançando o primeiro grande sucesso aos cinqüenta anos, na questão de Palmas ou das Missões." (RICUPERO, 2000, p.07).

Das questões de fronteiras do Brasil, a Monarquia tinha resolvido duas delas, com o Uruguai e com o Paraguai; a primeira (com a Argentina) na República, o Barão conseguiu capitalizar muito do resultado favorável, para si próprio.

\section{Do Visconde para o Barão: o sucesso, de pai pra filho}

Barão do Rio Branco é considerado um dos ministros mais longínquos à frente da pasta das Relações Exteriores, cargo de alta confiança exercido durante o mandato de quatro consecutivos diferentes presidentes da República (quais sejam: Rodrigues Alves, Afonso Pena, Nilo Peçanha e Hermes da Fonseca). Seu pai, o Visconde de Rio Branco (1819-1880) também é referenciado como o gabinete mais duradouro do Império. Com recorde de quatro anos (entre 1871 até 1875) constantes na chefia - do conselho geral de demais ministros e de toda governança no Segundo Império (BARMAN, 2012,

\footnotetext{
100 “[...] é preciso considerar que a vida do Barão do Rio Branco se divide em dois períodos distintos: o que precede a missão arbitral de Washington (1893) e o que veio depois." (RIO-BRANCO, 1943, p.19).
} 
p.355), no mais alto dos postos abaixo do Imperador. Visconde foi ministro da Marinha, três vezes ministro dos Negócios Estrangeiros, Ministro da Fazenda, ocupou diversos cargos de relevo no Império e a partir de 1862, escolhido Senador vitalício por Mato Grosso. (SANTOS, 2012, p.62-63).

Defendo a existência da profunda influência de Visconde na bem-sucedida vida política ou pública do Barão. Para compreender circunstância decisivas de trajetórias, da ascensão, das escolhas e mesmo do posicionamento nacionalista, e entre outros, político e ideológico do filho, Paranhos Júnior - o Juca - é preciso relacioná-lo ou compreendêlo em paralelo às trajetórias do Paranhos, pai. Exercício, aliás, que não farei aqui em seu conjunto maior esgotando-o (até porque outros autores já se detiveram a isso), mas, sim, relacionando pontualmente influências do Visconde em ganho de possibilidades ao Barão, favorecendo Paranhos Júnior tornar-se uma autoridade e personalidade pública.

Em parte, de maneira não determinante, Barão parece ter se percebido na larga influência paterna sobre sua vida e ele mesmo reconheceu a forte direção de seu pai, segundo aparece no relato das reminiscências do filho do Barão. Raul do Rio-Branco (1942, p.11) escreveu que seu pai (a)creditava “[...] que a educação, não apenas do professor mas principalmente da família decide do futuro. Por isso, ele [Barão] tinha imensa pena dos órfãos, privados na sua meninice dos conselhos e sobretudo dos exemplos que nos orientam na vida." (RIO-BRANCO, 1942, p.11). Houve uma espécie de circulação de saberes, de uma educação informal, que o Barão atingiu pela vida privada. Viveu uma super estimulação na experiência direta, conhecendo in loco tanto os ambientes históricos de disputas como o Rio da Prata, assim como personalidades políticas, diretamente envolvidas no topo da administração do Estado brasileiro.

Já entenderam o Barão como diplomata, jornalista, geopolítico, geógrafo, historiador etc. (BECKHEUSER, 1943; HEINSFELD, 2000; MORAES, 2012), tal literatura está bem adensada e não busco contradizê-la. É certo ter sido um erudito de seu tempo, resultado também por influência direta do capital cultural, social e político herdado na socialização ${ }^{101} \mathrm{com}$ seu pai e o imediato meio - inclusive intelectual -

\footnotetext{
${ }^{101}$ Nas palavras do memorial escrito pelo primogênito Raul do Rio-Branco (1942, p.42): "Foi nessa época [da Guerra do Paraguai] que meu Pai começou a colecionar plantas e mapas das regiões, fotografias dos campos de batalha e toda sorte de informações a respeito da guerra, quer diretamente, quer por meio de relações que foi estabelecendo com personalidades notáveis como o Duque de Caxias, o General Andrade Neves, o General Osório, o brigadeiro Antonio da Silva Paranhos, seu tio, Floriano Peixoto e Pires Ferreira, então jovens oficiais de terra, os almirantes Silveira da Mota, Saldanha da Gama, Custodio de Melo, Wandenkolk, Maurití, então jovens oficiais do mar, alguns dos quais mortos no campo [...]."
} 
permitido de vivenciar. Segundo registrou um de seus filhos: “[...] meu Pai se encontrava com os homens notáveis da época." (RIO-BRANCO, 1942, p.60)

Sabe-se do interesse, paixão e dedicação do Barão pela história militar do País; como pesquisador, autor e pensador engajado em formulações de narrativas dando sentido ao passado do Brasil, particularmente de uma geração romântica, ao qual pertenceu. Várias figuras-chave e membros da alta patente na Guerra da Tríplice Aliança contra o Paraguai, colegas de Visconde, foram do convívio na juventude de Juca. Dentro da sua casa, pode escutar relatos da vida política do País, em diálogos entre autoridades ao grupo (Partido Conservador) qual pertencia Paranhos, pai.

Barão inspirou-se e teve como fonte de informações, muitas figuras ilustres que estiveram em acontecimentos do qual ele tornava-se autor de textos. ${ }^{102}$ Preocupado em defender o que considerava pertinente evitar com que se caísse no esquecimento, algumas batalhas, vitórias e realizações conformadoras de uma grande nação. Entre as histórias de grandeza da pátria, estaria àquele fio condutor explicativo de conseguir manter unida, proporção elevada de uma mesma área e a continuidade de governança sem quebras de radicalidades (como se apenas essas lavassem à fragmentação territorial). Uma ideia de harmonia política, com domínio de vasta área continental. Essas foram uma das justificativas pela sua elevada admiração de Pedro II, por exemplo. A escravidão vista como um atraso era uma das críticas, na história de um dos últimos países a ter fim ao trabalho compulsório; algo degradante e na afirmação de Raul de Rio-Branco (1942, p.58) sustentador "da ociosidade nas classes superiores."

O cognominado comum em uma sociedade de mercês como o Império do Brasil, ao promulgar ou conceder algum título de nobreza, também poderia acompanhar quase sempre um novo nome a ser incorporado ao de batismo ou do nome formal de registro. Rio Branco, vem de um topônimo localizado na então Província do Mato Grosso, por onde Paranhos era Senador e conseguira com que seu filho mais velho fosse eleito, pela primeira vez candidato, deputado representante por essa Província, sem nem necessitar a presença física de Paranhos Júnior por aquelas paragens. Elegeu-se deputado vivendo no Rio de Janeiro e sem sair da capital para fazer campanha. O nome recebido com título pelo pai, Visconde de Rio Branco, marcante por ter como referência uma circunstância de área em disputa, como explicou Cristina P. de Moura (2003, p.30):

\footnotetext{
${ }^{102}$ Por exemplo: "Foi nesse ano de 1876 que meu Pai publicou em dois volumes os comentários à história da guerra da Tríplice Aliança, obra cujo texto original fora escrito em alemão por Schneider, leitor do Rei da Prússia, depois Imperador da Alemanha, Guilherme I.” (RIO-BRANCO, 1942, p.64).
} 
"Rio Branco era o nome de um pequeno rio ao sul do Mato Grosso, onde o Paraguai desejara fixar a fronteira com o Brasil, em vez do Rio Apa, onde Paranhos conseguiu estabelecer os limites, com mais vantagens para o seu país". O lugar deu nome a pessoa.

Sendo esse mais um caso de título nobiliárquico no Brasil em que a toponímia passou a ser usado para nome de gente, algo comum na sociedade monárquica brasileira do século XIX. E não deixa de ser uma toponímia ligada à vitória do território, do resguardo do mesmo. A relação de influência, destaque ou vinculação de determinada figura política com alguns lugares tendeu influenciar ao nome - muitas das expressões originados em línguas indígenas - que acompanhavam ao título de nobreza. Não seria mero acaso um topônimo vir da Província por onde o político era Senador; sua influência no Mato Grosso, seu papel na região desde a Guerra do Paraguai e demais questões do Prata, informa o recebimento da alcunha de Rio Branco com o título do nome de um curso de água em área fronteiriça.

É comum aparecer em certa literatura de epopéia biográfica, um posicionamento tratando a vida do Barão do Rio Branco como um líder nato ao estilo self made man. Excessivamente elogiosa como fez, por exemplo, o seu filho Raul de Rio-Branco (1942) em livro intitulado Reminiscência do Barão do Rio Branco, obra cujo embaixador e primogênito afirmou relatar, via sua memória de filho do Barão e neto - segundo apontam biógrafos, nunca tendo se conhecido neto e avó - do Visconde, obra que começara a escrever vinte anos após a morte de seu pai Juca, o Paranhos Júnior. Já mais recentemente, um pequeno ensaio de Rubens Ricupero (2000), também apresenta uma concepção elogiosa e bastante liberal de um - parece até ironia, Barão - que se fez por si mesmo. Ricupero (2000), pouco enfatiza as indicações, habilitações e mesmo algumas possibilidades viabilizadas por ser Barão herdeiro de uma figura ilustre do Império.

Segundo esse mesmo autor explica a trajetória de Rio Branco, como um feliz desencadeador de boas oportunidades, interpretação com a qual não concordo pela aparência frágil, mas principalmente por evitar tratar ou mesmo silenciar de aspectos (aparentemente) "menos" ilustres. Uma afirmativa como a seguir, é realizada como se não existisse àquelas práticas personalistas de uma sociedade de compadrio e do favor: "É a história de uma ascensão [a do Barão] conquistada graças a esforços e resultados, passo a passo, e legitimada por êxitos adicionais, sem favorecimentos, na linha da frase norte-americana 'nada como ter o sucesso para ter sucesso'." (RICUPERO, 2000, p.24). Definitivamente, se essa linha estadunidense ocorre, não parece caso do Brasil. 
Não considero efetiva a ideia de não favorecimentos para caminhos seguidos por Rio Branco, a começar pelo título nobiliárquico de Barão recebido em 1888 e depois sua recusa de evitar usá-lo como desejavam alguns republicanos pós-novembro de 1889. Penso que aqui, não cabe deixar de apontar os pontos em que ser filho de um Visconde foi muito favorável e usado pelo próprio Barão em uma sociedade nobiliárquica e em seguida, na República. Há quem pareça evitar lembrar dos favores ou indicações como se "estragasse" ou diminuísse a biografia do biografado.

Se considerarmos não sermos salvadores de biografias, mas interessados em entender sociedades/pessoas em suas respectivas épocas e mobilidades é pertinente associação com uma literatura crítica social, tal como àquela produzida por Pierre Bourdieu (1996). Esse autor ao apontar as ascensões em redes de sociabilidades, nas formas de decifrar códigos e símbolos sociais como uma das formas de desnaturalizar a ideia de trajetória bem-sucedida e individual.

O capital social portado por indivíduos, informam muito de suas capacidades de sucessos e "fracassos". A recusa, portanto, de tratamento heróico se faz ao apontar em quais redes (se) sustentam algum personagem, evitando uma ilusão biográfica. Não há heróis que resistam as redes e cultura que os suportam. ${ }^{103}$

Encontrando situações de contatos, preferências, escolhas, pressões, vínculos e capacidades habilitadas, distribuídas desigualmente nas relações de poderes em uma sociedade, passamos a recusar a ver os movimentos das pessoas como genialidades, líderes natos ou mais simploriamente, pré-determinados. Entendo que Ricupero (2000) não cumpre bem essa a tarefa saudável de distanciamento, até pelo grau de encantamento pelo indivíduo que estuda, acaba mais por fortalecer certo heroísmo de um Barão, ao invés de compreender as tecituras que constrói, está imerso e, o autor acaba participando da condução de uma teleologia para tal personagem. Em certa altura afirmou (destaques meus): "Desde então [do resultado da Questão de Palmas] e até a

\footnotetext{
${ }^{103}$ Os três tipos ideais de liderança(s) cunhados por Max Weber (2003; 2004), me parecem apropriados ao (Juca) Paranhos Júnior, até em esferas e situações diferentes. Líder tradicional quando da ocupação de cargos via ação direta de seu pai, seja como professor substituto no colégio Pedro II, como Promotor de Justiça em Petrópolis (RJ) ou a indicação ao mais rendoso Consulado. Eleito duas vezes Deputado pelo Mato Grosso, tendo apenas na última, das duas eleições feito campanha pessoalmente. Líder burocrático quando assume a defesa do Brasil na Questão de Palmas, assim como anteriormente o cargo em Liverpool e no ministério das Relações Exteriores a partir de 1902. Barão falece sendo extremamente popular, líder pelo carisma com hábitos nos costumes de desfilar em carro aberto por uma Avenida no Rio de Janeiro que passou a levar seu nome e, era figura constante presente na imprensa. No livro $O$ dia em que adiaram o carnaval, Luís C. Villafañe G. Santos (2010) bem destaque a construção desse mito chamado, Barão.
} 
morte, dezessete anos mais tarde, [o Barão] não falhou em nada que empreendeu [...]." (RICUPERO, 2000, p.07).

Minha crítica não é no sentido de inviabilizar todo o livro de Ricupero (2000) Rio Branco, o Brasil no mundo, pois, pode haver trechos pertinentes e menos apaixonados, mesmo o autor vendo o Barão infalível. Quero aqui não esquecer àqueles mecanismos, pessoalmente de ordem pessoais, impulsionadores dos sucessos de Rio Branco. Se também utilizo o texto de Ricupero (2000) é com intenção de apontar quando segue por uma interpretação de encantamento com seu sujeito, quando, por exemplo, chega a aplicar à ascensão do pai do Barão também uma narrativa liberal: “Órfão sem riqueza, Paranhos pai subiu na vida por esforço próprio.” (RICUPERO, 2000, p.12). Discordo dessa interpretação que vê o individuo sem contextualizá-lo em um conjunto social ao qual participa, adere e ajuda a criar. Numa sociedade escravista, com forte marcador social da diferença na cor da pele, o pai de Juca, um branco, filho de português, mesmo não tendo origem nobre, também acessou possibilidades que não eram dadas a todos de maneira igual, equilibrada ou isonômica. Mesmo não sendo rico de berço, teve acessos.

Desde a infância, "Juca Paranhos acompanhou o pai em algumas de suas tarefas diplomáticas.” (SANTOS, 2012, p.64). Quando criança, morou em Montevidéu entre 1852 e 1854; esteve junto com seu progenitor em missões ao exterior em 1869. Depois, entre 1870 e 1871, acompanha a viagem do Visconde nas missões do Rio da Prata nos momentos finais da Guerra do Paraguai, quando o então major do exército brasileiro, Floriano Peixoto conhece o jovem Rio Branco. Coincidência desse encontro valida a ideia de existência da rede social de contatos e poderes do Visconde, ao qual o Barão é inserido, ainda mesmo jovem Juca. Afinal, mais tarde, em 1893 será o ditador presidente Floriano Peixoto quem nomeará o Barão do Rio Branco para atuar como advogado brasileiro no litígio com a Argentina, por sinal, é preciso lembrar em destaque (feito por mim): "questão [da Palmas] que seu pai foi um dos primeiros a negociar." (SANTOS, 2012, p.82). Indicou-se o Barão para liderar a defesa do Brasil em um litígio que o Visconde havia sido o iniciador de negociações, antes do litígio ser criado. Além disso, o Senador Paranhos havia dirigido mais de uma vez o Ministério correspondente ao das Relações Exteriores, no Império chamado de Ministérios Negócios Estrangeiros.

Antes de ser convidado para assumir função de advogado na Questão de Palmas, não há como negar como o primeiro grande salto conseguido por Barão foi ter sido nomeado para consulado em Liverpool em um dos mais bem remunerados cargos do 
Império brasileiro. Essa indicação certamente ele não conquistou sozinho. Mais uma vez, ser filho de alguém lhe contou com uma sorte danada! Sendo dos maiores portos do ocidente a época; no cargo de cônsul em Liverpool, Rio Branco permanece por mais de vinte e cinco anos. Sua nomeação foi conturbada, demorou um ano para que conseguisse sair a indicação oficial ao cargo. Envolveu relativa batalha dos líderes políticos do Partido Conservador para efetivar sua indicação, junto da aprovação de quem permitiria assumir rendosa função, a família imperial. Sinal de que no Império as indicações para cargos também foram usadas em trocas e barganhas.

Seu pai já havia deixado o comando do Conselho Geral dos Ministros; Dom Pedro II encontrava-se em viagem, mas na chefia do gabinete como primeiro ministro era um amigo do Paranhos pai. Pressionaram de todos os lados para a regente nomear Paranhos Junior. O ministro chefe do gabinete geral Duque de Caxias - "que o tratava por "теи Jиса"' (SANTOS, 2012, p.68) - chegou a colocar a disposição seu cargo, caso a nomeação não saísse: vitória dos conservadores que conseguiram a indicação de Juca em 1876. "A nomeação só foi arrancada durante uma ausência de Pedro II, quando a regente, princesa Isabel, foi confrontada pela ameaça da Caxias de demitir-se da chefia do gabinete se não lhe fosse concedida a nomeação do filho do Visconde." (SANTOS, 2012, p.69).

Barão parte do Brasil e passa a percorrer Londres e Paris, escapando muitas vezes do seu posto em Liverpool sem formal autorização. Acobertado, protegido e mais uma vez apoiado nas boas relações e contatos chaves herdados da influência de seu pai, Rio Branco desempenhará uma fluidez e alta mobilidade também na Europa, pois " $\mathrm{O}$ barão de Penedo, ministro em Londres e seu chefe imediato, era um velho amigo de seu pai e lhe facilitava as saídas de seu posto.” (SANTOS, 2012, p.70).

Liverpool além de muito oferecer com alta renda para quem ali atuasse, favoreceria proximidade com a atriz, companheira de Rio Branco, mãe de seus filhos que morava em Paris, mesmo ainda não casados, união aliás, polêmica para a época, fato confirmado pela realização do matrimônio somente e após, Barão ter se tornado um Barão (título recebido em maio de 1888, casamento em setembro de 1889). Inclusive, ele vivia muito mais tempo e dias na França do que na Inglaterra. Quando na capital francesa há quem diga, utilizava-se de uma fórmula pronta para resposta caso encontrasse com algum brasileiro conhecido: cheguei ontem e volto amanhã. (RICUPERO, 2000, p.19; MOURA, 2003, p.46). A leitura que faço é então, "ter mais sorte do que os outros" no momento de ascensão social, de conquista de cargos ou de 
nomeação para postos é resultado da capacidade de alcançar os interesses mobilizados e o poder, nesse caso, favorável ao indivíduo Juca, em uma clara disputa concorrencial desigual. Mas Ricupero (2000) não vê as assimetrias, quando afirma, por exemplo (destaques meus): “Trabalhador obsessivo, Rio Branco esforçou-se em programar cuidadosamente a fortuna, pondo toda sua virtú a serviço da criação de condições que lhe possibilitaram ter mais sorte que outros." (RICUPERO, 2000, p.07).

Não se trata de ter mais sorte do que Outros, mas a sorte (da nascença) de ser filho de um político influente no Império. Ao menos, se entendermos por criação de condições para ter mais sorte como algo normal das disputas, se não, foram de vantagens de berço do filho do Visconde que possibilitam Barão chegar aonde chegou; circunstância confirmada pelo recebimento do título nobiliárquico.

Em maio de 1888 quando da assinatura da Lei Áurea, o presidente do Conselho de Ministros era um ex-auxiliar do Visconde de Rio Branco, Correa Oliveira. Em homenagem ao Paranhos pai, seu antigo chefe e articulador da Lei do Ventre Livre, Correa conseguiu de Isabel o titulo de Barão ao Paranhos Júnior. Visconde havia falecido há aproximadamente oito anos e na esteira do fim da escravidão, Juca, tornavase $o$ Barão do Rio Branco como menção homenagem ao primeiro ministro da década anterior. Visconde de Rio Branco, promulgara a lei permitindo descendentes de escravos nascerem livres. Dois momentos de ausências do imperador Pedro II foram muito favoráveis a Paranhos Junior, em uma delas o gabinete conservador do Duque de Caxias conseguira força de pressão para sua nomeação no consulado de Liverpool, que lhe permitia estar na Europa e, o gabinete de Correa Oliveira ajudava-o tornar em 1888, um Barão. Em uma sociedade escravista e depois, republicana, o filho do Visconde conseguiu abrir boas portas para si, tendo-o como eficiente chave, a figura de seu pai.

Em 30 de março de 1893, devido ao falecimento de Aguiar de Andrade titular a frente da elaboração do processo de defesa do Brasil na arbitragem, a legação de Londres enviou o convite vindo do presidente Floriano Peixoto destino a Rio Branco. Assunto: assumir o posto de defensor da área em litígio, o que faz de imediato.

Passou ele então a corresponder-se com o ministro em Buenos Aires, Assis Brasil, e fez procurar documentação para sustentar o pleito brasileiro em vários arquivos da Europa. Em Washington, recebeu o apoio de Salvador de Mendonça, ministro brasileiro junto ao governo estadunidense. Ainda durante o Império, o republicano Mendonça havia sido indicado cônsul em Baltimore em 1875, graças à "boa vontade" do visconde e, portanto, conhecia Rio Branco, a quem anos mais tarde acusou a desejar "guardar para si todos os louros da vitória" (Mendonça, 1904, p.252) que ele iria colher no arbitramento. Essa avaliação, aliás, verdadeira, foi também compartilhada pelo segundo 
plenipotenciário da missão, o general Dionísio Cerqueira, que, certamente já frustrado por não ter recebido a posição de advogado titular quando da morte de Aguiar de Andrade, não pôde conter sua fúria ao saber que não tivera seu nome incluído como coautor da exposição escrita Rio Branco e entregue ao árbitro. Nem Cerqueira, nem nenhum outro membro da missão. (SANTOS, 2012, p.82).

Após resultado favorável da arbitragem nos EUA, retorna para a Europa, mas sem ir pessoalmente ao Brasil, mesmo sendo informado da popularidade do seu nome devido ao ganho da Questão de Palmas e, todo uso que os republicanos fizeram do mesmo, como tratei no começo desse capítulo. Enquanto está em Paris acompanhando da saúde da esposa, aproveitando-se de credibilidade positiva com o resultado da arbitragem de Cleveland, consegue do governo brasileiro sua nomeação como o negociador do litígio agora na causa da fronteira da Guiana Francesa com Brasil “Assim, sua permanência na capital francesa estaria justificada e ele se dedicaria a estudar e colher documentos sobre a questão.” (SANTOS, 2012, p.84).

Mas, em setembro de 1896 o ministro das Relações Exteriores considerado desafeto do Barão desde a Questão de Palmas, transfere de Paris para o Rio de Janeiro as ações envolvidas à defesa brasileira da fronteira com a Guiana Francesa. Entretanto, no Governo de Campos Sales, o nome de Rio Branco volta a ser lembrado para atuar no processo, e ambos se encontram, quando da viagem do presidente eleito pela Europa.

Barão é designado ministro em Missão Especial na Suíça para tratar a respeito da fronteira com a Guiana Francesa. Sobre essa nomeação, assim concluiu Luís C. Villafañe G. Santos (2012, p.84): “A situação política de Paranhos era, outra vez, de intimidade com o poder." Não é da proposta ou recorte temático avançar muito mais para os anos após a delimitação da fronteira com a Argentina, nem tampouco chegar na década em que o Barão foi ministro no Brasil. Mas considero valer chamar atenção como parte dos resultados dos ganhos de causa das fronteiras, tornou Barão cada vez mais popular e inserido em grupos de poder e esferas de saber reconhecidos como legítimos, tais instituições como Academia Brasileira de Letras, vaga assumida por Barão em 1898. Assim como, a presidência de uma das mais reconhecidas instituições de prestigio desde o Império, o Instituto Histórico e Geográfico Brasileiro-IHGB. Mas, sendo, segundo registrou o primogênito do Barão, a Royal Geographical Society de Londres a que lhe causou maior $\operatorname{prazer}^{104}$ no convite de ingressá-la. A indicação do

\footnotetext{
${ }^{104}$ Provavelmente pela sensação de distinção e de tradição que assumiram empresas coloniais que foram as sociedades de geografia. Na descrição de Raul do Rio-Branco (1942, p.93): "Foi Reclus quem, em reconhecimento pelas informações preciosas que obtivera de meu Pai, a cujos conhecimentos geográficos rendia homenagem, sugeriu à Royal Geographical Society, de Londres, sua eleição como membro
} 
Barão como membro correspondente no Brasil para ingresso na Sociedade de Geografia inglesa, foi do renomado geógrafo francês, Elyséé Reclus.

Da mesma forma, ter sido convidado para liderar o ministério das Relações Exteriores no governo de Rodrigues Alves também é resultado pelo largo crédito atribuído aos saberes do Barão, principalmente após o resultado e resolução de fronteiras, pois "para a opinião pública, as vitórias nas questões de Palmas e do Amapá afiançavam um conhecimento 'técnico' insuperável das intrincadas questões da diplomacia e das relações internacionais.” (SANTOS, 2012, p.90). As vitórias nesses pleitos, tornaram o Barão com notoriedade de vulto, "desgrudando-se" da imagem, apenas, de filho do Visconde.

É preciso mencionar também a continuidade dos usos de discurso de legitimidades de posse, vindas do Império. Tanto a opção pelas formas de realização e formalização de outros limites baseados no principio de ter sido domínio português via o uti possidetis, assim como a recorrência a arbitragem internacional, "tinha precedente na diplomacia de Pedro II, que assinou com a Argentina o tratado que conduziu ao arbitramento da disputa de limites na região de Palmas pelo presidente dos Estados Unidos." (SANTOS, 2012, p.111). Como afirma esse mesmo autor, Luiz C. Villafañe G. Santos (2012), desde o fim da década de 1840, o principio do uti possidetis consagrado como uma doutrina, permaneceu como eixo das negociações do Brasil. O Barão, também nesse quesito, pode ser considerado uma dessas figuras responsáveis, em tempos republicanos, pela continuidade de uma política imperial, ele mesmo um monarquista que não negara o baronato. ${ }^{105}$

\title{
Convencer para manter território: Palmas pertence ao Brasil. Alguns argumentos
}

\author{
Após a leitura da sentença, Zeballos cumprimentou \\ Rio Branco, afirmando: "queira aceitar, senhor ministro, minhas felicitações \\ pelo brilhante êxito que acaba de obter." A resposta do Barão foi: \\ "A vitória não é minha, nem do Brasil: é dos mapas".
} (DORATIOTO, 2012, p.52)

\footnotetext{
correspondente no Brasil. De todos os títulos e distinções honoríficas recebidas por meu Pai, em sua vida, foi essa que lhe causou maior prazer e que mais o lisonjeou, porque foi concedida [...] sob iniciativa de um homem como Reclus."

105 Desconfiou-se que Barão atuaria trabalhando em favor da restauração da Monarquia, mesmo após indicado como advogado do Brasil no litígio, parece ter sido colocado um espião a observá-lo: “O próprio Rio Branco tinha sido alvo de acompanhamentos e espionagem em Washington, por parte do governo brasileiro, quando atuou como advogado brasileiro da questão de Palmas." (SANTOS, 2012, p.93).
} 
Quando do resultado do laudo arbitral em 05 de fevereiro de 1895, dessa forma parece ter Barão respondido ao advogado argentino: a vitória fora cartográfica. Como se assim tivesse sido mais verdadeira, legítima porque cristalizado no mapa e, claro, sacramentada vitória, porque "comprovada" não pela vontade, mas por alguma materialidade real. Com quais argumentos Rio Branco buscou convencer a posse, em favor do Brasil? Antes vale mencionar, sendo no mínimo curioso, tratar das indefinições fronteiriças não resolvidas pelas metrópoles Ibéricas, tampouco acordado, propriamente pelos dois Países diretamente envolvidos ao recorrerem ao árbitro.

Para Rio Branco (2012, p.154), talvez nem seja preciso dizer, nenhuma das informações dos tratados, das convenções e mapas por ele (selecionado e) citados na Exposição de defesa do Brasil, favorece a pretensão argentina. E seria diferente, o advogado apresentar provas contra a sua causa? Ele recorre ao período colonial e das disputas pelo domínio do espaço Iberoamericano, para buscar deslegitimar a proposta da Argentina e favorecer ao Brasil. Parte dos capítulos do texto da defesa é a associação entre os acordos feitos pelos Países da Península Ibérica e suas possíveis marcas (ou marcações) no território. "O Pepiri-Guaçu era, portanto, o rio demarcado em 1759, o mesmo que o Brasil defende hoje." (RIO BRANCO, 2012, p.195).

Genericamente, pode-se dizer em poucas palavras, Juca Paranhos na defesa brasileira argumentou, como a área em litígio pertencia a Portugal, e tudo que fosse Portugal na América, seria brasileiro. ${ }^{106}$ Barão dedica bastante discussão ao século XVIII, principalmente ao Tratado de Madri (1750) e Santo Ildefonso (1777). Sendo o Tratado Preliminar de Santo Ildefonso o "[...] último ajuste celebrado entre as duas coroas de Portugal e Espanha sobre os limites das duas possessões na América Meridional.” (RIO BRANCO, 2012, p.62).

Um segundo argumento bastante enfatizado e constantemente dito no texto do Barão, afirma como principalmente a partir do século XVII, a elevada presença de paulistas e suas livres circulações na área de Palmas, consolida e demarca com o domínio, de fato, português. Rio Branco (2012, p.73) vai se remeter ao período da União Ibérica (1580-1640) como ocupação mais ancestral de população não indígena

\footnotetext{
${ }^{106}$ Rio Branco propõe "abandonar" a discussão sobre Tratado de Tordesilhas, alegando o mesmo não ter sido cumprido por nenhuma das duas Metrópoles Ibéricas, assim como ambas terem assinado tratados seguintes (além da própria União Ibérica 1580-1640) ter função desvalidara de Tordesilhas. A tese geral defendida: o de Portugal era, Brasil é. "Ao Brasil pertence incontestavelmente o território que na América do Sul pertencia a Portugal, com as perdas e aquisições que ocorreram depois dos Tratados de $1750 \mathrm{e}$ 1777; e, reciprocamente, aos Estados confinantes que foram colônias da Espanha pertence o que era do domínio desta nação, salvas as alterações que assinala o seu uti possidetis.” (RIO BRANCO, 2012, p.64).
} 
(não autóctone), argumentando paulistas terem "reivindicado" a área do que veria ser futuramente - Palmas para si e de domínio português, mesmo quando ainda vigente a União Ibérica. Provavelmente, por associarem os missionários (Jesuítas) com a Espanha, os paulistas - à procura de escravos indígenas e contrários a tudo que os impedisse das suas incursões - convinham dizer estarem sob tutela portuguesa. Barão informa $\mathrm{o}$ primeiro ataque paulista aos indígenas, na área de abrangência $\mathrm{e}$ circunvizinhança de Palmas em 1630. Seguida de regulares tomadas de assaltos os assentos das missões jesuíticas e suas destruições entre 1630 e 1638, inclusive com uma frente liderada por Raposo Tavares (RIO BRANCO, 2012, p.213).

Do ponto de vista paulista, provavelmente, era visto como empecilhos à escravidão indígena algumas das instituições associadas à Espanha da época da América Iberoamericana (sob o cetro da coroa espanhola), de maneira aos paulistas combaterem frontalmente tudo que fosse associado à causa da não escravidão. A leitura que Barão (2012) faz na Exposição da Questão de Limites, não aponta a expansão paulista no principal interesse no domínio e controle da mão de obra indígena, mas faz "dos brasileiros de São Paulo" defensores da conquista de um espaço português na América. Embora Rio Branco mencione o fator indígena como impulsionador das andanças paulistanas, os interpreta quase como restauradores da coroa portuguesa (antes mesmo da independência de Portugal ser refeita em 1640) e um sobrepeso desses mesmos paulistas, como se figuras-chave e fiadores do domínio da América portuguesa.

Não teriam os paulistas se utilizado de tentativas de uma "não vinculação espanhola", para exercer com maior liberdade suas entradas na caça aos indígenas? Barão do Rio Branco aponta que o fizeram em favor de Portugal. Não seria o inverso, dizer-se de Portugal para promover a ideia do não poder das missões jesuíticas (espanholas)? Barão parece ter encontrado nos paulistas uma maneira convincente de apresentar "súditos", representando interesses de Portugal na América, pois, mais de uma vez, diz terem feito guerras em nome das terras portuguesas: "No mesmo período [da União Ibérica] os brasileiros de São Paulo, chamados paulistas prosseguindo em suas expedições pelo interior, expulsaram os espanhóis e seus missionários jesuítas das posições que ocupavam em territórios considerados dentro da demarcação portuguesa [...].” (RIO BRANCO, 2012, p.72). 
A área de Palmas estaria fortemente presente no roteiro paulista. 107 "Ibituruna era, com efeito, o nome dado no século XVII à região entre o Uruguai e o Iguaçu, e os montes Bituruna do roteiro paulista não podiam ser senão os da divisória das águas que correm para aqueles dois rios.” (RIO BRANCO, 2012, p.217). Seria Palmas própria do uso paulista e entendiam pertence-lhes; contudo deixado de lado por uma prioridade quando “[...] passaram os paulistas a empregar-se principalmente no descobrimento e exploração das minas de ouro no interior do Brasil (Minas Gerais e Goiás), e no extremo oeste (Mato Grosso).” (RIO BRANCO, 2012, p.218). Embora, não tivesse sido uma área tão fixamente consolidada e com tanta presença paulista, como nas regiões auríferas da América portuguesa, por exemplo, no roteiro paulista das caçadas indígenas, Palmas estava incluso. Barão dá entender uma fixação esporádica, errática ou provisória dos paulistas pela área, com a tendência de ocorrer menos "nomadismo" com estabelecimento de fazendas, já na circunscrição do Brasil independente.

Do século XVIII em diante, os paulistas não aparecem mais no texto do Barão, apenas menciona seus resquícios, segundo descrito por comissões que deixaram documentos. Barão passa a usar, apenas, o termo brasileiro: "Os habitantes era, e são, em sua quase totalidade, brasileiro. Desde 1836 e 1838 ocupavam permanentemente o Campo de Palmas.” (RIO BRANCO, 2012, p.239).

Em quase totalidade da defesa apresentada, Rio Branco tratou de documentar suas constatações; enfatizou, principalmente, não serem apenas suas opiniões, mas, diz, avaliações - quando da área ser portuguesa (brasileira) - aparecendo também na opinião de comissões e comissários espanhóis. Ou seja, conseguir no relato, no documento

\footnotetext{
${ }^{107}$ Esse herói territorial que Rio Branco passou a ter na identidade brasileira, parece ter como seus heróis da conquista ou constituição do Brasil, a bandeira paulista (defende apaixonadamente, por exemplo, a ideia polêmica de Cabeza de Vaca não ter sido o primeiro a chegar na área, mas paulistas). Menciona como missionários espanhóis chegaram a criar postos de observações da movimentação paulista, para manter-se distantes dos preadores de indígenas. É presente duas grandes ideias principais ao longo do processo assinado por Rio Branco, a sua concepção de mito fundador da Pátria e domínio de Palmas o papel central dos paulistas. Outra concepção fortemente presente no dossiê é a demora da Argentina passar a reivindicar a posse da área, criando o litígio apenas recente. Vejamos essas duas principais linhas de defesa na seguinte passagem: "O Brasil funda o seu direito no fato de que já no século XVII o território a leste do rio Pequiri ou Pepiri, depois Pepiri-Guaçu, - descoberto pelos brasileiros de São Paulo, chamados paulistas, e não por Cabeza de Vaca, como ultimamente se alegou, modificando o conhecido itinerário desse governador espanhol, - era dominado pelos mesmos paulistas e fazia parte integrante do Brasil. Funda o seu direito no uti possidetis da epoca da independência, que era o mesmo reconhecido pelos missionários espanhóis quando, desde o século XVII até meados do XVIII, mantinham a oeste do Pequiri brasileiro um posto de observação para dar notícia dos movimentos dos paulistas; posse igualmente reconhecida pela Espanha no Tratado de 1750 e admitida pelo próprio governo argentino, porquanto no largo período de 70 anos, decorridos desde 1810 até 1881 , não manifestou pretensão alguma a fronteira mais oriental do que essa, e no período de 40 anos, decorridos desde a ocupação efetiva e permanente desse território por cidadãos e autoridades do Brasil, em 1838 e 1840, até 1881, não reclamou ou protestou contra essa ocupação brasileira." (RIO BRANCO, 2012, p.67-68).
} 
escrito, no texto do Outro algo que legitime a "minha posição", parece ter sido uma das mais substanciosas tendências de buscar legitimidade, convencimento e credibilidade, na defesa assinada por Rio Branco entregue em Washington em fevereiro de 1894.

Sobre caracterizar a presença de movimentações paulistas tratada como regular e constante, Rio Branco vai dizer, por exemplo, como se chegou a ocorrer estratégias para evitar as correrias inesperadas que os paulistas provocavam. "Até meados do século XVIII os jesuítas de Misiones mantiveram no [Rio] Uruguai [...] um posto de observação para dar aviso dos movimentos dos brasileiros de São Paulo, os paulistas." (RIO BRANCO, 2012, p.219). A presença paulista em Palmas e entorno, fazendo "as correrias dos povos das Missões", deixaram marcas, registradas no século XVIII pelas comissões de reconhecimento e demarcações espanholas, segundo dizia o Barão. Já, os indígenas e missionários, além de criarem as Espias ${ }^{108}$ para observação quando da maior proximidade ou chegada de paulistas, passaram a se preparar de maneira a "fazerem contenções" em resposta ao "avanço" paulista. "Desde o século XVIII tinham os jesuítas armado e disciplinado militarmente os seus índios para resistir aos ataques dos paulistas." (RIO BRANCO, 2012, p.102).

Essa presença paulista reforça sobremaneira a existência da escravidão indígena, influenciadora, inclusive, do afastamento das reduções jesuítas dessa área de Palmas. Para o Barão, a presença paulista é presença portuguesa, por isso, o que havia de mais ancestral de domínio brasileiro da área.

Basta dizer neste lugar que já em 1636 era nos Campos de Ibituruna, ou Terra dos Biturunas, hoje Campos de Palmas, a leste do Pepiri, que os paulistas se concentravam quando iam ao ataque das missões do Uruguai; que ali junto ao Pepiri, tiveram um forte ou acampamento entrincheirado; que ainda em meados do século XVIII os jesuítas das missões mantinham ao ocidente do mesmo Pepiri, no Jaboti ou Pepirí-Miní, um posto de observação chamado Espia, para dar aviso dos movimentos dos paulistas; que de 1636 a 1638 estes brasileiros destruíram todos os estabelecimentos que os jesuítas do Paraguai acabam de criar ao sul e ao oriente do Uruguai, e que só em 1687 aqueles missionários, que haviam concentrado os seus índios guaranis na mesopotâmia formada pela aproximação do curso do Paraná e Uruguai, se animaram a voltar para a margem esquerda deste último rio, assentando os fundamentos de sete aldeias, todas muito distantes do Salto Grande do Uruguai e do Pepiri. (RIO BRANCO, 2012, p. 84-85).

${ }^{108}$ Exemplo nessa passagem: “[...] os índios de São Xavier fizeram ao lugar que chamam a Espia, porque nele os dessa povoação se preparavam para não serem surpreendidos nas incursões dos paulistas, a quem primeiro estava mais exposta." (RIO BRANCO, 2012, p.112) 
Rio Branco chegou a repetir ${ }^{109}$ duas vezes (em partes diferentes do dossiê) a mesma citação de um relatório de comissionados espanhóis, em que se credita, ao longo dos trabalhos em campo para reconhecimento do espaço e demarcação - em março de 1759 - sinais da presença paulista, aparentemente do século anterior: desde pilão, roçados, malocas, panelas de barro bem cozido e com ornamentos. O próprio Barão sugere, o que poderíamos nominar de rugosidades na paisagem, "denunciando" ter existido presença paulista, principalmente, muros e restos de fortificações de estilo paulista: "Perto das cabeceiras do rio Saudade, afluente ocidental do Chapecó, e na longitude da foz deste rio, encontram-se ainda hoje, no Campo Erê, os chamados muros, que evidentemente são restos de fortificações antigas.” (RIO BRANCO, 2012, p.221).

Tais elementos de uma cultura material ou dos usos do espaço, Rio Branco interpreta, pelos relatos das comissões demarcatórias de acordos dos Países Ibéricos, como Palmas sendo um território paulista. ${ }^{110}$ Com ironia, Barão afirma "Os espanhóis, porém, nunca pisaram o território hoje contestado e suas vizinhanças senão nas duas ocasiões em que foram com os portugueses fazer a demarcação determinada pelos tratados de 1750 e 1777." (RIO BRANCO, 2012, p. 221). E quando pisaram gente da Espanha ali, argumentou o Barão, registraram em seus diários, era os paulistas quem deixavam marcas por ali. Claro, Barão sobrevaloriza tais relatos espanhóis, descrevendo resquícios paulistas em Palmas. Barão cadencia discursos das disputas Iberoamericanas.

A luta de Rio Branco pelo convencimento, esteve em reconstituir a apropriação predominantemente portuguesa/brasileira (caracteriza como paulista, até o século XVII). Em seu dossiê pipocam, ou aparece saltando os olhos pela repetição das frases

\footnotetext{
${ }^{109} \mathrm{Na}$ edição publicada no ano de 2012, a repetição das citações (com pequenas variações de palavras) estão nas páginas 117 e 220 de Rio Branco (2012). Trata-se de uma passagem do Diário da primeira demarcação dos comissários espanhóis, cuja data, diz Barão, é 06 de março de 1759: "Não distante deste segundo recife se achou na margem um morteiro, isto é, pilão velho, que pelo seu feitio conheceram os paulistas ser dos seus compatriotas, que o deixaram em alguma das suas antigas malocas, isto é, das incursões que faziam contra os índios destes povoados e também se viu um pequeno roçado de muitos anos, que se atribuiu aos mesmos." (RIO BRANCO, 2012, p.220). O advogado do Brasil no litígio apontou constatação de vestígios paulistas pela área também no Diário espanhol da segunda demarcação, no dia 11 de dezembro de 1789 em que cita o Barão: "[...] em 11 de dezembro, encontramos vários cacos de panelas de barro bem cozido e com ornamentos que sem dúvida devem ser de paulistas quando frequentavam este rio, para fazer suas correrias aos povos das missões." (RIO BRANCO, 2012, p.220).

${ }^{110}$ Em muitas passagens do dossiê, Rio Branco naturaliza áreas como pertencendo ao Brasil, mesmo antes da Independência, em uma clara narrativa em que coloca a existência do País na natureza. Como tratou essa discussão Demétrio Magnoli (1996), no Corpo da Pátria. Vejamos nessa passagem: "Quando adiante se tratar do território hoje contestado, da sua história particular, das expedições dos paulistas, ou naturais de São Paulo no Brasil, ficará demonstrado que nunca houve a leste do Pepiri estabelecimento algum, nem mesmo passageiro, dos espanhóis e seus missionários jesuítas, e que por eles foi esse rio considerado sempre, desde o século XVII, como fronteira do Brasil.” (RIO BRANCO, 2012, p.84).
} 
de engajada defesa, em um claro tom de processo de julgamento. É assertivo e decidido nas suas afirmações, buscando inscrever o espaço em uma presença e pertença imemorial brasileira. "O território contestado foi certamente descoberto por brasileiros e fez sempre parte integrante do Brasil." (RIO BRANCO, 2012, p.224).

Do último capítulo da defesa, Rio Branco apontou como já haviam sentado em mesas de negociações a Argentina e o Brasil, desde 1857, inclusive com assinaturas de tratados prévios e promessas de agilidades nas negociações. Embora em 1858 a Câmara e o Senado argentino tenham aprovado um tratado com o Brasil, o governo argentino teria deixado vencer (expirado) o prazo do mesmo, também pelo contexto de guerra interna na Argentina. Mas Barão não se faz de rogado e cita documentos (dos anos cinquenta dos oitocentos) de autoridades e governantes argentinos, reconhecendo área como brasileira.

Se do período colonial buscou justificativas nos espanhóis, para dizer ser domínio português da área, com os Países independentes (adentra no século XIX), tentará em discursos argentinos fontes para sustentar defesa brasileira. Citou passagens de documentos, para defender como argentinos já haviam manifestado pensamento como sendo do Brasil, o que a Argentina reivindicava como sua. O Barão é contundente na pontual lembrança, como por quase cinco décadas não foi feita nenhuma reclamação ou reivindicação por parte da Argentina.

Não obstante ter o Tratado de 1857 ficado sem efeito por falta de formalidade complementar da troca das ratificações, todavia é documento histórico da maior importância no estudo desde pleito, porquanto prova que o governo argentino, concluindo esse ajuste, e o Congresso argentino, aprovando$\mathrm{o}$, reconheceram expressamente naquela data o direito do Brasil à fronteira do Santo Antônio, Pepiri-Guaçu e Uruguai, direito já reconhecido tacitamente, pois desde 1810 até 1858 - durante 48 anos, - o governo argentino nunca formulou reclamação ou protesto de espécie alguma que manifestasse pretender fronteiras mais orientais do que essas (RIO BRANCO, 2012, p.230).

Barão buscou descrever possíveis créditos do Brasil com a Argentina, por ter realizado um apoio frontal de guarnição de área (justamente Misiones) argentina na Guerra do Paraguai, sem ter se apresentado interesses de apropriação de qualquer terra. ${ }^{111}$ Apontou, por outro lado, como ao final da Guerra do Paraguai, a Argentina teve

\footnotetext{
${ }^{111}$ Certamente a passagem a seguir apresenta um forte tom nacionalista, ainda mais em se tratando de uma circunstância da Guerra do Paraguai, entretanto, vale chamar atenção pela tentativa de transmitir uma ideia colaborativa, cooperativa e mesmo de um Brasil parceiro na relação com Argentina, pois o Brasil teria defendido (do Paraguai) a (futura) província de Misiones, inclusive durante Guerra do Paraguai fora essa área do território argentino, guarnecida pelas forças brasileiras.: "O Brasil pode dizer que concorreu poderosamente para que o território de Misiones, entre o Paraná e o Uruguai, ficasse definitivamente pertencendo à República Argentina. Concorreu para isso ocupando e protegendo esse
} 
certa dificuldade em não "se acertar" com esse País, indo ambos ao árbitro - também sendo os EUA - e perdendo o mesmo: continuou parte do Chaco reivindicado, a ser área de quem era, o Paraguai.

Além de buscar fazer o que parece ter sido uma espécie de "reconstituição da ocupação" brasileira na área, Rio Branco encerra o texto da defesa brasileira, estranhando ou colocando em suspeita a demora da Argentina em reivindicar a posse da área; segundo ele, os brasileiros poderiam dizer, ter a República Argentina durante 70 anos reconhecido a fronteira pelos rios Pepiri-Guaçu e Santo Antonio. "A reclamação argentina sobre o território brasileiro a leste do Pepiri-Guaçu e do Santo Antônio é de data muito recente." (RIO BRANCO, 2012, p.225). Alguns argumentos aparentemente pensados como mais simplórios, como àquele questionador de estar sendo recente a reivindicação argentina, fora deixado mais ao final do dossiê. Mas não significou ter menos capacidade provocativa e de inferior validade de peso na argumentação.

Nem só com base histórica feita pelo Barão, a partir de Tratados entre Portugal e Espanha, dos relatos das Comissões Mistas, das correspondências e acordos entre chancelarias etc., mas também de exposição de análise discutindo as possíveis contrariedades das posições e dos discursos da Argentina. Na abertura do dossiê elaborado, o Barão inicia fazendo referência ao último recenseamento do Brasil, do ano de 1890. Segundo afirma, dos 9.601 habitantes da comarca da Palmas, 9.470 eram brasileiros e 131 estrangeiros. Mas, "Entre esses não havia um só cidadão argentino." (RIO BRANCO, 2012, p.59).

Em algumas passagens da arguição do Barão está presente não uma abordagem da história para legitimar a brasilidade da área, mas fragilizar tentativas de legitimação de posse pela argentina. Visando apostar na vulnerabilidade dos argumentos argentinos, Barão questiona interesses de ressuscitar a questão das fronteiras pela Argentina, posto que nunca havia feito qualquer reclamação com interesse pela área de Palmas, até 1881. O ápice da crítica é apontar mapas oficiais da própria argentina, que localizavam a abrangência de Palmas como parte do Brasil. Assim, Barão procurou estranhar o porquê de não ter havido contestações argentinas, como haviam feito com disputas de áreas em outras circunstâncias? "Se julgava ter direito ao território a leste do Pepiri-Guaçu e Santo Antônio, devia ter protestado contra a sua ocupação administrativa, como

território durante a guerra, tomando sobre si a maior parte dos sacrifícios de sangue e dinheiro que a Tríplice Aliança teve de fazer, e prestando ao seu aliado, depois da paz, [...] para que essa questão de limites tivesse solução amigável e satisfatória." (RIO BRANCO, 2012, p.234). 
protestou contra a das ilhas Malvinas ou Falkland pelos ingleses." (RIO BRANCO, 2012, p.239). Enfim, questionava o Barão, por que demorara fazendo apenas um pouco mais de uma década que o Estado argentino passara a dizer publicamente litigiosa a área?

O documento foi entregue em fevereiro de 1894 nos EUA. Rio Branco propôs ao advogado argentino na querela, Zeballos, que trocassem entre si cópias das respectivas defesas, como relatou o filho, Raul:

Foi o caso que, tendo sido entregues as memorias pelas partes, meu Pai, ansioso por conhecer os argumentos contrários, propôs a Zeballos a troca das mesmas memorias, que aliás já não podiam ser alteradas, fazendo-lhe ver a vantagem, para cada qual, de descobrir alguma coisa imprevista na argumentação do outro. Mas Zeballos declinou a proposição [...]. (RIOBRANCO, 1942, p. 126).

Proposta não aceita pelo argentino; à espera do tempo da decisão do árbitro era obrigatória. Barão, entretanto, segundo relato de seu primogênito, "tinha sabido captar a simpatia de uma jovem americana, noiva de um dos auxiliares diretos do Presidente." E, "Por ela", escreveu Raul do Rio-Branco (1942, p.127) que esteve presente acompanhando seu pai no dia da leitura do resultado na Casa Branca, "soube [o Barão] que podia esperar sem muitas apreensões.” (RIO-BRANCO, 1942, p.129).

Tendo a resposta no ano seguinte às defesas apresentadas, era manhã de 05 de fevereiro de 1895. As repercussões do voto do árbitro favorável ao Brasil foi o tema do início desse presente capítulo. A República deitou e rolou com a boa nova. O Brasil ganhava reconhecimento internacional de uma área, e junto, um novo herói; herói desse território, dando início a uma figura de herói territorial. ${ }^{112}$

O laudo posicionando a defesa do Brasil foi assinado ao final, sem o nome civil ou de batismo, e sem o claro e prévio título nobre de Barão, mas escrito, apenas, como o nome que agregou desde seu pai: Rio Branco. Desde o Visconde, Paranhos pai, passando pelo Barão, Paranhos Júnior, o simbólico da luta pelo resguardo e manutenção do espaço brasileira é grande. Não se transmite, apenas, o que é possível do capital político, mas também a luta pela manutenção brasileira, e do que lhe parecer ser visto como essência(l), seu território.

\footnotetext{
${ }^{112}[\ldots]$ sem que fizesse derramar uma gota de sangue nem uma lágrima de mãe, ele ampliou o território nacional, como nenhum conquistador militar pode fazer [...]. (RIO-BRANCO, 1942, p.205)
} 


\section{CAPITULO III}

\section{UM BANDEIRANTE NO ÚLTIMO ANO DA DÉCADA DE 20, DO SÉCULO XX:}

O caso do Oeste de Santa Catarina e a Viagem do Governador em 1929

\section{A constituição do Sertão: o Oeste de Santa Catarina}

Se hoje em democracia, interessa aos candidatos aos poderes eletivos percorrem em momentos de campanhas eleitorais, o máximo de espaços, deixando-se serem vistos por grande número de pessoas em um curto período tempo, buscando traduzir tal exposição em maior número possível de votos, ao que parece, no Brasil atual, quando eleito um governante as pessoas "já o conhecem", mesmo que por meio das redes sociais ou mídias/televisão. Talvez por isso, hoje, a visita de governantes à determinada região possa ser tratada como uma presença convencional. Até porque o próprio representante eleito pode ser "originário" da região, assim como há muitos discursos de políticos que a exaltam, afinal, dali pode estar à vitória em um pleito. ${ }^{113}$ Mas, haveria pretensões de regularmente insistir e reforçar lembranças de quando esteve em alguma região pela primeira vez, uma autoridade, tal qual um governador?

Na cultura política de Santa Catarina, há várias datas fundantes no século XX que os registros da história oficial costumam enfatizar. O ano de 1929 é uma delas. Muitas pessoas nunca haviam visto a face do que se denominava ${ }^{114}$ na época, Presidente, em referência ao que hoje chamamos Governador de Estado. E junto do tempo, há um espaço: o Oeste catarinense. ${ }^{115}$ Para exemplificar a perpetuação dessa referência, basta lembrar que ainda hoje se costuma cobrar, por exemplo, de vestibulandos para que atentem a esse fato ou ainda, é um relato bastante presente em

\footnotetext{
${ }^{113}$ Como lembra Sandra Lencione (1999, p.20): "Quem não conhece um político que busca sensibilizar eleitores por meio de apelos ao regionalismo? Um político que disputa recursos orçamentários em nome da defesa de interesses regionais?".

${ }^{114}$ Não fora sempre assim, pois segundo Jali Meirinho (1997, p.197) a Constituição estadual de 1928 mudou o nome do chefe do executivo de governador para presidente.

${ }^{115}$ Renk (2006, p.09) denomina de Oeste catarinense às regiões coloniais do extremo Oeste como o Rio do Peixe. Para autores de epoca aqui tratados, geralmente - na direção leste ao oeste - é após o Rio do Peixe que se localiza o Extremo Oeste.
} 
publicações de livros paradidáticos de historia catarinense, ao qual o nome do governante é marcado como o primeiro a ter ido até os limites finais das "nossas terras", quando se começa após o rio Peperi-Guaçu, a Argentina.

Entretanto, em uma abordagem da alteridade, o Outro não é apenas aquele que está fora do território a qual pertencemos, nesse caso, o argentino, mas os próprios habitantes desse Oeste, que o governador Adolpho Konder (1884-1956) é considerado o primeiro a oficialmente ter estado presente. A maneira como nos documentos de época referem-se à presença do governante, permitem interpretar como um espaço Outro do litoral, dos vales e da serra catarinense, eram os: "não-integrados", isolados e desprovidos de contato que passavam a receber a sorte de poderem contar com visita de uma ilustre autoridade. E, como foi apontado entre discursos oficias, os demais motivos do governador se deslocar ao Oeste, estava na sua consciência da obrigação em "abrasileirar" tal região, como relataram alguns dos secretários de governo, burocratas e homens das letras que fizeram parte da comitiva (BOITEUX, 1931; COSTA, 1929, D’EÇA, 1992). ${ }^{116}$

Colocar em prática o destino daquela região, fazendo-a brasileira. Duas as principais características da Viagem do governador, na avaliação de um dos participantes: o caráter de bandeirismo e de missão. Os três autores das descrições da Viagem acreditavam na necessidade de conhecer os ainda não abrasileirados e consideravam suas observações e presença relevante, pois realizadas em nome da nação, como, a de garantir a apropriação das terras por brasileiros. Percebe-se a tendência de uma narrativa, como se fosse a implementação mais do que um compromisso de governo, uma aventura em que a própria equipe acompanhante do governador faz uma descrição importante de si mesma e seus atos, buscando legitimar seu discurso e ação.

Cruzada pela fé profunda, pelo religioso civismo que nos aquece e anima; Bandeira, pelo espírito de aventura, pela esplêndida brasilidade [...] a tomar posse definitivamente e absolutamente de uma grande porção de Santa Catarina, em nome da Pátria. (D’EÇA 1992, p.79). [negritos feitos por mim]

O Oeste era o Outro em relação ao restante de Santa Catarina, em um claro exemplo de tratamento de uma noção de Sertão: espaço distante a ser conquistado em favor de um conjunto maior, ao qual, não necessariamente parece fazer parte os habitantes desses Sertões, que embora apareçam nas descrições como sertanejos, são considerados como população a ser diluída nos projetos colonizadores para tal espaço.

\footnotetext{
${ }^{116}$ Aqui utilizo a segunda edição do “Aos espanhóis confinantes” (D’EÇA, 1992), a primeira data de 1929.
} 
Trata-se do imaginário presente da cultura brasileira, do Sertão como desprovido de qualidades e de "valores" a ainda serem descobertos, cadastrados e mesmo reelaborados. A busca por entender a profundidade ${ }^{117}$ desses espaços, inventariando e descrevendo o Sertão, fora inclusive, segundo Antonio Carlos Robert Moraes (2009), um dos motivadores e legitimadores, em determinadas epocas, para existência e justificativa dos estudos ${ }^{118}$ de geografia brasileira: "Descrever os sertões tem sido uma das metas praticadas pelo labor geográfico no Brasil, aparecendo mesmo como um elemento forte de legitimação desse campo disciplinar em diferentes conjunturas históricas do país." (MORAES, 2009, p.88).

Segundo esse mesmo autor, no curioso texto: "O sertão: um outro geográfico", embora seja difícil encontrar uma característica que o unifique ou qualifique enquanto uma unidade conceitual, devido aos diversos elementos genéricos apontados, no Brasil, o Sertão é uma entidade recorrente na história territorial. Em Santa Catarina dos anos 1920, nos relatos aqui analisados, percebe-se como a ideia que se tem do Oeste é de sinônimo de Sertão, como uma busca do espaço estranho a ser conhecido, incorporado e acima de tudo, passar a fazer parte de domínios territoriais a serem definitivamente estabelecidos. É importante buscar compreender o destaque da noção de Sertão, pois dependendo da forma como é interpretada, pode auxiliar nas interrogações a respeito da presença do governador naquela ocasião, como segue o trecho que considerei extremamente pertinente para o contexto catarinense aqui discutido:

O sertão é comumente concebido como um espaço para a expansão, como o objeto de um movimento expansionista que busca incorporar aquele novo espaço, assim denominado, a fluxos econômicos ou a uma órbita de poder que lhe escapa naquele momento. Por isso, tal denominação geralmente é utilizada na caracterização de áreas de soberania incerta, imprecisa ou meramente formal. No geral, utiliza-se o termo sertão para qualificar porções que se quer apropriar dos fundos ainda existentes no território nacional em cada epoca considerada.

\footnotetext{
${ }^{117}$ No final dos anos 1920 em Santa Catarina, a ideia do Oeste como o Sertão, nos dá pistas de que havia fatores motivacionais para classificá-lo como uma oposição à civilização. Um dos principais interesses é incorporá-lo plenamente, mais do que apenas por via de invenção de rituais de fortalecimento de consciência e identidades de pertencimento. Como bem abordou Antonio Carlos Robert Moraes (2009, p.96): “[...] a mera qualificação de uma localidade como sertão já revela a existência de olhares externos que lhe ambicionam, que ali identificam espaços a serem conquistados, lugares para a expansão futura da economia e/ou do domínio político. Transformar estes fundos territoriais em território usado é uma diretriz que atravessa a formação histórica do Brasil, alçando-se mesmo à condição de um projeto estatalnacional básico do país." Sobre a centralidade da noção de Sertão e sua relação territorial brasileira ver também: Gilmar Arruda (2000): "Cidades e Sertões: entre história e memória" e Ricardo de Oliveira (2002) "Euclides da Cunha, Os Sertões e a invenção do Brasil profundo."

${ }^{118}$ Não seria a obra de Orlando Valverde (1957, p.16) um exemplo? Quando nessa passagem menciona: "Nem mesmo o homem, que atravessa a serra há quase 300 anos, conseguiu fixar-se nesta sertão hostil. Ela é, até hoje um deserto demográfico."
} 
Nesse sentido, trata-se de um qualificativo que induz um novo processo de domínio territorial sobre os espaços enfocados, isto é, que introduz um novo surto de dominação política no âmbito espacial delimitado pela qualificação proposta. (MORAES, 2009, p.90-91).

Para além de despertar curiosidades, naquela Viagem de 1929, muitas fotografias $^{119}$ e imagens da epoca foram colididas em um álbum, o que também configura um processo de ritualização, catalogação, levantamento de material e documentação a respeito do processo de reconhecimento de uma "nova" área. Alguns desses álbuns fotográficos distribuídos entre comunidades e em contato com as populações que o governador percorreu, como um mecanismo para as pessoas o reconhecerem como agente de poder. É pertinente apontar a descrição que aparece abaixo de uma imagem de floresta e serras ao fundo reforçando mais uma vez a classificação a que foi atribuída ao Oeste catarinense. Entre o firmamento e a terra: as imensidões do Sertão a serem acoplados ao território usado.

O presente capítulo "manuseia" uma massa documental para, a partir dos textos e algumas imagens (como fotografias, por exemplo) a respeito da Viagem de 1929, entender tanto a representação de um território que foi percorrido, assim como a construção material desse território que é edificado em movimento: no próprio processo de renomear, "batizar", "cartografar", descrever nomenclaturas locais, referenciar, comparar, valorar e medir determinada área terrestre, afinal “[...] é a própria apropriação que qualifica uma porção da Terra como um território.” (MORAES, 2005, p.45).

\footnotetext{
${ }^{119} \mathrm{O}$ álbum de fotografias, intitulado "Roteiro da excursão do Presidente Adolpho Konder ao Extremo Oeste Catarinense" foi republicado em edição fac-simimilar pelo: CEOM/Centro de Memória do Oeste (Org). "A Viagem 1929: Oeste de Santa Catarina, documentos e leituras." Chapecó: Editora Argos, 2005. Nesse livro organizado pelo CEOM, também foram republicadas as obras de Costa (1929) e de Boiteux (1931). Sobre o tema, ver mais em Arlene Renk (2005; 2006).
} 
Imagem 10: A legenda no rodapé da foto, "regionaliza" parte de Santa Catarina como sertão

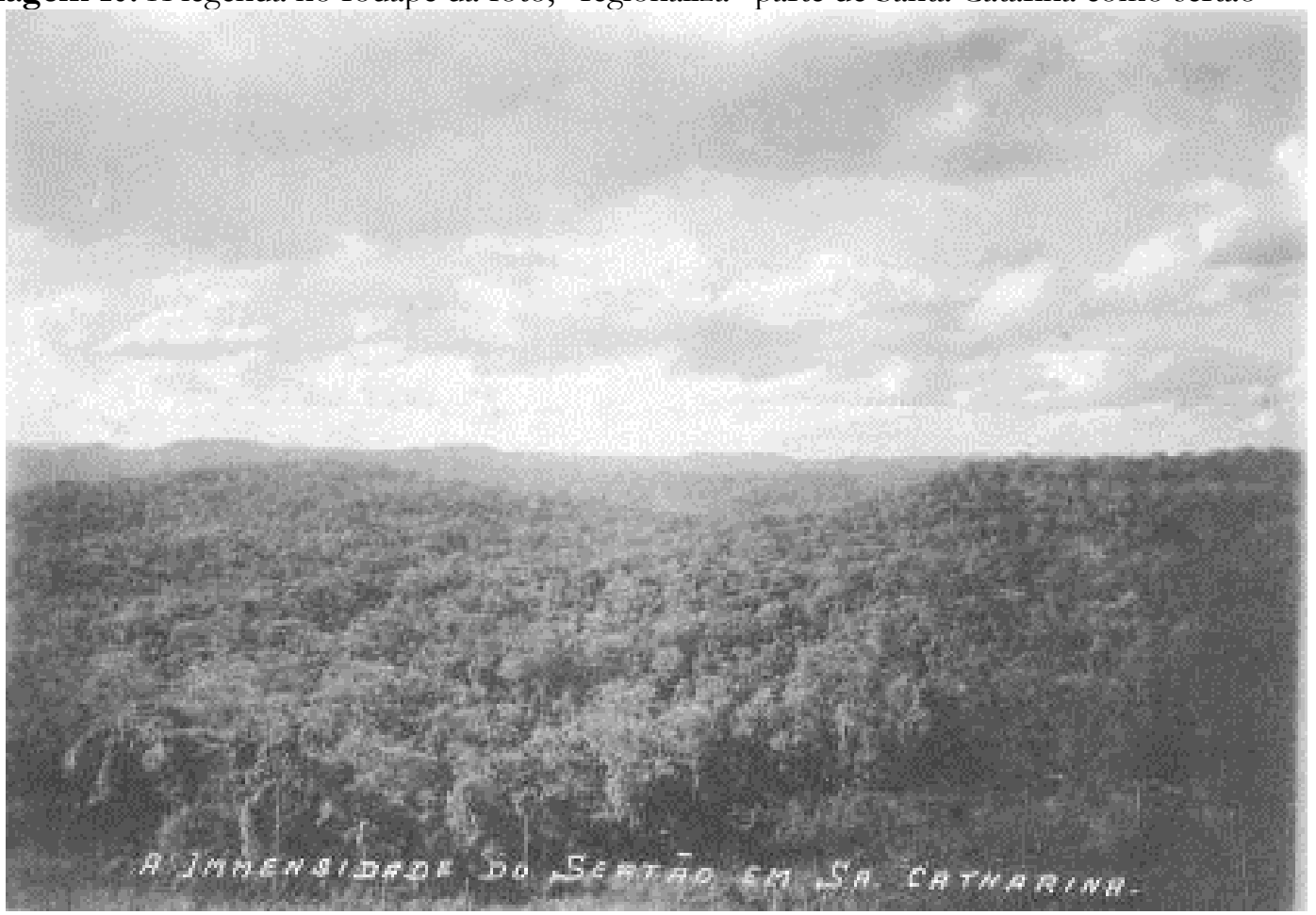

Fotografia sem autoria (disponível em: CEOM, 2005), caracteriza aos que não fizeram parte da Viagem de qual palco se tratava a "expedição" e para aqueles que habitavam nessas paisagens que se reconhecessem como habitantes dele. A Viagem de 1929 utilizou de fotografias como mecanismo de representação de poderes sobre os espaços. Regularmente aparecem imagens do governador, em situações ou atos "inaugurais" de desbravamento de área, realizando discursos entre pessoas e de encontro entre diferentes.

Os documentos analisados na primeira parte desse capítulo são além de esporadicamente os relatórios anuais do governo de Adolpho Konder (1926-30), três obras principais, duas delas publicadas no mesmo ano da Viagem e uma publicada em 1931. Trata-se dos diários e textos de três observadores (BOITEUX, 1931; COSTA, 1929; d'EÇA, 1929/2ed: 1992), todos funcionários de governo que após acompanharem a viagem e no percurso da mesma, fizeram mais do que anotações ou relatos sequienciais por onde passaram. Elaboraram discursos interpretativos e constitutivos de análises das pessoas, dos lugares e interpretando a região que desejavam incorporada. São enunciados que buscaram descrever para demais partes do país (particularmente para os catarinenses) de outras regiões, aquela parte do estado a ser integrada. Escritos no "calor da hora" tais documentos recebem no presente estudo um tratamento metodológico - são fontes primárias - articulando com bibliografia pertinente às análises de cunho territorial, pois no olhar dos participantes “daquela missão" em 1929, ao território catarinense que se quer ver incorporada a região Oeste e fazer uso dela. 
A interpretação aqui seguida é aquela que entende que ao representar um espaço, apropriá-lo e, portanto, territorializá-lo, está articulado o processo de reconhecimento: a descrição das "qualidades" de uma determina porção do planeta (e suas variáveis representações) e de empoderamento do mesmo: seus limites, nomes reconhecidos como oficiais e área de abrangência de uma jurisdição. $O$ caso da presença oficial de um governador, pode bem ilustrar essa articulação entre o simbólico e o material, que poderia ter na elaboração de um mapa ou na mudança do nome de algum lugar, por exemplo, seu ápice. Estou completamente de acordo com a conclusão de Fernando Vojniak (2005) quando ele observou alguns desses mesmos documentos que seguirei analisando, uma sutil mescla: "A Bandeira Konder e seus atos e registros tornam-se fundamentais para análises da produção do Oeste catarinense, pois o rito de passagem, de conhecimento e reconhecimento do território produz, também, o território." (VOJNIAK, 2005, p.14). Afinal, é importante não esquecer, como disse Claude Raffestin (2009, p.35): “A imaginação é um elemento constituinte da territorialidade, porém, raramente é explícita."

A primeira de algumas das imagens da obra "O Oeste Catharinense" - o autor dedicou $^{120}$ o livro a Adolpho Konder - Arthur Costa (1929, p.06) apresenta em seguida ao sumário e antes de começar qualquer texto, uma "representação cartográfica" ao qual mostra o trajeto de todo o percurso realizado entre 17 de abril e 18 de maio de 1929. Em negrito está à saída de Florianópolis, os pontos de parada e o retorno, em um percurso total de quase $3.000 \mathrm{~km}$. Nota-se nesse desenho (a seguir, Imagem 3) como há uma legenda explicativa no canto esquerdo inferior, detalhando os meios de deslocamentos utilizados no percurso; mas também chama atenção a opção de onde foi localizada a expressão, conforme a escrita da epoca, em maiúsculas: "EST. DE S. CATHARINA". O nome do Estado na mais extrema parte Oeste desse "mapa" ou melhor, a referencia de um espaço cartografado, configura um interessante exemplo de representação do poder que se torna visual a partir de uma carta representativa dá área total catarinense e da região em particular. Pode-se bem problematizar tal desenho, ao se associar com a afirmativa realizada por outro observador que também escreveu a experiência e assim considerou ao percorrer a região: "Está pois integrada a Santa Cathatina, direi melhor,

\footnotetext{
${ }^{120} \mathrm{Na}$ dedicatória, expressa a Viagem como um exílio: "Ao Presidente Adolpho Konder. Lidimo e intrépido 'bandeirante' aquém se devem a ideia e o exílio da jornada ao Papery-Guassú'." (COSTA, 1929).
} 
ao Brasil, extensa faixa de terra, cujo abandono - triste é dize-lo - era manifesto." (BOITEUX, 1931, p.25).

Imagem 11: Trajetória da Excursão do Governador Adolpho Konder em 1929

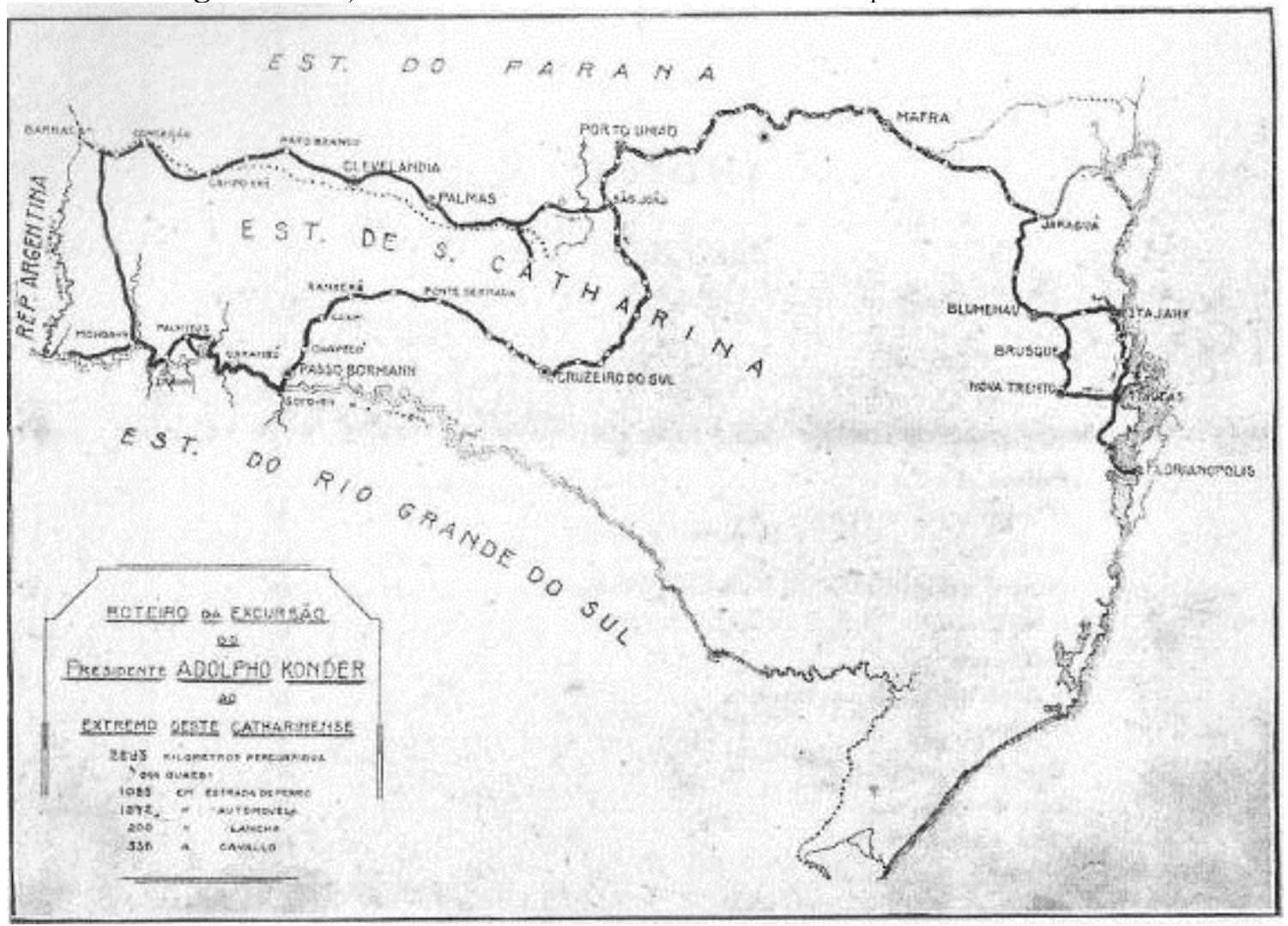

Imagem sem autoria (ref, COSTA, 1929, p.06) publicada no livro "O Oeste Catharinense", destaques para: a) Localização da nomenclatura do Estado de Santa Catarina justamente no extremo-Oeste. b) Detalhamento no canto esquerdo inferior do total da distância realizada por diferentes meios: "2893 quilômetros percorridos. [Destes:] 1085 em Estradas de Ferro, 1272 em Automóvel, 200 quilômetros em lancha e 336 quilômetros a cavalo." (COSTA, 1929, p.06).

O livro de D’Eça (1992) e Boiteux (1931) não utilizam nenhuma imagem. Mas José Boiteux (1931, p.26), utiliza-se de uma metáfora da corporeidade humana para se referir ao trajeto percorrido. Como se costuma fazer nessas comparações, elege-se um membro primordial humano, tornado paralelo da "corporeidade" do espaço. A trajetória percorrida pela expedição é comparada ao coração ${ }^{121}$ tanto pela importância da localização, a partir do centro para o Oeste do território catarinense, como pela amabilidade e afinidade com que as pessoas receberam os forasteiros vindos da capital.

121 “'...] dupla excursão pelo coração catharinense. Pelo coração, centro do território do Estado, e pelo coração, pois que tão repetidas e tão justamente prestadas foram as homenagens, carinhosas em extremo, por elle recebidas da população rural barriga-verde [...] até o ancião que, nunca tendo conhecido um governante, desde que Santa Catharina se abriu para a administração pública olhava nosso presidente entre agradecido e admirado." (BOITEUX, 1931, p.26). 
Alguns dos municípios e localidades classificados nessa imagem anterior possuem até hoje, os mesmos nomes, conforme se pode notar ao fazer comparações com mapas atuais de Santa Catarina. Entretanto, no seu relato, Arthur Costa (1929) parece tentar deslegitimar muitas das nomenclaturas e toponímias que acabara de conhecer e promove uma tentativa de ridicularização dos nomes de lugares aos quais não parecia concordar, não entendia o significado ou, considerava de pouca representatividade simbólica. Começa dizendo em certa altura de seu relato: “[...] os nomes dos lugares são de curiosa escolha." (COSTA, 1929, p.58). Para em seguida, criticar as nomeações de lugarejos: "Não têm conexão de sentido com o que deveriam exprimir. É assim que em [na comunidade de] Flores não se encontra inflorecencia alguma. Nenhuma corolla.” E arremata: “O mesmo em [na localidade de] Fartura, onde passamos fome." (COSTA, Ibidem). Essa disposição de inferiorizar as denominações já existentes é acompanhada de outras descrições com desejos de subalternização e em verdade, de uma sobreposição cartográfica, portanto, de um reordenamento do poder.

Como Milton Santos (1997) afirmou, o não conhecimento das histórias da constituição de determinado espaço é uma relevante alienação das pessoas com sua base territorial. Disso é possível encontrar exemplo do Oeste aqui discutido, como um projeto de "resgate" de fundos territoriais em favor de membros externos a esse espaço, fabricando em consequiência um tipo de alienação das pessoas vivendo na região antes da chegada das autoridades. Embora não seja necessariamente a retirada de posse (desapropriação de terras), as tentativas bem-sucedidas de alteração dos nomes, mudanças de toponímias e os discursos visando subalternizar/inferiorizar os nomes até então utilizados, podem ser vistos como um primeiro momento de desapossamento (HARVEY, 2013, p.330), mesmo que aparentemente não seja uma mudança material ou tangível. Na lógica da expropriação, talvez a mudança do nome seja o primeiro passo para efetivar uma nova captura desse espaço para uma nova lógica, como o da afirmação da propriedade privada.

Ao adotar o posicionamento de tornar institucional novas nomenclaturas do território, rebatiza-se lugares e os insere em mapas, buscando exercer melhor controle sob os mesmos e em conseqüência, perda de algumas de suas referências até então vividas. Ou, como refletiu Quaini (2009, p.130), o mapa pode ser considerado um dos mecanismos mais potentes de transformação ou negação dos lugares. Percebe-se um desprezo pelos nomes existentes e muito das toponímias passam a ser substituídas. A forma de tratar as nomenclaturas dos lugares como desimportantes é perceptível no 
relato dos membros da comitiva. Ao passear por uma corredeira, percebe-se a existência de guias e auxiliares não-brancos vivendo pela região, como nota-se nesse relato, em que autor recusa saber algumas toponímias: "O timoneiro - um caboclo destorcido que se chama Areias - avisou-nos de que dentro de alguns instantes vamos passar a primeira corredeira. E disse um nome. Mas a mim não me importa o nome.” (D’EÇA, 1992, p.24).

No mesmo relato, mais em frente, o observador vai descrever como havia rituais de batizados de locais, assim como comemorações de datas simbólicas da nacionalidade. Outras características e práticas acompanhavam as mudanças de nomenclaturas: “Amanhã, data de comemoração do descobrimento do Brasil, haverá uma comemoração cívica: alvorada com salvas de revólver e, às nove horas, hasteamento da bandeira nacional pelo presidente; depois: batismo do ribeirão que banha o acampamento e que passará a se chamar ribeirão 3 de Maio." (D’Eça, 1992, p.75).

Um dos mecanismos de projeção de poder está na recomposição de nomes, símbolos e valores. Esses avaliadores "externos" em típico movimento de expansão de fronteira, elegem os nomes a serem mantidos, as vozes que vão considerar autorizadas a auxiliarem nas (re)nomeações e as toponímias que passam a considerar válidas e pertinentes na elaboração dos novos planos, desenhos, traçados e nomenclaturas. Seja em cartas de localização ou nos documentos oficiais elaborados, houve uma busca por invisibilizar muitas das toponímias existentes:

Durante a travessia, auxiliado por sertanistas e pelas informações do Dr. Werner, um inteligente alemão ligado à Empresa Chapecó-Pepery Limitada, foi o presidente Konder, juntamente com o engenheiro Breves, corrigindo os enganos e preenchendo as omissões do mapa atual [...] e dando nomes aos [locais] que os não têm, reunindo, assim, elementos para a melhoria de confecção do novo mapa do Estado, em preparação. (COSTA, 1929, p.30). [destaques em negrito feito por mim]

A nomeação dos lugares é uma clara invenção social ou em uma linguagem geográfica: um importante atributo das construções territoriais. Por isso, observa-se de alguns agentes participantes da Viagem, uma super atenção para as possibilidades de descrição, referencial e reconhecimento dos lugares; as práticas de inventário e renomeação dos lugares é uma rotina realizada com atenciosa dedicação: "O Arthur Costa examina pela centésima vez, a carta do Estado e assinala acidentes mínimos de viagem". (D’EÇA, 1992, p.30). 
Às vezes trava-se uma batalha para fazer com que determinada nomenclatura passe a valer e fazer sentido como denominação, se não reconhecido por todos, ao menos seguida pela maioria e resguardada a continuidade desse nome pelas instituições oficias. Afinal, como já se percebeu do próprio desenvolvimento da elaboração de roteiros, portulanos, cartas e signos de localização, quando naqueles contextos de incorporação, posse e conquistas de espaciais “[...] as necessidades de conhecer a extensão real das colônias, assim como de lhe demarcar os limites, incidem sobre o desenvolvimento da cartografia." (MORAES, 1989, p.19). E desenvolvimento de uma cartografia não apenas de relevos, bens naturais ou das particularidades de biomas, mas também de nomenclaturas de tudo que seja denominável nos mapas. E, em se tratando de influencia externa e região fronteiriça, o nacionalismo ali mais candente, sugere os nomes refletindo e promovendo o espírito nacional. Remete-se também a ideia de uma língua nativa, como se a caminho entre a língua portuguesa e as expressões indígenas:

Aproveitando a oportunidade e no afã de identificar verdadeiramente a região percorrida, o presidente, o Breves, e o dr. Werner fizeram retificações topográficas e hidrográficas, dando nomes a lajeados, a ribeirões, a acidentes naturais, que ainda nem se achavam assinalados nos mapas!

Como é vasto e desconhecido este nosso querido Brasil!

Mas, ao batizar essas águas novas, o presidente tem tido uma nobre preocupação nacionalista: dá-lhe sempre nomes brasileiros: - Lajeado do Saci, Ribeirão da Bracatinga.

Nada de designação arrevesadas, que o caboclo não pode pronunciar e nada significam.

Estamos no Brasil e o vocabulário brasileiro é farto e expressivo.

E o manancial luso-guarani inesgotável e belo, como nenhum outro. (D’EÇA, 1992, p.84). [destaques em negritos feitos por mim].

Entre aqueles burocratas que acompanham políticos, há alguns preocupados em fazer menções ressaltando a distinção dos nomes, seja na importancia da pessoa em vida e com a morte passando a ser alguma toponímia, ou também referindo-se a importância da língua usada, sonoridade e o regular uso do que nomina. Oficiais de gabinete se atribuem o dever de lembrar os nomes dos lugares, o por quê das autoridades homenageadas e "pedagojizar" o texto mencionando regularmente as pessoas poderosas, quem elas foram e o que fizeram. Algumas dessas narrativas evitam com que se caia no esquecimento, tentando sempre fazer lembrar da "importância" do nome ao qual foi atribuído a um dado lugar. Embora se falasse em toponímias favoráveis à pronuncia e ao entendimento pelos caboclos, simultaneamente buscava-se uma substituição desse grupo étnico por imigrantes brancos de origem europeia. Eram esses imigrantes, a população preferencialmente aceita à colonizar o Oeste. 
É possível observar alguns dos documentos formulados pela Viagem, como naquele Álbum Fotográfico criado pela própria expedição, nele também se nota no "mapa" (Imagem 3) antes aqui referido (COSTA, 1929) como no caso da localidade Dionísio Cerqueira $^{122}$ (atualmente município com o mesmo nome) é regularmente nomeada de Barracão. Os próprios narradores tem dificuldades de chamá-la de Dionísio Cerqueira devido às recorrências de referencia ao nome Barracão: "Meia-légua antes de Barracão - Dionísio Cerqueira é um nome oficial [...].” (D’EÇA, 1992, p.105). O silencio dos autores sobre quem a nomeou é questionador: fora o Estado do Paraná, considerando sua área de abrangência, quando em 1903 eleva a povoação à vila e nomeia de Dionísio Cerqueira, segundo informa a "Enciclopédia dos Municípios Brasileiros" (IBGE,1959, p.93). Quando práticas - como a nomeação - realizadas por paranaenses, os autores catarinenses aqui tratados, não fizeram qualquer menção do crédito ou lembrança de quem assim havia nomeado de Dionísio Cerqueira.

Não apenas o nome, mas as diversas instituições formais ou informais dali refletem naquele momento, segundo a descrição dos "viajantes", uma polarização seja da Argentina ou do Paraná e um profundo distanciamento das "coisas catarinense". Um dos autores relata que do consumo de necessidades ali não produzidas, eram adquiridas, tais bens, procedentes de Buenos Aires e arredores da capital Argentina. É tratado como inspiração, a maneira da República argentina fazer gestão e administrar sua fronteira; com serviços do Estado muito mais presentes e constante em relação à fronteira brasileira, os autores relatam admirados tanto a presença de autoridades argentinas como uma maior influencia direta vinda diretamente da capital nacional. Mais do que apenas perceptível a presença do Estado argentino até suas fronteiras, descreveu-se como um exemplo de política pública a ser seguida pela lado brasileiro, como escreveu Othon D’Eça, criticando o abandono visível e vivido pelos brasileiros que eram absorvidos pelo lado argentino. O contraste da situação, faziam os brasileiros recorrerem regularmente ao lado do rio para acessar os serviços públicos no País vizinho: "Juiz de paz, Jefe de lo Resguardo, professores, comissários de polícia e até os severos policiais de grandes bigodes e espadagão à cinta, tudo isso vem de Buenos

\footnotetext{
${ }^{122}$ General Dionísio Cerqueira e Barão do Rio Branco envolveram-se em disputas tentando capitalizarem para si, a organização e solução do processo de arbitragem da fronteira com Argentina em 1895 que ocorreu nos EUA. As fricções das relações dos dois naquele caso poderia ser um interessante exemplo da discussão que Bourdieu (2003) faz a respeito de quem se apodera da autoridade para instituir a região (ou outros espaços, obviamente). Em Santa Catarina, Dionísio Cerqueira, município que faz divisa com o paranaense Barracão (na 'tríplice') fronteira com o município argentino de Bernardo de Irigoyen.
} 
Aires ou das províncias a 'serviço de la frontera' e portanto, a serviço da Nação argentina." (D’EÇA, 1992, p.107).

As pessoas buscavam abastecimento no mercado argentino e não eram descritas nem como argentinos, nem como catarinenses, estavam em uma situação de (como nomeia um dos autores: "paradoxo" da) fronteira. O território era brasileiro, mas a maior parte do abastecimento não: "Um kilo de café, vendido em latas com rótulos argentinos, moído em Buenos Aires, custa 10\$; [...] uma cerveja, sendo a única que ali se encontra da fabrica Qilmes, dos arredores de Buenos Aires, 4\$500; uma caixa de phosphoros, tambem argentinos, \$500 [...].” (COSTA, 1929, p.39).

Mas, a fronteira não era apenas com outro Estado-nação, e sim também com um vizinho dentro do País. Por isso, o caso do telégrafo relatado no livro de Costa (1929) torna-se relevante para a análise aqui discutida, embora parecesse frustrante para as autoridades de Santa Catarina a epoca participantes da expedição, porque o fato descrito em relação ao telegrafo repetiu-se com relação com outras instituições, seja ela as Escolas, os Cartórios e até mesmo o Exército; assim constata Arthur Costa (1929, p.47) em uma interpretação que visava mudanças: "Há, entretanto, em relação às denominações dos povoados catarinense e paranaense, uma confusão que é preciso corrigir e aqui vai a denuncia para conhecimento de quem competir." E o narrador, detalha a análise em uma área bastante confusa a quem se pertence, inclusive para as próprias pessoas de Dionísio Cerqueira:

Pois bem, a estação telegráfica desse povoado, [Dionísio Cerqueira], situado em território do nosso Estado, tem a designação de Barracão. Isso levou-nos a reclamar do agente contra tal erro e ele, justificando-se, mostrou-nos o material telegráfico recebido, inclusive carimbos, no qual estava o nome Barracão. Mostrou-nos um Oficio do Telegrafo, dando àquela estação a designação Barracão. A estação catarinense deve ser denominada Dionísio Cerqueira. A paranaense, aonde existe um radio, esta sim, seja Barracão. (COSTA, 1929, p.4748). [destaque negrito feito por mim]

Já a respeito de Chapecó, esse mesmo autor vai sugerir nome para um município que passe a ser desmembrado desse, pois considera a área territorial total bastante elevada. ${ }^{123}$ Fica claro o interesse de fazê-lo território usado. Um tamanho muito grande

${ }^{123}$ A comparação com a Rússia, chancela a tese de João M. Ehlert Maia (2008). Afinal, para Costa (1929, p.34) Chapecó "É a Russia catharinense." Dados colhidos pelos participantes da Viagem foram largamente repetidos, como fez Carlos Humberto Corrêa (1997, p.183) quando menciona a área do município de Chapecó na epoca da Viagem de 1929 como a metade do tamanho da Bélgica; tal comparação está presente em Arthur Costa (1929, p.32): "Para termos uma ideia comparativa do tamanho dessa área municipal, consideremos que a Bélgica tem apenas pouco mais de 33.000; a Suíça 41.000; a Dinamarca, 44.000 [quilômetros quadrados]." 
do espaço a ser administrado, era visto como risco de surgimento de pontos autônomos e independentes. Seria mera coincidência que Chapecó em 1943 seria desanexado de Santa Catarina para constituir o Território Federal do Iguaçu? Ainda em 1929, fazia-se a proposta de sub-divisões daquela imensa Chapecó que estimavam com área de quase $14.000 \mathrm{~km}^{2}$ e um habitante por $\mathrm{km}^{2}$. Sugeriu-se um nome ao novo município em homenagem a uma autoridade tão importante para a região, tal como fora Dionísio Cerqueira. Lembra que a homenagem àquele que fez o voto de arbitragem em favor do Brasil, na causa da disputa com a Argentina (na "Questão de Palmas") o presidente estadunidense Gover Cleveland, era o que nomeava um município paranaense chamado, Clevelândia. Mas enfatizava a relevância, do considerado pela literatura especializada (SANTOS, 2012; HENRICH, 2010) um dos fouding fathers da nação brasileira. Propunha homenagear Barão do Rio Branco, ao nomear alguma nova área a se desmembrar de Chapecó, como defendeu: "Deve caber aos catarinenses perpetuar o nome de Rio Branco em um dos melhores, mais prósperos e formosos rincões de Chapecó." (COSTA, 1929, p.47). Nesse caso, a referência ao Barão como um dos homens mantenedores da integridade territorial do País é clara, no caso brasileiro, bem poderíamos nominar também aqueles considerados "heróis territoriais".

José Boiteux (1931, p.08) também vai fazer menção a nomes de políticos e daqueles que estamos considerando de: "heróis territoriais", ou seja, figuras da cultura política do País que são representados em uma perspectiva positivista, como responsáveis pela dimensão e união de todo espaço brasileiro, nomes consideravelmente bastantes utilizados para nomear municípios e toponímias em geral. Senão, vejamos. Na passagem pelo Planalto Norte catarinense, Boiteux (1931) descreve a importância do Conselheiro Mafra ${ }^{124}$, que fez um longo laudo ou tratado jurídico para defender Santa Catarina como advogado, na disputa com Paraná no Supremo Tribunal Federal. Fora dado seu sobrenome à uma área (município) fronteiriço ao paranaense. Ainda, seguindo o relato desse trecho da Viagem, percebe-se a mobilização da identidade entre Paraná e Santa Catarina que estaria, naquela ocasião, na comemoração do centenário do início da imigração alemã para o Brasil, colonização acentuadamente marcante nas regiões

\footnotetext{
124 "Conselheiro Mafra" também nomeia uma das ruas mais movimentadas e conhecidas de Florianópolis (em que se localizam, por exemplo, o Mercado Público Municipal, a Praça da Alfândega e parte da Praça XV de Novembro). Corta boa parte do centro da capital e está localizada paralela a rua Felipe Schmidt. Destaque para a obra Manoel da Silva Mafra (2002) "Exposição histórico-jurídica: por que do Estado de Santa Catharina sobre a questão de limites com o Estado do Paraná, submetida, por accordo de ambos os Estados, à decisão arbitral pelo advogado Conselheiro Manoel da Silva Mafra.” Ed. fac-similar. Florianópolis: IOESC, 2002.
} 
fronteiriças aos municípios de Mafra e Rio Negro, esse último já em terras paranaenses, mas que a comitiva também resolvera passar, saudando a comemoração, e o autor, lembrando o histórico da personagem que nomeava aquela área catarinense, relatava:

A meia noite, encaminhamo-nos para a estação da Estrada de Ferro de S. Francisco do Sul a Porto União, afim de tomarmos o trem especial que, ás 8 horas da manhã de 19, alcançava a sede do município de Mafra.

Nesta cidade, que se condecora com o inesquecível nome do eminente jurisconsulto e ilustre catharinense conselheiro Manoel da Silva Mafra, advogado que foi da terra natal na questão de limites com o Paraná, foram examinadas as obras de construção do edifício da Colectoria, agora já inaugurado e da grande ponte que liga aquela cidade é do Rio Negro. Visitamos a exposição comemorativa do $1^{\circ}$ centenário da colonização naquele prospero município paranaense [...]. (BOITEUX, 1931, p.12-13).

As análises dos nomes já existentes, ou avaliação de remarcação das toponímias eram acompanhadas de classificações dos lugares, quase sempre reforçando um imaginário encantador e bucólico do Sertão ou, em oposição, traduzindo a ideia de um "nome natural" de áreas sem relações sociais civilizadas e sim baseadas na violência e disputas bárbaras. $\mathrm{Na}$ interpretação do autor de "O Oeste Catharinense: visões e suggestões de um excursionista", os afastados rincões eram vítimas do banditismo e movimentos revolucionários. Repete-se na sua classificação, a imagem da solidão de um vasto deserto, mas acredita ser possível desenvolver potencialidades de atratividade de bens modernos. Dos trechos de avaliações de áreas presentes no texto, torna-se possível identificar alguns dos imaginários do Sertão no Brasil, entre eles o diagnóstico de potencialidades e serem desenvolvidas.

A forma como descreve uma localidade, de Irahy, por exemplo, chama atenção ao positivar a importância da ida para morar no local, de um ex-participante nas lutas da Guerra do Contestado (1912-1916). Irahy faz parte do veio da uma área de águas termais subterrâneas e o relato de Costa (1929) enfatiza os potenciais já existentes e sinaliza futuramente serem explorados, com sentido de valor contido (valor do espaço) (MORAES; WANDERLEY, 1988, p55), mas que precisaria ser qualificado em infraestrutura, "salvando" da condição de isolamento e integrando-se à outras regiões. Tratase de análise que visa projetos de valorização criada (valor no espaço), ${ }^{125}$ quase sempre pensados de fora e preparando o mesmo não para os moradores, mas para aqueles a poderem se beneficiar dos serviços ou migrarem, atraídos, por exemplo, pela águas

${ }^{125}$ A interpretação de valor no espaço refere-se ao trabalho realizado e depositado no mesmo, "espaço receptáculo da produção material": ou valores criados. As formas preexistentes, a "natureza", por exemplo ou realidades físicas de suas características, são os valores do próprio espaço. A discussão está em Moraes e Costa $(1988 ; 1984)$. 
termais. O autor mencionou o que nominou como um Cavalheiro de algum episódio (ao qual não menciona de qual se trata) da época da Guerra no Contestado, que interessado pelas qualidades bem-fazeijas e saudáveis das termas resolveu viver por onde justamente os governadores dos Estados vizinhos (Rio Grande do Sul e Santa Catarina) estavam assinando um convênio de cooperação entre as respectivas polícias.

A nomeação da localidade de Irahy, escreveu Arthur da Costa (1929) foi dada pelos indígenas devido a estância de águas especiais, significando na língua deles água de mel e nessa estação balneária, impressiona-se o narrador, já havia um hotel em funcionamento. $\mathrm{O}$ membro da comitiva relata seu conforto, dizendo se deliciando ${ }^{126}$ nas águas do local, principalmente pelas condições da abstenção de banho, já que se encontravam no Sertão passando por situações de privação de conforto e oferecimento de serviços. Vale aqui registrar como "Antes de ser paisagem para ser contemplada, o território é um sistema material para usar porque foi construído com valor de uso." (RAFFESTIN, 2009, p.33). Assim, descreveu-se como a amenidade atraia pessoas a viverem por onde passava a comitiva:

Em Irahy, por exemplo, cujas águas são do mesmo lençol [das águas termas de Chapecó e do Rio Grande do Sul], reside José Vaccariano, nome ligado a certo episódio do ex-Contestado à construção da picada MondahyBarracão.

Contou-nos este cavalheiro que, estando gravemente doente, aconselharem-lhe as Águas de Mel.

Deu-se tão bem com ela que para ali mudou a sua residência e hoje se sente completamente curado. (COSTA, 1929, p.22).

Se o trecho acima, quando menciona o participe das batalhas no Contestado é positivado (provavelmente por ele ter sido um dos membros civis que atuaram no lado das tropas oficiais das armas do Estado), no mesmo texto o autor anuncia regularmente ter passado por região levas de desordeiros, como os roubadores de gado e participantes de movimentos revolucionários. Na "Picada de Mondahy ao Pepery" o autor lamenta o trajeto pela mata fechada que faz a ligação, desde a divisa de Santa Catarina com o Rio Grande do Sul até a Santa Catarina com o Paraná. A constante repetição de paisagens

\footnotetext{
${ }^{126}$ Marcelo Lopes de Souza (2009, p.62) bem lembra como não são nada desinteressados e imparciais os relatos de ufanismo da natureza e de idealização de bens que costumam a ser levantados pensando em transformá-los em recursos: "Exaltar esses recursos e essas riquezas, das jazidas de minérios às belezas naturais, sempre fez parte do discurso legitimatório da qualquer Estado-nação, ao lado da insistência naturalizante sobre a 'personalidade própria e indivisível' daquele espaço (discurso-argumento contra a cobiça externa e discurso-vacina contra projetos separatistas internos)." Como também assinala Antonio Carlos Robert Moraes (2006, p.50): "Os próprios meios naturais se qualificam conforme os interesses mobilizados em sua ocupação, como mostra exemplarmente a colonização em áreas dotadas de recursos minerais valiosos." Para acompanhar uma discussão completa sobre o tema, conferir a tese de livredocência na Geografia Humana da USP: "Geografia, Capitalismo e Meio Ambiente" (MORAES, 2000).
} 
em que se encontram cruzes fincadas no chão, sendo, como diz, verdadeiros cemitérios. Resquícios de disputas ocorridas nas proximidades dessa picada, faz menção a falta de comunicação entre as forças "legais" de defesa dos Estados (unidades federativas) com a força (do Exército) nacional. Arthur da Costa (1929) narra com desapontamento o trajeto da Viagem que estão fazendo, por ter sido também grande parte o mesmo caminho feito quatro anos antes pela Coluna Prestes. ${ }^{127}$ Faz depreciação dos participantes liderados por Prestes. Comenta a confusão entre a Brigada Militar sulriograndense comandada por um tal coronel Claudino, que durante nove horas manteve conflito aberto com as - por Arthur Costa (1929) denominada - Forças legais do corpo de provisório e patriotas, comandadas pelo General Paim: atacam-se mutuamente, achando estarem em combate ao inimigo de ambos. Engano que as matas fechados do Sertão causam. Para Othon D’Eça (1992, p.104), não houve nenhuma estratégia por parte da marcha da coluna, pois "Carlos Prestes nem sabia da marcha de Paim Filho."

Athur Costa (1929) menciona que na comitiva do governador, entre as pessoas que os acompanhavam no trecho Monday - Dionysio Cerqueira havia soldados e oficiais participes de encontros sangrentos que o autor passa a narrar. Possivelmente eram esses os seus informantes do histórico de confrontos pela região [?], que mencionaram a perseguição a Luis Carlos Prestes quando morreram trinta soldados da polícia do Rio Grande do Sul e das "forças legais" das armas nacionais. "Enquanto as forças de Claudino e Paim se chocavam, estava Prestes em Dionysio Cerqueira, a cerca de seis quilômetros de distância." (COSTA, 1929, p.28). Em uma estrutura textual reforçando uma das instituições mais reconhecidas como portadoras da nacionalidade: as forças armadas do país, o autor lamenta o que descreve como confusão entre fogo amigo, caracterizando os homens armados ligados a Prestes como desertores inimigos da população local e por onde faziam suas incursões. Nas palavras do autor, o perigo de tais violências constantes, relatadas quando da passagem pela região que a torna comparável e semelhante ao Nordeste do país: "Um dos grandes flagelos do Oeste catharinense, como do Nordeste brasileiro, é o banditismo." (COSTA, 1929, p.53). [destaques negritos feitos por mim].

\footnotetext{
${ }^{127}$ Simbologias da nacionalidade, são ali descritas pela história do País, como por exemplo a passagem do inspetor de fronteiras, General Rondon em 1930 e a Coluna Prestes, como a própria publicação do IBGE (1959, p.94), por exemplo, faz: "Em 1925, mo mês de março, a famosa coluna revoltosa Prestes chegava a Dionísio Cerqueira, onde se deu o encontro com as forças comandadas pelo Gal. Paim e Cel Fulgêncio Mello, tendo Prestes conseguido evadir para o Paraguai." A passagem da Coluna Prestes também deixa toponímias, como localidade de Separação, quando dividiram as tropas de Prestes e Juarez Távora.
} 
A pesquisadora de referência do Oeste catarinense na contemporaneidade, Arlene Renk (2006) analisou como houve a necessidade de implementação de políticas públicas e mesmo de orquestração de um imaginário demovendo a representação dessa região catarinense como um verdadeiro faroeste. A própria Viagem de 1929 parece ter realizado promoção de acordos que desembocassem em menores criminalidades, como um autor - Arthur Costa (1929) - que veio sendo até agora analisando, estava exercendo o cargo correspondente ao de secretaria da segurança pública do governo estadual catarinense, na ocasião da expedição. E os respectivos governadores dos dois mais meridionais Estados do país, Getúlio Vargas e Adolpho Konder, assinaram um acordo de combate ao banditismo na área de fronteira entre Rio Grande do Sul e Santa Catarina. Para que realizasse uma efetiva atração de fluxos migratórios e venda de terras a fim da colonização, alguns obstáculos eram necessários serem retirados, "O primeiro destes esteve na associação da área à imagem de caos.” (RENK, 2006, p.55).

Certamente, pode-se notar, observando os relatórios e fala do governador, assim como desses membros da comitiva aqui analisados, como se passou a ter uma expectativa de desenvolvimento da região a partir da implementação de projetos de colonização com um campesinato eurodescendente. Observa-se argumentos defendendo tanto a vinda de pessoas para o estabelecimento de fazendas de criação como da atratividade de imigrantes, para ao constituírem núcleos coloniais repercutir também no Oeste o que havia marcado a formação social das outras regiões catarinenses: a colonização em pequenas propriedades (tais como as dos Vales litorâneos) ou a criação extensiva de gado (tais como os dos Campos de Lages). Aquelas expectativas podem já, expressar um certo regionalismo catarinense - no olhar como referência o planalto e o litoral, avaliava-se o Sertão - da Viagem de então, poderiam fazer-se projeto colocados em práticas de suas realidades para esse "Oeste em descoberta".

Basta observar, a interpretação de um cronista atual, para perceber uma ligação ou representação semelhante da dispersão de um mesmo regionalismo em Santa Catarina quando afirmou recentemente: "O modelo colonizador baseado no minifúndio, semelhante ao do leste catarinense, ensaiava algum sucesso, de forma independente [nas margens do rio Uruguai].” (MOSIMANN, 2010, p.436) No dizer da epoca, clama Arthur Costa (1929, p.71): "Essas ótimas terras precisam ser povoadas de colonos e de gado. Que riqueza imensa está sendo ali inaproveitada." Identificava-se fundos territoriais a fazerem então, parte do território usado por Santa Catarina, talvez não seja mera coincidência o fato de durante a gestão de Adolpho Konder a erva-mate tomar 
“impulso como importante produto do comercio catarinense." (VIEIRA FILHO, 2001, p.22).

A ideia de implementação de uma paisagem européia começa a ser idealizada para o Oeste, quando se enfatiza a instalação de companhias de colonização de terras, como afirmou Othon D’Eça (1992) a respeito da instalação da sede do escritório, de uma dessas empresas de venda de lotes e propriedades. "Só agora vim a saber a espécie de construção que se vai erguendo no alto de um morro, em [localidade de] Passarinho. É a futura casa para a direção da colônia. Acastelada, com ameias e blockhaus, dominará uma vasta extensão do [rio] Uruguai e emprestará àquela paisagem um ar medieval." (D’EÇA, 1992, p.48).

No relatório anual do governador, do ano de 1928, Adolpho Konder dava a entender que as terras do Oeste já se encontravam em propriedade de muitas companhias colonizadoras e que o incentivo estadual para fixação de imigrantes já não era tão necessário. Realizavam-se colonizações por si mesmo, sem mais necessário apoio direto do Estado. Vai defender, nessa fala um ano antes da Viagem, como o principal problema de Santa Catarina não era mais de atração de colonização, mas de meios de escoamento da produtividade e acesso aos mercados: "Assim, o antigo problema do povoamento do nosso solo acha-se, nos dias atuais, substituído pelo problema do transporte, da viação econômica, problema esse que há merecido a minha melhor atenção.” (KONDER, 1928, p.77).

É claro ao analisar esses relatos de epoca, como também já se percebe estarem sendo definitivamente colonizadas algumas das áreas do Oeste percorridas pelo grupo do governador. Um autor compara como nas duas margens do Rio Uruguai, há diferenças de colonização em relação ao Rio Grande do Sul e em Santa Catarina, pois "[...] enquanto que o governo riograndense conserva as suas [terras] completamente devolutas" (COSTA, 1929, p.18), retardando, portanto, o uso desse estoque territorial,

$\mathrm{Na}$ margem catharinense, a contar de alguns anos, vêm-se formando núcleos coloniais muito apreciaveis, como Palmitos, São Carlos, Cascaes, Mondahy, antes Porto Feliz, Itapiranga, inteligentemente explorados pelas empresas Sul do Brasil e Chapecó-Pepery Limitada. (COSTA, 1929, p.17-18).

Ademais, de uma forma ou de outra, essa primeira e inicial colonização eurodescendente também ajuda na categorização do Oeste como Sertão inculto, pois quando logo aparecem os iniciais clarões na mata e a fixação da territorialidade de núcleos coloniais, faz-se avaliação do entorno maior e se percebe a presença de cobertura vegetal, manutenção de florestas, portanto, "de Sertão" ainda predominante 
no conjunto maior da região. A respeito de Monday, por exemplo, vai mencionar como em oposição ao Sertão a: "Colônia fundada em mata aberta há sete anos, encontramos ali traços fortes de civilização, pela organização do trabalho, sistematização das energias, ordem admirável." (COSTA, 1929, p.18).

A perspectiva de futuro para o Oeste - que os participantes que escreveram da Viagem - atribuíram à região, estava fortemente embasada na possibilidade de reproduzir as formas de desenvolvimento territorial das demais regiões catarinenses, de formação social fortemente marcadas pela colonização (imigração em pequenas propriedades de terra) européia e pelas estâncias e fazendas de criação ganadeira; a expectativa era que nesse Oeste as duas formações sociais se repercutissem, em nome da superação do Sertão, para tanto, como bem lembra Arlene Renk (2006, p.55) "Vencer o caos e impor a ordem para chegar ao progresso era o imperativo."

Mas, afinal, quem foram os relatores desse Sertão até agora debatidos, analisados e colocados suas representações dessa região? Pode ser interessante entender um pouco mais de quem se tratava. É o que se apresenta no tópico a seguir.

\section{(Auto-)constituidores, (desbravadores) do Sertão, não-geógrafos, mas "temáticas geográficas"}

Nessa parte do texto, trata-se justamente de apresentações das três autoridades, assessores ou, na expressão de Arlene Renk (2006, p.58), daqueles coadjuvantes. Foram estabelecedores da epopéia de 1929 em escrita, em discursos reconhecido como válido ou em comunicação letrada. Ao acompanharam o governador da época aos interiores de Santa Catarina, o que na interpretação de um deles foi uma longa e áspera travessia (BOITEUX, 1931, p.26); ou ainda um reforço de uma pretensa missão bandeirantista: “Há um fim alto e nobre a cumprir e nós viemos [ao Oeste] para vencer” (D’EÇA, 1992, p.48); para outro tratou-se de um exemplo de conquista, de "entradas" e de reforço do nacional:

Essa jornada, verdadeira 'bandeira' empreendida no dias que vivemos, tem características de coragem, de ousadia, de resistência, de abnegação, que lembram os gestos dos nossos maiores, quando se internavam pelos sertões, desbravando o desconhecido e levando aos rincões mais afastados o cunho da conquista brasileira, assegurando pela posse largos domínios para a nossa nacionalidade. (COSTA, 1929, p.07). [destaques em negrito feito por mim]

Ao invés de tratar tal evento - a Viagem do Governador - como uma lenta, demorada, complexa e possivelmente até, "atrasada integração", repercutiu-se antes, a 
ideia de heroísmo por ter se submetido a condições de risco; desbravando áreas e conquistando comunidades. Como se vivendo a experiência da simultaneidade de um desbravamento, esse é o um caso de um típico exemplo de discurso do pioneirismo, afinal, como parece ter dito Adolpho Konder, governador "de Santa Catharina: Aquela região dá impressão de que é de quem ali primeiro chegar." (BOITEUX, 1931, p.25).

Antes de fazer uma observação mais detidamente sobre cada um dos autores aqui citados e por último do governador Adolpho Konder, faço a referencia a seguir de suas obras sobre a Viagem, pois como aqui foram tratados como objetos centrais da análise, para que fique claro ao leitor de qual obra está se tratando. Mais a frente penso que essa sistematização ajudará a visualizar as diferenças entre os autores dos textos.

Dos livros, é importante dizer, de uma deles acessei apenas a segunda edição (D’EÇA, 1992), publicada no centenário de nascimento do autor, não conheço a primeira edição que já não se encontra em circulação e escasseia mesmo em arquivos. Como há uma folha de rosto dos outros dois livros de epoca, coloco a seguir as capas dos mesmos (imagens $\mathrm{n}^{\circ} 3$ e $\mathrm{n}^{\circ} 4$ ). Os demais documentos mencionados ao longo do corpo do texto, seguem a definitiva regra, estarão todos localizados nas referencias finais completas, inclusive, também, esses títulos que seguem:

BOITEUX, José Arthur. OESTE CATHARINENSE (De Florianópolis a Dionísio Cerqueira). Conferência realizada no Centro Catharinense, na Sociedade Geográfica (Rio de Janeiro) e no Club XII de Agosto (Florianópolis) em 1929. Florianópolis: Livraria Central de Alberto Entre e Irmãos, 1931. 28 páginas

COSTA, Arthur Ferreira da. O OESTE CATHATINENSE. Visões e suggestões de um excursionista. Rio de Janeiro: Villas Boas Cia., 1929. 74 páginas

D'EÇA, Othon. AOS ESPANHÓIS CONFINANTES. 2 2a Ed. Florianópolis: Fundação Catarinense de Cultura/FCC; Ed. UFSC/; Fundação Banco do Brasil/FBB, 1992. 154 páginas. 
Imagens 11 e 12: Capas de publicações de livros de época da expedição ao Oeste de 1929

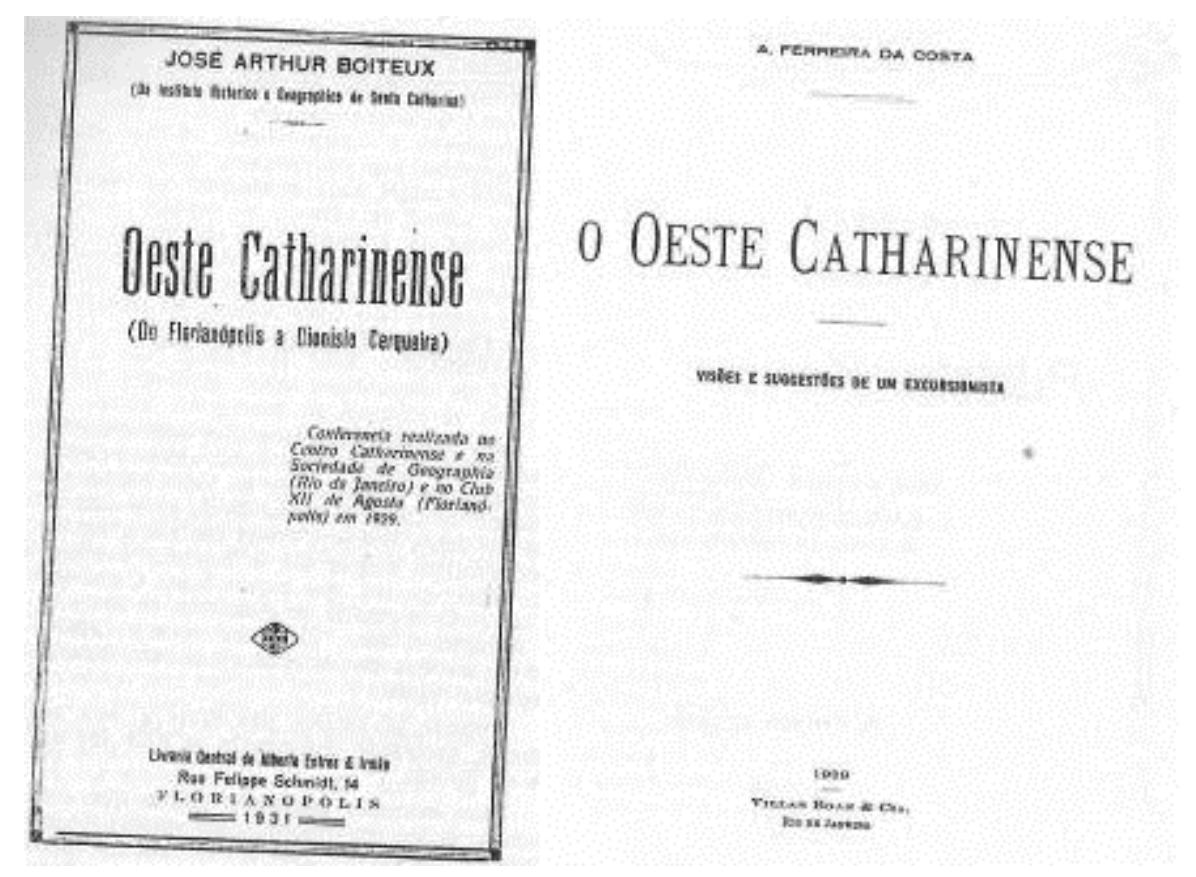

A seguir, apresentado um apanhado das ações e delimitações biográficas visando entender quem são esses funcionários de Estado e autores desses textos. Utiliza-se para tal principalmente o "Dicionário Político Catarina" (PIAZZA, 1994), buscando dar ênfase nas suas vinculações com discursos geográficos e de constituição de comunidades imaginárias, evitando para isso, seguir uma ordem cronológica das suas realizações, mas focando na temática que possa envolver diretamente com a Viagem. Tento a seguir, falar de suas biografias mais no contexto da expedição, do que fora dela.

*A "biografia" de José Arthur Boiteux (1865-1934; natural de Tijucas/SC), permite interpretar pistas interessantes, a respeito da disseminação do discurso geográfico que após a segunda metade do século XIX é tônica forte no Brasil (MORAES, 199, p. 170). Ele foi autor de títulos de obras com abordagem temáticas de vulgarização ou divulgação de cunho geográfico, como por exemplo: "Diccionário histórico geográfico do Estado de Santa Catharina”, publicado no Rio de Janeiro em 1915, primeiro volume e em 1916 o segundo volume, assim como no final do século XIX havia publicado o: "Santa Catharina-Paraná: questão de limites", também no Rio de Janeiro (editora T.A Tribuna) datado de 1890.

Um dos membros fundadores do Instituto Histórico e Geográfico de Santa Catarina/IHGSC que data de 1896 e da Academia Catarinense de Letras em 1920, o que mais reforça ainda a hipótese de Antonio Carlos Robert Moraes (1991, p. 170) de que os 
discursos geográficos no Brasil antecipam-se aos departamentos de cursos de Graduação de geografia ou, que a institucionalização desse campo como uma comunidade estritamente de geógrafos-profissionais - lembra esse autor - passa a se constituir pós anos de 1930. Mas já ocorria, então antes do primeiro governo Vargas, a busca constante por debates de temário envolvendo a geografia, como pode-se exemplificar com o relatório anual ao governador em 1927, que menciona a ida de Boiteux como representante oficial do governante do Estado catarinense a um evento geográfico de então, realizado no estado de Espírito Santo:

$8^{\circ}$ Congresso de Geographia

A 23 de outubro, foi nomeado o Desembargador em disponibilidade José Arthur Boiteux, para representar o Estado no $8^{\circ}$ Congresso de Geografia a realizar-se em Victória, em novembro.

(RELATÓRIO ao governador. 24 de agosto de 1927 por Cid de Campo)

Muitas das discussões de temáticas (ou de ideologias) geográficas eram realizadas por bacharéis, como era José Boiteux. Ainda, sobre aspectos de sua trajetória, vale assinalar que assim como seu irmão Henrique Boiteux (um Almirante que participou no apoio de Floriano Peixoto na Revolta da Armada), teve seus primeiros estudos em Tijucas com um professor particular belga, Feliz Vaes. Fez uma carreira bastante acentuada na política e como funcionário de Estado, seja na esfera federal ou em Santa Catarina. Cursou até o segundo ano de Medicina no Rio de Janeiro. Mas bacharelou-se, posteriormente, em 1911 na Faculdade Livre de Direito do Rio de Janeiro.

Com a República, foi nomeado oficial de gabinete do Governador Lauro S. Müller. Organizou a Seção Estatística e Comercial de Santa Catarina, ocupando em seguida, função parecida, na Prefeitura do Rio de Janeiro. Teve vários mandatos tanto como deputado e secretário de Estado em Santa Catarina (como por exemplo, Secretário do Interior e de Justiça entre 1918-1920). Foi nomeado Juiz de Direito e Desembargador do Tribunal de Justiça do Estado em 1922 (PIAZZA, 1994, p.120).

Tendo sido um dos secretários do governo Adolpho Konder, participou como tal da expedição ao Oeste, tendo seu nome dado a escola fundada ${ }^{128}$ pelo governador em

\footnotetext{
${ }^{128}$ Arthur Costa (1929, p.40), também relatou considerar a escola de fundamental importância para o sentimento de nacionalidade nessa área de fronteira: "Entre as numerosas providencias de repressão de crimes, asseguração de garantias, aparelhamento judiciário e administrativo, criou o presidente Konder uma escola pública, a que deu o nome de José Boiteux, colocando-a sob o patrocínio deste digno catarinense, com moldes correspondentes a essa alta mentalidade que tem o atual governo de bem organizar as nossas repartições e instituições e eleger funcionários destacados para que, ali, no confronto da fronteira, o sentimento nacional não sofra constrangimento."
} 
Dionísio Cerqueira, durante a Viagem, fato que ele comentou no seu discurso publicado em 1931 e que mais uma vez reforça a junção entre formação territorial, ideologias geográficas, regionalismo e apropriação do espaço: "Criou-se a escola, que tomou o nome de José Boiteux. Não mais deixarão nossos conterrâneos de aprender a língua nacional, pois que, para não serem analfabetos, iam a escola argentina, atravessando o [rio] Pepery-Guassu.”(BOITEUX, 1931, p.24).

*Othon D’Eça (1892 - 1965) é natural de Florianópolis, a ele é atribuído como quem lançou - se não ele apenas, mas entre os iniciadores - a ideia de criação de uma Academia de Letras catarinenses, ao qual mencionado acima ter participado José Arthur Boiteux. Tem uma das suas obras mais conhecidas em Santa Catarina o título publicado pela imprensa oficial do Estado catarinense em 1957: "Homens e algas.” Em 1920, com mais dois amigos lançou a revista mensal Terra, e a partir de 1923 no jornal "A republica" de Florianópolis, iniciou uma publicação de uma novela, nesse mesmo ano forma em Direito no Rio de Janeiro. Em 1926 foi nomeado juiz na comarca de Campos Novos. Embora trajetória de administrador/jurista publico, também dedicou-se à narrativa e a relação com o mundo das letras.

Tendo escrito o livro de maior número de páginas de todos os três, certa altura da Viagem de 1929, Arthur Boiteux (1931, p.14) mencionou D’Eça como sendo o Pero Vez de Caminha da comitiva, tal comparação aponta mais uma vez para a ideia de descoberta, desbravamento e conquista desse (novo) Sertão/Oeste de Santa Catarina. ${ }^{129}$ Já Arthur da Costa vai relatar quando da passagem do governador Konder pelo Oeste, um caboclo veio solicitar ajuda em um caso de enfermidade. O próprio médico de comitiva, afirma o autor do relato, também se encontrava em muita febre e por isso, é enviado Othon D'Eça no lugar dele à residência de morador solicitante de ajuda. Costa (1929, p.61) ao fazer a descrição daquele fato, faz menção ao sobrenome de origem nobre: “Os Gama d'Eça são fidalgos, descendentes, por linha bastarda, de Pedro, o Cru." Ao que parece, na Viagem de 1929 há entre os autores, uma referencia como se estivessem reproduzindo a chegada dos portugueses em caravelas ao Brasil, como que reforçando a máxima de estarmos "Num país onde, de tempos em tempos, se tem a

\footnotetext{
${ }^{129}$ Na seguinte passagem: "Desde Passo Borman que o panorama se desnuda um revelação maravilhosa de belezas. A estrada porém é sempre em descida. Há um trecho, porém, beirando umas rochas a pique, que Othon d'Eça, - o Pero Vaz de Caminha da Bandeira Catharinense no século XX, - classificou de colunas de um templo indígena, referindo-se igualmente a umas pedras de feitios esquisitos, que pareciam crescer dentro da neblina fumarenta que apagava a paisagem em torno." (BOITEUX, 1931:14).
} 
sensação da redescoberta [...]" (OLIVEIRA,2002, p.518), entretanto, a essa referência é agregada o imaginário dos também "descobridores": bandeirantes. Na constituição de si mesmos, esses narradores tornam-se os portadores da civilização (e das salvações) em meio ao Sertão, se pensam como responsáveis pelo futuro uso do espaço e como planejadores desses fundos territoriais. Se viam ali com um papel missionário:

Nessa noite, em meio de uma trovoada tonitroante, apareceu um caboclo.

Soube da passagem do presidente e vinha pedir auxilio do membro da comitiva para pessoa de sua família, gravemente enferma.

O medico, dr. Manoel Xavier, nosso companheiro de jornada, ardia em febre de 40 graus.

Improvisou-se, então, em esculápio o dr. Othon Gama d'Eça.

$\mathrm{O}$ acadêmico, poeta, jurista e beletrista arvorou-se humanitariamente em Hipocrates, e lá se foi, pela noite a dentro, através de ínvios atalhos, sob o trovão e a chuva, com uma malinha de medicamentos - a que havia trazido o dr. Xavier - á casa do caboclo, num percurso de duas léguas.

$[\ldots]$

O fato é que, cerca de meia noite, quando já dormia o barbaquá, regressou o ilustre descendente de Pedro, o Cru, molhado como um pinto, a pedir cachaça.

Lá fora, o caboclo renovava-lhe reiterados agradecimentos pela sua intervenção que havia salvo a doente...

(COSTA, 1929, p.61).

A Othon D'Eça é atribuído pelos outros dois narradores, como se o mais atento observador e detalhista. Sobre sua trajetória é importante mencionar que recebeu em 1935, o diploma de docente livre em Direito Público Internacional pela Faculdade de Direito de Santa Catarina e em 1953 recebe o diploma de Catedrático de Direito Romano pela mesma Faculdade. Em 1948 fora nomeado Secretário de Estado dos Negócios da Segurança Pública de Santa Catarina, cargo que na epoca da Viagem de 1929, ocupava Arthur da Costa, cujo resumo biográfico é feito a seguir.

*Arthur Ferreira da Costa dos três autores da Viagem, é o único não natural de Santa Catarina e o que por agora, menos informações consegui recolher até o momento. Nascido em Santo Amaro da Purificação/BA em 1887. Assim como os demais, fez carreira no Estado e bacharel em Direito (na Bahia) como Costa e Boiteux. Veio do seu estado natal para Joinville (SC) em 1908 e ali atuou na advocacia e na polícia. Elegeu-se deputado mais de seis mandados em Santa Catarina e eleito também Senador (ocupando tal função durante os anos de 1935-1937). Exercia o cargo de chefe de Polícia do Estado no mandato de Adolpho Konder quando fez parte da comitiva da expedição ao Oeste, motivo pelo qual seu relato é mais atento e descritivo da criminalidade, "banditismo" e 
lutas (guerras) no Oeste. Entre os três, é ele quem mais se dedicou a detalhar a assinatura do plano de apoio mútuo de combate ao banditismo de fronteira assinado entre Getúlio Vargas e Adolpho Konder em 1929, às margens do Rio Uruguai.

\section{O Bandeirante (brasileiro-germânico) a nacionalizar o Sertão: Adolpho Konder}

Uma das mais fortes representações de Sertão no Brasil, entende-o ou descreve como ambiência em que se gesta a verdadeira brasilidade. A ideia do Sertão que acolhe a nacionalidade - como bem historicizou Ricardo de Oliveira (2002) no relevante artigo: "Euclides da Cunha, Os Sertões e a invenção de um Brasil profundo" - o livro Os Sertões parece ter impactado decisivamente na formalização de mitologias da brasilidade sertaneja; não seria curioso questionar, afinal, se há uma imensa caracterização do Sertão como guardião das mais profundas raízes brasileiras, por que em Santa Catarina do final dos anos 1920 o projeto de conquistá-lo teve a meta de nacionalizá-lo? Talvez hoje, possa ser hegemônica a idealização do Sertão-nação brasileiro, mesmo em Santa Catarina. Mas na epoca aqui tratada, as representações do Sertão parecem ser justamente o inverso da afirmativa: "Falar em sertão significa falar em brasilidade." (OLIVEIRA, 2002, p.518).

Certamente houve - como aborda a literatura sobre o tema - uma passagem bastante sensível da simples representação do Sertão barbárie, para a representação do Sertão como uma sociedade, em que passou-se a acreditar que os brasileiros do interior não seriam tão degenerados (não teria ocorrido tanto cruzamento de raças como no litoral) e, para reproduzirem a vida em um meio tão hostil e inóspito, necessitavam serem antes de tudo, fortes. (OLIVEIRA, 2002, p.523).

Devido também a maior lentidão da chegada da modernidade, assim como dos costumes e sociabilidades exóticas quando vindas do estrangeiro, eram mediadas (pela litoraneidade e) pela própria distância do interior, o que tornaria a vida sertaneja autêntica e resultada de um fruto do próprio meio. Livre das influencias e modas externas, seria a melhor espacialidade para reprodução de uma nacionalidade pura. Ricardo de Oliveira (2002) bem argumenta como o impacto da obra de Euclides da Cunha teria auxiliado na realização das alterações das representações do Sertão incivilizado, para a imagem da tipicidade e mesmo no "processo de invenção de uma paisagem nacional [...].” (OLIVEIRA,2002, p.521). Para esse autor, após Euclides da Cunha, se vulgarizou uma ideia de pureza e essência do Sertão, forjador também de uma 
gente original e "que no imaginário de uma geração, passou a expressar a alma nacional" (OLIVEIRA, 2002, p.525). Inclusive passando a ser exemplo para os nãoSertões a melhor forma de ser da brasilidade, como "É o caso dos intelectuais estadonovistas que ressaltam a autenticidade e a originalidade presentes na vida sertaneja, as quais deveriam guiar um novo projeto nacional para o país, que teria por eixo central a incorporação dessas terras e suas riquezas." (MORAES, 2009, p.92).

A partir dessa reflexão é de se sugerir hipóteses, questionando aqueles levantamentos e textos ${ }^{130}$ que tenham justamente realizado reflexão diferente, tal qual as que buscaram caracterizar o Sertão em Santa Catarina como carente de nacionalidade brasileira e portanto, não como originalidade nacional. Artur da Costa (1929), por exemplo, afirmou que embora Adolpho Konder esteja realizando desbravamento naquele ano de 1929, essa tomada do Sertão já deveria ter sido realizada logo após o acordo assinado (em 1916) entre os governadores do Paraná e Santa Catarina, quando no ano seguinte suas respectivas casas legislativas endossaram legalmente a linha demarcatória da divisa. Vai interpretar a demora da tomada de posse por parte dos governantes catarinenses, como um risco da desnacionalização, pois:

Esta providencia [de ida pessoal de um governante de Santa Catarina ao Oeste] deveria ter sido adotada pela lei 1147 de 1917, logo após a legalização do Acordo [entre Paraná e Santa Catarina], quando também deveria ter ido até ali o próprio chefe ou, pelo menos, alto representante do governo de então, realizando a obra bandeirante que vem fazer o presidente Adolpho Konder, abrasileirando e acatharinando aquele rico sertão e aquela linda cobiçada [Extremo-Oeste e região de Chapecó]. (COSTA, 1929, p.34).

É certo que para os olhares dos que se consideravam desbravadores, muitas identificações foram feitas sobres os Sertões que percorrem no Oeste; menores foram efetivamente os símbolos e aspectos relacionados a Santa Catarina ou de outras partes do País que pela região - desejavam ver - mas, não encontraram. Os autores registravam relações de pertencimento: da nação argentina; do Estados do Paraná e/ou Rio Grande do Sul e mesmo de imigrantes de origem alemã que se encontravam nos símbolos e referencias das populações daquele Sertão catarinense.

O questionamento que estou propondo realizar é se a própria mobilização da ideia desse Sertão a ser abrasileirado, associado a outro signo forte como o Bandeirante,

\footnotetext{
${ }^{130} \mathrm{Na}$ pesquisa até agora realizada não há referência do Sertão em Santa Catarina como exemplificações de brasilidade, justamente o inverso, como segue, por exemplo: "Com seu gesto bandeirante, de difícil imitação pelo esforço, resistência e coragem que reclama, fez o presidente Adolpho Konder o descobrimento dessa zona, apreciou [sic] ao vivo as suas enormes e infinitas possibilidades e as suas prementes e gritantes necessidades." (COSTA, 1929, p.38). [itálicos como no original]
} 
teria sido uma forma de Adolpho Konder construir uma plataforma política bastante nacionalista, para um político como ele, do descendência germânica?

Sugerindo essa negociação de identidade étnica-nacional em alguns objetivos de Konder, gostaria de propor algumas reflexões inspirado nas sugestões de Jeffrey Lesser (2001), na obra: “A negociação da identidade nacional. Imigrantes, minorias e a luta pela etnicidade no Brasil." Embora talvez, nunca consigamos ter uma resposta plena, estou propondo a seguinte problemática da Viagem de 1929: as formas de nomeá-la e seus ritos; a emergência de um "espaço desconhecido" (Sertão) dentro de Santa Catarina como um problema ainda não resolvido; e o "resgate" desse fundo territorial como uma ação feita por brasileiros/catarinenses não seria todo esse processo uma espécie de ideologia geográfica com a qual o governador negociara sua identidade (LESSER, 2001)?

Teria sido a própria Viagem de 1929 uma busca pela demonstração pública e visível para demais moradores de Santa Catarina (e dos demais Estados do Brasil) não originários da Alemanha, como era também o governador, um brasileiro?

Estou sugerindo que para aqueles que procuravam caricaturas germânicas, poderiam encontrar no sobrenome Konder, em seu pai alemão (morador de Itajaí) e a própria corporeidade de Adolpho, tornando-o reconhecido entre os descendentes de alemães como um dos seus (partilhadores de uma mesma identidade de origem ou etnia). Mas aos brasileiros, além de nascimento em Itajaí, de sua mãe luso-brasileira e da língua portuguesa, haveria tal governante considerado a possibilidade de aderir e buscar mais signos de brasilidade sobre si mesmo. Teria sido aquela Viagem uma dessas possibilidades de mostrar (em um típico exemplo de negociação identitária) sua face brasileira? Estou sugerindo esse argumento, consciente de que provavelmente, em relação ao Sertão, uma constatação bastante diferente de outras regiões do Brasil foi elaborado em Santa Catarina, particularmente por ter em seu extremo uma outra territorialidade, ou seja, outro Estado-nação (Sertão fronteira). O que geograficamente não ocorre, por exemplo, na região nordeste brasileira. O impacto da fronteira e Países limítrofes, como caracteriza alguns dos Estados do extremo Oeste brasileiro de maneira geral, de uma forma ou de outra, manifesta uma comunidade imaginada nacional bastante própria e deve ser levado em consideração.

Entendo que entre as representações de Sertão que mais reverberavam nos ano 1920 no Brasil, predominava aquela que fora associada ao interior da região nordeste 
(não litorâneo). Era de Sertões assim, desertificados ${ }^{131}$ e "nordestinizado" que apareciam como dispersores da brasilidade e, provavelmente, as regiões de florestas verdes ou campos florestais do Brasil meridional não se enquadrariam completamente no detalhamento dessa representação, e mais ainda que o limite do "nosso Sertão" catarinense se encontrava com o "Sertão deles": da República Argentina. ${ }^{132}$

Estou de acordo, como podemos perceber através dos relatos de epoca, como houve a caracterização de nacionalizar o Sertão em oposição a influencia argentina, não estou, portanto, problematizando nem negando a peculiaridade dos Sertões em Santa Catarina nos anos 1920 como sendo (tendo um “caráter") e sua regionalização certamente tem - mas, sugiro a hipótese de que a eleição dos símbolos e formas de incorporação desse fundo territorial foi particularizado pelo abrasileiramento do espaço e mais ainda, pelo busca de reconhecimento da brasilidade de quem se representava colocando em prática a conquista do Oeste. Elegeram-se como "novos bandeirantes"; incorporadores de "novos espaços" à nação brasileira, mesmo que seu nome de família fosse, Konder.

Quero fazer menção a respeito da expressão que nomeou a ida ao Sertão. Após apresentar a seguir, uma discussão a respeito do governador-bandeirante; sigo fazendo algumas explanações sobre a centralidade do rodoviarismo em seu governo, fazendo simultaneamente menções biográficas de Konder e de sua trajetória política, usando para tanto, bastante da documentação oficial produzida anualmente (os relatórios ou mensagens) pelo próprio governo do Estado.

Embora me pareça bastante curioso que um filho de imigrante alemão seja um bandeirante, antes sugiro um questionamento antropológico de estranhamento do uso da expressão bandeirante, em pleno último ano da década de 1920. José Boiteux (1931, p.28), creditou ${ }^{133}$ ao - que ele chamou de jornalista conterrâneo - Tito Carvalho, diretor

\footnotetext{
${ }^{131}$ Mais uma vez faço menção ao excelente trabalho de Ricardo de Oliveira (2002, p.522): “A partir do fenômeno Os Sertões, percebe-se a delimitação do conceito de sertão articulado essencialmente à Região Nordeste e, mais especificamente, notamos algo mais significativo que foi o processo de identificação básica da ideia de sertão com a simbologia referente ao deserto (uma espécie de completa desertificação no significado da palavra).”

${ }^{132}$ Antonio Carlos Robert Moraes (2009, p.98) lembra como a noção de deserto na argentina pode muito bem ser associada ou colocada em comparativa de paralelo, em relação ao sertão brasileiro.

133 Nessa passagem: "Excursão, finalmente, que pela multiplicidade e relevância dos fins usados e já alcançados pelo cunho patriótico que os ditou, tem valido, sem favor, ao Presidente Catarinense e a todos quantos o acompanharam o titulo de BANDEIRANTES DA BRASILIDADE, na fras em sob todos os pontos de vista feliz, de Tito Carvalho, distinto jornalista conterrâneo, diretor da Republica e destacado membro da Academia Catarinense de Letras." (BOITEUX, 1931, p.28).
} 
do Jornal Republica de Florianópolis e membro da Academia Catarinense de Letras, a ideia do titulo: "Bandeirantes da brasilidade" para participantes da Viagem de 1929. Como bem lembra Antonio Carlos Robert Moraes (2000), o uso do imaginário bandeirante está fortemente associado à execução de projetos de domínios e incorporação de áreas, mas também com a manifestação de um tipo de heroísmo na identidade nacional. O próprio Euclides da Cunha,

Considerava-se um bandeirante, um filho da roça, que se mostrou bastante animado antes de partir para os sertões da Amazônia, pois achava que seria possível levar adiante este ideal; porque, não 'desejava a Europa, o Bulevar, os brilhos de uma posição', desejava 'o sertão, a picada malograda, a vida afanosa e triste de um pioneiro'. (OLIVEIRA, 2002, p.532).

Estaria no imaginário do senso comum, serem os bandeirantes um dos principais legitimadores da apropriação dos Sertões e da aquisição de benefícios à nação a partir da transformação desses fundos territoriais em espaços definitivos/conquistados. Bandeirantes seriam a mitificação de "heróis territoriais", expressão que pode nomear aqueles personagens a quem se atribui assegurarem domínios, estoque de espaço e o atual e imenso desenho do Brasil, ou no caso de Euclides da Cunha, de terem reconhecido e resguardado o melhor da brasilidade. Em Santa Catarina, Adolpho Konder pode ser considerado um desses personagens mitologizados, que as narrativas elegem como "heróis territoriais."

Nessa interpretação, a regular busca pela conquista de mais espaços, conformaria uma prática violenta de relações sociais, tendo como consequencia a prática de não reconhecer a nacionalidade nas comunidades e vínculos entre as pessoas, mas sim no espaço que a elas pertencem como membros de um Estado nação. Como já discutido na introdução desse trabalho, seria o território uma espécie de "ente agregador" de projetos, estando a população a reboque do mesmo. A figura do bandeirante casa muito bem com o apetite do controle territorial da elite brasileira, "Assim, o processo de apropriação do espaço exprime-se num tipo social específico - o bandeirante - ao qual corresponderia um tipo de organização social também peculiar: a bandeira, síntese da motivação expansionista fundante do Brasil.” (MORAES, 2000a, p.25).

Em muitas situações no Brasil, buscou-se a identidade nacional via as concepções de apropriação de espaços; um historiador em Santa Catarina relatando em retrospectiva o que ele entende ter sido a Viagem de 1929, acabou por reforçar essa centralidade do espaço na formação territorial brasileira, quando disse que Adolpho 
Konder: "Descortinando o território desconhecido buscou a identidade catarinense." (MEIRINHO, 1997, p.199). Ou seja, a própria busca de incorporar projetos de futuro ao Sertão, aparecia como uma identidade, confirmando um discurso de comunidade de interesses catarinense, por exemplo.

Mas também houve quem tivesse entendido aquela Viagem como vontade individual do governante e não das instituições do Estado; entretanto sendo o governo limitado ao tempo e "provisório", deve-se mencionar que é o Estado (e seus agentes e burocracia) quem poderiam prover os interesses das comunidades quando o governador voltasse para o Palácio Barriga-Verde, em Florianópolis. A interpretação do autor, a seguir, acabou fortalecendo mais a figura individual do político, do que os resultados que poderiam ocorrer a partir da tentativa de implementar os órgãos de governo na região; diz que Adolpho Konder "marcou, com sua presença, a unidade hoje inquestionável do Estado de Santa Catarina." (VIEIRA FILHO, 2001, p.221). Nesse caso, recolocando a figura individual (do "Bandeirante"), que personifica como agente de unificação, o desenho do território.

Defendo a ideia de que a mobilização da expressão, Bandeirante, convinha ao governador, pela: a) brasilidade relacionada ao termo; b) positivação das ações como a de agregar espaços; c) constitui um imaginário de governador heróico: desbravador, ativo e atuante; d) reforça as representações de progresso, civilização e superação da natureza atribuídos ao Sertão. Enfim, mesmo sendo um governo da segundo década do século XX, tratou-se de uma re-significação e reapropriação de um ator social da história territorial do país:

O recuo do meridiano de Tordesilhas é comumente apresentado como um feito estimulador do orgulho nacional, logo como algo como um alimento rico para a doutrinação patriótica. Toda a mitologização do bandeirante e do bandeirismo bem atestam esse fato. (MORAES, 2000a, p.25)

Tal mitologia bandeirante, articulada com ideia da necessidade do Sertão ser nacionalizado, colocava em prática uma ideia de governo realizando muitos atos com uma única viagem de um mês. Incentivava a incorporação dos fundos territoriais, solidificava uma auto-promoção (maior exposição "positiva") que interessa a qualquer governante em democracia e atribuía uma poderosa narrativa de imaginário comum aos catarinenses: a necessidade de transformar o Sertão, como já eram as demais regiões catarinenses. O Governador de Santa Catarina em 1956, quando da morte de Adolpho Konder, afirmou que foi com a Viagem de 1929, que Santa Catarina tinha feito seu encontro com seu próprio espaço, equiparado as fronteiras e as diversidades internas, 
“[...] a preocupação do ex-governador [Adolpho Konder] era dilatar as fronteiras culturais e econômico do Estado para que coincidissem com as fronteiras geográficas." (MOSIMANN, 2010, p.436). Não teria sido simbolicamente, esse o momento de tornar o Oeste catarinense integrante do território usado em Santa Catarina?

Ainda pouco mencionei da trajetória política e das ações ao longo de seu governo. Faço agora. Adolpho Konder (1884-1956) foi o primeiro governador de uma geração a não ter sido participante do movimento republicano de 1889. (MEIRINHO, 1997, p.196). Por outro lado, também é daquela geração dos que ascenderam à vida política anteriormente a Revolução de 1930. (CORREIA,1986, p.61).

Fez estudos primários na cidade natal (Itajaí), depois nas cidades de colonização alemã: Blumenau e naquela em que cursou humanidades no Colégio Nossa Senhora da Conceição, São Leopoldo (RS), onde nos tempos de estudante fora colega de Getúlio Vargas.

Bacharelou-se em 1907 pela Faculdade de Direito em São Paulo, retorna para Itajaí aonde funda o jornal "Novidades". Ingressou no Ministério das Relações Exteriores no Rio de Janeiro, ficando nesse cargo até 1913. (MEIRINHO, 1997, p.196). Nomeado pelo Governador Hercílio Luz, secretario da Fazenda, Viação e Obras Públicas do Estado, foi considerado o principal herdeiro político de Hercílio. ${ }^{134}$ No período desse governo criou-se gabinetes especificas dentro do aparato do Estado separando a administração de terras (e colonização) das estradas, como a criação, no ano de 1918, da Diretoria de Terras, Colonização e Agricultura, instituição que, até ser desmembrada, estava subordinada à Diretoria de Viação e Obras Públicas desde o ano anterior - 1917 - quando essa última havia sido criada. ${ }^{135}$ Antes do desmembramento institucional entre essas duas diretorias, estradas e colonização estavam na mesma esfera político-administrativa do Estado de Santa Catarina.

Em agosto de 1926 é homologado pelo Partido Republicano Catarinense/PRC, a candidatura de "Adolfo Konder, tendo como vice o lageano Valmor Argemiro Ribeiro Branco.” (MEIRINHO, 1997, p.196), tal chapa política pode muito bem representar a partilha de interesses tanto das elites das áreas de colonização em pequenas propriedades como as da região estancieiras que caracterizam o planalto de Santa

\footnotetext{
134 “[...] não completando seu último mandato, Hercílio Luz deixou em seu lugar, na liderança política do Estado, Adolpho Konder, seu Secretário da Fazenda e Obras Públicas, que permaneceu à testa do Partido [Republica Catarinente/PRC] até 1930.” (CORRÊAO, 1984, p.25).

${ }^{135}$ Lei n.1208 de 21 de outubro de 1918 instaurou a diretoria de Terras, Colonização e Agricultura, desmembrando-a da Diretoria de Viação e Obras Publicas. Ver: Adolpho Konder (1919, p.111)
} 
Catarina. No discurso de posse, Adolpho Konder diz ter como metas principais: "restaurar as finança públicas, desenvolver o aparelho educacional existente, construir e conservar estradas de rodagem." (KONDER, 1926, p.08). O programa de governo de Adolpho Konder de 1926 é emblemático da intensa expectativa e positivação representada no automóvel. ${ }^{136}$

No discurso publicado e lido num banquete em setembro de 1926 em Florianópolis, Adolpho Konder enfatiza que mesmo aqueles Países que possuíam extensos e bem organizados sistemas ferroviários, estavam sendo implantadas longas estradas para automóveis. Aos Países de míngua ferrovia, interpretava o governador de então, mais do que alternativa, impunha-se como solução o transporte em estradas de rodagem. $\mathrm{O}$ governador dizia assumir-se inspirado no lema estadunidense de "manter $a$ América sobre rodas" e que bem caberia a Santa Catarina adaptar-se a essa tendência, como forma de resolver os seus problemas de transporte. Inspirava ainda ao governador catarinense, o que havia realizado Washington Luís quando fora governador do Estado de São Paulo, pois: “[...] ligou, por meio de estradas de rodagem, impecavelmente construídas, os pontos cardeais do grande Estado à sua majestosa Capital.” (KONDER, 1926, p.52). Adolpho Konder dizia acreditar que Washington Luís, na presidência da República, reproduziria a toda a nação brasileira, sistema rodoviário moderno e eficiente ao que havia sido implantado em São Paulo (MARTINELLO, 2012).

$\mathrm{Na}$ década anterior, em mensagem do governador de então, também havia referência à modernidade norte-americana, mas para afirmar "o quanto humanitário" era a utilização de presidiários na construção de estradas. Desejando tornar a população carcerária em mão-de-obra na construção e conservação de estradas da Ilha de Santa Catarina, remeteu-se e era tomado, como exemplo, os Estados Unidos, sendo referência no tratamento de presos que dizia ser largamente usados na manutenção de estradas. Em resposta à solicitação da secretaria de interior e justiça do Estado de Santa Catarina, foi escrito, em 1919, um parecer favorável à utilização de detentos na construção de estradas de rodagem. Nessa epoca Adolpho Konder já era o principal secretário do governador Hercílio Luz, a quem apresentava os relatórios. Assim parece ter dito o chefe de polícia, Gil Costa, dando como exemplo bem-sucedido da prática e uso "dos apenados" na construção de estradas de rodagem nos Estados Unidos, São Paulo e

\footnotetext{
136 "Já disse um presidente brasileiro: governar é construir estradas. A frase traduz em mito a concepção das elites governamentais: o país visto como espaço (e não como nação), e um espaço que deve ser conquistado e explorado." (MORAES, 2005a, p.137-138).
} 
Minas Gerais, segundo redigido no relatório de 1919: "Estou, assim, de acordo quanto aos meios de dar à pena, entre nós, um caráter mais lógico e mais humano." (KONDER, 1919, p.124). ${ }^{137}$ Autorizado pela autoridade policial, o trabalho de presidiários na manutenção e conservação de estradas era legalmente e moralmente aceito, segundo consta no relatório apresentado ao governador em 1919. A capital poderia contar com os apenados para fazer melhoramentos de suas estradas de rodagem no interior da Ilha.

O discurso do rodoviarismo parece ter sido implantado em Santa Catarina segundo sua ênfase nos relatórios anuais - antes da esfera nacional, como é recorrente atribuição dessa meta por Juscelino Kubitschek. Por outro lado, se São Paulo aparece como referência de Adolpho Konder de um plano rodoviário bem realizado, talvez seja exagero atribuir a decisão do sistema viário pelo presidente mineiro. Observando o caso de Santa Catarina no Brasil, acredito haver um excessivo peso da escolha do rodoviarismo atribuído ao governo do Presidente JK, o maior e grande responsável pela (mono)opção em estradas de rodagem para veículos automotores. Como os livros didáticos de história do Brasil ainda continuam a mostrar, JK favoreceu aos interesses de empresas automobilísticas e não promoveu outros sistemas de transportes em paralelo. Em Santa Catarina, a opção ocorreu (no mínimo) três décadas antes da presidência de JK. Pode dizer-se que o rodoviarismo triunfa em Santa Catarina como valor de modernidade e caminho ${ }^{138}$ para a integração, sendo projetado - ao menos é o que consta nos discursos - antes da esfera nacional. A elite local no aparelho burocrático administrativo tem, nos governos de Washington Luis, a referência principal de articulador das rodovias, sinônimo de progresso.

Mas a referência aos Estados Unidos, em nível internacional, como padrão rodoviário bem-sucedido é mencionado com maior vigor a partir do governo de Adolpho Konder. Dentro do País, o destaque e inspiração é São Paulo. Na mensagem governamental, em 1929, afirmava-se, a necessidade do constante melhoramento da qualidade da rede rodoviária. Ocorriam "[...] exigências cada vez mais apuradas do automobilismo, que já entrou definitivamente em nossos hábitos, até mesmo nos das populações das regiões mais distantes." (KONDER, 1929, p.88). O fato é que, desde o início desse governo, a ênfase do discursivo do transporte e do deslocamento é atribuída

\footnotetext{
137 A frase é de Gil Costa. Relatório apresentado ao governador Hercílio Luz, por Adolpho Konder (1919), secretario da Fazenda, Viação, Obras Publicas e Agricultura, em 01 de maio de 1919.

${ }^{138}$ Por redes rodoviárias se pensava fazer a ligação litoral-Sertão como fala Konder (1927, p.87) sobre as estradas de penetração, deveriam fugir dos traçados longitudinais (norte/sul), pois buscava "[...] recorrer às estradas de rodagem para comunicar o sertão com o litoral".
} 
quase que totalmente ao automóvel. O encantamento e mesmo a impressão de modernidade recaía nos exemplos das estradas em outros contextos e se desejava trazêlas a Santa Catarina.

Havia uma figura chave nessa inspiração e aliança com a elite governante de Santa Catarina com o ex-governante de São Paulo e na epoca, presidente da República. O fato do irmão dois anos mais moço que Adolpho, Vitor Konder (1886-1941) ser o ministro $^{139}$ da Viação e Obras Públicas no Governo Washington Luís. Certamente a centralidade pela temática rodoviária e os constantes elogios às obras de viação do presidente paulista, significavam também a capacidade de mobilizar recursos nessas áreas, para Santa Catarina. Não está apenas na conquista desses fundos territoriais a explicação para os discursos e projetos rodoviários do governo Adolpho Konder, mas também o fato de seu irmão ocupar um posto-chave na esfera federal, o que pode significar liberação de recursos.

De qualquer forma, pode-se perceber uma governamentalidade (FOUCAULT, 1979) das estradas em Santa Catarina, pós-1926, quando nesse ano é criada pelo governo estadual, a Inspetoria de Estradas e Rodagens de Minas, para tornar mais independente - segundo o discurso institucional - e eficiente a reconstrução, conservação e físcalização de estradas. No ano seguinte, 1927, é criada a Caixa de Viação, visando, com ela, à arrecadação de fundos destinados, especificamente, às estradas. Assim, são recolhidos valores, com impostos em: transmissão de propriedade e viação terrestre/trânsito (KONDER, 1928, p.78).

É notável um amálgama do período do governo Adolpho Konder, em que aparecem muito relacionados: a conquista da região identificada com o Sertão; a criação mesmo que inicial de instituições (nacionalização) no Oeste; projetos e planos viários de integração do espaço catarinense por rodovias e; imaginário de bandeirante. Nesses projetos, um dos pontos em comum, mais sólidos, me parece, estava no fortalecimento do poder sobre o espaço de Santa Catarina. Ações lançadas nesses anos 1920 é que possibilitariam, por exemplo, a constituição de bem-sucedidos circuitos de trocas e lucros, projetando aos catarinenses a meta e a identidade de integrarem seu território.

\footnotetext{
139 "Nesse setor de comunicação [Adolpho Konder] contou com o apoio federal, já que, no período, seu irmão Vitor Konder foi o ministro de Viação e Obras Públicas do governo Washington Luis." (MEIRINHO, 1997, p.198).
} 
Faço aqui alguns comentários breves, se trata ainda de considerações elaboradas de maneira inicial a respeito da Viagem de 1929 para após, isso, fazer no próximo capítulo um balanço panorâmico histórico da construção territorial dessa "unidade do país": Santa Catarina. Mencionando a seguinte passagem, que me parece bastante útil a respeito da compreensão da "identificação do Sertão"; dos constituídores dessa identificação (ou os auto-proclamados desbravadores) e por fim do governador como um bandeirante, esses elementos parecem terem ligação na implementação de exercício de territorialidade(s) estatal clássico: "O território exprime a visão geográfica do poder em sua principal manifestação. A espacialização do exercício do poder qualifica um espaço como território. E como bem assinala Michel Foucault, o poder não se define, se exerce." (MORAES, 2005c, p.114). Cabe tão bem interpretar o caso das formas de exercer poderes sobre o espaço, certamente a Viagem de 1929, embora repleta de relatos com imagens de amenidades, de congregação, união e comunhão, ela reflete antes a vontade de um domínio, de poder. Por isso nomear e controlar as toponímias é um dos objetivos importantes para atingir um melhor controle do território.

A autoridade maior representante do executivo estadual, ao recrutar e levar consigo burocratas e funcionários da sua administração ao mais extremo interior de Santa Catarina, teve entre alguns da comitiva que o retravam pelo heró́smo e benevolência do ato de "adentrar" ao Sertão, tal visão de "empreitada" passa a ser resultado da característica como se fosse um administrador estadista, exercendo através de sua posição hierárquica, o símbolo de poder de Santa Catarina em direção ao Oeste. A nomenclatura e aparato que carrega o imaginário Bandeirante lhe serve tão bem no momento de reconhecimento da fronteira, que talvez não haveria outro signo disponível da identidade catarinense a ser mobilizado. Por alguém cujo o pai, era professor e comerciante (Markus Konder 1854-1898), apontam os biógrafos, é nascido em Schweich na Alemanha e imigrou para o Brasil, fixando-se em Itajaí, casando com Adelaide da Silva Flores, tendo o casal oito filhos, entre eles, alguns políticos, como Adolpho e Vitor Konder, (além de Marcos Konder aqui nenhum vez citado) a ideia do Bandeirante nacionalizando o Sertão garantia-lhe um certo distanciamento de sua herança germânica.

Em certa altura, em tom de epopeia - quixotesca - mais que um governante, entre as características apontadas da ação itinerante daquele governo, fora a coragem para enfrentar o desconhecido e realizar o contato com o Outro, e levar-lhes - seja o espaço seja as pessoas - as instituições e as representações de catarinense. Realiza 
nomenclaturas das toponímias. Tais tipos de eventos inaugurais acabam se perpetuando, mais pelas forças de rememorações e repetições de relatos instituidores da origem/gênese do que necessariamente, na comunidades que receberam e acolheram as autoridades. Os textos e as fotografias como os aqui mobilizados, foram escritos, antes por atendentes do poder, possuem intencionalidades para tal uso. Menos para as próprias pessoas da região, a representação da (Viagem) epopéia como um grande feito, responsável pela origem da incorporação do Sertão, são também relatos externos. Tratam-se de memórias que recaem sobre ela, a encobertam e não fazem menos do que a subestimar, legitimando uma imposição cartográfica que acompanha a territorialização do poder que chegou vindo de trem, lancha ou automóvel e acredita lançar racionalidade e nacionalidade na "não civilização".

O Oeste e o extremo-Oeste já existiam antes da passagem do primeiro governador - talvez o que se buscou inaugurar foi o Oeste e extremo-Oeste catarinense - assim como a América portuguesa existia antes da vinda ${ }^{140}$ da família real portuguesa ao Rio de Janeiro em 1808. Entretanto, nas narrativas de culto a origem - como bem criticou François Simiand - tentam fazer crer o quanto ganham os "espaços periféricos" quando por determinadas situações, passam a ser (e a receberem) atenções centrais. Mas tais abordagens, não querem compreender as peculiaridades e valores já presentes, e sim ressaltar a figura da autoridade que chancela o que deve ou não ser, permanecer na e da região e como devem ser chamados os lugares, rios, montanhas... enfim, impor uma cartografia.

Seja representações e capitais (subjetividades ou materialidades), valores são aplicados sobre determinado espaço que a figura do poder (uma autoridade, ou não) deseja ser reconhecido como o mediador a inscrever a região na história. A meta é

\footnotetext{
${ }^{140}$ Talvez aqui, essa tentativa de comparação não seja nada útil, a começar pelo fato de o Governo catarinense não ter sido transferido, nem mesmo as repartições públicas do Estado que mantiveram-se historicamente concentradas na capital, Florianópolis. Sem falar na diferença de quase um século e não mais colônia. Outro impedimento dessa comparação é a complexa diferença da figura do poder real (o Monarca) em relação ao poder do Estado moderno, esse último caracterizado, por exemplo, pelo monopólio da violência dentro de seu território. Mesmo considerando não sendo uma comparação muito fiel, apenas faço essa indicação de que não são as autoridades que por decreto criam as forças dos lugares da noite para o dia, muitas rugosidades se mantém inclusive após atos de "fundações"; afinal, entre a escolhas da América portuguesa, foi na "já estabelecida" Rio de Janeiro que a corte se fixa, gerando uma nova e complexa centralidade: "a transferência da corte portuguesa para a colônia, em 1808, representou um fator essencial no processo de formação histórica do Brasil, notadamente em sua dimensão geopolítica." [...] "A centralidade geográfica instalada não dilui os conflitos inter-regionais, mas atua pesadamente no sentido de unificação territorial da colônia. Unidade que a elevação ao status de reino, em 1815, reforçou." (MORAES, 2009, p.68).
} 
promover-se (pela "coragem de enfrentar" o desconhecido) por tornar o Sertão existente e, superá-lo.

Entretanto, para membros de uma comunidade, de uma vila, das colônias, núcleos urbanos da região, a lembrança da presença de um governador - não o questionamento de tal ato já ter sido ou não, esquecido - parece querer instituir e lembrar os nomes daqueles que ali foram e estiveram de passagem mais do que das comunidades que "receberam a Bandeira". A memória oficial quer registrar menos os que foram visitados e acionados como membros de uma comunidade imaginada, catarinense e/ou brasileira e mais das autoridades e agentes do poder. No olhar de quem estava "lá" no Oeste: são aqueles que chegaram, os litorâneos, os governantes, as autoridades do poder é que eram os Outros.

E a quem interessa se não, aos que exercem o poder, os usos de representação do: Sertão, bandeirante, integração? Acredito que "dinamizar" os fundos territoriais acoplando-os em uma lógica que reproduzisse as histórias das formações sociais das demais regiões de Santa Catarina, torna-se um mecanismo de visualização da territorialização; mas para o governante em 1929 significou mais do que isso, me parece também, ter sido uma estratégia interessante, pois ao mesmo tempo, que ser "de origem" - filho de imigrante - tentar ser reconhecido como um melhor brasileiro (LESSER, 2001), um nativo, Bandeirante. Ou numa narrativa epopéia, o retratará como mais um bravo, "herói territorial". 


\section{CAPÍTULO IV}

\section{TERRITÓRIO FEDERAL DO IGUAÇU (1943-1946)}

\section{Territórios ao Oeste}

Duas boas dissertações de Mestrado trataram do Território do Iguaçu. Uma na Ciência Política da Universidade Estadual de Campinas (IFCH-UNICAM) de autoria de Licério de Oliveira (1999), que estudou o regionalismo fermentado principalmente a partir do Território Federal do Iguaçu e seus resquícios às áreas depois reincorporadas ao Paraná e Santa Catarina. Outra dissertação na História na Universidade Federal Fluminense (UFF) publicada em livro, autoria de Sérgio Lopes (2002), que estudou o Território de Iguaçu no contexto da "Marcha para o Oeste" e as relações de força política entre o Paraná, com representantes no Congresso Nacional e a insignificante representação do Território do Iguaçu na formulação da Constituição de 1946, o que impactou na sua dissolução e retorno das áreas paranaense e catarinense.

Nesse ano de 2015 acaba de sair também um novo livro, escrito por um autor local, professor aposentado no município de Laranjeiras do Sul (PR), antiga sede da capital do território. Trata-se de Arno B. Mussoi (2015), obra Território Federal do Iguaçu, perspectivas para o Desenvolvimento Regional. Para ele, há duas principais vertentes nas concepções dessa temática. Uma corrente a) Paranista; nessa concepção entende o território federal como uma perda (amputada uma parte do Paraná), sendo considerado para autores dessa vertente, mais importante o seu fim e retorno para (re)estabelecimento dos espaços do Paraná (e Santa Catarina). Segundo depoimento em entrevista, Mussoi afirma como nessa visão predomina a ideia "como se a criação do Território do Iguaçu tivesse sido meio a toque de caixa. Meio sem muita importância." (MUSSOI, Depoimento oral, abril 2015, Laranjeiras do Sul-PR).

A segundo corrente, compreende o conjunto maior do País, observando não ter sido apenas a criação de um território federal, mas com ele, outros quatro mais. Nessa perspectiva, poderia ser nomeada, como focando nas b) Políticas varguistas. Tal abordagem, na qual Mussoi se vincula, assim ele explica:

Prioriza a discussão das políticas de Vargas pré a criação do Território Federal do Iguaçu (a linha nacionalista dele) e a marcha para o Oeste e a questão da 
integração do território nacional, principalmente nas regiões praticamente desabitadas. E a gente buscando documentos na imprensa do Paraná, temos aí trabalhos publicados em 1931, como 12 anos antes da criação do território federal já tinha uma comissão para fazer um estudo aqui na região. Desde 1930, da subida de Vargas ao poder, já tinha interesse nessa ideia, 13 anos antes da criação foi feita uma análise. Então, não é assim a toque de caixa como o Wachowicz comenta. (MUSSOI, Depoimento oral, abril 2015, Laranjeiras do Sul-PR).

A partir do desmembramento de áreas de jurisdição de cinco unidades federativas: Amazonas, Pará, Mato Grosso, Paraná e Santa Catarina, no ano 1943, a União criou cinco Territórios Federais: Amapá, Rio Branco, Guaporé, Ponta Porá e Iguaçu. O contexto daquele período caracterizado por conjunto de influencias, entre quais se destaca duas principais: o momento político interno brasileiro com o Estado Novo (1937-1945); a Geopolítica na Segunda Grande Guerra (1939-1945). Outros fatores, como o projeto e discurso institucional da Marcha para o Oeste, a criação de novas unidades da Federação, a busca por melhor controle das fronteiras, assim como a centralidade do discurso geográfico e no caso do Sul, a fronteira com a Argentina, são aspectos que contribuíram na compreensão do momento criação daqueles Territórios Federais.

Imagem 13: Estados existentes (alguns “desmembrados") e os Territórios Federais instituídos em setembro/outubro de 1943 pela Lei n5.812 de 13 de setembro (ver anexo 2)

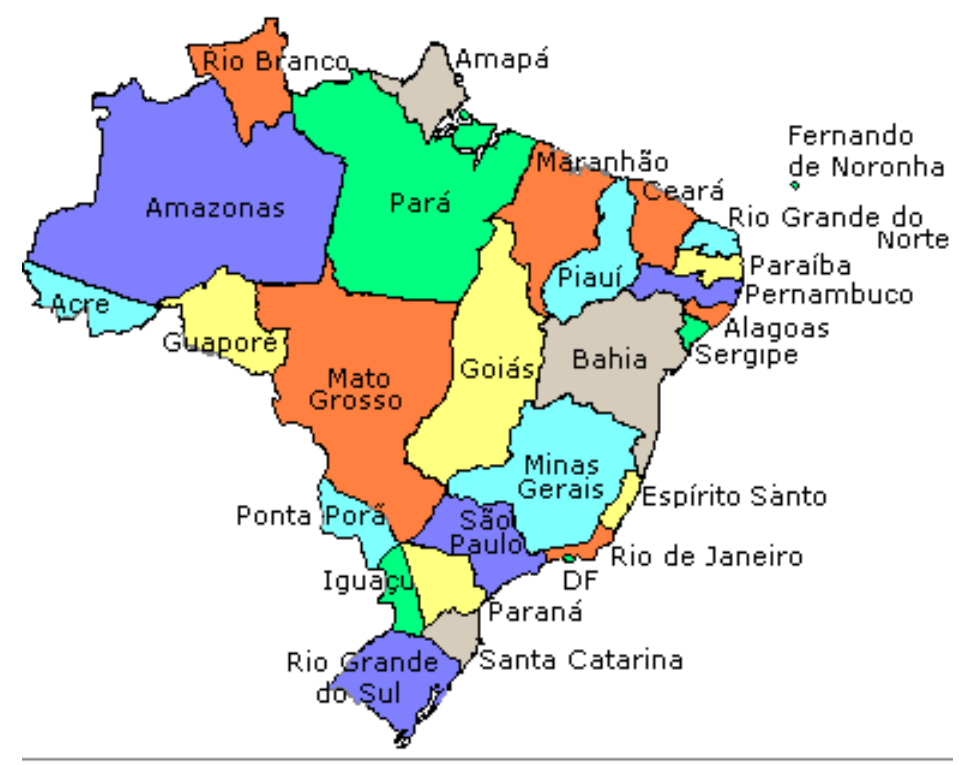

BRASIL - Divisão Político-Administrativa em 1943

Ref. Disponível em:

http://pt.wikipedia.org/wiki/Ficheiro:Brasil divisao politico administrativa 1943.PNG 
Segundo Sérgio Lopes (2002, p.195), dizia-se que antes da criação do espaço dos iguaçuanos, o Paraná possuía aproximadamente 199.897 km² e Santa Catarina $94.998 \mathrm{~km}^{2}$. Após a criação do Território Federal do Iguaçu, descontada a área para criá-lo, ficaram respectivamente, $148.445 \mathrm{~km}^{2}$ área paranaense e $80.596 \mathrm{~km}^{2}$ a área catarinense. Representada anteriormente (na imagem 13), a nova divisão territorial das unidades federativas brasileiras a partir de outubro de 1943.

Acredito que a criação do Território Federal do Iguaçu coloca completamente em cheque - e fortalece a suspeita - em tratar o ano de 1916 com o Acordo dos Limites como o marco da incorporação "definitiva" da construção territorial catarinense, assim também para a Viagem de 1929. Ao menos que não se considere a região Oeste como parte integrante. Penso que à área emancipada como entidade Federal do Território do Iguaçu, expressa as rupturas da invenção da integração de Santa Catarina. Trata-se de um exemplo de um processo que não poderia, necessariamente, resultar na atual cartografia.

Alguns atributos recorrentes na imprensa sobre a criação de Territórios em 1943

a) Militares por serem região de fronteira; contexto da $2^{a}$ Guerra Mundial; importância estratégica para segurança da nação e; para unidade da pátria.

b) Econômicos buscar e promover "progresso" visto como ampliação de contato da erva mate e pinhão com o mercado; tratar do ressurgimento econômico integrando interior na esfera da circulação; aprofundar políticas de colonização em apropriação privada da terra.

Os aspectos militares e econômicos apontados como causas para criação de cinco territórios federais foram condensados ${ }^{141}$ na expressão Marcha para o Oeste.

Quando o segundo governador indicado para assumir a chefia do Território, no governo do presidente Eurico Gaspar Dutra, faz uma representação gráfica do funcionamento da estrutura dos órgãos da administração, é como se a área que pertencia a Santa Catarina, sob jurisdição do Território Federal não tivesse sido catarinense. É como se não reconhecesse o que era o Oeste catarinense, pois, informa ter representantes (do Território) no Rio de Janeiro e em Curitiba, mas não em Florianópolis, ou não em Santa Catarina. O que mais uma fez pode ser ilustrativo da

\footnotetext{
${ }^{141}$ Não deixa de ser também um momento de forte mobilização de discursos associados a temáticas com expressões próximas da Geografia acompanhados de muitas ideologias geográficas. (MORAES, 2005,

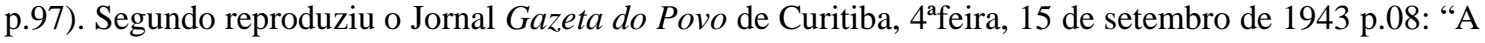
respeito da criação de cinco territórios federais, um vespertino ouviu o senhor Cristovão Leite de Carvalho, presidente do Conselho Nacional de Geografia, o qual disse que o Presidente da República, fez diversos estudos a respeito, tendo traçado as diretrizes do projeto. Acrescentou - que se trata de uma lei que encarando os mais patrióticos objetivos, vem de encontro com os vitais interesses do país e contribuiu de maneira decisiva na efetivação da proclama marcha para o oeste." (destaques meus).
} 
condição de menor peso de influência da capital de Santa Catarina no que corresponderia seu território.

Imagem 14: dos órgãos de apoio do governador não há representante de SC

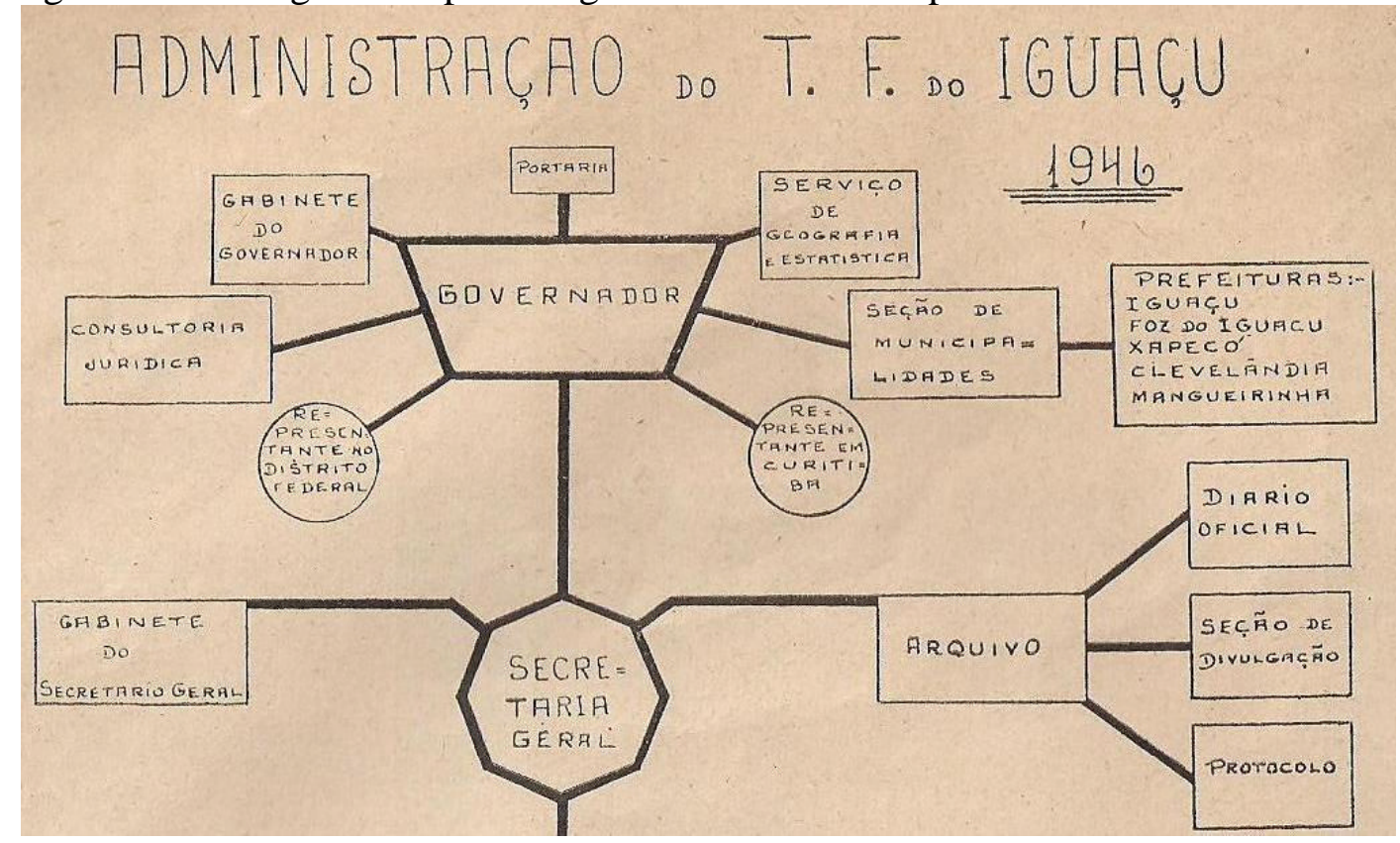

Quando demonstra um organograma das funções e disposição do funcionamento da máquina do Estado do Território, os órgãos da burocracia, chama atenção ao fato do governo ter um representante na capital federal - Rio de Janeiro - e um representante na capital do Paraná, Curitiba. Mas não aparece nem no texto, nem na figura da distribuição das divisões do Estado, nenhuma menção a Santa Catarina ou um representando em Florianópolis. É como se a parte que tivesse sido federalizada; não fosse de (nem tivesse pertencido a) Santa Catarina.

Um jornal de Santa Catarina, quando da criação do Território Federal do Iguaçu, também não se viu nele alguma figura associada às terras catarinense, mas diz ter encontrado sua silhueta o rosto de um ex-presidente dos EUA: 


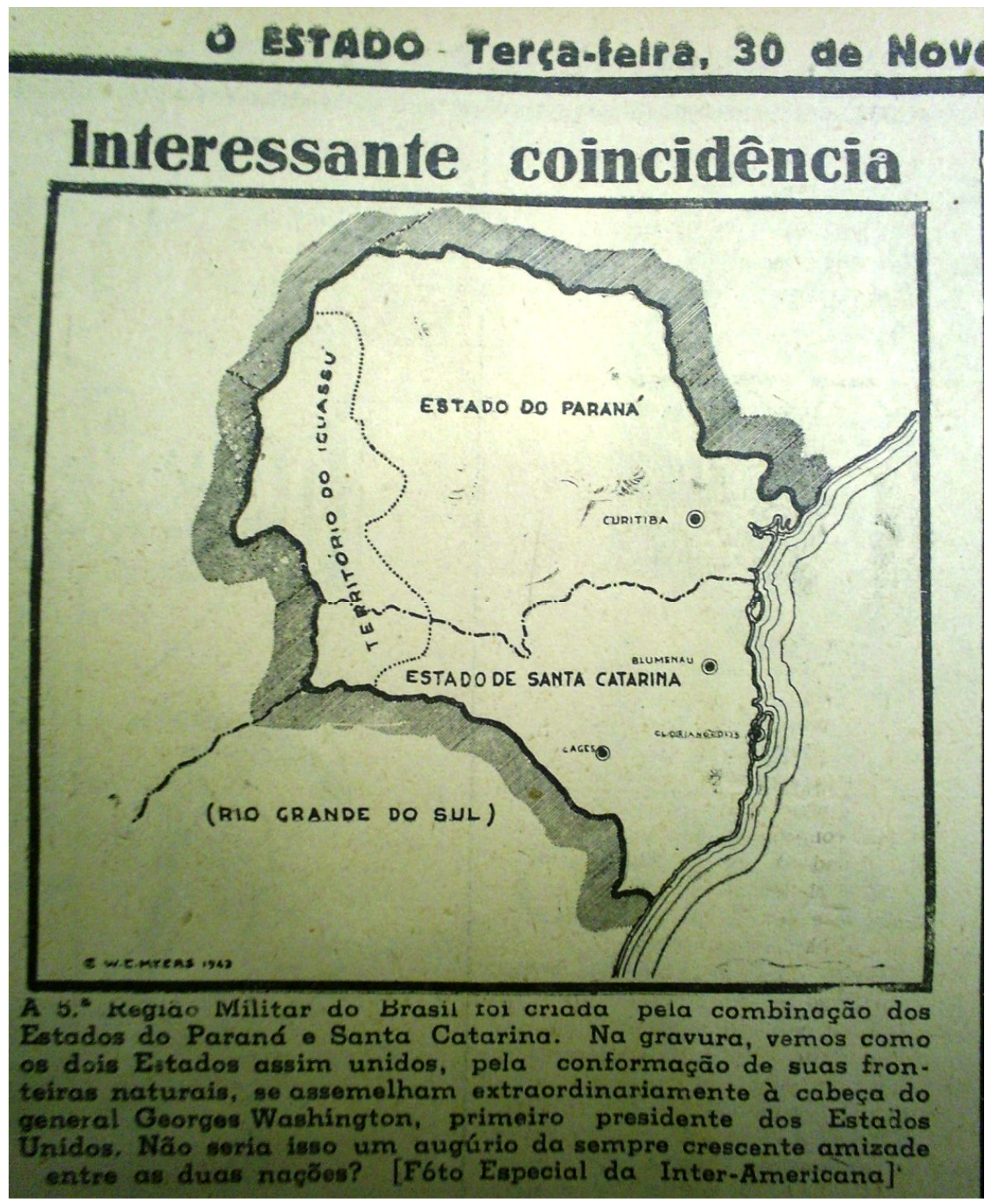

A capacidade de desejar encontrar alguma menção aos EUA, fez um jornal em Santa Catarina dizer ter visto na área correspondente ao Território Federal do Iguaçu a face do primeiro presidente dos EUA. O tal rosto de Washington é relevante e expressivo dessa busca da uma artificial aproximação com EUA. O texto explicativo do encontro de um contorno da "face" ou de uma cabeça do presidente Georges Washington, questiona ao final da aparente coincidência da imagem, se não haveria uma boa e feliz aproximação entre EUA e Brasil? Buscando criar algum vínculo, metáfora, paralelo, "noticiou-se" a novidade do território, uma relação de "proximidade" entre os Países; representa a nova subdivisão de área do Brasil, como se expressando o rosto político estadunidense legitimando-se uma inventada onipresença dos EUA. 
As justificativas que apareceram na imprensa escrita, quando noticiado em páginas de jornais a criação dos territórios federais, quase sempre utilizou da explicações e justificativas militares e/ou econômicas.

Na pesquisa realizada no Arquivo Nacional (do Rio Janeiro), encontrei alguns documentos como correspondências, solicitações e troca de informações entre a administração da capital Federal e as necessidades das autoridades para instalação desse Território. Outros documentos menos comuns, tratam de algumas cartas de pessoas solicitando emprego ou transferência. Também aparecem situações de solicitações de propriedades agrícolas assim como de execução de projetos de colonização.

Imposições: da criação do território e da extinção do mesmo

"E dali para cá, com a entrada do território, nós ficamos muito felizes, até entender o que era território... até compreender, nem sabia o que era. Outros ficaram zangados, tirar um pedaço do Paraná! Depois sofreu de não ter continuado."

Geni Sathler 86 anos, Laranjeiras do Sul (PR), abril 2015

Essa epígrafe acima traduz um pouco do olhar da experiência de quem vivenciou o início e o fim do Território Federal do Iguaçu, tendo lembranças daquele momento. A desconfiança ou desconhecimento inicial, em deixar de pertencer a quem pertencia, nesse caso ao Paraná e, depois, a frustração pela não continuidade, pois, voltaram outra vez às áreas - catarinense e paranaense - a quem respectivamente haviam sido "desmembradas".

A percepção de ter sido "elevado" a um território trouxe consigo ideal de um futuro melhor; tanto das pessoas que pela área habitavam, como por quem se deslocou em busca de oportunidades. Muitas das expectativas geradas em consequencias das instalações construídas, prédios edificados (muitos em madeira) e, principalmente, da elevação de um povoado (Xagú) em uma capital de um território federal, com estabelecimento de governadoria. Uma presença do Estado e proximidades de algumas agências estatais fundadas seja com obras e com oferecimento de serviços públicos foi logo sentida no início, e como resultado do fim do território, o inverso: o abandono. Sentido de projeto abortado, interrompido. Não sendo a população questionada das suas preferências, sem qualquer plebiscito, eleições ou votação para decidir em deixar de ser Paraná e Santa Catarina e após 3 anos, voltar a sê-lo. 
Fiz a menção desse depoimento oral na epígrafe, para também apontar como nem sempre as intenções do Estado são decididas junto com as pessoas envolvidas. Esse caso, sobretudo, sugerido do ponto de vista de alguém que viveu o período da existência de diferentes governanças do espaço, sob gestão federal e mais, ilustra no caso individual, a sobreposição do território na concepção do País, acima das opiniões das comunidades, com tentativa de impor uma invisibilidade da presença de pessoas. Tal como a discussão territorial apresentada por Antonio Carlos R. Moraes, em parte considerável do conjunto de sua obra (como já discutido no Capítulo I). Por outro lado, no caso catarinense, a desanexação dessa área poderia dizer bastante naquele período da não relação desse extremo Oeste com a capital, Florianópolis (tema problematizado no Capítulo I).

O trecho de depoimento usado na epígrafe, colhido com autorização em trabalhos de campo em Laranjeiras do Sul (PR) em abril do ano de 2015, esse município fora a capital do Território Federal do Iguaçu, e quando capital, possuía tal nome oficial, como se observa na imagem a seguir e sua localização:

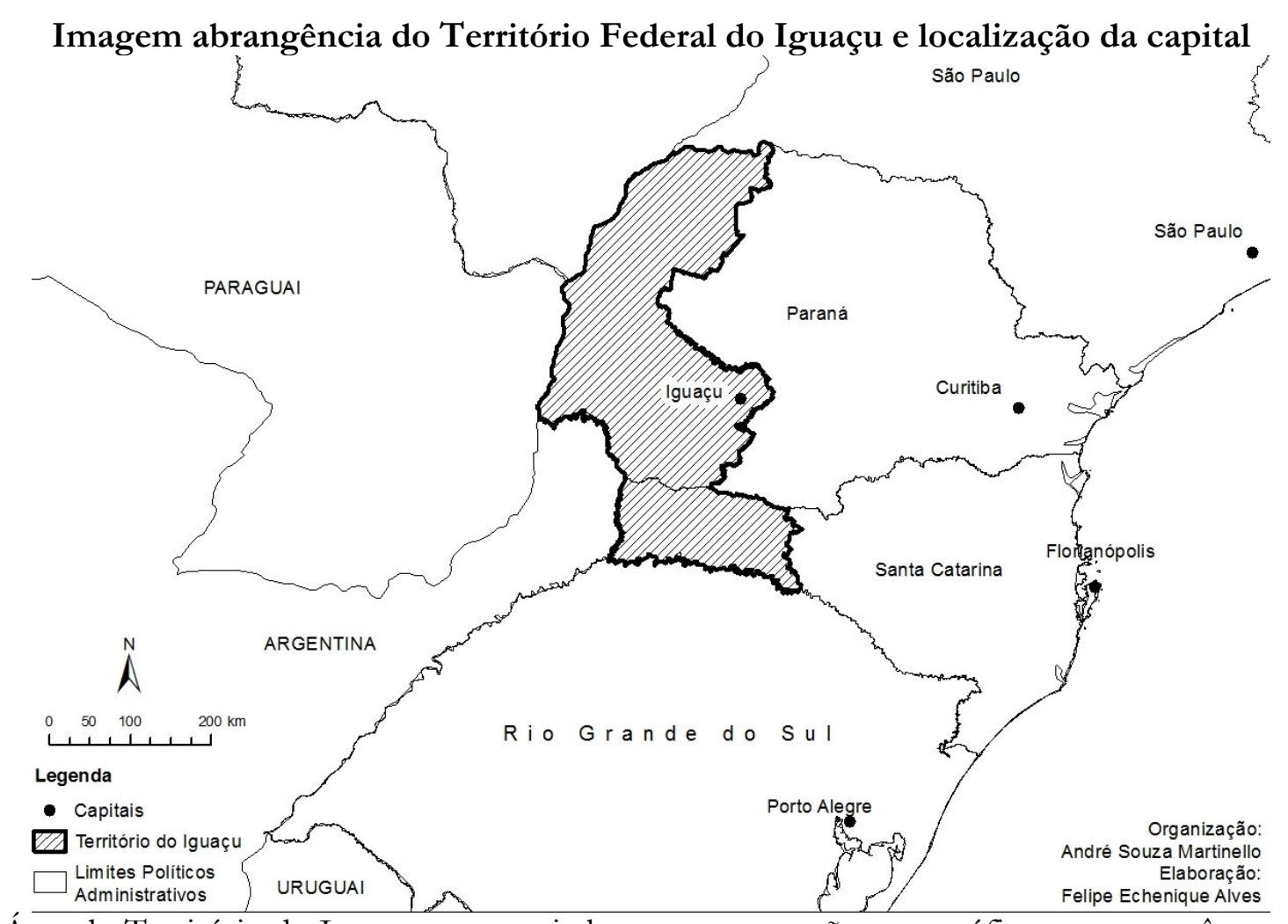

Área do Território do Iguaçu e sua capital, em representação cartográfica contemporânea

A discussão ou ideias sobre a criação de uma unidade do País nas mediações dessa área, já apareciam nas comunicações entre militares, logo em seguida ao resultado 
final do voto de arbitragem do presidente dos EUA, Grover Cleveland em fevereiro de 1895 (como discutido no Capítulo II). Também apareceu mesmo antes, quando se desejava não perder a área em litígio para Argentina, alguns costumavam lembrar o potencial (principalmente naturais) de tornar tal espaço em separado de Santa Catarina e Paraná.

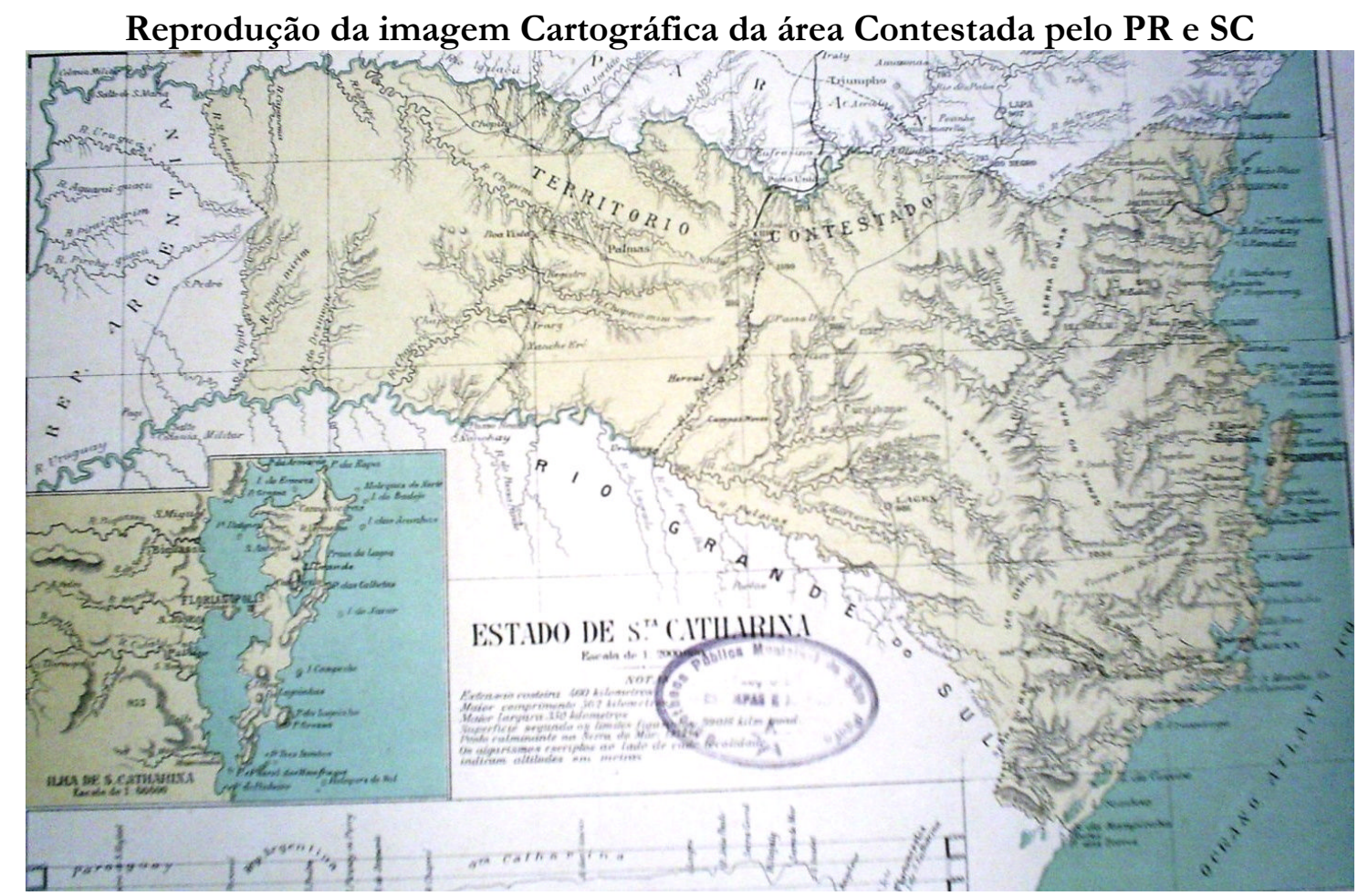

Mapa do acerco cartográfico da Biblioteca Pública Municipal Mário de Andrade de São Paulo.

Antes e durante o período da Guerra no Contestado (1912-1916), (MACHADO, 2004) quando governantes e políticos do Paraná não seguiam as determinações do Supremo Tribunal Federal/STF nas três consultadas realizadas - ou julgamentos dando causa de ganho para Santa Catarina, ficou bastante conhecido o trabalho de Silvio Romero $^{142}$ sugerindo a união dos dois Estado em uma única Unidade Federativa. Para evitar ressentimentos e disputas desse novo Estado que se chamaria, para Romero, Iguaçu, a capital - da proposta de união dos Estados - também deveria ser outra (que não Florianópolis nem Curitiba) e, localizada nas mediações do rio Iguaçu.

\footnotetext{
${ }^{142}$ Segundo algumas pessoas envolvidas no acordo dos dois Estados realizado no Palácio do Catete no Rio de Janeiro em 1916, por volta daquele ano, o Itamarati republicou o texto de Silvio Romero; é ao menos o que afirmou Thiers Fleming (1939, p.07) em artigo publicado na Revista da Sociedade de Geografia do Rio de Janeiro: (destaques meus) '[...] intensifica-se o 'zum-zum' de que o 'acordo' não será assinado; notícias, de fonte catarinense, em certos jornais, pretendem quebrar a bela e patriótica unidade de vistas da imprensa carioca a favor do acordo. Fala-se de novo no Estado de 'Iguassú' formado pela união dos Estados de Santa Catarina e Paraná e o projeto de Sílvio Romero é reeditado pelo Itamaratí."
} 
E a capital?... Há de ser essa encantadora povoação a margem do belo Iguaçu, sobre o território que cada um dos Estados considera seu, a setecentos metros acima do mar, e que tem o nome sugestivo de Porto União. Chamam-na ainda de União da Vitória. Os lugares têm também seus destinos... De União e Vitória vai ser a bela cidade que se há de edificar ali para a capital do poderoso, vasto e riquíssimo Estado do... Iguaçu ou do Guairá. (ROMERO, 1916, p.20).

O curioso não é si, apenas, a proposta de Silvio Romero de juntar Santa Catarina e o Paraná em único Estado. Mas é muito relevante como 30 anos depois, a mesma ideia é retomada pelo último e ex-governador do Território Federal, quando já extinto o mesmo, Frederico Trotta afirma estar divulgando essa sugestão. Da junção desses dois Estados, sairia maior força política, maior capacidade de competição com outras unidades federativas do País, “[...] fazendo equilíbrio com São Paulo, Minas, Rio Grande e Bahia." (TROTTA, 1947, p.120).

Consolidando uma contribuição da grandeza territorial do Brasil, a opinião do ex-governador também parecido embalada pelo ressentimento do fim desse território:

Já que não pode ser mantido o Território Federal do Iguaçu - seria interessante que os dois Estados do Paraná e Santa Catarina se fundissem num só com a capital sediada em Porto União e União da Vitória - ligação natural entre as duas unidades federativas e entre as zonas servidas de estradas de ferro e os sertões do oeste. As possibilidades desse novo grande Estado no ponto de vista econômico, administrativo e político seriam maiores do que a soma das duas parcelas quando consideradas separadamente [...]. A economia resultante da fusão das duas administrações [...] criar-se-ia uma unidade de doutrina que muito iria beneficiar todas as regiões, mormente com o afastamento da capital da orla litorânea, pois é ponto pacifico que Curitiba e Florianópolis estão mal situadas como capitais. (TROTTA, 1947, p.120).

Com o fim do Território do Iguaçu, as áreas que haviam sido desmembradas, retornaram a mesma divisão do Acordo celebrado no Palácio do Catete em 1916, com mediação do Presidente da República, dividindo o espaço entre os Estados que contestavam como sua a área, ficando aproximadamente $20.000 \mathrm{Km}^{2}$ ao Paraná e aproximadamente $27.000 \mathrm{~km}^{2}$ para Santa Catarina. A imagem anterior demonstra como a produção cartográfica, considerava nas suas representações do espaço, as dúvidas sobre a quem pertencia.

Fora recorrente ideias (como as discutidas no próximo item), a respeito dessa área - a que passou a cobrir o Território Federal - tornar-se independente do Paraná e Santa Catarina. Uma década antes da implantação do Território Federal do Iguaçu, houve uma difundida proposição dessa sugestão, como apareceu em algumas 
publicações de uma revista que editava discussões envolvendo Geografia, em uma sociedade com sede na capital federal, na época, Rio de Janeiro.

\section{Sociedade de Geografia do Rio de Janeiro/SGRJ e a redivisão territorial do País}

Quando se verifica a produção intelectual e propostas de análises territoriais do Brasil, em décadas antes da institucionalização formal da disciplina acadêmica Geografia, na(s) Universidade(s) brasileira(s), não significa ser correta a associação direta da "não formação" de quadros, com a não existência de pensamentos de cunho geográfico. Tem se consolidado diferentes pesquisas e questionamentos, apontando uma relativa grande quantidade de debates, projetos, "propostas de soluções" de problemas, pelo viés - o que se poderia considerar como sendo - da Geografia produzida antes da criação dessa disciplina no Brasil. ${ }^{143}$ Essa foi, por exemplo, uma entre as grandes preocupações de investigações de Antonio Carlos R. Moraes (1991): entender a separação temporal do pensamento geográfico brasileiro; da posterior reflexão acadêmica geográfica e o(s) por quê(s) da emergência discursiva tão antes da disciplina (e demorada institucionalização da comunidade de geógrafos/as).

Muitas vezes, talvez na maior parte delas, um aparente "debate" foi reducionista, não só simplificando ideias (de escolas geográficas nacionais) trazidas do exterior, particularmente da Europa, mas legitimando variadas perspectivas conservadoras, autoritárias e até racistas, com sustentação de "aporte" em considerados então, renomados geógrafos. Chancelava-se um eurocentrismo nada discreto, mesmo nas propostas dizendo serem as mais nacionalistas, ou pela admiração e desejo do nacionalismo, embarcou-se em etnocentrismo vulgar, encontrando guarida na Geografia européia. Desembocou-se em conjunto de interpretações generalizantes e rasteiras, analisadas por Antonio Carlos R. Moraes (2005b) em Ideologias geográficas.

Embora algumas simplificações tenham dominado as discussões, alguns argumentos (mesmo que não concordemos com eles) foram bem elaboradas; nem todos usavam de interpretações mecanicista prontas. Quando se analisa parte dos debates antes da constituição da disciplina Geografia no Brasil, não é suficiente tentar criticá-los como se discursos incompetentes; mas entendê-los seus limites e contribuições, dentro de uma lógica do período. Talvez até possamos vê-los - algumas das discussões - como

\footnotetext{
${ }^{143}$ Ver a respeito, por exemplo: Luciene P. Carris Cardoso (2013) O lugar da Geografia brasileira; Manoel F. Sousa Neto (2004) Planos para o Império; Lia O. Machado (1995) Origens do pensamento geográfico no Brasil; Sergio L. N. Pereira (1997) Geografias, caminhos e lugares da produção do saber geográfico no Brasil; Fabio B. Contel (2014) As divisões regionais do IBGE no séc.XX; Antonio Carlos R. Moraes (2005) Ideologias geográficas.
} 
não "menos importantes", nem inferiores ao que fazem geógrafos na atualidade: crítica válida a alguns ramos e posicionamentos de geógrafos atuais? Projetos a respeito do território brasileiro e ordenamento territorial do País não foram só rasos; existindo não apenas os voluntaristas "bem intencionados".

Talvez, influenciados e redigidos por membros (ou sujeitos socializados em uma) em mais altas esferas das instituições que mais recebiam recursos do Estado, as forças armadas. Com certo grau de instrução e formação complexa, não disponível nem tão rotineiramente existente nas esferas das formações de profissões civis, me refiro principalmente a Marinha, mas também ao Exército, pode ajudar a interpretação da existência de textos bastante explicativos e repletos de informações e propostas de intervenção planejadas. Além, muitas vezes, da própria origem social dos sujeitos. ${ }^{144}$

Seria muito simplificador, tratar intelectualidade do passado como menos capaz e envolvidas em tramas, enlaces e enredadas em paixões, como se, apenas no presente, tivéssemos capacidade de não nos envolvermos em embates políticos com interesses claros. Ou como se, apenas hoje, conseguimos saudável distância do que "eles" não faziam questão de propor a ter. Pode parecer caricatural, ou tentativa de resgatar projetos do século passado para olhar o presente, não se trata disso. Como exemplo, uma breve análise de um documento publicado no ano de 1933 pela Revista da Sociedade de Geografia do Rio de Janeiro/SGRJ, tratando a respeito da proposta de refazer a divisão territorial do Brasil.

Gostaria de chamar atenção para o fato, de no mínimo uma década antes do presidente Getúlio Vargas ter instituído cinco territórios federais em 1943 (quais sejam: Amapá, Rio Branco, Guaporé, Ponta Porã e Iguaçu), anteriormente, ter sido recorrente discussões a respeito das espacialidades dos níveis dos poderes do Estado brasileiro. $\mathrm{O}$ caso de uma Redação final da matéria vencedora, "selecionada" para sair impressa na Revista da SGRJ é bastante ilustrativo, da complexidade de temas propostos nos discursos realizados há mais de 8 décadas atrás. Mesmo não deixando de ser um ideologia geográfica, é um documento que porta racionalidade, em linguagem

\footnotetext{
${ }^{144}$ Existiam discussões e elaborações geográficas em outras esferas e instâncias do Estado; antes de criação do Conselho Brasileiro de Geografia (em março de 1937), por exemplo, o Ministério da Agricultura também fazia levantamentos que mais tarde foram alojados no Instituto Brasileiro de Geografia e Estatística/IBGE. Como lembra Fabio B. Contel (2014, p.03): ""O estudo da configuração natural do território já era realizado de forma pulverizada por órgãos do Governo Federal e autarquias estaduais, principalmente aquelas ligadas à produção agrícola." Sobre origem social de indivíduos e a produção de saber geográfico, ver o caso, em Lincoln F. Secco (2008) Caio Prado Júnior o sentido da revolução.
} 
sofisticada, com argumentos claros e propositivos. Mas, certamente, guarda distância de participação popular tanto no que se refere à elaboração do projeto como na execução.

O texto assinado ao final como se em autoria coletiva, é menos assinatura de indivíduos comuns (cidadãos da sociedade civil não aparecem), mas de representantes de instituições. Várias autoridades representantes de "grupos" diferentes, todos homens, parecem buscar legitimidade de poder, para creditar veracidade das análises e sugestões. São das instituições que representam e seguem após os seus nomes ${ }^{145}$ como se chancelando peso de autoridade ao documento. Apenas, afirma no início do dossiê, ter sido redigido no contexto do debate proposto e realizado pela instituição SGRJ, responsável também pela criação de "uma grande comissão nacional de redivisão territorial e localização da capital."

Como afirmou em recente livro - no qual a autora trata da SGRJ - de Luciene P. C. Cardoso (2013, p.144), entre os anos de 1930 e 1945, o Estado brasileiro exprimiu com vigor, uma cultura geográfica de raiz nacionalista. Mais do que apenas nacionalista, poderia associar diretamente a uma dupla raiz, com influência de cultura geográfica militar, pois parte da Geografia foi feita, inclusive, pelos próprios agentes das forças armadas. Muitos discursos elaborados no âmbito da SGRJ fora uma das expressões mais influentes durante o governo desse período. Diziam chamar para si, por exemplo, a "responsabilidade" e tarefa do processo de nacionalização. Alguns membros da SGRJ, ou autores dos artigos publicados nas páginas da revista dessa sociedade geográfica, escreviam afirmar estarem dispostos a propor o combate ao que consideravam ser um forte regionalismo brasileiro; culpado por ser dispersivo e fragmentador da nação. ${ }^{146}$

\footnotetext{
${ }^{145}$ Menciono a seguir os nomes segundo a ordem na qual saíram publicados (com data de 18 de outubro de 1933), não para apontar quem eram, mas como antes do nome havia o grau de hierarquia da "autoridade" e após o nome de registro civil, o cargo ocupada na instituição mencionada, usada para ampliar o peso de autoridade. "(Assinados): Everardo Backheuser, presidente da Sociedade de Geografia [SGRJ].; Hélio Gomes, relator da Sociedade dos Amigos de Alberto Torres.; José Lessa Bastos, $2^{\text {a }}$ Secretário, pelo Clube Militar; Raymundo Pereira da Silva, Pelo Clube de Engenharia.; H. Canabarro Reichardt, Pelo Instituto dos Advogados.; Tte. Coronel Raul Bandeira de Mello, Pelo Instituto de Engenharia Militar.; General Liberato Bittencourt e Capitão Edmundo Gastão da Cunha, Pelo Serviço Geográfico do Exército; Major Antonio Alves Fernandes Távora - Pela Sociedade dos Amigos de Alberto Torres.; José Pedro Carneiro da Cunha, Alcides Bezerra e Saladino de Gusmão, Pela Sociedade de Geografia do Rio de Janeiro.; Cap. de Corveta Antonio Alves da Camara e Capitão Tenente Ary dos Santos Rangel, Pelo Ministério da Marinha.; Major Raul Silveira de Mello e Major Mario Ramos, Pelo Estado Maior do Exército.” (SGRJ, 2ºm.; 1933, p. 140-141).

${ }^{146}$ Concepção política que influenciou de maneira a hegemonizar toda uma época no sentido de construção nacional sufocada pela força do regional, mesmo que também tenha sido, embora parecendo contraditório, durante o primeiro governo do Vargas a realização da primeira regionalização oficial brasileira, visando contribuir ao Estado e feito pelo próprio: "A primeira divisão regional oficial do Brasil
} 
Essa versão não terá ruptura tão rápida, permanecendo tanto na criação do Território Federal do Iguaçu, como no lamento quando da sua extinção. Como fez, por exemplo, o último governador para quem "O que é bom em São Paulo ou Goiás, poderá produzir resultados sofríveis, nulos, ou mesmo prejudiciais em Clevelândia, Iguaçu, etc.” (TROTTA, 1947, p.08). Segundo Major Trotta: “O regionalismo deve ser posto à margem quando não trouxer no seu bojo o real beneficio do torrão natal. Para os brasileiros o Brasil deve ser em todo único." (TROTTA, 1947, p.120).

Com perfil de propostas como àquelas de combate ao regional, colocava-se como uma das metas da SGRJ, contribuir na busca por atingir harmonia do todo, removendo desequilíbrios entre "as partes". A concepção dessa Sociedade de Geografia do Rio de Janeiro, que à partir de 1945 torna-se a Sociedade de Geografia Brasileira, porta um discurso muito semelhante, ao que os governantes dos Territórios Federais farão na década seguinte a esse relatório do começo dos anos 1930.

Em contraposição a um alegado "sentimento marcadamente regionalista", a Sociedade [SGRJ] decidiu formar um grupo de trabalho com a finalidade de estudar um novo desenho político-administrativo para [sic] o país. Denominado de "Grande Comissão Nacional de Redivisão Territorial e Localização da Capital Federal", o grupo seria coordenado por Everardo Backheuser, então vice-presidente da Sociedade de Geografia, e deveria somar [variados] esforços [...] (CARDOSO, 2013, p.145).

Para ocorrer um requilíbrio entre regiões e assim atingir um Estado de nação plena, propuseram uma nova disposição das divisões internas dos espaços do País e a reflexão de como a proposta de harmonização se daria. A elaboração do dossiê a respeito da proposta da nova configuração seria feito por uma comissão. É o relatório dessa comissão que é publicado na revista SGRJ e nele aparece em 1933, como um dos territórios federais, o de Iguaçu. Portanto, nesse contexto, entre os principais objetivos para criação de territórios estaria na busca por atingir maior grau de nacionalidade. Em 1947, no último relatório de governador do Território Federal ao presidente da República, assim, por exemplo, mencionou Major Trotta:

[...] os municípios componentes do Território Federal do Iguaçu eram pedaços sagrados da nossa Pátria e portanto tudo que fizéssemos de bom, de aproveitável, o seria em proveito dos Estados para os quais retornariam, trazendo como resultado final benefícios a toda a Federação, por isso que quanto mais ricos e mais bem aparelhados

foi realizada pelo IBGE no final da década de 1930, e se institucionalizou a partir da Circular No. 1 de 31 de janeiro de 1942 da Secretaria da Presidência da República. O principal articulador e teórico da divisão foi Fabio Macedo Soares Guimarães, então Chefe da Divisão de Geografia do Conselho Nacional de Geografia do IBGE." (CONTEL, 2014, p.03) 
estivessem suas unidades, mais rico e aparelhados estará o Brasil. (TROTTA, 1947, p.08)

O diagnóstico presente no início daquele documento da SGRJ estava em completa sintonia com os discursos influentes e constantes entre as justificativas da ascensão de Getúlio Vargas ao poder, assim como serão também a dos governadores indicados para assumirem as governanças dos Territórios Federais, quase todos não civis e sim, militares. Quero chamar atenção para àquela principal ideia de haver uma forte concentração de representação política, para uma ou outra unidade federativa.

Constatavam: os Estados grandes, "com vastos recursos de natureza diversa", dominam "toda a administração federal revezando-se no poder, dele se aproveitando para mais se enriquecerem com o precioso auxilio das rendas federais que drenam para os seus territórios." (SGRJ, $2^{\circ}$ semestre, 1933, p.127). Esse tipo de interpretação certamente interessava ao poder exercido por Vargas e quem o acompanhava, ainda mais pós a polêmica disputa constitucionalista de 1932.

Houve mobilizações de discursos da unidade nacional, para legitimar a mudança política de 1930, principalmente aqueles que pregaram necessidade de interromper a não alternância ou excessiva continuidade administrativa, crítica indireta a (alcunha) República Café com Leite. Certamente, a percepção de acúmulo de representantes do poder concentracionista, era direcionada sobretudo à São Paulo. "No fundo, buscava-se diminuir o poder das unidades mais expressivas da Federação, a propósito de promover o equilíbrio entre os estados." (CARDOSO, 2013, p145).

Mas o que eu gostaria mais de chamar atenção como uma das minhas principais conclusões dessa pesquisa, está no fato da ideia consolidada nos anos das décadas de 1930 e 1940 de ter que haver e mesmo impor a força da União, devendo-se diminuir o regional e evitar o "sobrepeso" político superconcentrado em São Paulo. Por outro lado, não parecia nada contraditório a tais discursos e concepções, apelar, mobilizar ou se utilizar de representações, imaginários ou concepções dos paulistas na representação de um tipo de brasilidade; qual seja: a do dever de expansão, de seguir, adentrar e conquistar os sertões. O último governador do Território Federal vai dizer que é necessário dar estímulos para as pessoas irem viver e colonizarem tais áreas, assim como havia estímulos econômicos num imaginário da época das Bandeiras: "A epopéia dos bandeirantes só foi possível porque havia a acenar-lhes, no ocidente, possibilidades de riquezas." (TROTTA, 1947, p.12). 
Ao mesmo tempo em que se parecia como um dos principais pilares e contexto (do pano de fundo) das propostas dos Vargas um certo tipo de embate ou combate à São Paulo e particularmente aos governos da primeira República, por outro lado, a parte bastante influente da identidade nacional proposta, da ideia de Marcha para o Oeste, de desbravamento dos sertões era também uma associação direta à bandeira paulista, ou ao regionalismo paulista. Quero defender, portanto, como tenso sido um momento bastante ambivalente e como requer o apelo nacionalista segundo Benedict Anderson, não significa coerência, mas sim, envolvido mais em apelos emocionais, do que propriamente, coerentes como racionalidade.

Vejamos em relação ao caso do Território Federal do Iguaçu. Em muitas passagens do último relatório enviado pelo (ex-)governador Trotta, a ideia de levar, construir ou fazer acontecer o Brasil e a brasilidade por meio dos novos Territórios Federais, mobilizava uma metáfora de sertão e às pessoas que iam até os sertões, eram verdadeiros bandeirantes: "[...] um grupo de abnegadas professoras, que como bandeirantes deixaram o conforto de seus lares, o convívio de uma grande cidade, para em pleno sertão, sem recursos, se dedicarem com entusiasmo exclusivamente ao ensino [...].” (Relatório, 1947, p.68).

Não quero aqui negar a presença da conjuntura política que ajuda a embalar o diagnóstico da SGRJ no período em que o mesmo é publicado. Interessa usá-lo apontando como consequência e exemplo das paixões das circunstâncias, apresentando propostas de discussão territorial brasileira. Alguém poderia muito bem tratar com esse mesmo documento, uma rejeição de concepção que, de antemão, previsse como hipótese, a vulgarização simplória de discussões em época pré-universitária da abordagem de Geografia do Brasil. Não é possível reduzir as análises e sugestões de alguns desses textos como se não maduras ou resultado de uma proto-geografia. ${ }^{147}$

\footnotetext{
${ }^{147}$ Tanto no século XIX, como no séc. XX e antes da ascensão do governo Vargas, já haviam elaborações desejando alcançar uma política planificadora e territorial para o Brasil, quase sempre que desembocasse em mais integração e consequentemente, maior harmonia e coesão. Ver, por exemplo, tese de doutoramento em Geografia Humana de Manoel F. Sousa Neto (2004) "Planos para o Império, os planos de viação do segundo reinado." Os projetos de divisões regionais para o Brasil aparecem mesmo antes da consolidação do Estado nacional, alguns feitos até por estrangeiros, como pontua Fábio B. Contel (2014, p.03): “Antes da primeira divisão regional oficial criada pelo IBGE em 1942, algumas propostas tiveram significativa projeção nos meios intelectuais e mesmo em órgãos da administração pública. Segundo Ignes Teixeira Guerra (1968, p.61), dentre as mais importantes divisões regionais do Brasil que fizeram parte dos debates que antecedem a divisão do IBGE, destacam-se as seguintes: a de André Rebouças (1889), dividindo o país em "10 áreas agrícolas"; Elisée Reclus (1893), dividindo o país em 8 regiões; Said Ali (1905), propondo 5 regiões para o Brasil; Delgado de Carvalho (1913), cuja proposta serviu de base para a primeira divisão oficial (por sua influência em Fabio de Macedo Soares Guimarães); Pierre
} 
Embora, autores desses diagnósticos tivessem eles mesmos, interesses em indicar e ocupar postos criados à partir de novas esferas da administração estatal. Havia intenções não necessariamente postas, nem mencionadas no dossiê; com intencionalidades submersas ao território.

Parto do documento proposto a redivisão territorial do Brasil publicado na Revista da SGRJ para buscar apontar dois aspectos: 1) existência da discussão sobre (re)ordenamento territorial muito antes da criação das cinco áreas colocadas sob administração direta da União em 1943 e, principalmente; 2) compreender ter havido discursos propositivos e polidos - como quisermos adjetivar ou denominar - usando de discussão territorial do Estado brasileiro, para promover mais espaços de poder, governança, cargos e atuação para o que talvez pudéssemos denominar, vulgarmente, de intelectuais orgânicos do território. Não estranha serem membros das forças armadas (ou pensamentos vinculados à militarização política do contexto) a dar amplo apoio à ascensão de Vargas ao poder; e também, serem esses grupos um dos principais a promoverem sugestões das administrações de "espaços do País" criados sob guardachuva varguista. Na prática, foram os primeiros a ocupar os cargo e postos de comando, quando criadas as instâncias (ou entes) dos territoriais federais.

Não estou convicto que era o Estado quem tutelava esses territórios, mas dentro do Estado, àqueles com mais forças de pressão - as armadas - destaque para os militares. Segundo a opinião dos que assinaram o dossiê da Comissão da Redivisão Territorial, durante a elaboração da Primeira Constituição republicana brasileira, de 1891, houve quem pretendesse ordenar o território do Brasil em comarcas, tendo como inspiração - na semelhança - dos departamentos franceses. Entretanto, não houve profundas alterações, pois, manteve-se as subdivisões advindas do Império. As mesmas Províncias passaram a ser Estados (partes da União), saindo vencedor um espírito particularista "mais poderoso do que o sentimento da nacionalidade." (SGRJ, $2^{\circ}$ sem., 1933, p.128). O movimento de 1930, busca contrapor-se essa concepção tratada como fragmentária do Brasil.

No caso brasileiro, genericamente, o mais curioso e complexo está na forte tentativa de convencimento que parte importante das forças armadas desejam passar: de servirem não apenas para resguardar o território do País, mas protetores do nacionalismo. Como se, diria Antonio Carlos R. Moraes, salvaguardando o território 
bastaria e seria o suficiente para resguardar o que há de mais nacional. Salvacionistas das pessoas, inclusive delas mesmas e do "perigo das maiorias" ou as multidões; quando fora recorrente, por exemplo, na última ditadura militar, afirmativas como da necessidade de intervenção, pois brasileiros não sabiam votar. Cabendo então, às forças armadas, proteger os bons eleitores brasileiros, até quando àqueles ("maus eleitores") que não soubessem exprimir seus votos nas urnas, passassem a fazê-lo. Suprimiu-se votos de ambos, "bons" e "maus", as forças, responsáveis, em tese, apenas, no resguardo do território pelo monopólio da violência, é quem pretensamente saberiam colocar o interesse da nação acima dos interesses "menores."

A expressão semiótica da imagem a seguir, também dá um tom bastante ligado ao militar aos territórios criados, ao ser dado voz aos membros das forças armadas para explicarem o que se tratava essas novidades criadas, como noticiou na imprensa:

Territórios Federais instalados em 1943 tem uma relação direta com forças armadas

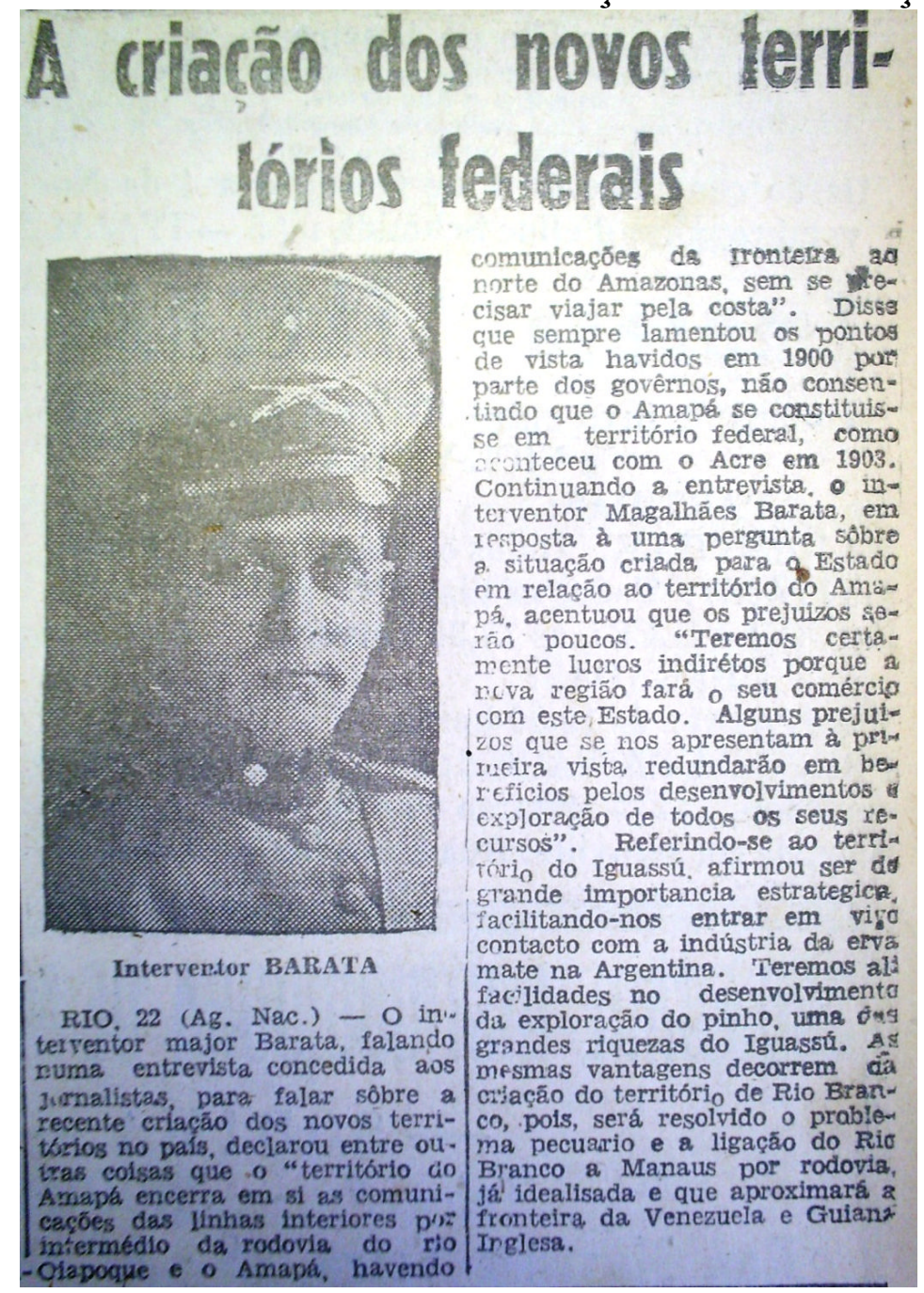

Criação de territórios federais 
O objetivo da elaboração do diagnóstico de 1933, dizia se propor a defender a ampliação e consolidação da unidade nacional. Para esse texto, uma boa divisão territorial estaria subordinada a fortalecer os laços da união nacional. Claramente, a ideologia geográfica - reafirmando a constatação de Antonio Carlos R. Moraes - triunfa no discurso do período varguista. Os países de inspiração continuavam sendo, como já tratado no Capitulo II, principalmente os Estados Unidos e a França. ${ }^{148}$ Mas, claramente, uma inspiração mediada, pois silenciando os direitos dos cidadãos e mais ainda, o voto livre em representantes, caracterizando a democracia representativa de parte da Europa e da América do Norte. O dossiê publicado nas páginas da revista do SGRJ faz referência não aos aspectos da(s) sociedade(s) e suas características formadora dessas nações, mas o que parecia ser entendido como bem elaboradas gestões territoriais; posto verem nesses Países como tendo centralização sem escancarados desequilíbrios.

A desigualdade social não aparece em nenhum momento do texto, como se os espaços fossem apenas desiguais por natureza ou por atributos de valor não humano. A ideia era apresentar a defesa de uma centralização brasileira, meta de Vargas, mas como resultado de (re)equilíbrios por nivelamentos das regiões. Aqui entra as propostas de novas divisões internas brasileiras. As desigualdades são das regiões, mas internamente a elas não se pauta outras desigualdades, como as de classe social, por exemplo.

Para os projetistas da necessidade de uma nova divisão das unidades federativas brasileira, haveria que harmonizar o território das conformidade do País, com propostas claras de evitar concentração, realizando para tanto, fragmentações das áreas já existentes, com estabelecimento de alguns critérios para tais divisões. Quanto maior população, menor a área total do espaço de uma unidade federativa: não poderia deixar juntas uma grande quantidade de superfície com grande quantidade populacional. Propunha-se também, estabelecer um tamanho máximo do território para as unidades federadas e valendo também para tanto, o critério de preço do solo; quanto mais dispêndio de capital por área, menor seria o tamanho total dessa unidade do País: "Onde as terras forem mais valorizadas, aí ela será menor.” (SGRJ, 2ºm., 1933, p.130).

Ainda segundo esse dossiê da Redação final da matéria vencedora (sobre a comissão nacional de redivisão territorial), as normatizações das áreas correspondentes

\footnotetext{
148 "Os países em que as províncias, nas suas várias zonas geográficas, equivalem-se em força política, como a França e os Estados Unidos, obtêm mais sólido equilíbrio político e mais estável coesão.” (SGRJ, $2^{\circ}$ sem., 1933, p.130).
} 
às administrações abaixo do poder central - das unidades federativas, portanto - não devem ser congeladas, mas tendo disposições de alterações dos critérios ao longo do tempo. A nova divisão do País proposta, ou seus critérios para tanto, não era definitiva nem “imóvel, rígida, antes se adaptará às condições novas que surgirem” (SGRJ, $2^{\circ}$ sem., 1933, p.130). As dinâmicas populacionais e das migrações, por exemplo, poderiam gerar novos desequilíbrios e concentrações em áreas, devendo, em consequência, desencadear novos rearranjos das divisões, tendo como um dos critérios: a atração e efetivo crescimento demográfico e/ou superpopulação. A proposta de repartir Estados do País buscou equivaler: superfície, população e eficiência econômica (CARDOSO, 2013, p.146).

A própria nomenclatura das unidades deveria ser alterada, segundo essa proposta. Mais uma vez é possível observar o auto grau de influência de uma acepção varguista do território presente nesse dossiê, quando defendem o retorno do uso da expressão das unidades brasileiras presentes durante o Império. “A expressão Estado lembra a ideia de soberania, que pertence unicamente à Nação; a designação Província, além de restabelecer nossa tradição histórica, está mais de acordo com o sentido de autonomia política, que lhe cabe.” (SGRJ, $2^{\circ}$ sem., 1933, p.131).

O novo mapa das unidades internas do Brasil seria diferente, e entre essas subdivisões apresentadas em 1933 na revista da SGRJ, estava ao que dez anos depois, seria correspondente ao Território Federal do Iguaçu. Diferente do realizado em 1943, com cinco territórios instituídos por decreto, o plano publicado pela SGRJ apresenta proposta de 10 territórios como na imagem a seguir:

Proposta em 1933 de criação de 10 novos territórios federais, segundo comissão da SGRJ 


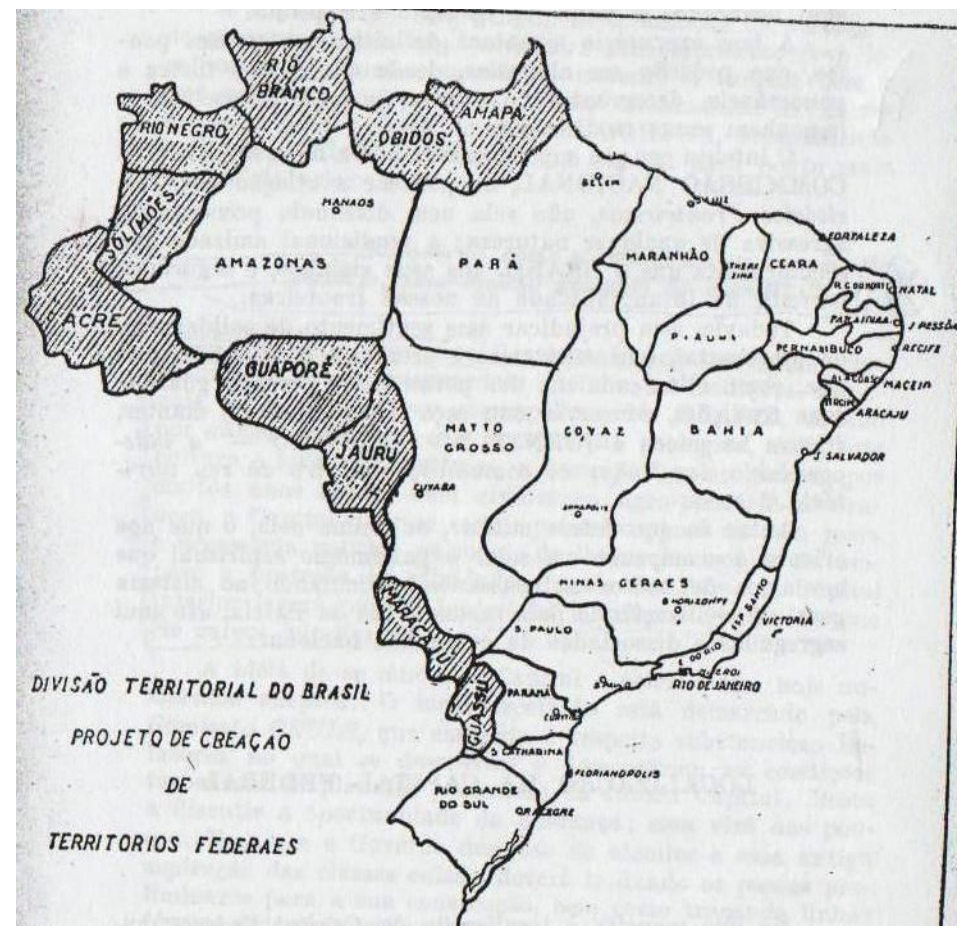

Imagem, Fonte: Revista da Sociedade de Geografia do Rio de Janeiro/SGRJ, 2ºm.1933 p.134

A proposta diz ter enfatizado a criação de territórios em área de fronteira, como emblema da mudança dos aspectos para nova (divisão) ordenamento do Brasil. Afirma como emblema as área de fronteiras pelo baixo grau de densidade demográfica e características - do que denominam de - despolicizadas das mesmas. Afirmam no relatório acreditarem ser possível implementação imediata desses territórios, numa clara visão de acelerar a incorporação de fundos territoriais. Já uma re-ordenação dividindo as demais unidades do País, demoraria tempo mais longe e envolveria outra discussão. Passava-se a ter como prioridade, nacionalizar a fronteira, para resultar em articulação nacional. A justificativa, com argumentos como se de caráter fronteiriço na proposta de criação do Território Federal do Iguaçu, em área considerada, aproximadamente 80.000 km² e o nome - sugerido em 1933 - para a capital seria: Aparecida dos Portos.

A respeito de capital, era também apontado, com um grau de timidez e menor o destaque, a relevância atribuída a uma nova sede de administração e capital brasileira. Embora esteja presente no título do dossiê a discussão da nova localização, poucas linhas são deixadas a esse tema. Não sendo dado destaque de sugestão em edificar nova capital do País, sugerem como a constituição de 1891 afirmava em seu artigo $3^{\circ}$, pertencer a União, no Planalto Central uma área de $14.400 \mathrm{~km}^{2}$ para futuramente demarcar nova sede política e de governança do País. Do ponto de vista econômico, afirmava-se como a transposição da capital ao interior iria dinamizar o rural, além de 
protegê-la de ataques externos, aspecto muito mais vulnerável quando localizada à beira mar como o caso do Rio de Janeiro, capital de então.

Um dos aspectos de continuidade a mais considerar, como tendo sido literalmente implantados na década seguinte a esse dossiê, se refere a subordinação das novas áreas - os territórios - criadas em subordinação direta à União. A proposta da Comissão autora do texto publicado na revista da SGRJ, parece ter sido completamente aceita e levada à cabo e em consideração, 10 anos depois, quando Vargas instala 5 dos 10 territórios sugeridos. Uma das afirmativas propunha: "Os territórios ficarão subordinados à União, que os administrara até que possam obter autonomia política, transformando-se em Província.” (SGRJ, 2ºm., 1933, p.131). Não se propunha autonomia política, quando da criação de tais territórios, pois isso parecia significar a época a criação não de unidades ligadas à nação, mas de potenciais novos regionalismos. Era mais uma vez, a gestão do território, entendido como sinônimo de Brasil, o espaço, e não as pessoas que o fazem.

Por outro lado, aos Estado centrais e de maior consolidação no domínio político e econômico do País, o diagnóstico parece ter temido qualquer proposta de desmembramento. $\mathrm{O}$ mais polêmico não estava em instaurar territórios nas fronteiras Oeste, mas na proposta de fragmentar as "Províncias" existentes. Tais propostas não aparecem, embora se reclame dos gigantismos de uns em oposição aos outros Estados anões.

\section{Sertanismo prévio, prepara a Marcha: contextos para apropriações}

Parte da década de 1930 e com maior destaque na seguinte, 1940, o Oeste brasileiro, genericamente, recebe com maior evidência, a aplicação de projetos envolvidos em movimentos populacionais e fluxos demográficos. Passando uma "reocupação" a ser sobreposta ao habitat existente. ${ }^{149}$ Com característica de "frente" impondo um tipo de fronteira agrícola e de usos de patrimônios naturais coletivos, via a forma de apropriação privada do espaço. Por consequência, apropriação privada de

149 Segundo Álvaro L. Heidrich (2000, p.26) o uso do espaço como condição se sobrevivência, reprodução social e da garantia da moradia seria traduzida na expressão habitat; mas, não significa necessariamente sinônimo de território segundo esse autor: "A localização humana que forma um habitat ainda não é, somente por isso, um território". É necessário apropriação, delimitações de acesso e estabelecimento comunitário para garantir territorialização: "Enquanto a constituição de habitats consiste na recriação da natureza como espaço humanizado, a constituição de territórios significa a instauração do domínio de uma dada civilização sobre a sua existência material em relação à de suas congêneres." (HEIDRICH, 2000, p.26). 
"recursos naturais", circunscritas e constituídos por ocupações de terras em fazendas e transformação em áreas agropastoris. Pode-se dizer, mesmo parecendo em "atraso tecnológico" $" 150$ até a década anterior - a de 1920 - parte relevante do interior do território nacional do País estava sendo, literalmente, ligado pela fiação do telégrafo, cuja figura de Comissão (liderada por Marechal Cândido) Rondon é emblemática. ${ }^{151}$

A nação por um fio, como bem chamou Laura A. Maciel (1999, p.171), quando com a técnica telegráfica programada para conquistar o sertão, "amansar um território ainda virgem", tornar ordenada e produtiva aquelas regiões em que se passava a ter maior contato e comunicação, via telégrafo. Entrou como parte de programas de governos, conquistar o sertão; ainda na Primeira República, aplicando ordem e progresso no/ao espaço. Contexto dos fundos territoriais serem incorporados num acelerado processo de valorização do espaço.

Das vontades, projetos ou desejos de engendrar colonização até década de 1920, quando da implantação de fiação do telégrafo, o ato colonizador passa a desenrolar-se mais constantemente nas décadas seguintes. Uma territorialização foi sendo sobreposta, sob uma lógica de gestão espacial já existente - particularmente, "em cima" de territórios sociais indígenas de acesso livre aos recursos ou, de apropriação comunal/coletiva sem, necessariamente, regramento aos patrimônios naturais passando a territorialidade a ser implementada, antes pelo sertanismo e posteriormente, no processo ficado conhecido com a palavra inicial de marcha: a Marcha para o Oeste. $^{152}$

O sertanismo seria uma primeira verticalidade - pretensamente, racionalizante do século XX, a desembaralhar os territórios sociais (LITTLE, 2004), buscando aplicar algumas dinâmicas para tornar o espaço indutor e promotor do mercado. Tornando a

\footnotetext{
150 "Ainda que superado pela radiotelegrafia, o telégrafo elétrico era considerado por ele [Rondon] o melhor instrumento para incorporação de regiões desertas." (MACIEL, 1999, p.178).

${ }^{151}$ O telégrafo elétrico passou a ser projetado como parte do instrumento de incorporação das áreas consideradas desertas, como afirma Laura A. Macial (1999, p.178): "No Brasil, insistia Rondon, o telégrafo não se desenvolveu, prioritariamente, para diminuir as distâncias na comunicação (agilizando o contato e a troca de informações), mas para penetrar, ocupar e conquistar territórios e povos inspirado nos exemplos dos EUA e na atuação de nações européias e suas possessões coloniais."

${ }^{152}$ Inclusive expressão utilizada para nomear texto de um dos ideólogos - Cassiano Ricardo - do Estado Novo de Getúlio Vargas, no qual será retomada a figura do bandeirante. Para Lucia Lippi Oliveira (2008, p. 15-16): "Com a obra A marcha para o Oeste, de 1940, Cassiano Ricardo estava dando sua contribuição fundamental para a montagem ideológica do Estado Novo. Sabemos que o Estado Novo teve como projeto mudar a imagem do Brasil e do homem brasileiro. Queria criar o homem novo - o trabalhador. A ocupação do interior e a recriação de tipos nacionais fizeram parte do mesmo processo, voltado para criar uma narrativa sobre o trabalhador brasileiro."
} 
terra, por exemplo, valor de mercado. Enquadramentos com regramentos e "normatizações" passam a ser promovidos. Talvez, possa-se até ser um exemplo da sobreposição do "meio técnico-científico" sobre o "meio natural", em que uma das grandes ou, principais alterações socioespaciais, passou a ser o reconhecimento prioritário de um (exclusivo) regime de propriedade.

Numa nova relação com o espaço imposta, desejando tanto imobilizar grupos sociais ali previamente estabelecidos - me refiro principalmente aos indígenas - sob promoção da lógica de fixação de população, através, principalmente, da agricultura. Rompendo-se com lógicas internas próprias das culturas que se reproduzirem no espaço, à medida, em que eram contatados pelos "representantes" da modernidade ou da modernização. Esse momento é da "abertura" do que é colocado como sendo, sertão. Se dado a algum espaço a pecha: sertão, se assim é visto como merecido de condição ou nomeação, deve-se ou projeta-se que seja "desertanizado": como se a "satanice do sertão" fosse nada propício ao ordenamento, nem a modernidade, como já discutido no capítulo anterior (Cap. III), do movimento da incorporação dos fundos territoriais tratados de sertão. Não por acaso, mas para assim "resgatá-los" de uma presenta condição perdida e desarmoniosa. O tratamento de espaços como sertão é uma clara característica de fundo territorial (MORAES, 2005).

A partir ou após as ações ou movimentos do sertanismo, se pensado em etapas, o que nem sempre se dá de maneira ordenada ou "naturalmente desencadeada", mas como "tipos ideais", em seguida ao chão preparado pelo sertanismo, realiza-se "a Marcha". ${ }^{153}$ Previamente a Marcha para Oeste, o movimento sertanista é quem prepara terreno, como se pode concordar dessa interpretação seguinte:

Desbravar, amansar, domar os sertões e tudo que neles havia, inclusive os índios, eram decisões políticas de ocupação e conquista do espaço interior embasadas em desejos de ordem e progresso traduzidos, por sua vez, em atos de força, de vontade de subjugar e dominar e que hoje podem ser sintetizados numa única palavra: "sertanismo". (MACIEL, 1999, p. 185).

As frentes de ocupação e invasão de terras ao Oeste podem ser consideradas em dois momentos temporais relativamente distintos entre si. Uma em decorrência e continuidade do sertanismo, com o propósito discurso de conquista, de manutenção e expansão/asseguramento de espaços oestinos ao território brasileiro. Essa Primeira

\footnotetext{
${ }^{153}$ Para Antonio Carlos Robert Moraes (2005, p.97) “A proposta da 'Marcha para o Oeste' induzia a ideia de uma segunda conquista do território pátrio, animando uma nova onda expansionista agora impulsionada pelo ideal da modernização. Observa-se a incorporação material das 'novas terras' sendo novamente acompanhada pela violência que marca o avanço da frente pioneira, e de novo conhecendo uma apropriação simbólica do processo que o interpreta como uma nova epopeia na construção do país."
} 
Marcha, cobriria período cronológico da ascensão ao poder central do governante sulriograndense (gaúcho) vindo - mesmo que apenas simbolicamente - da fronteira nos anos de 1930 até a construção e, inauguração da nova capital federal no ano de 1960 no Planalto Central. No que se refere ao Território Federal do Iguaçu, tanto esse primeiro movimento sertanista como a colonização com a presença desse mesmo Território parecem se dar mais em paralelos temporais, do que tão esquematicamente separados.

Mas, em seguida, a segunda onda da "marcha" ao Oeste, que não costuma ser assim nominada, se daria pós 1964 com o Golpe Militar até os dias de hoje (?). A característica desse segundo momento passa a ser já em momento muito mais de tecnificação, modernidade e alta produtividade e "rentabilidade com maquinaria" na agricultura, em uma política muito mais liberal, privatista e totalmente voltada ao mercado. Inclusive tendo sido estabelecido expansão colonizadora dessas áreas para aliviar conflitos e tensões agrárias de regiões já mais ocupadas e de consolidação de apropriação mais "antiga". Esse segundo momento, não chego alcançar e nem é proposta da presente pesquisa. Embora não deixe de ser uma separação bastante arbitrária dessas duas ondas das marchas para o Oeste, pois a criação dos cinco territórios federais - aqui um deles tratado - espacialmente todos na fronteira Oeste, abrangiam desde Santa Catarina o mais meridional, até o atual Estado de Roraima, o mais ao norte. Quero dizer com isso, que a separação por critérios espaciais não justificaria tal proposta dos ciclos de marcha como propus. Mas, considerando outros elementos, seja político, econômico e principalmente movimento demográfico, em si, entendo que "do Pantanal acima", quero dizer, ao norte, após inauguração de Brasília e mais ainda do Pós-Golpe Militar, são rupturas e consequências dessa primeira frente ainda sobre batuta do governo Vargas.

Portanto, se o sertanismo consolida uma preparação possibilitando uma Marcha para o Oeste, essa prepara e abre fronteira para a expansão da fronteira do meio-técnicocientifico-informacional de estabelecimentos de propriedades rurais altamente concentracionistas, ao mesmo tempo que ultra modernizadas, voltadas principalmente à produção de commodities. Questão não tratada na presente investigação.

Sobre a Marcha para o Oeste, aliás, vale mencionar, expressão marcha parece condensar nela tanto sentido militar e até mesmo geopolítico - bélico - quanto menção ambivalente ao mito do bandeirantismo e suas entradas em tempos imemoriais, como se súditos da Coroa portuguesa a conquistar espaço, como queria Barão do Rio Branco convencer que assim fosse (aspecto discutido no capítulo II). Antes de marcados por 
fatores produtivos e de alta modernização, o que estou denominando de "primeira onda" da Marcha para Oeste está inserida no contexto de apropriação de áreas, extração madeireira e poderia ser metaforizada como após o fio do telégrafo, e a "fiação" da cerca ou do arame farpado delimitando as possessões. Essa primeira onda acessa pelas portas abertas no sertão pelos sertanistas e aprofunda as ocupações. Porta escancarada, segundo parece ter mencionado Cândido Rondon: "A instalação de uma linha telegráfica exigia uma série de trabalhos complementares que, acreditava Rondon, deixariam 'escancaradas as portas desses sertões, onde dantes não se podia penetrar senão com forte companha armada'." (MACIEL, 1999, p.178)

Se na expansão da fronteira de modernização agrícola da Revolução Verde pós1964 seria o crescimento de produção exponencial de commodities, a marca da primeira onda da Marcha para o Oeste é fundiária, com frentes de expansão buscando estabelecimento de propriedades:

A partir da década de 1930 no Brasil, uma série de movimento migratórios, muitas vezes acompanhados por pesados investimentos em infra-estrutura, modificou de forma contundente as relações fundiárias existentes no país. Esses movimentos espalharam-se por todo o território nacional e atingiram, de uma forma ou de outra forma, os diversos povos tradicionais. A expansão para o oeste do Paraná, nos anos trinte e quarenta, foi seguida pela Marcha para o Oeste, centrada nos Estados de Goiás e Mato Grosso. Nos anos cinquenta desse século [XX], a construção de Brasília, como nova capital federal no Planalto Central, incentivou diretamente o povoamento massivo dessa região. A construção das primeiras grandes estradas teve a função de dar acesso à vasta Região Norte para colonos, garimpeiros, fazendeiros, comerciantes e grandes empresas procedentes de outras regiões do Brasil. (LITTLE, 2004, p.266)

\section{Atos simbólicos e atos falhos? Ordinários e extraordinários no Território}

Gostaria de deixar claro, como no conjunto do material analisado e das reflexões da presente tese, não é a proposta de uma análise na longa duração temporal, ao menos não com apoio em pesquisa em documentação ou empírica. Nem tampouco, uma história territorial total. Não busca cobrir tudo, desde a criação da Capitania Subalterna (1738) tratada no primeiro capítulo, até a criação (1943) e a extinção (1946) do Território Federal do Iguaçu, tema desse presente capítulo. Mas, sim, a proposta é a partir de alguns momentos, circunstâncias no tempo, fazer recortes mais incisivos e ao aprofundá-los (mas, não apenas ou somente com revisão de literatura). Para tanto, no capítulo primeiro se utilizou menos de fontes primárias e mais de uma literatura de segunda mão. Já nos demais seguinte, se tratou de revolver documentos e a partir deles fazer à problemática acontecer; mantendo essa prática no presente $4^{\mathrm{a}}$ capítulo. 
As discussões nos capítulos já passados e o atual são lampejos - flashes - e recortes, com certo grau de arbitrariedade, pois eleitos, tanto como momentos decisivos na construção territorial, também pelas cargas simbólicas marcantes (parecem momentos fundadores). Períodos e temáticas escolhidas, por ajudar a ampliar as reflexões das construções sociais de aspectos geográficos, tais como as territorialidades. Considerando-se, em parte, definidores e, ao mesmo tempo marcantes tanto da construção do território de Santa Catarina, quanto de alguns discursos a respeito dos espaços e intencionalidade que os acompanha, fugindo de um caso, apenas, paroquial.

Então, feita essa ressalva de ser uma proposta de análise em circunstâncias específicas, que uma abordagem desejando incluir mais temáticas e maiores recortes temporal poderia perder ou impedir profundidade. Cada capítulo está mais ou menos enfocando em um período no tempo. Tendo dentre os fios condutores, análise das narrativas e discursos sobre um espaço quase sempre "o mesmo", desde o segundo capítulo: Litígio de Palmas (1895); Sertão do Oeste (1929) e agora o Território Federal do Iguaçu (1946). Pode-se dizer que estamos tratando de camadas sob camadas de tempos diferentes, de uma área que se não é totalmente ou completamente a mesma delimitação, também não deixa de ser diferente. É uma mesma região, e esses processos aqui tratados, também a ajudaram na constituição de alguma unidade, portanto, de regionalização. Mas acima de tudo, reforçam aquela tese na qual afirma (e na qual destaco) como: "A constituição de um território é, assim, um processo cumulativo.". (MORAES, 2005a, p.45). Algumas dessas acumulações territoriais foram aqui tratadas para Santa Catarina.

Embora possa parecer excessiva e forçada comparação, com foco apenas nas continuidades, o objetivo central do presente capítulo foi demonstrar como há relações diretas com demais discussões e temáticas discutidas nos capítulos anteriores. Se poderia dizer que é possível identificar na própria documentação e discursos do período da década de 1940, como mantém, lembram, fazem ilações e/ou remetem a algumas das questões aqui já tematizadas. Vale mencionar: há uma referência ao movimento paulista como de ida ao sertão; de figuras consideradas eminentes ou simbólicas do discurso de instauração da República; uma presença mais constante e rotineira dos EUA e de figuras associadas a esse país. A grande ruptura certamente é o governo Vargas:

Modernizar a economia brasileira, povoando e equipando o território, era uma meta explícita da ditadura varguista, que também fez intensa utilização simbólica da representação do espaço para a legitimação de suas ações. Na visão difundida pelo seu Departamento de Imprensa e Propaganda, o Brasil era 
definido como a somatória de suas culturas regionais e a autenticidade do 'caráter nacional' era localizada nas áreas distantes do interior e, portanto, o sentimento da verdadeira brasilidade residiria nos sertões. (MORAES, 2010, p.67).

Quando da inauguração de um fórum justiça no que era a capital do Território Federal do Iguaçu, um juiz menciona em uma correspondência, ter ocorrido até então, naquela comarca, apenas duas audiências extraordinárias. A terceira a tornar fato seria para inauguração das instalações da autoridade jurídica, em sua sede recentemente edificada. Como já dito, antes desse fato considerado pelo juiz como extraordinário (inaugurar o Fórum da capital do Território Federal), duas outras audiências já haviam sido feitas, entre elas, uma para homenagear o defensor brasileiro na conquista da garantia da posse no litígio de Palmas. Nas palavras do juiz, em “[...] comemoração solene do centenário do nascimento do Barão do Rio Branco, jurista consagrado a quem o Brasil deve a solução pacífica das suas mais rumorosas questões de fronteira." (MOURA, 12-VIII-1946, p.54). E o que mais chama atenção, é fórmula final de despedida, acima do nome juiz. Tal como 40 anos antes, aqueles telegramas comemorando a vitória brasileira na Questão de Palmas (discutidos no capítulo 2 da tese), assim findava correspondência o juiz: Saúde e Fraternidade e seguia o nome do magistrado.

Além da clara saudação inventada por republicanos, o juiz mencionava três eventos extraordinários desde instalação da comarca: o primeiro da chegada da justiça; o segundo da data de nascimento do Barão do Rio Branco e a terceira, a inauguração da sede predial - Fórum - da justiça. Talvez essa forma de homenagear ao Barão do Rio Branco como um fato extraordinário, esteja em não ver a justiça ligada às pessoas, indivíduos com direitos que reconhecem a realização da justiça, mas o evento extraordinário é lembrando a quem garantiu o espaço e a área em que se encontrava tal comarca, como território brasileiro.

Já no que se refere aos nomes de algumas escolas que passam a ser fundadas pelo governo do Território, foram adotados nomes de figuras consideradas ilustres para a história pátria. Trata-se, de ídolos instaurados pelo movimento republicano, como é o caso paradigmático da figura do Tiradentes. O governador do Território Federal baixa um decreto $\left(\mathrm{n}^{\circ} 2\right)$, no dia do feriado 21 de abril, passando a nomear a escola de formação para magistério, de Escola Tiradentes. Portanto, nesse período, mesmo parecendo uma grande ruptura com Vargas, há também continuidades entre discursos republicanos. 
Por outro lado, o coronelismo e patrimonialismo continuaram campeando, mesmo após a extinção do território, ou melhor, junto desse próprio processo, como se quando do momento de passar os bens federais para as entidades municipais e estaduais.

Era 31 de março de 1947. Iguaçu, já não é mais capital do Território Federal (com o mesmo nome), mas pertencente ao Estado do Paraná. Chegara o momento de finalizar as listagens com as demonstrações dos destinos das entregas e encaminhamentos dos bens móveis e imóveis, que até então pertenciam ao (recém extinto) Território Federal do Iguaçu. O (ex-)governador dali, já havia retornado à capital Federal. E o presidente da Comissão de Inventário e Entrega dos Bens Territoriais - Hélio Moreira - parece se ver em apuros. Já não parecendo mais haver autoridades presentes, o poder de quem tem mais força, parece prevalecer. Uma espécie de representante do governador fica pela região para fazer o levantamento das entregas e organizar relatórios a respeito do destino dos bens. Faz um detalhado ofício com inventário e respectivos termos de responsabilidades, dizendo do destino desses bens. Encaminha descrição ao ex-governador que por sua vez re-encaminhou ao Ministério da Justiça.

O relator do ofício sugere ao ex-governador, que o mesmo consiga um fiscal para acompanhar as entregas e o cuidado dos bens. Para tanto, diz da necessidade de acionar o Ministério da Justiça. Por qual razão, seria, a necessidade da vinda de um fiscal para averiguar a recepção do patrimônio da União agora passando para os municípios? Tal necessidade de ampliar controle e vigilância se devia pelo fato do patrimônio público, que estava indo de acordo com a lei, para as mãos dos novos responsáveis, estava nesse processo sendo dilapidado. "Por esta razão, sugiro a V. Excia.", afirmava o autor do relatório, "interceder junto ao Exmo. Sr. Ministro da Justiça e Negócios Interiores para a designação de um fiscal do patrimônio Federal junto às Prefeituras." (MOREIRA, 31-III-1947, p.120). Entre as justificativas ao pedido de um agente do Estado para acompanhar as transmissões de bens federais se devia, segundo afirma o mesmo documento "algumas Prefeituras estão dispondo do material recebido para diversos fins, apesar da circunstância de depositários e caráter de responsabilidade.” (MOREIRA, 31-III-1947, p.119).

O fim do território, não significa que algumas políticas, bens e formas de administração teriam continuidade. Ao contrário, pois, mesmo com aporte de estruturas da União ali feita, ao que parece, não foi apenas o fim do território, mas também se serviços e presença do Estado (de maneira geral). Na passagem desses bens, segundo é 
relatado pelo presidente da comissão do inventário: "Já houve caso de Prefeito determinar venda de material a particulares." (MOREIRA, 31-III-1947, p.119).

Dos bens, mobiliários públicos construídos - como prédios de escolas, postos de atendimento público - e infra estrutura ali realizada pelo governo federal, o caso mais contundente entre os relatados, está o do delegado que literalmente ocupou a rádio da capital, sem o menor pudor. Chegando então a se tornar impossível ao funcionário do Estado federal (do ex-Território), conseguir passar a rádio, pois havia sido completamente tomada pelo delegado local, segundo apontar relatou o responsável pelo inventário: "A estação de rádio transmissora não foi entregue mediante termo de responsabilidade em virtude da mesma, ter sido ocupada pelo delegado regional de polícia do Iguaçu, Capitão Boileau Vandick da Silva Sidreira em 18 de janeiro de $1947 ”$.

Sabendo dos fatos das realocações das estruturais federais para os entes responsáveis, seja município, Estado etc..., ao delegado foi negado entregar-lhe a estação de rádio que solicitava, como explicou o funcionário: “[...] em virtude de não haver recebido ordens de entrega, razão pela qual foi a mesma ocupada, quase militarmente, pela autoridade policial já referida.” (MOREIRA, 1947, p.188). Devido tal domínio feito pelo delegado, "da referida estação rádio transmissora", o funcionário responsável por inventariar e informar das responsabilidades assumidas pelas instituições resolveu então, protocolar legalmente como estando em posse do delegado "apresentados à autoridade policial mencionada para a referida assinatura, tendo a mesma recusado em fazê-lo".

\section{Onipresença estadunidense ou uma face da norteamericana no território?}

Talvez possa parecer no mínimo curioso, ou até muito estranho ter sido feita alguma associação com os Estados Unidos passados quase 50 anos da arbitragem em favor do Brasil na fronteira com a Argentina (tema do Capítulo II). Quem se remeter apenas a literatura produzida sobre a temática do Território Federal do Iguaçu, pouca referência direta parecerá ao País da América do Norte. Percepção diferente tem quem vê jornais dos anos da década de 1940. Observando as fontes do período (1943-46), observa-se constante menção à variados "aspectos estadunidenses".

Como se nota na imprensa escrita, mantinha-se regularidade de notícias veiculadas (e associações deliberadas) a fatos dos EUA. Aspectos da cultura política brasileira pareciam tratados como se em prisma estadunidense. E não foi diferente no 
caso da criação de cinco território federais em 1943, espaços colocados sob gerência direta na esfera da administração da união, em um momento marcante de centralização. Se um jornal apontava em seu texto o histórico da Estátua de Liberdade ${ }^{154}$ ter sido inaugurada pelo presidente Cleveland, numa espécie de "ato inaugural" universal, uma propaganda de publicidade trazia imagem do rosto desse presidente estadunidense não para falar do seu papel como árbitro da fronteira com Argentina, mas como uma espécie de garoto propaganda na publicidade comercial. Em desenho apontando como sendo Grover Cleveland e um trecho de um depoimento atribuído a ele, buscava-se convencer pessoas a fazerem seguro. Uma seguradora publicava dizendo como concepção preventiva e dramática da necessidade de precaver-se do destino, a inteligente decisão do ex-presidente dos EUA. Aos chefes de famílias cabia resguardar-se dos azares da vida, evitando deixar familiares mendicantes; para isso, bastava planejar-se. Se havia marca ou recomendação deixada por Cleveland, seria na propaganda: fique segurado de ninguém precisar dar esmola aos seus!

\section{Menção em jornal O'Estado (Florianópolis) de Ex-Presidente dos EUA, publicidade}

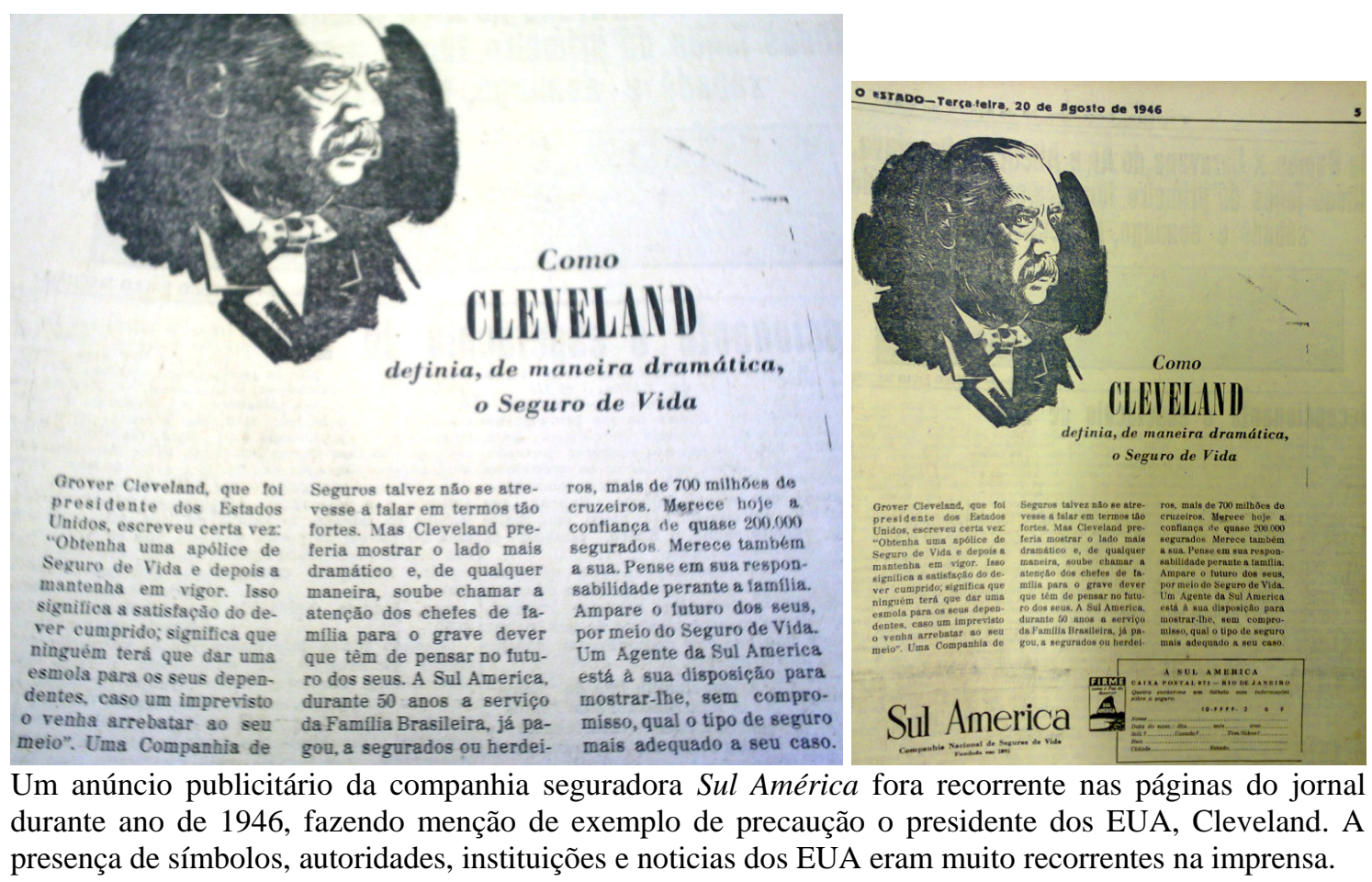

\footnotetext{
154 A menção ao presidente Cleveland como inaugurador do presente da França aos Estados Unidos apareceu no mínimo duas vezes no Jornal O'Estado, 5ª feira 02 de dezembro de 1943, p. 07 (como segue um trecho): "Desde que o Presidente Grove Cleveland inaugurou-a em 28 de outubro de 1886, ela tem sido o grande marco da liberdade e o monumento que resume as esperanças e aspirações do gênero humano." (O’ESTADO, 02/XII/1943, p.07)
} 
Um município do Paraná já tinha, desde 1909, alterado o nome em pretensa homenagem ao presidente votante do litígio para o Brasil, em uma toponímia digna da mais desconfortável estética e de gosto duvidoso, ficado registrado Clevelândia (PR). 


\section{CONSIDERAÇÕES FINAIS}

$\mathrm{O}$ argumento da presente tese, buscou a partir de momentos diferentes, tratar sobre discursos a respeito dos espaços, a partir de diferentes ângulos e pontuando alguns usos que se faziam, intencionalidades e interesses. Uma das linhas de condução que perpassam todos os capítulos está em rituais de fundação ou atos de inauguração perpassam vários das temáticas aqui tratadas: da certidão de nascimento "criando" a capitania da Ilha Santa Catarina, seja do ganho de causa no litígio de fronteira com a Argentina; a Viagem de um governante como um bandeirante a inaugurar áreas para Santa Catarina, incorporando-a "definitivamente". Seja ainda a criação e extinção do território federal.

A tese busca entender, como resultado de uma base de colonização portuguesa, juntando áreas de duas dinâmicas, uma do interior (circuito dos caminhos das tropas) do Planalto paulista e outra circunscrição litorânea de base territorial militar de defesa, deram um tom bastante lento e difícil na integração catarinense. Aliás, a integração buscada em primeiro plano era do espaço: organizar uma disposição territorial, seria sinônimo de conseqüente criação de uma comunidade imagina catarinense. Esse processo falho (talvez até hoje incompleto), lento e resultado de construções sociais, se exprime muito bem na dificuldade da capital de Estado (Desterro e depois da República, Florianópolis) se impor. Durante muito tempo demais regiões não se identificaram com a capital, nem chegavam a ela ou buscam acessá-la.

A letigimidade em tratá-la conceitualmente como uma rugosidade, não se deve apenas ao fato de uma pesquisa em Geografia Histórica averiguar temporalmente sua invenção como espaço de poder, mas como ao longo do tempo foi contestada e a mesmo assim resistiu. Vindo do resultado natural de sua localização e condição geomorfológica, influente no circuito da navegação e se poderia dizer simbolicamente, até 1680 (ano fundação da fortificada Colônia do Sacramento), central na territorialidade marítima dos mares do sul, passa a ser também colocada como uma espécie de centro agora em uma territorialidade militar nas fronteiras meridionais da América portuguesa.

Para melhor compreender o por que de ser ali nessa Ilha de Santa Catarina uma sede de poder, é preciso retornar às condições e concepções da época colonial, e por isso, uma ruga, por durar mais do que as condições que a consideraram central, há uma decadência e extinção daquele tipo de circuito marítimo que a tornam super relevante 
nas rotas das navegações, há extinção das disputas e conquistais ibero americanas; a própria fortificação da ilha é testada menos de 5 décadas antes da Independência e Portugal a faz útil, com prédios e construções que são rugosidades até hoje presentes, como fortificações e certamente influenciaram tais construções na manutenção da sede de governança, mas certamente houveram outros fatores a continuar.

O fato de que os discursos sobre os espaços (os discursos a respeito das espacialidade) quase nunca são separados das intencionalidades que se deseja fazer uso deles. As concepções que se fazem dos espaços não são sem intenções, e isso pode ser observado tanto em cidades que desconfiam da capital continuar como sede na Ilha requerendo transferir sede administrativa, mas também podemos observar nesse trabalho como um engenheiro geógrafo cartógrafo se utilizou da mensuração, do trabalho de conhecer, saber, medir e controlar melhor um espaço como meios de galgar postos, confiança, símbolos e capitais para si e seus filhos. Discutiu-se também como a centralidade da noção de território do País como quase sinônimo de Brasil, acaba por eleger heróis nacionais muito relacionado à manutenção, conquista, alargamento e domínio de fundos territoriais, fronteiras e ganhos de área. $\mathrm{O}$ caso paradigmático é do Barão do Rio Branco, mas perpassa também Barão do Capanema, Marechal Cândido Rondon, Getúlio Vargas, e um governador bandeirante como dizia ser, Adolfo Konder.

Heróis territoriais recebem uma carga tão relevante de influencia e simbolismo na identidade nacional pelo fato da centralidade ao espaço e o peso do território na concepção de Brasil ser tanto autoritária porque distribuído desigualmente o acesso ao mesmo, como também por impor territórios sem levar em conta às comunidades, pessoas, enfim, de ser resultado da cidadania, mas de às vezes, cassar a participação popular nos destinos às gestões do espaço. A república faz um uso do espaço como simbólico para impor uma maior capilaridade e reconhecimento popular, embora em seu início tenha defendido doar área para Argentina, com o resultado do litígio as comemorações são justamente o inverso dessa.

Pode-se dizer que se tentou abordar várias camadas de sentidos, interpretações, concepções e discursos sobre uma área relativamente comum. Camadas de discursos espaciais e concepções territorializadas ao longo do tempo em uma mesma região a de Palmas (Missiones); o Sertão da Fronteira Oeste; a área do Contesto; o Território Federal do Iguaçu. Menos um estudo cronológico, buscou-se atingir momentos, cenas, de formulações e formações territoriais em Santa Catarina. Alguém poderia argumentar que o fio condutor de todos os capítulos tenha sido menos o tempo e mais até, um autor: 
Antonio Carlos Robert Moraes e um debate direto com suas análises. Tal argumento é em parte verídico e legítimo, mas não só. Menos como rupturas e continuidades, nem como apenas mudanças e permanências, a proposta foi mais de entender uma questão: espaço e poder.

A emergência do território de Santa Catarina, passa pela emergência de concepções territorializadas de País, de concepções espacializadas da sociedade, desde o incentivo à criação de colônias para fazer integrar os opostos mundos do Planalto e do Litoral. Emergência Santa Catarina na época colonial, mas emergência em paralelo e posteriormente outras territorialidades, seja da navegação, seja dos caminhos das tropas, seja com a construção da ferrovia São Paulo - Rio Grande. Há sim, uma emergência de base territorial marcante, com a criação da capitania subalterna, definidor para os estudos de Geografia Histórica desse espaço. Mas houveram outras características e concepções que não devem ser desprezadas e que se movem nessa tentativa de fazer Santa Catarina existir, arrumar a casa, seria literalmente, fazer arrumações dos edifício da casa e quase muito pouco (ou quase nunca) aparecem os moradores, habitantes, condôminos e gente que afinal, dá sentido e coloca em movimento o território. Os espaços são colocados em contatos pelas pessoas, já bem lembrar Antonio Carlos R. Moraes; sem vida social, o espaço não existe. Fazer integrar espaços com geografias físicas de baixa ou pouca comunicação entre si pelos relevos e bacias hidrográficas, parece nunca ter conseguido plenamente ter se alcançado. Sinal de quem não basta apenas fazer com que o território seja favorável à circulação, conexão ou livre fluxo, é preciso com que as pessoas se sintam parte dele, construtoras e o atribuam sentidos, como pertencentes plenos que deveriam ser. Menos heróis territoriais, deveríamos ter uma maior plena cidadania territorial, reconhecimento efetivo e jurídico dos territórios sociais. Construir para integrar, não significa construir o território para fazer integração, mas possibilitar as pessoas serem plenamente agentes do espaço e sintam a vida como parte deles. 


\section{REFERÊNCIAS}

\section{(Alguns Documentos)}

ANSON, George. "Capítulo III. ANSON, 1740". In: HARO, Martim A. Palma de (Org). Ilha de Santa Catarina. Relatos de viajantes estrangeiros nós séculos XVIII e XIX. Florianópolis: Ed. da UFSC; Ed. Lunardelli, 1996. pp.57-72.

BETAGH, William. "Capitulo II. BETAGH, 1719". In: HARO, Martim A. Palma de (Org). Ilha de Santa Catarina. Relatos de viajantes estrangeiros nós séculos XVIII e XIX. Florianópolis: Ed. da UFSC; Ed. Lunardelli, 1996. pp.49-56.

FRÉZIER, Amédée François. "Capítulo I. FRÉZIER, 1712". In: HARO, Martim A. Palma de (Org). Ilha de Santa Catarina. Relatos de viajantes estrangeiros nós séculos XVIII e XIX. Florianópolis: Ed. da UFSC; Ed. Lunardelli, 1996. pp.15-28.

PERNETTY, Antoine Joseph. "Capítulo IV. Dom Pernetty, 1763." In: HARO, Martim A. Palma de (Org). Ilha de Santa Catarina. Relatos de viajantes estrangeiros nós séculos XVIII e XIX. Florianópolis: Ed. da UFSC; Ed. Lunardelli, 1996. pp.75-85.

SHELVOCK, George. "Capítulo II. SHELVOCKE, 1719." In: HARO, Martim A. Palma de (Org). Ilha de Santa Catarina. Relatos de viajantes estrangeiros nós séculos XVIII e XIX. Florianópolis: Ed. da UFSC; Ed. Lunardelli, 1996. pp.29-48.

BOITEUX, José Arthur. OESTE CATHARINENSE (De Florianópolis a Dionísio Cerqueira). Conferência realizada no Centro Catharinense, na Sociedade Geográfica (Rio de Janeiro) e no Club XII de Agosto (Florianópolis) em 1929. Florianópolis: Livraria Central de Alberto Entre e Irmãos, 1931.

CASAL, Manuel Aires de. Corografia Brasílica ou Relações Histórico-Geográfica do Reino do Brasil. São Paulo: Edições Cultura, 1943.

COSTA, Arthur Ferreira da. O OESTE CATHATINENSE. Visões e suggestões de um excursionista. Rio de Janeiro: Villas Boas Cia., 1929.

D'EÇA, Othon. AOS ESPANHÓIS CONFINANTES. $2^{\mathrm{a}}$ Ed. Florianópolis: Fundação Catarinense de Cultura/FCC; Ed. UFSC/; Fundação Banco do Brasil/FBB, 1992. [1ª edição ano de: 1929]

KONDER, Adolpho. Relatório apresentado ao Hercílio Pedro da Luz por Adolpho Konder. Secretaria da Fazenda, Viação, Obras Publicas e Agricultura, em 1 de maio de 1919. Florianópolis.

Programa de governo. Lido no banquete de 18 de setembro de 1926, em Florianópolis. Imprensa Oficial,

Estado de Santa Catarina, Mensagem apresentada ao Congresso Representativo, 29 de julho de 1927. Florianópolis.

Estado de Santa Catarina, Mensagem apresentada à Assembléia Legislativa 29 julho de 1928. Florianópolis. 
ODEBRECHT, Rolf. (Org). Cartas de família: ensaio biográfico de Emil Odebrecht e ensaio biográfico de seu filho Oswaldo Odebrecht. Blumenau: Edição do autor, 2006.

PEDERNEIRAS, Haroldo Paranhos. Plano Rodoviário Catarinense. Trabalho apresentado ao 6 Congresso Nacional de Estradas de Rodagem. Florianópolis: Imprensa Oficial do Estado, 1936. (republicado em 1939, com mapas)

RAMOS, Vidal J. de Oliveira. Mensagem apresentada ao Congresso Representativo em 24 de julho de 1904, pelo Vice-Governador Vidal José de Oliveira Ramos. Estado de Santa Catarina.

Revista Blumenau em Cadernos, vários volumes e vários tomos. Blumenau (SC).

Revista Blumenau em Cadernos, tomo II, janeiro de 1960, n.01.

RIO BRANCO, Barão. Obras do Barão do Rio Branco I: Questão de Limites, República Argentina. Brasília: Fundação Alexandre de Gusmão, 2012.

SCHMIDT, Felippe. Mensagem do Governo de Santa Catarina, governador Felippe Schmidt. 14 de agosto de 1916. Estado de Santa Catarina.

\section{Referências bibliográficas}

ABREU, Maurício de Almeida. Geografia Histórica do Rio de Janeiro. Rio de Janeiro: Prefeitura municipal do RJ, 2010.

ALBUQUERQUE JUNIOR, Durval Muniz de. A invenção do nordeste e outras artes. Recife: FJN, Ed. Massangana; São Paulo: Cortez, 1999.

"O Objeto em Fuga: algumas reflexões em torno do conceito de região." Revista Fronteiras. Dourados/MS, v. 10/17, p. 55-67, 2008.

"Às margens d'O Mediterrâneo. Michel Foucault, historiador dos espaços." In: ALBUQUERQUE JUNIOR, Durval Muniz de; VEIGA-NETO, Alfredo; SOUZA FILHO, Alípio de Souza (organizadores). Cartografias de Foucault. $2^{\mathrm{a}}$ ed. Belo Horizonte: Autêntica Editora, 2011. pp. 93-105.

. "O Tempo, o Vento, o Evento: história, espaços e deslocamentos nas narrativas de formação do território brasileiro." XXIV Simpósio Nacional de História ANPUH - São Leopoldo (RS), 2007; Unissinos (Universidade do Vale do Rio dos Sinos).

ALENCASTRO, Luis Felipe de. Tratado dos Viventes. São Paulo: Companhia das Letras, 2000.

ALVES FILHO, Ivan. História dos Estados brasileiros. Rio de Janeiro: Ed. Revan, 2000.

AMADO, Janaína. "Região, Sertão, Nação." Ver. Estudos Históricos, vol.8, n.15, 1995, Rio de Janeiro. p.145-151.

ANDERSON, Benedict. Comunidades imaginadas. Reflexões sobre a origem e a expansão do nacionalismo. Lisboa: Edições 70, 2005.

"Introdução". In: BALAKRISHNAN, Gopal (Org). "Um mapa da questão nacional".

Rio de Janeiro: Contraponto, 2000. pp. 07-22 
ARAÚJO, Hermetes Reis de. "O discurso da integração". In_. "A invenção do litoral. Reformas Urbanas e Reajustamento Social em Florianópolis na Primeira República." Dissertação (Mestrado em História) PUC/SP, 1989. Pontifícia Universidade Católica de São Paulo.

ARRUDA. Gilmar. "Rios, navegação, ferrovias e a construção do território do Paraná." In: (Org). A Natureza dos Rios: história, memória e territórios. Curitiba: Editora da UFPR, 2008. pp.95-136.

. Cidades e Sertões. Entre história e memória. Bauru (SP) : Edusc, 2000.

ARANHA, Bruno P. de Lima. De Buenos Aires a Misiones: civilização e barbárie nos relatos de viagens científicas realizadas à terra do mate (1881-1901). Dissertação (Mestrado) PROLAM: Programa de Integração Latino Americana, USP. 2014. São Paulo.

ATHANÁZIO, Enéas. "O Estado do Iguaçu e a mudança da capital." Revista Blumenau em Cadernos, Tomo XXXIII. Nov/Dez de 1992 pp. 423-424, n¹1-12. Blumenau.

AURAS, Marli. A Guerra do Contestado: organização da irmandade cabocla. $4^{\circ}$ ed. Florianópolis: Ed. da UFSC, 2001.

AZEVEDO, Aroldo de. "Vilas e Cidades do Brasil Colonial. Ensaio de geografia urbana retrospectiva." São Paulo: Boletim da FFLC n²08, da Geografia nº.11. 1956

BALDIN, Nelma. A Intendência da Marinha de Santa Catarina e a questão da Cisplatina. Florianópolis: Fundação Catarinense de Cultura/FCC, 1980.

BARRETO, Cristiane M. "Entre Laços e Nós. Formação e atuação das elites no Vale do Itajaí (1889-1930)." Dissertação Mestrado História UFRGS, Porto Alegre, 1997.

BAUER, Otto. "A Nação". In: BALAKRISHNAN, Gopal (Org). "Um mapa da questão nacional". Rio de Janeiro: Contraponto, 2000. pp.45-83.

BOURDIEU, Pierre. "A identidade e a representação: elementos para uma reflexão crítica sobre a identidade da região." In: O poder simbólico. 6.ed. Rio de Janeiro: Bertrand Brasil, 2003. pp.107-132.

BRANDT, Marlon. Uma História Ambiental dos campos do planalto de Santa Catarina. Tese (doutorado) História UFSC-CFH, Florianópolis. 2012.

BRAUDEL, Fernand. Civilização material economia e capitalismo: séculos XV-XVIII. (volume 3) São Paulo: Martins Fontes, 1996.

. Identidade da França. Rio de Janeiro: Ed. da Globo, 1989.

BRÜGGEMANN. Adelson André. Ao poente da Serra Geral: a abertura de um caminho entre as capitanias de Santa Catarina e São Paulo no final do século XVIII. Florianópolis: Editora da UFSC, 2008.

CABRAL, Owaldo Rodrigues. História de Santa Catarina. Florianópolis: Secretaria Estadual de Educação, 1968.

CAMPOS, Cynthia Machado. "Diversidade e integração." In:_. Santa Catarina, 1930: da degenerescência à regeneração. Florianópolis: Ed. da UFSC, 2008. pp.59-104 (capitulo 2). 
CAMPOS, Emerson César de. "O Catarinense de Bombacha: Movimento Tradicionalista Gaúcho em Santa Catarina (1959-1997)”. 1999. Dissertação (Mestrado em História), CFH, UFSC. Florianópolis.

CARDOSO, Ciro Flamarion. "Repensando a construção do espaço". In:_. Um historiador fala de teoria e metodologia: ensaios. Bauru (SP): Edusc, 2005. pp.37-52. (capitulo 2)

CARDOSO, Vitor H. Bastos. As dinâmicas político-territoriais de uma comunidade periférica no sul da América Portuguesa: a ilha de Santa Catarina e seu continente, 1680-1750. Dissertação (Mestrado em História) Universidade Federal de Santa Catarina - UFSC. Centro de Filosofia e Ciências Humanas-CFH, 2013. Florianópolis.

CASTRO, Iná Elias de. O mito da necessidade. Discurso a prática do regionalismo nordestino. Rio de Janeiro: Bertrand Brasil, 1992.

CARVALHO, José Murilo. "Contextualizando o contestado." In: WEHKING, Arno (et al.) Florianópolis: MPSC, 2013. pp.21-30.

Formação das Almas. O imaginário da República no Brasil. São Paulo: Companhia das Letras, 1990. (segunda reimpressão)

CLAVAL, Paul. A geografia cultural. Tradução de Luiz F. Pimenta e Maragareth de Castro A.

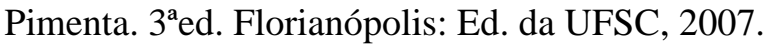

."Uma, ou algumas abordagem(ns) na geografia humana.” In: SERPA, Â (Org). Espaços Culturais: vivências, imaginação e representações. Salvador: EdUFBA, 2008. pp.13-29.

CEOM/Centro de Memória do Oeste de Santa Catarina (Org.) A viagem de 1929: Oeste de Santa Catarina, documentos e leituras. Chapecó: Argos, 2005.

CONTEL, Fábio B. "As divisões regionais do IBGE no século XX, (1942, 1970, 1990)." Terra Brasilis (Nova Série) [Online], 3| 2014, posto online no dia 26 Agosto 2014, pp. 02-17.

. O Mediterrâneo de Fernand Braudel: diálogos possíveis com o pensamento geográfico." Anais do II Encontro Nacional de História do Pensamento Geográfico. pp.199-218

CORRÊA, Nereu. “Adolpho Konder, o homem e o político.” In:_. Perfis e retratos em vários tons (In Memoriam). Florianópolis: Ed. da UFSC/ Ed. Lunardelli, 1986. pp.61-64.

CORRÊA, Carlos Humberto. Um Estado entre duas repúblicas. A revolução de trinta e a política em Santa Catarina. Florianópolis: Editora da UFSC/Assembléia Legislativa de Santa Catarina/ALESC, 1984.

"1929, Adolpho Konder e a Descoberta do Oeste Catarinense." In: História da Cultura catarinense. O Estado e as idéias, volume 1. Florianópolis: Editora da UFSC; Diário Catarinense, 1997. pp.179-194.

CORTESÃO, Jaime. A fundação de São Paulo, capital geográfica do Brasil. Rio de Janeiro: Livros de Portugal, 1955.

COSTA, Angela M. da; SCHWARCZ, Lilia Moritz. 1890-1914 no tempo das certezas.São Paulo: Companhia das Letras, 2000. 
DALLABRIDA, Norberto. "A perspectiva histórica de Cabral em 'História de Santa Catarina'." Revista Blumenau em Cadernos tomo XXXIII agosto 1992 pp.240-247. nº, Blumenau.

DIAS, Leila Christina; RAUD, Cécile. (Org). Villes et Régions au Brésil. Paris: L'Harmattan, 2000.

DELSON, Roberta M. Novas Vilas para o Brasil-Colônia. Planejamento Espacial e Social no Século XVIII. Brasília: Edições Alva; CIORD, 1979.

FALCÃO, Luiz Felipe. Entre o ontem e amanhã: diferença cultural, tensões sociais e separatismo em Santa Catarina no século XX. Itajaí (SC): Editora da UNIVALI, 2000.

FEBVRE, Lucien. O Reno: história, mitos e realidades. Tradução Eliana Aguiar. Rio de Janeiro: Civilização Brasileira, 2000.

FERNANDES DE SOUSA NETO, Manoel. Planos para o Império: os planos de viação do Segundo Reinado (1869-1899). Tese (Doutorado) Geografia Humana, FFLCH, USP, 2014.

FLORES, Bernadete Ramos. A farra do boi: palavras, sentidos, ficções. 2.ed. Florianópolis: Ed. da UFSC, 1998.

; SERPA, Élio Cantalício. "A hermenêutica do vazio: fronteira, região e brasilidade na viagem do governador ao Oeste de Santa Catarina." In: A viagem de 1929: Oeste de Santa Catarina, documentos e leituras. Chapecó: Argos, Centro de Memória do Oeste de Santa Catarina/CEOM, 2005. pp. 129-153.

FOUCAULT, Michel. "A governamentalidade.” In:_. Microfisica do poder. Rio de Janeiro: Graal, 1979. pp.277-293.

Segurança, território, população. São Paulo: Ed. Martins Fontes, 2008.

FRIDMAN, Fania; HAESBAERT, Rogério (Orgs). Mauricio de Almeida Abreu, Escritos sobre espaço e história. Rio de Janeiro: Garamond, 2014.

GAPLAN / Gabinete de Planejamento e Coordenação Geral do Governo de Santa Catarina. Atlas de Santa Catarina. Rio de Janeiro: Aerofoto Cruzeiro; Florianópolis: Subchefia de Estatística, Geografia e Informática, 1986.

GOULATI FILHO, Alcides. Formação econômica de Santa Catarina. 2ed. Florianópolis: Editora da UFSC, 2007.

GENOVESE, Eugene. A terra prometida: o mundo que os escravos criam. Petrópolis (RJ): Ed. Paz e Terra, 1988.

GREGÓRIO, Vitor M. "A emancipação negociada: os debates sobre a criação da província do Paraná e o sistema representativo imperial, 1843.” Revista brasileira de História. São Paulo, v.35, $\mathbf{n}^{\mathbf{0}} \mathbf{6 9}, \mathrm{pp} .319-341,2015$.

"A criação da Província do Paraná: uma agenda de pesquisa." IV Congresso Internacional de História 09-11 de setembro 2009. UEM, Maringá-PR.

HAESBAERT, Rogério. “'Gaúchos' e Baianos no 'novo' nordeste: entre a globalização econômica e a reinvenção das identidades territoriais." In: CASTRO, Iná Elias de; GOMES, Paulo César da Costa; CORRÊA, Roberto Lobato (Orgs). Brasil: questões atuais da reorganização do território. Rio de Janeiro: Bertrand Brasil, 1996. pp.367-415. 
. "Dilema de Conceitos: Espaço-território e contenção territorial." In: SAQUET, M. A.; SPOSITO, E. S. (Orgs). Território e territorialidades: teorias, processos e conflitos. São Paulo: Ed. Expressão Popular; Programa de Pós-Graduação em Geografia/UNESP, 2009. pp.95120.

HARO, Martim A. Palma de. (Org). Ilha de Santa Catarina: relatos de viajantes estrangeiros nos séculos XVIII e XIX. 4ed. Florianópolis: Ed. da UFSC; Ed. Lunardelli, 1996.

HARVEY, David. Para entender $\boldsymbol{O}$ CAPITAL, Livro I. Trad. Rubens Enderle. São Paulo: Boitempo, 2013.

HEIDRICH, Álvaro Luiz. Além do latifúndio: geografia do interesse econômico gaúcho. Porto Alegre: Ed.Universidade/UFRGS, 2000.

"Aspectos culturais e ideológicos da construção da regionalidade gaúcha." In: VERDUM, Roberto; BASSO, Luis Alberto e SUERTEGARAY, Dirce Maria Antunes (organizadores). Rio Grande do Sul: paisagens e territórios em transformação. Porto Alegre: Editora da UFRGS, 2004. pp.215-232.

HEINSFELD, Adelar. "As ações Geopolíticas do Barão do Rio Branco e seus reflexos na Argentina.” Tese (doutorado em História) PUC-RS, Porto Alegre, 2000.

HENRICH, Nathália. "As relações Brasil-Estados Unidos no pensamentos político do Barão do Rio Branco." Dissertação de mestrado em Sociologia Política, CFH/UFSC, Centro de Filosofia e Ciências Humanas da Universidade Federal de Santa Catarina, 2010. Florianópolis.

HOBSBAWM, Eric. "Etnia e Nacionalismo na Europa hoje." In: BALAKRISHNAN, Gopal (Org). Um mapa da questão nacional. Rio de Janeiro: Contraponto, 2000. pp.271-282.

"Introdução: A Invenção das Tradições." In: HOBSBAWM, Eric; RANGER, Terence (Orgs). A invenção das tradições. Rio de Janeiro: Paz e Terra, 1997, pp. 09-23.

HOLANDA, Sérgio Buarque. "Do Bandeirante ao Tropeiro." Revista Rumo, Ano I, $3^{\circ}$ trimestre 1943 - $\mathbf{n}^{\circ}$ 2, vol. 1. (Casa do Estudante do Brasil). pp.04-12.

Caminhos e Fronteiras. 3 ed. São Paulo: Companhia das Letras, 1994.

HÜBENER, Laura Machado; BARRETO, Maria Theresinha Sobierajski. "Contribuição para o estudo da integração catarinense.” [S. 1.]: s.n., 1988?] Não paginado.

IANNI, Octavio. A sociedade global. 12.ed. Rio de Janeiro: Civilização Brasileira, 2005.

IBGE/Instituto Brasileiro de Geografia e Estatística. Enciclopédia dos Municípios brasileiros XXXII Volume, Municípios do Estado de Santa Catarina. Rio de Janeiro: IBGE, 1959.

JAMUNDÁ, Theobaldo Costa. "Ao redor do Dr. Blumenau." Revista Blumenau em Cadernos, Tomo XXXIII. Nov/Dez de 1992 pp.417-420. n¹1-12. Blumenau.

JEAN, Bruno. "Le développement territorial: um nouveau regard sur lês régions du Québec." Recherches sociographiques, volume XLVII, n. 3, septembre-décembre 2006. pp.465-474.

JENKINS, Keith. A História Repensada. 4aedição. São Paulo: Ed. Contexto, 2013. 
KANTOR, Iris ; BUENO, Beatriz P. Siqueira ; FERLINI, Vera Lúcia A. "Dossiê em rede : cartografia vivida e razão de Estado no Século das Luzes." Anais do Museu Paulista. São Paulo n. Sér. V.17 n.2 pp.11-15 jul-dez. 2009.

KUNTZ, Jackson D. Uma capital vacilante : Estado e relações políticas em Santa Catarian - a proposta de transferencia da capital para o interior (1988-1991). Dissertação de Mestrado (História), 2013. Universidade do Estado de Santa Catarina (UDESC), Florianópolis.

LAGO, Paulo Fernando. "A terra e o homem”. In: SANTOS, Sílvio Coelho dos (Org). Santa Catarina no século XX: ensaios e memória fotográfica. Florianópolis: Ed.UFSC/FCC Edições, 2000. pp.62-90.

LATOUR, Bruno. Jamais fomos modernos. Ensaio de antropologia simétrica. Rio de Janeiro: Ed. 34, 1994.

LENCIONE, Sandra. Região e Geografia. São Paulo: editora da USP, 1999.

LESSER, Jeffrey. A negociação da identidade nacional. Imigrantes, minorias e a luta pela etnicidade no Brasil. Trad. Patrícia de Q. C. Zimbres. São Paulo: Ed. UNESP, 2001.

LIMA, Débora da Rosa R. A Abordagem ambiental no planejamento urbano de Florianópolis. Dissertação (Mestrado) Faculdade de Arquitetura e Urbanismo-FAU. USP, 2003.

LIRA, Larissa Alves de. O Mediterrâneo de Vidal de la Blache. O primeiro esboço do método geográfico (1872-1918). São Paulo: Alameda, 2013.

LITTLE, Paul E. "Território sociais e povos tradicionais no Brasil: por uma antropologia da territorialidade." Anuário Antropológico 2002-2003. Rio de Janeiro: Tempo brasileiro, 2004. pp. 251-290.

LOHN, Reinaldo Lindolfo. "Campos de atraso, campos modernos: discursos da extensão rural em Santa Catarina (1956-1975)." Florianópolis, 1997. Dissertação (Mestrado em História) Curso de Pós Graduação em História, CFH, Universidade Federal de Santa Catarina/UFSC.

LOPES, Sérgio. O território do Iguaçu no contexto da Marcha para Oeste. Cascavel (PR): Edunioeste, 2002.

MACHADO, Paulo Pinheiro. "A política de terras em Santa Catarina: posse, propriedade e legitimação no Planalto Serrano e Meio-oeste no final do Império e início da República (18541912).” In: Anais do XXVI Simpósio Nacional de História. São Paulo: ANPUH, 2011.

Lideranças do Contestado: a formação e a atuação das chefias caboclas (1912-1916). Campinas (SP): Editora da Unicamp, 2004.

Política de colonização no Império. Porto Alegre: Ed. da Universidade/UFRGS, 1999.

MACHADO, Lia Osório. "Origens do Pensamento geográfico no Brasil: meio tropical, espaços vazios e a ideia de ordem (1870-1930)." In: CASTRO, Iná E. de (Org). Geografia: conceitos e temas. Rio de Janeiro: Bertrand Brasil, 1995. pp.309-353.

MAIA, João M. Ehlert. A terra como invenção: o espaço no pensamento social brasileiro. Rio de Janeiro: Jorge Zahar Ed, 2008.

MAMIGONIAN, Armen. "Vida regional em Santa Catarina." Revista Orientação - Instituto de Geografia da Universidade de São Paulo/IG USP, 1966. pp.35-38. 
Apresentação (Prefácio). In: SILVA, Célia Maria e. Ganchos (SC): ascensão e decadência da pequena produção mercantil pesqueira. Florianópolis: Ed.UFSC; Fundação Catarinense de Cultura/FCC, 1992. pp.15-17.

MAMIGONIAN, Beatriz Gallotti.; VIDAL, Josiane Z. (Org). História diversa: africanos e afrodescendente na Ilha de Santa Catarina. Florianópolis: Ed. Da UFSC, 2013.

MASSEY, Dorenn; KEYNES, Milton. "Filosofia e Política da espacialidade: algumas considerações.” Niterói (RJ) GEOgraphia, UFF Vol. 6, No 12 (2004), pp. 07-23.

MARTINELLO, André Souza. Insulares Santas Catarina: construção territorial, vínculos de pertencimentos e discursos da desintegração (1950-1970). Dissertação (Mestrado) em História, 2012. Florianópolis. Centro de Filosofia e Ciências Humanas/CFH, Universidade Federal de Santa Catarina/UFSC.

MAY, Patrícia Zumblick Santos. "Redes político-empresariais de Santa Catarina (1961-1970)." Dissertação (Mestrado) Curso de Pós Graduação em História, CFH, 1998 Universidade Federal de Santa Catarina/UFSC.

MEIRINHO, Jali. "A Designação Barriga-Verde". Revista da Academia catarinense de letras, $\mathrm{n}^{\circ} 21 . \mathrm{pp} .45-54$.

A república e oligarquias. Subsídios para a história catarinense (1889-1930). Florianópolis: ed. Insular, 1997.

MONTEIRO, Duglas T. Os errantes do novo século. Um estudo sobre o surto milinarista do Contestado. São Paulo: Editora da Universidade de São Paulo/Edusp, 2011.

MOSIMANN, João C. Catarinenses, gênese e história. Florianópolis: Ed. do autor, 2010.

Porto dos Patos. Florianópolis: Ed. do Autor, 2004.

MORAES, Antonio Carlos Robert. "Historicidade, Consciência e Construção do Espaço. Notas para um debate." Métodos em questão ( $\mathbf{n}^{\mathbf{0}}$ 18). Instituto de Geografia, Universidade de São Paulo, 1983. pp.01-14.

“Foucault e a Geografia.” In: TRONCA, Ítalo A. (org). Foucault Vivo. Campinas (SP): Pontes, 1987. pp.127-136.

"Foucault e a Geografia." In: AGB/Associação dos Geógrafos Brasileiros São Paulo. No66. $1^{\circ}$ Semestre de 1988. pp.129-135.

“A particularidade Histórica da Alemanha e a Gênese da Geografia Moderna.” In: A gênese da Geografia Moderna. São Paulo: Hucitec/Ed. da USP, 1989. pp.15-75 (cap.I).

"Notas sobre identidade nacional e institucionalização da Geografia no Brasil." Estudos Históricos vol.4, n 8. 1991. pp.166-176.

"Notas sobre a Formação Territorial e Políticas Ambientais no Brasil." Revista Território julho/dezembro 1999, UFRJ - Ano IV, nº7. pp.43-50. 
Bases da Formação Territorial do Brasil: o território colonial no 'longo do século XVI'. São Paulo: Hucitec, 2000a.

Capitalismo, Geografia e Meio Ambiente. Tese de Livre Docência em Geografia USP. Faculdade de Filosofia, Ciências e Letras/FFLCH, Geografia Humana. São Paulo, 2000b.

"Bases da Formação Territorial do Brasil." Revista Geografar, departamento de Geografia do Centro de Ciências Humanas e Naturais da Universidade do Espírito Santo/UFES. Vitória, no 2, junho de 2001. pp.105-113.

"Formação Territorial e Políticas Ambientais no Brasil." In: RIBEIRO, Wagner C. (Organizador). Patrimonio Ambiental Brasileiro. São Paulo: Ed. da USP; Imprensa Oficial do Estado de SP, 2003a. pp.79-87.

"El Sérton como el 'Otro' Geográfico.” In: BERTONCELLO, Rodolfo; CAROS, Ana Fani A. (organizadores). Processos Territoriales en Argentina y Brasil. Buenos Aires: Instituto de Geografia, Facultad de Filosofia y Letras, Universidade de Buenos Aires: 2003b. pp.45-58.

Território e História no Brasil. $2^{\mathrm{a} e d . ~ S a ̃ o ~ P a u l o: ~ A n n a b l u m e, ~ 2005 a . ~}$

Ideologias geográficas.5a ed. São Paulo: Annablume, 2005b.

"Território, poder e justiça: comentários a partir da experiência brasileira." In: KRITSCH, Raquel; RICUPERO, Bernardo. (Organizadores). Força e Legitimidade: novas perspectivas? São Paulo: Editorial Humanitas, 2005c. pp.113-129.

Geografia histórica do Brasil: cinco ensaios, uma proposta e uma crítica. São Paulo: Annablume, 2009.

"Nação e território: ideologias geográficas na formação histórica do Brasil." In: Instituto Prometheus de Estudos Ambientais, Culturais e Políticos; Fundação Lia Maria Aguiar. Fórum Rumos da Cidadania. São Paulo: Instituto Prometheus de Estudos Ambientais, Culturais e Políticos, 2010. pp. 59-72.

. "Geografia, interdisciplinaridade e metodologia." GeoUsp - Espaço e Tempo (On Line), São Paulo, v.18, n.1, p.09-39. 2014a.

Território em Milton Santos. São Paulo: Annablume, 2014b.

. ; COSTA, Wanderley M. da. Geografia Crítica, a valorização do espaço. São Paulo: Editora Hucitec, 1984.

. ; COSTA, Wanderley M. da. "A Geografia e o Processo de Valorização do Espaço.” In: SANTOS, Milton (organizador). Novos Rumos da Geografia Brasileira. $2^{\mathrm{a}}$ ed. São Paulo: Ed. Hucitec, 1988b. pp.111-130.

NOVAIS, Fernando. "Entrevista com Fernando Novais." In: PRADO JR, Caio. Formação do Brasil contemporâneo: colônia. Entrevista Fernando Novais; posfácio Bernardo Ricupero. $1^{\mathrm{a}}$ ed. São Paulo: Companhia das Letras, 2011. pp.401-418.

OLIVEN, Ruben George. A parte e todo: a diversidade cultural no Brasil-Nação. Petrópolis (RJ): Vozes, 1992. 
" "Á la recherche dês origines perdues. Le mouvement traditionaliste gaúhco au Brésil". Études Rurales $\mathbf{n}^{\mathbf{0}}$ 163-164, julliet-décembre 2002. Études des hautes études en scientes sociales. pp.145-166.

“Gilberto Freyre e a questão regional”. In: AXT, Günter; SCHÜLER, Fernando (Org). Intérpretes do Brasil. Porto Alegre: Artes e Ofícios, 2004. pp.192-201.

OLIVEIRA, Licério de. "'Estado do Iguaçu': o reginalismo em questão". Dissertação de Mestrado (Ciência Política) Instituto de Filosofia e Ciências Humanas da Universidade Estadual de Campinas IFCH/UNICAMP, 1999.

OLIVEIRA, Lúcia Lippi. Americanos: representação da identidade nacional no Brasil e nos EUA. Belo Horizonte: Ed.UFMG, 2000.

"A conquista do espaço: sertão e fronteira no pensamento brasileiro." História, Ciências, Saúde - Manguinhos, Rio de Janeiro, Vol.V (suplemento), pp.195-215, julho 1998.

OLIVEIRA, Ricardo de. "Euclides da Cunha, Os Sertões e a invenção de um Brasil profundo.". Revista brasileira de História, São Paulo, v.22, no 44, pp.511-537, 2002.

ORTIZ, Renato. Um outro território: ensaios sobre a mundialização. São Paulo: Editora Olho d'Água, 2005.

PEDRO, Joana Maria. "O Desenvolvimento da Construção Naval em Itajaí, Santa Catarina, uma resposta ao Mercado local, 1900 a 1950." Dissertação (Mestrado em História), 1979, UFSC, CFH. Programa de Pós-Graduação em História. Florianópolis.

. "Mulheres do Sul". In: DEL PRIORI, Mary (Org). História das mulheres. São Paulo: Ed. Contexto. 1997. pp.278-321

PELUSO JÚNIOR, Victor Antônio. Aspectos geográficos de Santa Catarina. Florianópolis: Fundação Catarinense de Cultura/FCC; Editora da UFSC, 1991.

PIAZZA, Walter Fernando. "Elementos básicos da história catarinense." In: CORREA, Carlos Humberto (Org). Fundamentos da Cultura Catarinense. Rio de Janeiro: editora Laudes, 1970. pp. 21-48.

"A frente pioneira do século XX". Revista Blumenau em Cadernos tomo XIV setembro de 1978, $\mathbf{n}^{\circ}$ 9. Blumenau/SC. pp.169-174

(organizador). Dicionário Político Catarinense. Florianópolis: Assembléia Legislativa de Santa Catarina, 1994.

“A ocupação do território catarinense." In: IHGSC/Instituto Histórico e Geográfico de Santa Catarina. A realidade catarinense no século XX. Florianópolis: IHGSC, 2000. pp.25-39.

PICCOLO, Helga Iracema L. "O processo de independência numa região fronteiriça: o Rio Grande de São Pedro entre duas formações históricas." In: JANCSO, Istvan. (Org). Independência: História e Historiografia. São Paulo: Editora da Hucitec; Fepesp; Edusp, 2005. pp.577-613.

POUTIGNAT, Philippe; STREIFF-FENART, Jocelyne. Teorias da etnicidade. Seguido de Grupos étnicos e suas fronteiras de Fredrik Barth. São Paulo: Editora da UNESP, 1998. 
PRADO JUNIOR, Caio. “A formação dos limites meridionais do Brasil.” In:_. Evolução política do Brasil e outros estudos. São Paulo: Companhia das Letras, 2012. pp.157-173.

QUAINI, Massimo. "As Cidades Invisíveis de Ítalo Calvino: uma lição de Geografia." In: SAQUET, Marcos A.; SPOSITO, Eliseu A. (organizadores). Territórios e Territorialidades: teorias, processos e conflitos. São Paulo: Expressão Popular; UNESP/Programa de PósGraduação em Geografia. 2009, pp.121-141.

RAFFESTIN, Claude. "A Produção das Estruturas Territoriais e sua Representação." In: SAQUET, Marcos A.; SPOSITO, Eliseu A. (organizadores). Territórios e Territorialidades: teorias, processos e conflitos. São Paulo: Expressão Popular; UNESP/Programa de PósGraduação em Geografia. 2009, pp.17-35.

RAUD, Cécile. Indústria, território e meio ambiente no Brasil: perspectivas da industrialização descentralizada a partir da experiência catarinense. Florianópolis: Editora da UFSC; Blumenau: Ed. da FURB, 1999.

REIS FILHO, Nestor Goulart. "Algumas experiências urbanísticas do início da República: 1890-1920.” CADERNOS DE PESQUISA DO LAP, agosto de 1994, nº1.

RENAUX HERING, Maria Luiza. Colonização e indústria no vale do Itajaí: o Modelo Catarinense de Desenvolvimento. Blumenau (SC): Editora da FURB, 1987.

RENK, Arlene. Narrativas da diferença. Chapecó (SC): Argos, 2004.

"O conhecimento do território: a Bandeira de Konder." In: CEOM/Centro de Memória do Oeste de Santa Catarina (Org.) A viagem de 1929: Oeste de Santa Catarina, documentos e leituras. Chapecó: Argos, 2005. pp. 109-127.

“A ocupação do Oeste catarinense." In:__. A luta da erva. Um ofício étnico da nação brasileira no oeste catarinense. $2^{\text {a }}$ ed. Chapecó: Ed. Argos, 2006. pp.31-61 (capp.01).

RICUPERO, Rubens. Rio Branco: o Brasil no mundo. Rio de Janeiro: Ed. Contraponto, 2000.

ROSSATO, Luciana. A lupa e o diário. História natural, viagens cientificas e relatos sobre a capitania de Santa Catarina 1763-1822. Itajaí (SC): Ed. da Univale, 2007.

SACHET, Celestino; Sérgio SACHET. Santa Catarina, 100 anos de história. Livro I. Florianópolis: Século Catarinense/RBS TV, 1997.

SAINT-EXUPÉRY, Antoine de. O Pequeno Príncipe. Com aquarelas do autor. Rio de Janeiro: Agir, 2009.

Le Petit Prince. Luçon: Folie Junior. 2009.

SALOMON, Marlon. "O saber do espaço. Ensaio sobre a geografização do espaço em Santa Catarina no século XIX." Universidade Federal de Santa Catarina/UFSC, Centro de Filosofia e Ciências Humanas/CFH, Tese Doutorado em História, 2002. Florianópolis,

SANTOS, Luís C. V. Gomes. O evangelho do Barão. Rio Branco e a identidade brasilleira. São Paulo: Ed. UNESP, 2012.

SANTOS, Milton. La Nature de L'Espace. Technique et temps, raison et emotion. Traduit par Marie Hélène Tiercelin. Paris: L’Harmattan, 1997. 
Por uma Geografia Nova: Da Crítica da Geografia a uma Geografia Crítica." São Paulo: Editora da Universidade de São Paulo, 2002.

Metamorfoses do espaço habitado. São Paulo: Hucitec, 1997.

.; SILVEIRA, Maria Laura. O Brasil: território e sociedade no início do século XXI. $6^{\mathrm{a}}$ ed. Rio de Janeiro: Record, 2004.

SANTOS, Gislene A. dos. "Estado, Redes Sociais e Fronteira: a migração do sul catarinense para os Estados Unidos.” Tese (Doutorado em Geografia), UFSC. Florianópolis, 2007.

SECCO, Lincoln. Caio Prado Júnior, o sentido da revolução. São Paulo: Boitempo, 2008.

Caio Prado Júnior: Geógrafo.Anais do II Encontro Nacional de História do Pensamento Geográfico. pp.293-306

SERPA, Élio Cantalício. "A identidade catarinense nos discursos do Instituto Histórico e Geográfico de Santa Catarina." Revista de Ciências Humanas, UFSC/CFH. V.14, n.20. Florianópolis, 1996. pp.63-79.

SEYFERTH, Giralda. "Colonização européia, campesinato e diferenciação cultural no Vale do Itajaí (SC).” In: GODOI, Emilia Pietrafesa de; MENEZES, Marilda Aparecida de; MARIN, Rosa Acevedo (Orgs). "Diversidade do campesinato: expressões e categorias. Construções identitárias e sociabilidades", vol 01. 2009, pp.275-295.

SILVA, Etienne Luiz. "Desenvolvimento econômico periférico e formação da rede urbana de Santa Catarina." Dissertação (Mestrado) em Planejamento Urbano e Regional. Universidade Federal do Rio Grande do Sul/UFRGS, Porto Alegre, junho de 1978.

SILVA, Augusto da. A Ilha de Santa Catarina e sua Terra firme. Estudo sobre o governo de uma capitania subalterna (1738-1807). Tese (doutorado) em História Econômica, FFCLH/Faculdade de Filosofia, Letras e Ciências Humanas da Universidade de São Paulo/USP. 2008.

O governo da Ilha de Santa Catarina e sua terra firme: território, administração e sociedade (1738-1807(. Rio de Janeiro: Arquivo Nacional, 2013.

SILVA, Daniel Afonso da. O enigma da capital. A mudança do vice-reino para o Rio de Janeiro em 1763. Tese (Doutorado) em História Social, FFLCH, USP, 2012. São Paulo.

SINGER, Paul. "Blumenau". In: _. Desenvolvimento e evolução urbana: análise da evolução econômica de São Paulo, Blumenau, Porto Alegre, Belo Horizonte e Recife. São Paulo: Editora Nacional e Editora da USP, 1968. pp.81-140.

SOUZA, Marcelo J. Lopes de. “'Território' da Divergência (e da confusão): em torno das imprecisas fronteiras de um conceito fundamental." In: SAQUET, M. A.; SPOSITO, E. S. (Orgs). Território e territorialidades: teorias, processos e conflitos. São Paulo: Ed. Expressão Popular; Programa de Pós-Graduação em Geografia/UNESP, 2009. pp.57-72. (cap.03).

'Espaciologia': uma objeção (crítica aos prestigiamentos pseudo-críticos do espaço social). Revista Terra livre n.5 ('O espaço em questão'). São Paulo: Associação dos Geógrafos brasileiros-AGB, 1988.

TOPIK, Steven C. COMÉRCIO E CANHONEIRAS. Brasil e Estados Unidos na Era dos Impérios (1889-97). Trad. Ângela Pessoa. São Paulo: Companhia das Letras, 2009. 
VALVERDE, Orlando. Planalto Meridional do Brasil. Guia da excursão nº, realizada por ocasião do XVIII Congresso Internacional de Geografia. Rio de Janeiro: Conselho Nacional de Geografia, 1957.

VASCONCELOS, Pedro de A. "Les agents de La formation dês Villes coloniales bresiliennes." In: DIAS, Leila Christina; RAUD, Cécile (Org). Villes e Régions au Brésil. Paris: L'Harmattan, 2000. pp.79-92.

VIEIRA FILHO, Dalmo. Santa Catarina 500 anos: terra do Brasil. Florianópolis: A Notícia, 2001.

VIEIRA, Paulo F.; BERKES, F.; SEIXAS, C. S. (Orgs). Gestão integrada e participativa de recursos naturais: conceitos, métodos e experiências. Florianópolis: SECCO-Aped, 2005.

WEBER, Max. Ciência Política duas vocações. São Paulo: Ed. Cutrix, 2004.

WITTMANN, Luisa Tombini. O vapor e o botoque: imigrantes alemães e índios Xokleng no Vale do Itajaí/SC (1850-1926). Florianópolis: Letras Contemporâneas, 2007.

Zilly, Bertthold. "A guerra como painel e espetáculo: a história encenada em 'Os Sertões'." In: História, Ciências, Saúde: Manguinhos, vol. V, julho de 1998, p. 13-37. 


\section{ANEXOS}

http://www2.camara.gov.br/legin/fed/decret/1910-1919/decreto-3304-3-agosto-1917-572722-publicacaooriginal-96000-pl.html

\section{Legislação Informatizada - Decreto no 3.304, de 3 de Agosto de 1917 - Publicação Original}

EMENTA: Publica a resolução do Congresso Nacional que approva o accôrdo de 20 de outubro de 1916, firmando entre os Estados do Paraná e Santa Catharina, estabelecendo os seus limites.

\section{Decreto no 3.304, de 3 de Agosto de 1917}

Publica a resolução do Congresso Nacional que approva o accôrdo de 20 de outubro de 1916, firmando entre os Estados do Paraná e Santa Catharina, estabelecendo os seus limites.

O Presidente da Republica dos Estados Unidos do Brasil:

Faço saber que o Congresso Nacional resolveu approvar a resolução seguinte:

Art. $1^{\circ}$ Nos termos do accôrdo de 20 de outubro de 1916, firmado entre os Estados do Paraná e Santa Catharina, approvado pela lei n. 1.146, de 6 de março de 1917, deste, e lei n. 1.653, de 23 de fevereiro de 1917, daquelle, os limites entre os mesmos Estados passam a ser os seguintes:

No littoral: entre o Oceano Atlantico e o rio Negro, a linha divisoria que tem sido reconhecida pelos dous Estados desde 1771;

No Interior: o rio Negro, desde as suas cabeceiras até á sua fóz no rio Iguassú, e por este até á ponte da Estrada de Ferro S. Paulo-Rio Grande; pelos eixos desta ponte e da mesma estrada de ferro até á sua intercepção com o eixo da estrada de rodagem que actualmente liga a cidade de União da Victoria á cidade de Palmas; pelo eixo da referida estrada de rodagem até o seu encontro com o rio Jangada; por este acima até ás suas cabeceiras, e dahi em linha recta na direcção do meridiano, até á sua intercepção com a linha divisoria das aguas dos rio Iguassú e Uruguay, e por esta linha divisoria das ditas aguas na direcção geral do Oéste até encontrar a linha que liga as cabeceiras dos rios Santo Antonio e Pepiry-guassú, na fronteira argentina.

Art. $2^{\circ}$ Revogam-se as disposições em contrario.

Rio de Janeiro, 3 de agosto de $1917,96^{\circ}$ da Independencia e $29^{\circ}$ da Republica.

WENCESLAU BRAZ P. GOMES

Carlos Maximiliano Pereira dos Santos

Este texto não substitui o original publicado no Diário Oficial da União - Seção 1 de 04/08/1917

Publicação:

- Diário Oficial da União - Seção 1 - 4/8/1917, Página 8153 (Publicação Original) 


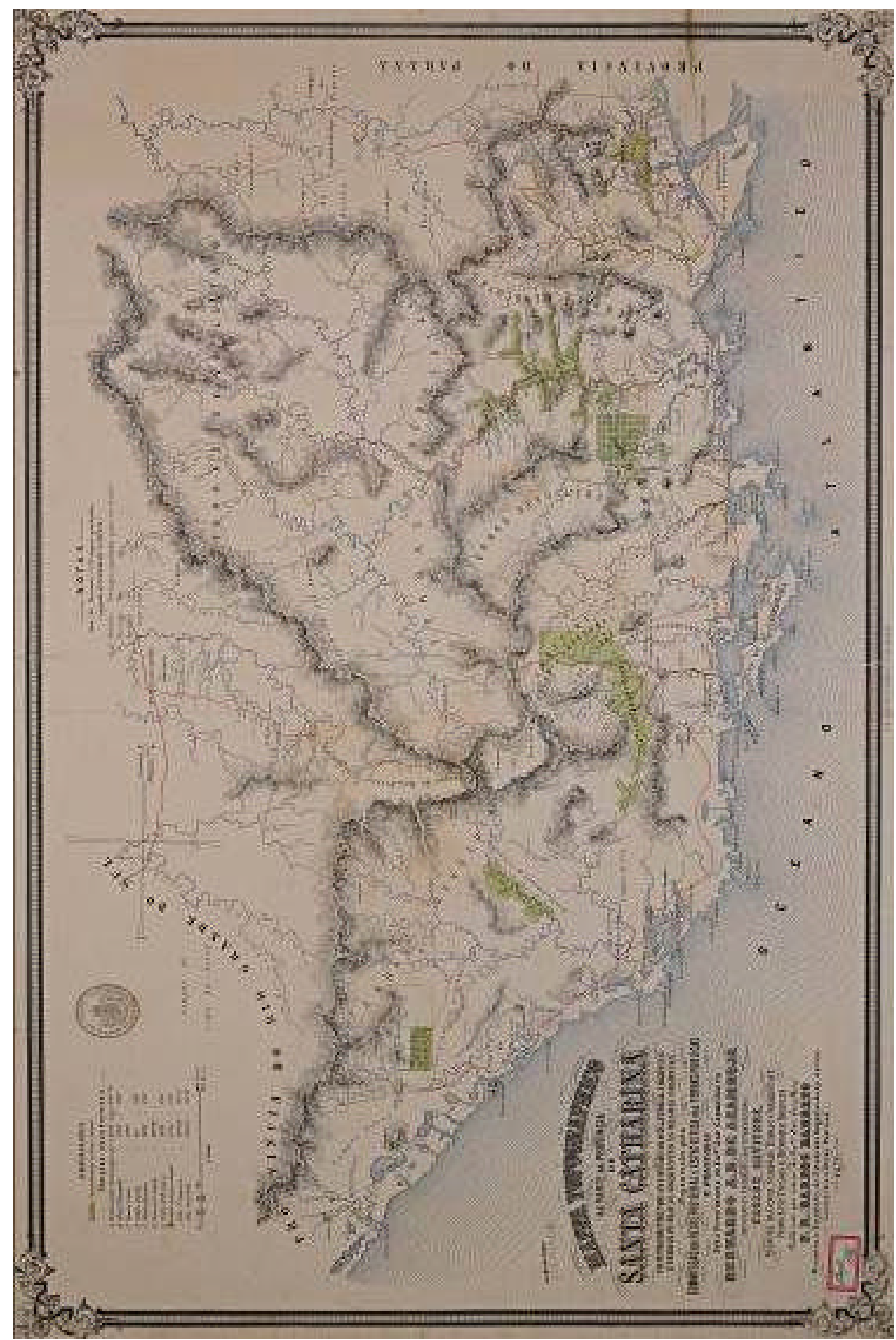

